UNIVERSIDADE DE SÃO PAULO

FACULDADE DE FILOSOFIA, LETRAS E CIÊNCIAS HUMANAS DEPARTAMENTO DE HISTÓRIA

PROGRAMA DE PÓS-GRADUAÇÃO EM HISTÓRIA SOCIAL

FABIANA PEDRONI FAVORETO

A ORQUESTRAÇÃO DO ORNAMENTO NO BEATUS DE FACUNDUS

SÃO PAULO

2016 


\author{
UNIVERSIDADE DE SÃO PAULO \\ FACULDADE DE FILOSOFIA, LETRAS E CIÊNCIAS HUMANAS \\ DEPARTAMENTO DE HISTÓRIA \\ PROGRAMA DE PÓS-GRADUAÇÃO EM HISTÓRIA SOCIAL
}

\title{
A ORQUESTRAÇÃO DO ORNAMENTO NO BEATUS DE FACUNDUS
}

Fabiana Pedroni Favoreto

Dissertação apresentada ao Programa de PósGraduação em História Social do Departamento de História da Faculdade de Filosofia, Letras e Ciências Humanas da Universidade de São Paulo para a obtenção do título de Mestre.

Orientadora: Profa. Dra. Maria Cristina Correia Leandro Pereira 
Autorizo a reprodução e divulgação total ou parcial deste trabalho, por qualquer meio convencional ou eletrônico, para fins de estudo e pesquisa, desde que citada a fonte.

Catalogação na Publicação

Serviço de Biblioteca e Documentação

Faculdade de Filosofia, Letras e Ciências Humanas da Universidade de São Paulo

F2750 Favoreto, Fabiana Pedroni
A orquestração do ornamento no Beatus de Facundus / Fabiana Pedroni Favoreto ; orientadora Maria Cristina Correia Leandro Pereira. - São Paulo, 2016. $199 \mathrm{f}$.

Dissertação (Mestrado) - Faculdade de Filosofia, Letras e Ciências Humanas da Universidade de São Paulo. Departamento de História. Área de concentração: História Social.

1. Ornamento. 2. Beatus de Facundus. 3. Imagem medieval. 4. Cor. 5. Orquestração. I. Pereira, Maria Cristina Correia Leandro, orient. II. Título. 
Dedicado a Dionísio, Mizu, Momiji e Pingo, por darem vários sentidos à palavra "fofura".

Dedicado também a Chewie e a sua curiosidade quanto ao gosto dos livros. 


\section{AGRADECIMENTOS}

A concretização deste trabalho não seria possível sem a colaboração, voluntária ou não, daqueles que me cercam.

Agradeço aos integrantes do Laboratório de Teoria da Imagem e da Música Medievais (LATHIMM- USP), coordenado pelos professores Eduardo Henrik Aubert, Maria Cristina Correia Leandro Pereira, Rita Luciana Berti Bredariolli e Gabriel Castanho, por todos os diálogos, leitura de textos, discussões, acadêmicas ou não, que deram corpo e acolhimento ao trabalho. A estes amigos, agradeço especialmente as risadas, porque não há trabalho gratificante sem divertimento.

Agradeço a Doglas Morais Lubarino, por tornar este trabalho mais leve nas horas de preocupação, por poder dividir com ele o peso burocrático que uma dissertação exige. Uma amizade regada a muita paciência, amor e chás de camomila.

Agradeço especialmente à paciência de minha mãe e as conversas supostamente sem sentido com minha avó. No momento da escrita é que mais absorvemos os diálogos e as vivências para a construção teórica. Muitos trechos do trabalho foram escritos sob o pensamento de convivências familiares, depois de ouvir frases "alzheimerianas", como "Plantei um tomateiro dentro desta caixa, mas não conta pra ninguém" e "Tem um pato comendo fogos debaixo da cama".

Agradeço a Rodrigo Hipólito por me inspirar sobre o peso conceitual e poético em cada vivência. Por me mostrar que tudo pode ser uma construção, a qual será mais prazerosa quando vista e escrita segundo o mesmo coração, talvez um coração literário. Agradeço também por todas as leituras, revisões e discussões sobre o trabalho, este que nunca termina.

Lembro também de todos que compreenderam meu recolhimento temporário, especialmente Ana Cristina Motta, que ocupa o primeiro item da lista "Depois da dissertação".

Agradeço à Capes, pelo financiamento da pesquisa. 
E me disse: toma [o livro] e devora-o, quer dizer, mete-o dentro de suas entranhas e escreva-o na largura de seu coração.

Beato de Liébana. 


\section{RESUMO}

A partir do estudo das imagens do Beatus de Facundus, manuscrito produzido em Leão e Castela no século XI, esta dissertação trata do poder do ornamento de tomar posse da matéria da imagem e a fazer funcionar segundo sua ordenação. Distanciamos o conceito de ornamento da redução a um elemento decorativo, para restituir-lhe a potencialidade funcional presente em sua origem etimológica nos termos de ornamentum e kosmos. O ornamento assume diversas funções além de uma decoração honorífica. Ele trabalha associado ao símbolo, à iconografia, à memória e aos elementos composicionais da imagem ao exercer funções moduladora e estrutural. Seu trabalho torna a imagem uma máquina, um corpo material complexo e funcional. O ornamento é uma beleza honorífica que pode ser assumida por qualquer elemento composicional, desde os mais figurativos aos mais abstratos, como as cores. Com respaldo nos conceitos, sobretudo, de imago, figura (Didi-Huberman), imagemobjeto (Jérôme Baschet), ornamental e ornamentalidade (Jean-Claude Bonne), abordamos o ornamento, no Beatus de Facundus, como um elemento que gere uma estrutura dialógica através de seu poder de orquestração. Desse modo, este estudo constitui um esforço de circunscrever um livro e lhe permitir mostrar seu corpo e seu trabalho através de suas próprias ferramentas.

Palavras-chave: Ornamento. Beatus de Facundus. Imagem medieval. Cor. Orquestração. 


\begin{abstract}
From the study of images of Beatus of Facundus, that is a manuscript produced in the kingdom of Castile and Leon, in the eleventh century, this dissertation deals with the "power of the ornament" to take hold of the material of image and to make it work according to their ordination. We distance the concept of ornament from the reduction to a decorative element, to restore his functional potentiality, that is present in his etymological origin, in the terms of ornamentum and kosmos. The ornament takes many functions besides an honorific decoration. It works associated with the symbol, the iconography, the memory and the compositional elements of the image by exercising modulating and structural functions. Its work turns the image into a machine, a complex and functional material body. The ornament is an honorific beauty that can be assumed by any compositional element, from the more figurative to more abstract, like the colors. With endorsement of some concepts, especially of imago, figure (Didi-Huberman), image-object (Jérôme Baschet), ornamental and ornamentality (Jean-Claude Bonne), we approach the ornament, in the Beatus of Facundus, as an element that generates a dialogic structure through its power of orchestration. In this manner, this study constitutes an effort to circumscribe a book and allow it to show its body and its work through its own tools.
\end{abstract}

Keywords: Ornament. Beatus of Facundus. Ornamentality. Color. Orchestration. 


\section{LISTA DE FIGURAS}

Figura 1. Volumen em papiro.

Figura 2. Bifólios 31

Figura 3. Processo de Picotagem 31

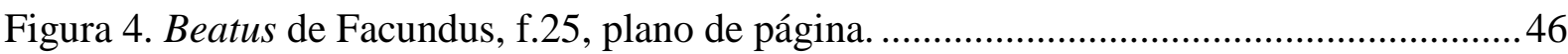

Figura 5. Beatus de Facundus, plano de página (Williams)..................................................47

Figura 6. Beatus de Facundus, ff. 7v-8, ciclo dos evangelistas...........................................52

Figura 7. Beatus de Facundus, ff. 8v-9, ciclo dos evangelistas............................................52

Figura 8. Beatus de Facundus, ff. 9v-10, ciclo dos evangelistas............................................53

Figura 9. Formação do caderno 33 do Beatus de Facundus. ....................................................57

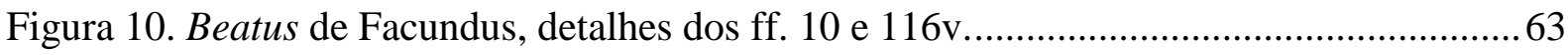

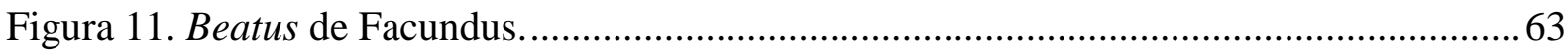

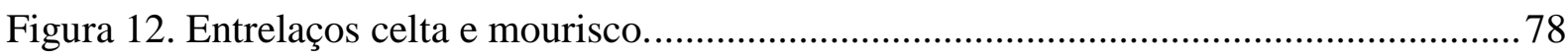

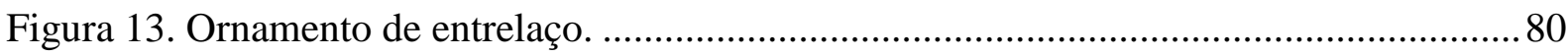

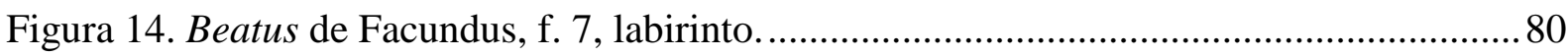

Figura 15. Detalhe do f. 7, letra F (Fredenandus) e ornamento em ouro............................... 84

Figura 16. Beatus de Facundus, f. 7, canto superior esquerdo. ........................................... 86

Figura 17. Beatus de Facundus, detalhe f. 7, canto superior direito....................................... 86

Figura 18. Beatus de Facundus, detalhe f. 7, canto inferior direito........................................8 87

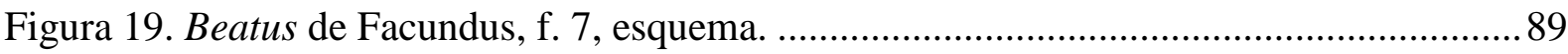

Figura 20. Beatus de Facundus. Figuração de nuvens......................................................... 110

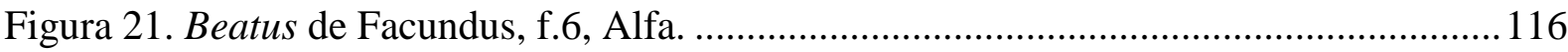

Figura 22. Diurnal de Fernando I e Sancha, f. 1, Alfa. ....................................................... 118

Figura 23. Princípios de varietas nos Beati....................................................................... 120

Figura 24. Sistema de blocos, ff. 78, 82v, 87v, 92, 96, 100v e 106v. ................................ 123 


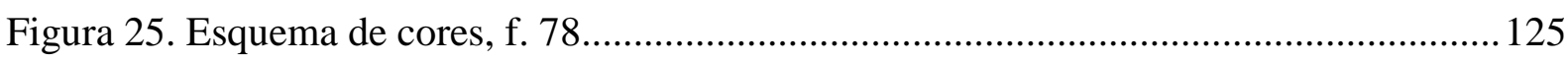

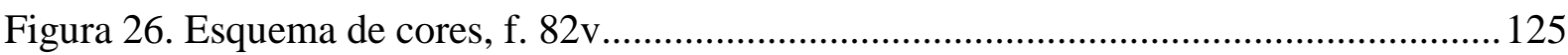

Figura 27. Esquema de cores, f. 87v

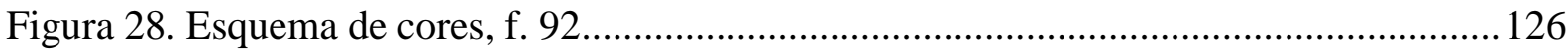

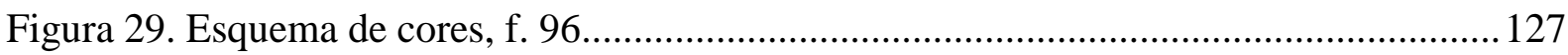

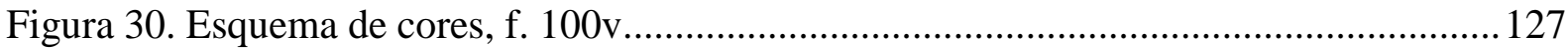

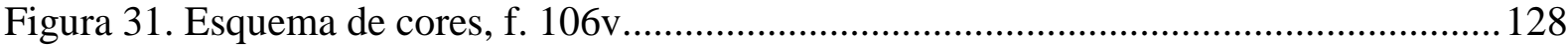

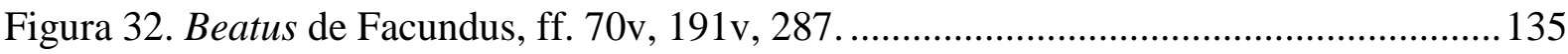

Figura 33. Beatus de Facundus, f. 191v, detalhes de ornamento. ........................................ 135

Figura 34. Beatus de Liébana, ff. 233v-234, Queda da Babilônia. ........................................139

Figura 35. Beatus de Facundus, ff. 268v-269, Cerco a Jerusalém. ....................................... 139

Figura 36. Beatus de Facundus, f. 109, Arca de Noé. …....................................................... 145

Figura 37. Beatus de Facundus, f. 253v, A Jerusalém celeste que desce do céu. .................. 148

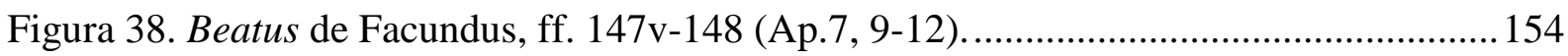

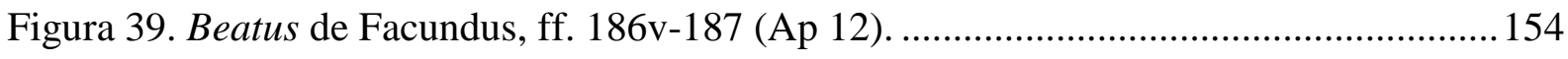

Figura 40. Beatus de Facundus, ff. 250v-251 (Ap 20, 11-15)......................................... 155

Figura 41. Esquema de ressonâncias e prefigurações........................................................ 156

Figura 42. Beatus de Facundus, detalhes ff. 30, 267, títulos............................................. 163

Figura 43. Beatus de Facundus, detalhes ff. 162, 108v, titulos........................................... 164 


\section{LISTA DE QUADROS}

Quadro 1. Beatus de Facundus, formação dos cadernos.

Quadro 2. Beatus de Facundus, sequência de imagens iniciais e conteúdo textual. 58

Quadro 3. Varietas. Bandas de cor. 128

Quadro 4. Varietas. Livros. 129

Quadro 5. Varietas. Asas do anjo e interior da igreja..... 130 


\section{SUMÁRIO}

1 A IMAGEM MEDIEVAL NO ORGANISMO MANUSCRITO ..................................11

2 AS CAMADAS DA IMAGEM OU POR QUE LIVROS PRECISAM DE

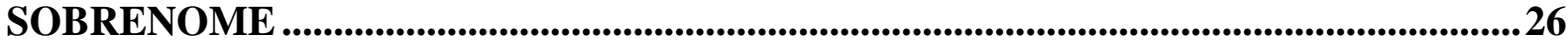

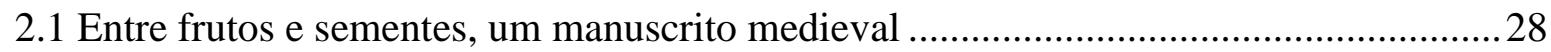

2.2 Sobre a germinação: como determinar uma família de manuscritos ............................. 35

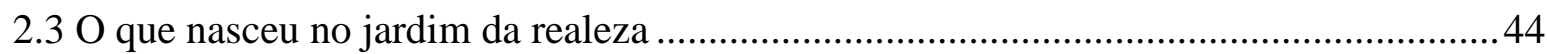

3 COMO ABRAÇAR UMA MÁQUINA: O ORNAMENTO COMO ENGRENAGEM

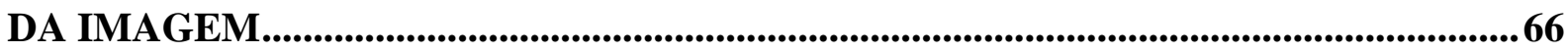

3.1 Forma, função e o conceito de ornamental e ornamentalidade ................................... 77

4 UMA SUTIL ECONOMIA DAS CORES ............................................................................104

5 A ORQUESTRAÇÃO DO FIM DO MUNDO...................................................140

6 CONSIDERAÇÕES DO FIM EM ETERNO ACONTECIMENTO .........................167

7 REFERÊNCIAS ..............................................................................................................170

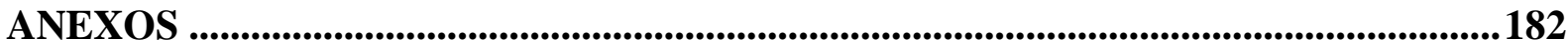

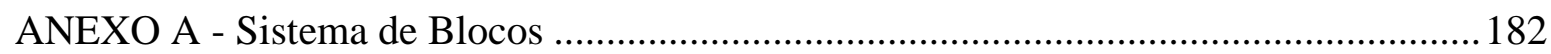

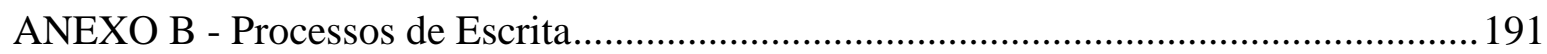

ANEXO C - Relação de Beati e stemma codicum.............................................................. 194 


\section{A IMAGEM MEDIEVAL NO ORGANISMO MANUSCRITO}

Quando um livro começa? Alguns dirão que na concepção do escritor (ideia). Outros dirão que começa na primeira página do texto (conteúdo). Talvez o livro comece na própria textura da encadernação (matéria) ou mesmo na história que um livro, já empoeirado, carrega (memória). Não faltam relatos de bibliófilos sobre o primeiro encontro com um livro marcante. ${ }^{1}$ Aquele momento de encostar os dedos sobre a textura áspera da página, a delicadeza e estilização do corte da folha, tudo que intensifica a vivência da leitura, indicam uma experiência particular, em que cada um desenvolve seu próprio modo de ler. $\mathrm{Na}$ particularidade, todos convergem para uma ação em comum: folhear as páginas. Procura-se o índice, observa-se o conteúdo, leem-se frases aleatórias para sentir o ritmo da escrita/leitura, observam-se as imagens, caso as possua, o tamanho dos capítulos... Alguns chegam a dados mais específicos, como os espaçamentos, a forma dos caracteres tipográficos, o local da paginação.

Então começa a "leitura". Página por página, do primeiro ao último capítulo, ou de modo aleatório (outros nem se importarão tanto com a leitura, bastará admirá-los em sua biblioteca particular). ${ }^{2}$ Mas como seria essa experiência se o livro pesasse mais de 20 quilos? E se ele fosse muito pequeno, pouco maior que um dedal? Ou mesmo, se ele não possuísse elementos pré-textuais, como capa e sumário? Livros podem ser pouco parecidos com a ideia geral sobre livros. Como compreender um objeto com tantas possibilidades formais, mas que quase sempre se encontra cerceado por uma concepção tradicional muito bem determinada? As características materiais, aqui impossíveis de serem citadas em sua totalidade, influem diretamente no modo de leitura, e podem até indicar que determinado livro, na verdade, não é para ser lido.

As relações entre as características de um objeto e seu uso podem se tornar ainda mais complexas quando acrescentamos um dado temporal: não estamos diante da primeira edição

\footnotetext{
${ }^{1}$ Dentre muitos, ver SÁNCHEZ MARIANA, Manuel. Bibliófilos españoles desde sus orígenes hasta los albores del siglo XX. Madrid: Ollero e Ramos, 1993; MINDLIN, José. Uma vida entre livros: reencontros com o tempo. São Paulo: Universidade de São Paulo, 2008; FADIMAN, Anne. Ex-libris: confissões de uma leitora comum. Rio de Janeiro: Jorge Zahar, 2002.

${ }^{2}$ ECO, Umberto. A memória vegetal: e outros escritos sobre bibliofilia. Rio de Janeiro: Record, 2010.
} 
de "A metamorfose", de Franz Kafka (1915), nem de um livro de artista da década de $1950 .^{3}$ O livro que aqui se põe a nossa frente é um manuscrito medieval. Essa sentença modifica não apenas a materialidade do objeto, como também sua circulação, manuseio, conteúdo e vários outros pontos de reflexão que podem ser gerados sobre ele. A imagem mental que criamos já não é de um livro ao qual estamos habituados, não se trata de um conjunto de folhas de papel, reunidas por uma encadernação com cola, ou mesmo de costura, com uma série de caracteres tipográficos impressos.

Ser um manuscrito medieval implica, primeiramente, como indica o próprio nome, ser inteiramente escrito à mão (do latim manu scriptus). O fazer manual envolve outros tipos de ferramentas e materiais que não são próprios à tipografia. Pode-se falar, por exemplo, de pergaminho ao invés de papel, de pigmentos e aglutinantes de origem vegetal, animal ou mineral, muito diferentes e distantes das tintas de impressão. ${ }^{4}$ Cada traço será sempre o primeiro e único, mesmo quando se tratar de uma cópia. Algumas editoras, como a Moleiro, ${ }^{5}$ dedicam-se a feitura de fac-símiles de manuscritos medievais, livros impressos fotomecanicamente que reproduzem o mais fielmente possível o original. A técnica de reprodução é visualmente apurada, copia as características visíveis da obra original, desde o conteúdo textual e imagético, de mesmo tamanho que o modelo, até a vivacidade das cores, o uso de folhas de ouro, marcas de envelhecimento e irregularidades. Outras edições de luxo serão trabalhos de cópia estritamente manual, mas a pigmentação ainda sofre com a diferença material e a ação do tempo. Podemos fazer cópias de manuscritos medievais, mas eles ainda não serão, obviamente, medievais.

Nosso segundo ponto de consideração para a identificação básica de um livro como manuscrito medieval é sua localização no que historicamente compreendemos por Idade Média. Não vamos nos aprofundar na discussão sobre o que se define como Idade Média,

\footnotetext{
${ }^{3}$ O contraponto que propomos, entre a obra de Kafka e um livro de artista da década de 1950, serve bem para destacar a distância entre um livro de literatura, destinado a uma leitura mais convencional, de um livro que requer um "manuseio expressivo" por parte do leitor, como os livros-poemas de Ferreira Gullar, os trabalhos de Theon Spanudis, Lygia Pape, entre outros. Estes livros-poemas, e outros livros de artistas, que no Brasil surgiram após a década de 1950, exploram a relação do sujeito com as formas e evidenciam que a experiência perceptiva da leitura nem sempre se restringe ao olhar.

${ }^{4}$ No capítulo "As camadas da imagem ou Por que livros precisam de sobrenome" falaremos mais sobre as características materiais que compõem um manuscrito medieval. Por ora, observamos que a noção de livro não é unívoca. Mesmo quando determinamos a especificidade de um livro como manuscrito medieval, ainda não é possível fazer uma afirmação certeira sobre sua materialidade mais básica. Seria ele feito de pergaminho, papiro ou papel? Seu formato é em rolo ou códice? Essas perguntas devem ser postas, por mais evidentes que possam parecer à primeira vista.

${ }^{5}<$ http://www.moleiro.com/>
} 
principalmente quanto à sua duração, mas vale ressaltar que a compreensão do medievo como um conceito que não se delimita por fronteiras temporais rígidas é o que permite pensar a Idade Média não como um período, cercado em seus extremos por dois acontecimentos marcantes, nem como um conjunto homogêneo. ${ }^{6}$ Pensamos o medievo mais como um lugar (ou lugares), localizado temporalmente de modo mais complexo que uma duração de mil anos. Separamos o que nos é útil como ferramenta didática, na atribuição de nomes às produções relativamente diferentes, como dizer "isto é um manuscrito carolíngio", "isto é um manuscrito românico" e "isto é um manuscrito moçárabe", mas temos sempre em mente que essas denominações não esvaziam as multiplicidades formais e funcionais de cada produção.

Trabalhar com documentos medievais implica pensar em ferramentas que, apesar de localizadas em nosso tempo, pois partem de nossa experiência como pesquisadores (nossa própria localização temporal), não temem o anacronismo. A cautela é necessária, até para que se possa refletir sobre a distância que separa o pesquisador do seu objeto de pesquisa. $\mathrm{O}$ temor, este sim, deve ser evitado. Não podemos nos sentir ameaçados por essa distância, a ela não deve ser aderida um caráter negativo (bloqueador), nem mesmo positivo - este destinado especialmente aos ceticistas, que na impossibilidade de acessar plenamente o passado, desistem dele. A distância existe e precisa ser considerada em cada estudo, para que não busquemos inutilmente uma verdade absoluta. A distância não anula a viabilidade do estudo do passado, mas evidencia o trabalho do pesquisador como um construtor. ${ }^{7}$ A distância destitui do termo "invenção" o sentido pejorativo de falsidade, mentira, para restituir-lhe a ideia de construção e de "inventário", um armazenamento em constante reformulação. "Invenção" e "inventário" são dois termos originados da palavra latina inventio. ${ }^{8}$ Juntamos e $^{-}$ organizamos documentos para pensá-los de determinada maneira.

\footnotetext{
${ }^{6}$ Para uma discussão inicial do que seria a Idade Média, sobre as primeiras referências do termo na historiografia, conferir os artigos de Christian Amalvi, "Idade Média", e de Alain Guerreau, "Feudalismo", ambos em: LE GOFF, Jacques; SCHMITT, Jean-Claude. Dicionário temático do Ocidente medieval. Vol. I. Bauru/São Paulo: EDUSC/Imprensa Oficial, 2002, p. 537-551; p. 437-455. Ver também a bibliografia citada por esses autores. Sobre a longa duração da Idade Média, conferir LE GOFF, Jacques. Uma longa Idade Média. Rio de Janeiro: Civilização Brasileira, 2008.

${ }^{7}$ Sobre a história e sua relação com a ideia de construção e ficção, engendradas a partir da fundação dos Annales, ver PESAVENTO, Sandra Jatahy. Fronteiras da ficção. Diálogos da história com a literatura. Revista de História das Ideias, Coimbra, v. 21, p. 33-57, 2000.

${ }^{8}$ Como variação da palavra latina inventio tem-se a "invenção" (criação de algo novo, ou pelo menos diferente) e o "inventário" (armazenamento de muitos materiais diferentes). Segundo Mary Carruthers, este armazenamento é ordenado e não aleatório: [...] roupas jogadas no fundo de um armário não podem ser chamadas de "inventariadas". Um inventário deve ter uma ordem. Os materiais inventariados são contados e dispostos em locais dentro de uma estrutura global que permite que qualquer item seja recuperado de maneira fácil e rápida. [...] Ter um “inventário" é uma condição para a "invenção". Tal afirmação pressupõe não apenas
} 
Aqueles que pensaram a Idade Média como um período cronologicamente localizado entre a queda do Império Romano do Ocidente, em 476, e o século XV, não estavam errados. Suas construções sobre a história medieval pertenciam ao tempo daqueles pesquisadores e estavam rodeadas pelas discussões vigentes, pelos modos de se pensar a distância, o tempo, o passado e o presente. Poderíamos considerar como errônea a atitude reprodutiva dessas concepções em estudos atuais, em ignorância de todas as discussões sobre a duração da Idade Média e das próprias concepções de História engendradas desde o início do século XX e ainda em discussão no XXI. Talvez as nossas construções sejam consideradas errôneas em um tempo futuro, contudo, a consciência desse processo não nos invalida, apenas nos localiza como Ser no mundo.

Considerar que a Idade Média está em constante construção reforça que a sentença "isto é um manuscrito medieval" demarca uma amplitude considerável. Tal observação abrange também uma produtividade muito diferenciada, a depender não só do tempo, em sentido estrito, como da datação do manuscrito e do leitor, da região geográfica, de quem faz a encomenda, de quem a executa, da disponibilidade de materiais para feitura do manuscrito e do próprio tempo de onde partem as construções históricas.

Essa amplitude intensifica a necessidade de se pensar o manuscrito medieval, bem como outros objetos de estudo, não como um elemento estanque, hermético, mas suscetível ao seu contexto (em seu tempo) e ao nosso olhar (em nosso tempo). ${ }^{9}$ Refletir sobre essas necessidades propicia condições para que se estabeleçam relações entre a existência do manuscrito, sua materialidade e nossas ferramentas de trabalho. Quer dizer que o manuscrito não pode ser entendido de modo isolado. Não se pode esquecer de que o cristianismo é uma

que não se pode criar ("inventar") sem um depósito de memória ("inventário") a partir do qual e com o qual inventar, mas também que tal depósito de memória está efetivamente "inventariado", que seus materiais se encontram em "locais" prontamente recuperáveis. Algum tipo de estrutura locacional é de fato um pré-requisito para qualquer pensamento inventivo". CARRUTHERS, Mary. A técnica do pensamento: meditação, retórica e a construção de imagens (400-1200). Campinas, SP: Editora da Unicamp, 2011, p. 36-37. Na obra de Carruthers, fica clara a separação entre a memória e o inventário. A memória vale-se desse depósito organizado, mas ela não se limita a essa organização. Seu funcionamento implica relações mais complexas que o arquivar e desarquivar de dados. Sobre a ideia de memória, conferir também MENESES, Ulpiano T. Bezerra de. A história, cativa da memória? Para um mapeamento da memória no campo das ciências sociais. Revista do Instituto de Estudos Brasileiros, 34, 1992; NORA, Pierre (org). Les lieux de mémoire. Paris: Gallimard, 2008.

${ }^{9}$ Ao pensar as duas partes dessa relação, o que olha e o que é olhado, Didi-Huberman explora a dialética do ver em "O que vemos, o que nos olha" (1992). O autor vale-se, a princípio, dos pensamentos de Walter Benjamin para refletir sobre os conceitos de imagem dialética rumo a uma imagem crítica, principalmente sobre o aspecto fenomenológico dos conceitos. As discussões propostas engendram um pensar sobre a imagem, sua produção e recepção, bem como destaca o "entre", o espaço que coloca de um lado o observar e, de outro, a obra que retorna o olhar. DIDI-HUBERMAN, Georges. O que vemos, o que nos olha. Tradução Paulo Neves. São Paulo: Ed. 34, 1998. 
religião do Livro. As Escrituras narram a criação da humanidade, seu destino e carregam as palavras sagradas. O livro é tido como um objeto de valor, tanto material quanto simbólicoreligioso. Os livros também participam como elemento central em acontecimentos milagrosos e no quotidiano dos rituais religiosos. Instaurou-se no imaginário medieval uma relação mágica e ritual com o livro, também potencializada pela dificuldade de sua produção. ${ }^{10}$

A preocupação dos homens do medievo em conservar a herança cultural escrita levou à elaboração de manuscritos por vezes de grandes dimensões e de grande custo. Ao lado daqueles feitos para o uso diário, para estudo, para a liturgia, ou para outras funções laicas, havia aqueles feitos quase como monumentos, mais para serem apreciados que lidos. Estes, em geral, possuíam maior número de imagens que aqueles que chamaríamos de "mais próximos à prática", o que encarecia sua produção.

Esse é o caso do manuscrito conhecido como Beatus de Facundus, executado em 1047 pelo copista Facundus para os reis de Leão e Castela, Fernando I e Sancha. Conservado na Biblioteca Nacional da Espanha (Vitr. 14-2), ${ }^{11}$ o Beatus de Facundus possui em seus 316 fólios $(36 \times 28 \mathrm{~cm})$ um conjunto de 98 miniaturas, muitas das quais chegam a ocupar uma página inteira, e sete delas ocupam duas páginas. $\mathrm{O}$ variado número de imagens, marcadas por grande intensidade e variação cromática e pelo uso de materiais caros, como o ouro, intensifica o valor simbólico do objeto e o distancia de um uso diário, aquele em que se salienta a utilização do conteúdo textual. ${ }^{12}$

As imagens presentes no Beatus de Facundus, bem como, em geral, nos manuscritos medievais, não são ilustrações do texto, no sentido mais estrito do termo. Do latim ilustratio,

\footnotetext{
${ }^{10}$ A importância dos livros para o medievo pode também ser evidenciada pela ação de um milagre, quando eles também podiam ser alvos de um milagre. Em "Vita Sancti Fructuosi", Frutuoso de Braga opera um milagre para salvar um conjunto de livros das águas de um impetuoso rio. A carga de livros carregados pelo santo teria caído após se arrebentar a corrente que a prendia em um cavalo. Os livros foram recuperados de modo milagroso sem sofrerem dano algum. NOCK, Frances Clare (ed. trad.). Frutuoso de Braga. The Vita Sancti Fructuosi. Washington: The University of America Press, 1946, p. 109-110.

$11 \mathrm{O}$ manuscrito encontra-se inteiramente disponível em: <http://bdh-rd.bne.es/viewer.vm?id=0000051522>. Acesso em: 29 out. 2014.

12 A sentença "isto é um manuscrito medieval" transforma-se, em nosso estudo, para "isto é um manuscrito iluminado", uma alteração que modifica profundamente o objeto e as ferramentas que escolhemos para estudá-lo. O formato da sentença aqui proposta não é gratuito. Sua aproximação com a pintura "La trahison des images", de René Magritte (1926 e 1952), que carrega a frase "Ceci n'est pas une pipe", e principalmente com o texto escrito por Foucault, "Isto não é um cachimbo" (1967), é também já um indicativo de que, no decorrer desta dissertação, trabalharemos com as ideias de representação do visível e representação linguística, atentos para os lugares da imagem e do texto. FOUCAULT, Michel. Isto não é um cachimbo. Tradução Jorge Coli. Rio de Janeiro: Paz e terra, 1988. A designação é um exercício, ela cria delimitações e definições a serem questionadas assim que postas. Falar sobre representação a respeito de imagens medievais faz parte desse exercício, para compreendermos, adiante, que a imagem medieval não pensa a representação senão a partir do enunciado da própria Encarnação.
} 
a ilustração seria uma "ação de esclarecer", uma elucidação do texto em outra forma visual. Como uma tradução, a imagem seria externa ao manuscrito, ou seja, a sua retirada não traria prejuízos ao objeto, senão o de uma subtração formal.

Mas, a imagem é somente forma? O campo de estudos da "História das imagens" discute que as dimensões do estudo da imagem não se reduzem às questões estéticas, formais, mas pautam os sentidos e funções da imagem em sua vinculação com o objeto que lhe dá suporte (nesse caso, o livro manuscrito) e com o ambiente no qual e para o qual foi produzida. A imagem medieval, assim como muitas imagens do nosso tempo, não se subordinam ao texto, elas funcionam com ele. "Palavras e imagens juntas são dois 'modos' da mesma atividade mental - invenção". ${ }^{13}$ A imagem, e o manuscrito como um todo, deve ser compreendida em toda sua complexidade - em sua forma, estrutura, conteúdo, contexto, funcionamento e funções.

Discorrer sobre as imagens medievais através de suas várias perspectivas de existência (material, simbólica, mística e ritualística) reforça a necessidade de reafirmarmos a imagem como conceito distante do legado da História da Arte dita tradicional e formalista. A imagem em um manuscrito não é uma ilustração, tampouco um elemento didático para aqueles que não saberiam ler. ${ }^{14}$

Falamos de imagem para nos referirmos ao termo imago, adotado por autores como Jean-Claude Schmitt, Jean-Claude Bonne, Jérôme Baschet e Jean Wirth. ${ }^{15}$ A imago ultrapassa um caráter puro de representação e alcança três domínios de ação: o das imagens materiais (imagines), do imaginário, aquele das imagens mentais, oníricas e poéticas (imaginatio), e diz respeito ainda à antropologia e teologia cristãs como um todo. Neste último domínio, a imago

\footnotetext{
${ }^{13}$ CARRUTHERS, Mary. A técnica do pensamento: meditação, retórica e a construção de imagens (400-1200). Campinas, SP: Editora da Unicamp, 2011, p. 210.

${ }^{14}$ É comum, infelizmente ainda hoje, encontrarmos referências às imagens medievais como compondo uma "Bíblia dos iletrados". Essa expressão, apropriada de uma carta do papa Gregório Magno, escrita em um contexto preciso, em que havia um questionamento do uso de imagens pela Igreja, além de não dar conta de todo o pensamento de seu autor, tampouco consegue abarcar a grande complexidade e o alto grau de funcionalidade das imagens medievais. Ademais, se limitarmos a funcionalidade imagética no medievo às três funções básicas extraídas a partir do pensamento de Gregório Magno - ensinar, recordar e comover - em que categoria estaria a produção visual sem intencionalidade didática, desprovida de explícitos valores morais e de caráter narrativo? É uma generalização que não comporta a dimensão estética da produção medieval, e cria uma hierarquia que põe à margem, por exemplo, a ornamentação, tão importante para aquelas manifestações.

${ }^{15}$ Sobre as imagens medievais e a ideia de imago, conferir SCHMITT, Jean-Claude. La culture de l'imago. Annales. Histoire, Sciences sociales, 51 année, n.1, 1996, p. 3-36. Disponível em: <www.persee.fr/doc/ahess_0395-2649_1996_num_51_1_410832>. Acesso em: 23 nov. 2015.; BONNE, Jean Claude. À la recherche des images médiévales. Annales. Économies, Sociétés, Civilisations, $46^{\mathrm{e}}$ année, n. 2, p. 353-373, 1991. Disponível em: <www.persee.fr/doc/ahess_0395-2649_1991_num_46_2_278951>. Acesso em: 23 nov. 2015; BASCHET, Jérôme. L'iconographie médiévale. Paris: Gallimard, 2008; WIRTH, J. L'image médiévale: Naissance et développements (VIe-XVe siècle). Paris: Méridiens Klincksieck, 1989.
} 
encontra na história cristã seu fundamento, na "[...] concepção do homem criado ad imaginem Dei e prometido à salvação pela Encarnação do Cristo imago patris". ${ }^{16}$

O dogma da Encarnação, segundo Didi-Huberman, ${ }^{17}$ faz um trabalho de substituição do visível pelo visual, quer dizer, Deus, invisível e intangível, é presentificado no Cristo. Cristo não é uma imagem visível no sentido imitativo de Deus (como mimese, representação fiel de um objeto), mas é a presentificação do divino no mundo sensível. Deus torna-se presente e não aparente. A imago exerce função mediadora entre os homens e o divino, pertence mais à ordem visual e do indício que à ordem da representação. "A imagem medieval se impõe como uma aparição, entra no visível, torna-se sensível". ${ }^{18}$

As imagens cristãs, pela Encarnação, pertencem ao domínio do que Didi-Huberman chama de figurabilidade ou, simplesmente, figura. A noção de figura guarda um sentido latente de mistério teológico, constitui para os cristãos um

[...] recurso para aceder a um conhecimento que lhes continuava vedado [na intangibilidade de Deus e dos seres divinos]. E este recurso, afirmemo-lo de novo, tinha o nome de um desvio: um desvio forçado pela figura fora da coisa... para a reencontrar. [...] O historiador da arte chama muitas vezes 'figura' ao que um homem da Idade Média teria simplesmente chamado historia ou 'sentido literal', a saber o contrário da figura. [...] recusamos reconhecer nas imagens de arte esse trabalho de abertura, de equívoco e de virtualização a que os homens de uma longa Idade Média não tinham, no entanto, deixado de recorrer em nome de um mistério teológico - e que certas disciplinas das ciências humanas hoje reconhecem, reencontram e teorizam sob o ângulo de um conceito renovado da figurabilidade. ${ }^{19}$

A figura encontra na presença a ausência. Ela não representa o ausente de modo direto e fiel como cópia, mas presentifica o ausente através do desvio. Essa noção é fundamental para se compreender a presença da imago na Idade Média, em seus três domínios, bem como o modo através do qual as imagens do Beatus de Facundus são essenciais para que o manuscrito exerça as funções as quais é destinado. O texto bíblico, ele também, é uma imago, ou um conjunto de imagens que opera(m) pelo desvio. São Paulo, em sua primeira epístola a Coríntios, fala desse desvio como recurso temporário, que deixará de existir quando o terreno

\footnotetext{
${ }^{16}$ SCHMITT, Jean-Claude. O corpo das imagens: ensaios sobre a cultura visual na Idade Média. Bauru, SP: EDUSC, 2007, p. 45.

${ }^{17}$ DIDI-HUBERMAN, Georges. Poderes da figura: exegese e visualidade na Arte Cristã. Revista Comunicação e Linguagens, n. 20. Tradução de Virgínia Andrade e Leonor Caroça. Lisboa, p. 159-173, 1994.

${ }^{18}$ SCHMITT, Jean-Claude. O corpo das imagens: ensaios sobre a cultura visual na Idade Média. Bauru, SP: EDUSC, 2007, p. 16.

${ }^{19}$ DIDI DIDI-HUBERMAN, Georges. Poderes da figura: exegese e visualidade na Arte Cristã. Revista Comunicação e Linguagens, n. 20. Tradução de Virgínia Andrade e Leonor Caroça. Lisboa, p. 159-173, 1994, p. 167.
} 
e o divino se encontrarem no mesmo plano, no dia do Juízo Final: "Hoje vemos como por um espelho, em enigmas, mas então será face a face" (1 Coríntios 13, 12). A teologia Cristã fala por imagens em sentido amplo de imago através do desvio. A sombra de uma árvore não é uma árvore como tal, mas guarda semelhança com o modelo. Um homem justo não é uma árvore, mas é "[...] como árvore plantada às margens de um curso d'água, dá frutos na época certa e sua folhagem nunca seca" (Salmo 1,3). Na teologia cristã o desvio, ou a figura, torna a imago uma linguagem adequada à linguagem do Verbo. Aquela que caminha entre o divino e o terreno, que possui poderes ritualísticos e simbólicos para alcançar os homens na terra sem perder sua referência com o modelo intangível. Essa lógica não se reduz às imagens de Deus, mesmo quando encarnado em Cristo, mas é extensiva a toda a divindade, a todo o fruto que dela provém.

$\mathrm{Na}$ relação com o divino, nenhum aspecto da imago deve ser ignorado. Cada elemento compositivo da imagem é, por extensão, sagrado e essencial para o discurso a que se pretende. A redução do poder da imagem a um papel ilustrativo e, portanto, subordinado ao texto, ganhou força com a ideia de que esse discurso seria de uma ordem mais literal que simbólica. A imagem medieval como ilustração negligencia o caráter analógico do texto sagrado, da imagem material e da teologia cristã como um todo. A verdade cristã está fora da realidade, encontra-se em plano superior, acessado de modo indireto pelo pensamento analógico, construído na imago. Pela analogia buscam-se similitudes entre aquilo que é conectado "[...] em uma totalidade que os ultrapassa e é comum a cada elemento". ${ }^{20}$

Como seria possível estudarmos uma imagem sem considerar que cada traço é analogicamente divino e funcional para o discurso sagrado? $\mathrm{Na}$ destituição do próprio funcionamento da imagem, elementos como os ornamentais foram considerados um gênero menor. Reduzido ao aspecto decorativo, o ornamento seria externo às significações da imagem. Seu caráter supérfluo e externo à composição é uma concepção ainda hoje reforçada pelo legado de autores do final do século XIX e início do XX, ao exemplo de Adolf Loos e Louis Sullivan. Reproduzir tal discurso é ignorar o tempo de onde partem as construções históricas desses autores para utilizá-los como fórmulas antiornamentais sintetizadas em que o ornamento é uma decoração muitas vezes desnecessária. É preciso atentar-se para o objeto sobre o qual se debruçam - o ornamento relacionado à produção artística e utilitária moderna, ligada à produção industrial própria do século XIX e início do XX. A transposição sintética de

${ }^{20}$ FRANCO JR., Hilário. Modelo e imagem: o pensamento analógico medieval. Bucema. Bulletin du centre d'études médiévales d 'Auxerre, Hors-série n.2, 2008. Disponível em: 〈http://cem.revues.org/9152>. Acesso em: 06 jan. 2016. 
seus escritos para o estudo da ornamentação medieval resulta em análises simplistas, as quais excluem completamente a relação divina das imagens medievais.

A valorização do aspecto estético e decorativo do ornamento privilegia análises em termos estilísticos, que buscam datações ou o estabelecimento de procedências. Tais indícios são úteis para uma abordagem filológica, mas limitadores para uma análise em que a ornamentação, muito presente nas imagens medievais, participa da composição e do poder da imagem, que ultrapassam a função decorativa e os aspectos formais do ornamento.

Em contramão a essa tendência reducionista, herdeira dos debates modernistas, encontramos o trabalho do historiador da arte e medievalista francês Jean-Claude Bonne. Desde a década de 1980, Bonne pauta por análises que restituem ao ornamento seu caráter funcional. Linhas, entrelaços, motivos geométricos e vegetais, as cores e demais elementos compositivos, participam do ritmo e, em diferentes graus, da narrativa da imagem. Deixar de pensar o ornamento como um elemento acessório implica que qualquer exclusão pode ser prejudicial à imagem e à pesquisa que a ela se dedica.

Ao abraçarmos a imagem como um objeto que "faz figura", ${ }^{21}$ que opera em sua totalidade como imago, afastamos este trabalho de análises que privilegiam apenas um aspecto da imagem para considerarmos o ornamento como um dos elementos de acesso ao objeto que pretendemos estudar, o Beatus de Facundus. A funcionalidade do ornamento pode mostrar-se como um modo de orquestração da imagem, ${ }^{22}$ de composição honorífica que estrutura o discurso e espacializa o manuscrito. Dizemos espacializar no sentido de reger lugares, aqueles que não podem ser mensurados e não se apresentam de modo matematicamente homogêneo. O lugar da imagem e os lugares regidos pelo ornamento são aqueles próprios à experiência, à vivência da teologia cristã no sensível, em diálogo com o sagrado. Esses lugares são marcados graficamente na superfície de inscrição da imagem medieval pelo trabalho do ornamento.

Pesquisar a funcionalidade do ornamento não exclui, pelo contrário, fortifica a importância da materialidade do objeto para sua compreensão. É pela matéria visível do ornamento que ele alcança a visualidade, ou seja, um modo de ser recepcionado através não exclusivamente de seu corpo, mas pela sua ação no sensível de quem o olha.

\footnotetext{
${ }^{21}$ DIDI-HUBERMAN, Georges. Poderes da figura: exegese e visualidade na Arte Cristã. Revista Comunicação e Linguagens, n. 20. Tradução de Virgínia Andrade e Leonor Caroça. Lisboa, p. 159-173, 1994, p. 159.

${ }^{22}$ BONNE, Jean-Claude. De l'ornement à l'ornementalité: La mosaïque absidiale de San Clement de Rome. Actes du Colloque International: Le rôle de l'ornement dans la peinture murale du Moyen Âge. Saint-Lizier, 1-4 juin 1995. Poitiers: Université de Poitiers, 1997, p.103-119.
} 
No interesse de frisar, por um lado, a materialidade das imagens, e, por outro, seus usos e funções, notadamente de caráter litúrgico e devocional, aderentes ao objeto, Jérôme Baschet ${ }^{23}$ se refere às imagens medievais como imagens-objeto. $\mathrm{O}$ autor considera, ainda, que o status de tal objeto pode ser determinado a partir do valor econômico e simbólico dos materiais empregados e de suas propriedades estéticas. ${ }^{24}$

[...] propomos a noção de imagem-objeto a fim de sublinhar que a imagem é inseparável da materialidade de seu suporte, mas também de sua existência como objeto, agiu e age em lugares e situações específicas, implicada na dinâmica das relações sociais e das relações com o mundo sobrenatural. ${ }^{25}$

Em sua dimensão de objeto, o valor material do Beatus de Facundus se sobressai como códice de luxo, valor que implica não apenas em riqueza material (valor financeiro dispensado na encomenda), mas em sua importância simbólica. Como imagem-objeto, entendemos que essas imagens mantêm-se abertas às funcionalidades do suporte. Elas encontram seu lugar no rito, no gesto, na imaginatio (sonho, visão, imagem mental) e em outras muitas formas de uso e trabalho que uma imagem possa assumir. Embora tal afirmação possa ganhar tons de "definição total", este não é o caso. Não nos interessa cristalizar a imagem e torná-la inerte em uma só extensa definição-atuação. A imagem, e o objeto, vivem no tempo de um ritual, na oração do fiel. Eles se modificam com a passagem do tempo, não apenas materialmente, em seu desgaste, mas em sua função e poder. Como o manuscrito, também as imagens, e os ornamentos nelas presentes, trabalham dentro de um tempo específico, aquele do reinado de Fernando I. Falar de imagem-objeto é também restituir ao ornamento seu caráter temporal e seu lugar na sociedade de Leão do século XI.

Todos esses modos de compreensão da imagem, e outros que trataremos mais adiante, pautam por uma abertura dos conceitos a novas construções. Uma maior variedade de enfoques sobre as imagens permite que o objeto permaneça aberto, que outros modos de entendimento se desenvolvam sem que um anule o outro, mas que trabalhem dialogicamente para que a imagem exerça seus poderes na sociedade medieval.

É importante não fecharmos as brechas através das quais acessamos nosso objeto de estudo. Manter um objeto aberto em suas potencialidades implica um maior esforço para

\footnotetext{
${ }^{23}$ BASCHET, Jérôme. L'iconographie médiévale. Paris: Gallimard, 2008.

${ }^{24}$ Para maiores informações sobre as imagens medievais e a imago, ver o artigo BONNE, Jean Claude. À la recherche des images médiévales. Annales. Économies, Sociétés, Civilisations, 46 année, n. 2, p. 353-373, 1991. Disponível em: <www.persee.fr/doc/ahess_0395-2649_1991_num_46_2_278951>. Acesso em: 23 nov. 2015.

${ }^{25}$ BASCHET, Jérôme. L'iconographie médiévale. Paris: Gallimard, 2008, p. 33-34, tradução nossa.
} 
pensar as ferramentas de análise. Em vista das aberturas que os conceitos ora propostos apresentam, não nos basta pensar em uma única ferramenta. Não ignoramos as contribuições de determinados métodos para essa pesquisa, mas os delimitamos dentro de seus espaços próprios de atuação.

Pensemos em um ornamento de acanto. A iconografia não pode nos fornecer uma consideração estética do ornamento, mas serve como base para o entendimento da narrativa geral da imagem. Não poderíamos falar de um ornamento de acanto sem antes observar se há uma relação de tipo iconográfico com outros elementos da composição. A análise estilística e filológica também poder ser interessante quando esse suposto acanto aparenta guardar uma relação estilística com imagens da Antiguidade. Quando questionamos sobre a possibilidade desse acanto exercer um caráter simbólico, uma relação com o invisível de modo visível, pautamos pela iconologia. Mas esta ainda enrijece as aberturas simbólicas em significados que devem ser necessariamente encontrados, que permitem a existência do invisível como oposto do visível, mas que não atinge o campo visual, próprio da figura. Visível (por conta da matéria), legível (em sua busca por fontes textuais) e invisível (metafísico, que não corresponde a uma realidade sensível) são saberes da imagem, próprios de análises semiológicas, as quais buscam os significados, mas que, em geral, não abrem margem a uma

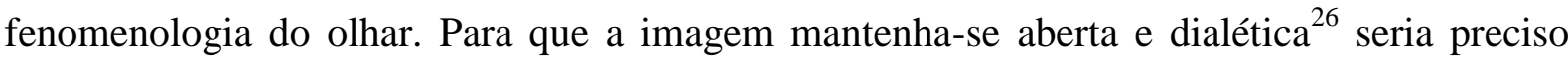
voltar-se também para o não-saber, aquele aspecto fenomenológico do sensível que não pode ser clarificado pelo próprio conhecimento (intelecto).

Nenhuma ferramenta, método propriamente dito, seria suficiente para abarcar um nãosaber senão pelo indício. Optamos, em respeito às aberturas dos conceitos que utilizamos, por lidar com a imagem de modo processual, isto é, no reconhecimento de que a pesquisa é um work in progress que "faz a vez" de um estudo finalizado. Não pretendemos criar classificações estagnadas, uma serialização que se perde de seu lugar de origem, nem lançar tipologias aplicáveis a qualquer objeto. O processo de pesquisa visa dar atenção às possibilidades de trabalho da ornamentação e da própria imagem em um manuscrito medieval ao mesmo tempo em que frisa o caráter construtivo do trabalho.

Nesse processo de análise das miniaturas, quando selecionamos quais instrumentos colocar dentro de nossa caixa de ferramentas, a noção de imagem-objeto é fundamental. É, em especial, o diálogo entre matéria, usos e funções que nos exige pensar as imagens de modo

\footnotetext{
${ }^{26}$ DIDI-HUBERMAN, Georges. Diante da imagem: questões colocadas aos fins de uma história da arte. São Paulo: Editora 34, 2013.
} 
serial e dialógico. As imagens do Beatus de Facundus não se apresentam de modo isolado. As 98 miniaturas formam um conjunto com o manuscrito. Elas se inscrevem no objeto e dialogam com os outros elementos do manuscrito, como o texto e o espaço das páginas. Como Jean-Claude Schmitt afirma, “[...] a obra verdadeiramente significante era a série em sua totalidade: o isolamento de uma imagem será sempre arbitrário e incorreto". ${ }^{27}$ A imagem não deve ser pensada isoladamente, porque ela se encontra em um lugar (ou lugares) que dialoga $(m)$ com suas funções e materialidade. Uma figura de Cristo em um retábulo não pode ser pensada de mesmo modo que uma figura de Cristo no Beatus de Facundus. O suporte, a localização espacial e temporal são essenciais para a análise. Considerar uma imagem de modo isolado de sua série, em um manuscrito, ou alheia a seu lugar social, pode gerar construções equivocadas.

Essa necessidade é claramente percebida no extremo de uma análise fragmentária de uma imagem de fólio duplo, em que não se encontra, por exemplo, uma explicação razoável para um personagem solitário no segundo fólio. Sobre esse personagem criam-se teorias e argumentações para sua solidão. Por que ele seria o único elemento figurativo que não está em conjunto, que não ocupa uma página inteira, mas encontra-se entre um fragmento e outro de texto? Nem precisamos dizer que tal suposta análise fragmentária não considerou a possibilidade de leitura do texto que o rodeia. Bastaria olhar ao lado, para o fólio anterior, para entender quem era o personagem, qual seu discurso, os motivos de sua localização espacial na página e o porquê de sua roupa ser toda vermelha e seus pés se apoiarem em uma repetição de ornamentos geométricos.

Dentro da série de miniaturas e de letras que ornam um manuscrito, os sentidos não podem se construir senão através da análise das constantes e das singularidades, dos ecos entre as imagens, dos processos de transformação que acompanham a leitura do livro. $^{28}$.

Para observarmos as constantes e as lacunas geridas pelo trabalho do ornamento, separamos as imagens em diferentes tipos de subséries. Algumas foram definidas a partir da relação iconográfica com o texto, outras quanto aos usos das cores, outras ainda pela organização espacial dentro da página que ocupa (Anexo A). É no exercício de classificações que melhor percebemos as utilidades e limites das tipologias. Trata-se de um processo

\footnotetext{
${ }^{27}$ SCHMITT, Jean-Claude. O corpo das imagens: ensaios sobre a cultura visual na Idade Média. Bauru, SP: EDUSC, 2007, p. 41.

${ }^{28}$ BASCHET, Jérôme. Inventivité et sérialité des images médiévales. Pour une approche iconographique élargie. Annales. Histoire, Sciences Sociales. 51e année, n. 1, p. 93-133, 1996, p. 112, tradução nossa..
} 
necessário, como ferramenta, ao lidarmos com análises seriais, mas não se define como a finalidade do estudo. Em outras palavras, pelo exercício contínuo de categorização é que nos tornamos mais íntimos de um grande grupo de imagens. Inventariar é criar intimidade com um mundo. A relação de proximidade permite que as imagens sejam apreendidas em nosso inventário, aquele que mantém diálogo com a memória e a inventio. Sua visualização dentro da série maior clarifica os argumentos a serem desenvolvidos e permite pensar e repensar características que podem ser utilizadas como diferenciadoras de um novo grupo. Dizemos exercício porque, apesar de utilizarmos um sistema de aspecto formal como base de aproximação entre grupos a serem estudados, sabemos que esse sistema é apenas um possível ponto de partida para o estudo do ornamento nas imagens do Beatus de Facundus. ${ }^{29}$

As ferramentas eleitas por um pesquisador muito têm a ver com o objeto que estuda, mas também com seu processo criativo de escrita (Anexo B), de invenção. Esquematizar e espacializar objetos e ideias pode ser um meio de encadeamento da escrita e processo de formação de uma rede de sentidos que se relaciona a todo o conjunto dissertativo. Somente num mundo inventariado a invenção, criação, é possível e desejável. Devemos observar as possibilidades análogas dentro e fora do objeto, do contrário, negaríamos o seu mundo, o nosso e o de suas misturas.

No medievo, o pensamento analógico é um recurso importante para se falar do intangível pelo desvio. "Alcançar o intangível pelo sensível torna-se possível pela observação de um tecido de reflexos, de comparações, de gradações, de metáforas, de símbolos. Em suma, de analogias". ${ }^{30}$ Esse recurso não é exclusivo da teologia cristã, mas existe, em diferentes graus, como modos de criar relações no discurso. ${ }^{31}$ Raciocinar por analogias, frisar

\footnotetext{
${ }^{29}$ Sobre a ferramenta que aqui chamamos de sistema, ver capítulo 4 e Anexo A.

${ }^{30}$ FRANCO JR., Hilário. Modelo e imagem: o pensamento analógico medieval. Bucema, Bulletin du centre d'études médiévales d'Auxerre. Hors-série $\mathrm{n}^{\circ}$ 2, 2008, p. 4. Disponível em: <http://cem.revues.org/9152>. Acesso em: 06 jan. 2016.

31 Umberto Eco afirmava, em 1977, que não se deve começar a pintar quando se escreve uma tese sobre Caravaggio, nem que um psiquiatra deve se expressar como um "doente mental" para falar de doenças mentais. [ECO, Umberto. Como se faz uma tese em ciências humanas. Lisboa: Editorial Presença, 2007, p. 165]. O processo de sensibilização do pesquisador pelo seu objeto de pesquisa não deve, nisso concordamos, levar a intimidade a um ato de reflexo ou elogio. No entanto, também não podemos negar que a rigidez da escrita acadêmica na área de história continua a ser atingida pelas discussões da relação entre ficção e história desde a fundação dos Annales, em 1920. A história opera por meio da escrita e é pela escrita que ela mostra seu potencial de construção. As polêmicas em torno do modo da escrita da história, na sua relação com a ficção e com a literatura, de modo indireto pelo uso da escrita, ainda permanecem vigentes. Alguns aspectos dessa polêmica pautam pelo esvaziamento crítico da discussão: "As reações ao diálogo histórico-literário correspondem, talvez, mais ao temor de que esta relação conduza à diluição dos saberes e à equivalência das narrativas. Numa linguagem mais grosseira, o medo de que se chegue a afirmar que 'história e literatura, é tudo a mesma coisa". [VIEIRA, Fernando G. P. A ficção como limite: reflexões sobre o diálogo entre história e literatura. Fronteiras: Revista Catarinense de História, Florianópolis, n.17, p.13-31, 2009, p. 29]. Ainda segundo Fernando G. P.
} 
relações, não nega o pensamento lógico, aquele que se estrutura de modo linear e encadeado, pelo contrário, muitas vezes o alimenta. ${ }^{32} \mathrm{O}$ pensamento analógico, seja ele explorado de modo verbal, pela escrita, ou de modo visual, pelos esquemas, contribui com a construção histórica das funcionalidades do ornamento nas imagens do Beatus de Facundus, pois prontifica-se a colocar o objeto de estudo em seu lugar, ou seja, de não negar-lhe seu tempo e seu corpo. O manuscrito, assim como os elementos que o constituem (texto e imagem, de modo mais estrito) são também objetos dessa relação.

No capítulo "As camadas da imagem ou Por que livros precisam de sobrenome" apresentamos o Beatus de Facundus, manuscrito com o qual construímos um diálogo para disparar a maior parte dos raciocínios encadeados ao logo do texto. A sentença "isto é um manuscrito medieval", com a qual abrimos nosso discurso, recebe outras designações mais aproximadas do estudo da materialidade do Beatus de Facundus. Pautamos por uma pequena introdução sobre a constituição material de um manuscrito que abre o entendimento para a posterior contextualização do manuscrito em questão. A análise codicológica do Beatus de Facundus evidencia o corpo do objeto e suscita as possibilidades do trabalho do ornamento na imagem, assunto central ao capítulo "Como abraçar uma máquina: o ornamento como engrenagem da máquina". Neste capítulo, traçamos relações entre a palavra de origem latina ornamentum e os conceitos de ornamental e ornamentalidade propostos por Jean-Claude Bonne diante da necessidade de se frisar o caráter funcional do ornamento. Através da análise de ornamentos de aspecto mais formal, como entrelaços e elementos figurativos, abordamos as funções decorativa, simbólica e de memória exercidas pelo ornamento.

No capítulo seguinte, "Uma sutil economia das cores", trabalhamos com a funcionalidade de um ornamento mais abstrato: a cor como ornamento. No estudo do uso do

Vieira, "Foi nas ciências naturais que a história dita positivista do século XIX buscou o modelo para seu paradigma de análise, vivo ainda hoje. Há quem diga que o historiador, ao lidar com o documento, trabalha de modo similar ao biólogo perante o DNA. Cabe perguntar: se, nos Oitocentos, o modelo que melhor se adequou à legitimidade da história foi o das ciências naturais, por que não, neste limiar de século XXI, a história buscar na arte, ou na literatura, novas fontes de inspiração? Ou, pelo menos, novos insights para sua produção?" [idem, p. 25]. Se as nossas ferramentas de análise das imagens pautam por relações dialógicas, não seria diferente na escrita das análises. Compartilhamos do questionamento de Fernando Vieira e acrescentamos que mesmo nas ciências duras, a escrita mostra-se, muitas vezes, mais aberta às relações com a escrita ficcional e com o sujeito em seu tempo que nas próprias ciências humanas. Lembremos-nos dos buracos de minhoca, as partículas de Deus e a Via Láctea. Metáforas e analogias, pelo visto, sempre estiveram presentes, tanto nos objetos de estudo quanto nos discursos de análise das ciências duras ou moles. Acreditamos que estamos distantes o suficiente da década de 1920 para afirmarmos a necessidade de se pensar na adequação da escrita às novas ferramentas de estudo.

${ }^{32}$ FRANCO JR., Hilário. Modelo e imagem: o pensamento analógico medieval. Bucema, Bulletin du centre d'études médiévales d'Auxerre. Hors-série $n^{\circ}$ 2, 2008, p. 4. Disponível em: <http://cem.revues.org/9152>. Acesso em: 06 jan. 2016. 
ouro e da cor púrpura, reforçamos a função simbólica exercida pelo ornamento e damos início à discussão sobre a função moduladora, aquela que hierarquiza a imagem, e o manuscrito, segundo ordens qualitativas. A orquestração da imagem de modo hierárquico mostra a cor e outros ornamentos como elementos que definem lugares, tema do capítulo "A orquestração do Fim do Mundo". A ordenação do espaço da superfície de inscrição evidencia o papel estrutural do ornamento. Por fim, apontamos que além dos motivos formais e das cores, também podemos observar o ornamento funcionar nas inscrições das imagens. $\mathrm{O}$ ornamento assume um papel de mediador entre texto e imagem e marca as inscrições como um lugar também próprio às funções ornamentais. As funções assumidas pelo ornamento nas imagens do Beatus de Facundus mostram que a imagem funciona através da engrenagem do ornamento. 


\section{AS CAMADAS DA IMAGEM OU POR QUE LIVROS PRECISAM DE SOBRENOME}

não cante lamúrias, meu bem,

a semente germinará

ou fará forte a terra. ${ }^{33}$

Há algumas décadas, bem sabem aqueles que, por sorte, têm longa vida, fazer levantamento bibliográfico era como preparar-se para ir ao campo de batalha. Antes de fazer as malas e ir ao encontro do precioso acervo, não poderia faltar em sua caixa de ferramentas um bom catálogo de títulos, um telefone e uma gentil bibliotecária que pudesse lhe confirmar a existência e disponibilidade do livro para consulta. $\mathrm{O}$ deslocamento era, muitas vezes, necessário, já que poucas bibliotecas no país poderiam ter algum título tão específico quanto o que se procura para o desenvolvimento satisfatório de uma pesquisa. Os mais bem relacionados e ricos de berço poderiam encomendar uma obra através de amigos europeus ou norte-americanos ou mesmo ir às compras no exterior. ${ }^{34}$ Caso contrário, não precisamos dizer do tamanho desapontamento quando o livro não correspondia à procura, ou mesmo quando a procura era interrompida pela notícia de que um único exemplar existia na Biblioteca Nacional, mas que ele "se perdeu".

Quando o encontro era bem sucedido, não se podia perder tempo. Sem a possibilidade de um empréstimo, era preciso por em prática a habilidade de ler/escrever, sem que uma tarefa se dissociasse da outra. Nem sempre o tempo durava tanto quanto se desejava. Era preciso a habilidade de um copista ou falsário e a pressa de um coelho. De volta para sua mesa, o pesquisador faria bom uso de todas as suas anotações e daquilo que não foi possível registrar, mas ainda estava fresco na memória.

Algumas dessas aflições não estão tão distantes daquelas que atormentaram esta pesquisa. Provavelmente a maior mudança esteja nas ferramentas. Não abandonamos o papel, nem a escrita, mas somamos outros recursos tecnológicos como o computador, o celular e

\footnotetext{
${ }^{33}$ Disponível em: <http://notamanuscrita.com/2016/01/09/beatusdefacundus/>. Acesso em: 23 nov. 2015.

${ }^{34}$ Se aqui o leitor estranha o uso de expressões como "rico de berço", bem como a naturalidade com que se diz que a bibliotecária é necessariamente do sexo feminino, compartilhamos do questionamento da suposta inocência das palavras e caminhamos para muitas mudanças que não devemos ter medo de evidenciar.
} 
uma câmera digital. Por vezes, abraçamos apenas um computador e sua conexão wi-fi ${ }^{35} \mathrm{O}$ deslocamento muda de plano e, sem sair de nossa mesa, podemos consultar acervos que antes eram inacessíveis. ${ }^{36}$ Está justamente nesse ponto a maior fonte de conflito entre gratificação e frustração. O êxito de encontrar parte do acervo só aumenta a decepção quando a outra parte lhe falta, ou quando ela está disponível, mas em uma qualidade inferior ao que era necessário para o objetivo final.

"É preciso fazer escolhas. Excluir conteúdo não pode ser uma amputação". Um conselho que aparenta ser simples, mas que mudou completamente o rumo desta pesquisa. Fazer cortes cirúrgicos sem prejudicar a funcionalidade geral do corpo, cortes necessários para que a atenção não se dispersasse e o acervo montado fosse completamente explorado.

Falar das amputações e de tempo perdido em estratégias mal sucedidas pode ser um ganho para aqueles que iniciam uma pesquisa e compartilham dos mesmos temores. Obviamente não vamos nos estender, aqui, sobre todas as vias sem saída que tomamos, faremos isso ao longo de todo o trabalho. Antes é preciso sublinhar a importância de se conhecer o objeto que se estuda.

Um agricultor não planta tomates da mesma forma que batatas, nem espera que a modificação de ferramentas e métodos faça nascerem batatas em tomateiros. Assim, antes de pensarmos na colheita, devemos dar a conhecer nosso objeto pesquisa. Partimos daquele que, aparentemente, é o ponto central deste estudo: um manuscrito medieval. Uma parte do cultivo já foi iniciada. Escolhemos a semente e o que esperamos que nasça. Mas como escolher as ferramentas necessárias para o cultivo se não nos familiarizamos com as questões que implicam o nascimento de um manuscrito?

\footnotetext{
${ }^{35}$ Tanto não abandonamos o papel que a maioria dos suportes atuais de escrita espelha-se na folha de papel, como a folha de A4 virtual na qual escrevo esta nota de rodapé. Se nos atentássemos mais para as associações de origem e semelhança, muito da visão apocalíptica de Fim do Livro seria deixada de lado.

${ }^{36}$ Tanto é assim, que muitos acervos de bibliotecas e museus estão em processo de digitalização e visualização online. Manuscrito, computador, celular, aplicativos... Impossível não ver importantes conexões entre essas ferramentas. Com vistas aos benefícios de diálogos tecnologicamente mais extensos, professores e alunos da Oficina de Didática Visual da Haute École des Arts du Rhin desenvolveram o aplicativo gratuito chamado "Du rouleau au codex". Através da interatividade e ludicidade, o aplicativo aborda a escrita e leitura no rolo e no códice. Além disso, a ferramenta traz ao público em geral obras antes inacessíveis dos acervos da Biblioteca Nacional e Universitária de Strasbourg (BNU) e da Biblioteca Medicea Laurenziana de Florença. Para maiores informações e baixar o aplicativo: <http://didactiquetangible.hear.fr/recherche-appliquee/app-du-rouleau-aucodex/>. Acesso em: 04 dez. 2015.
} 


\subsection{Entre frutos e sementes, um manuscrito medieval}

Se quisermos cultivar um tomateiro, é preciso determinar o tomate. Ele só será reconhecível quando suas partes exercerem suas devidas funções. Num sentindo muito próximo, um objeto só se torna um manuscrito medieval quando suas partes são determinadas pelo todo. Não basta ser escrito à mão, pois seria apenas um manuscrito. Ele precisa ser localizado em um lugar muito específico, em que toda sua materialidade se relacione e dialogue com o fruto final.

Vamos abrir o livro, assim como um botânico explora um fruto, para identificar cada elemento constituinte e compreender como cada parte desse todo é importante para sua existência. $^{37}$

Por associação, quando dizemos "manuscrito" é comum pensarmos em "folhas" e "pergaminho". Mas, nem sempre um manuscrito medieval foi confeccionado por folhas de pergaminho. Até o final da Antiguidade, o material mais utilizado como suporte de escrita era o papiro. Seu nome vem da planta da qual origina sua produção, a Cyperus papyrus, abundante nas margens do Nilo, no Egito. ${ }^{38} \mathrm{O}$ uso do papiro foi substituído progressivamente pelo pergaminho a partir do século II a. C., com destaque para a produção da cidade de Pérgamo (na atual Turquia). O pergaminho, feito da pele de animais, principalmente de cabras e ovelhas, tornou-se prevalente após o século IV. Essa substituição não pode ser entendida desconexa da prevalência do uso do códice em relação ao rolo, também a partir do século IV.

O rolo, ou volume, do latim volumen (derivado do verbo volvere, enrolar), era constituído por pequenos quadrantes de papiro, predominantemente, ou de pergaminho, coladas ou costuradas umas as outras para formar uma longa tira. (Figura 1). A cada uma das partes do papiro que são unidas dá-se o nome de folha, e no caso do pergaminho, de pele (ponto A na Figura 1). Essa longa tira era enrolada sobre si mesma, com o auxílio de duas hastes, de madeira ou marfim, em cada ponta ( $\mathrm{F} \mathrm{e} \mathrm{G).}$

\footnotetext{
${ }^{37}$ Não nos estenderemos tanto quanto gostaríamos sobre a constituição material e feitura de um manuscrito medieval por compreendermos as limitações práticas de um trabalho dissertativo. Apesar de breve, essa introdução ao manuscrito se insere em nossa preocupação com a carência de bibliografia sobre o assunto em português.

${ }^{38}$ Apesar de não nos aprofundarmos sobre o processo de feitura do papiro, sublinhamos a importância do texto "Historia naturalis", XIII, p. 71-82, de Plínio, sobre o assunto. Disponível em: <http://digilander.libero.it/Hard_Rain/Plinio.htm>. Acesso em: 13 nov. 2015.
} 


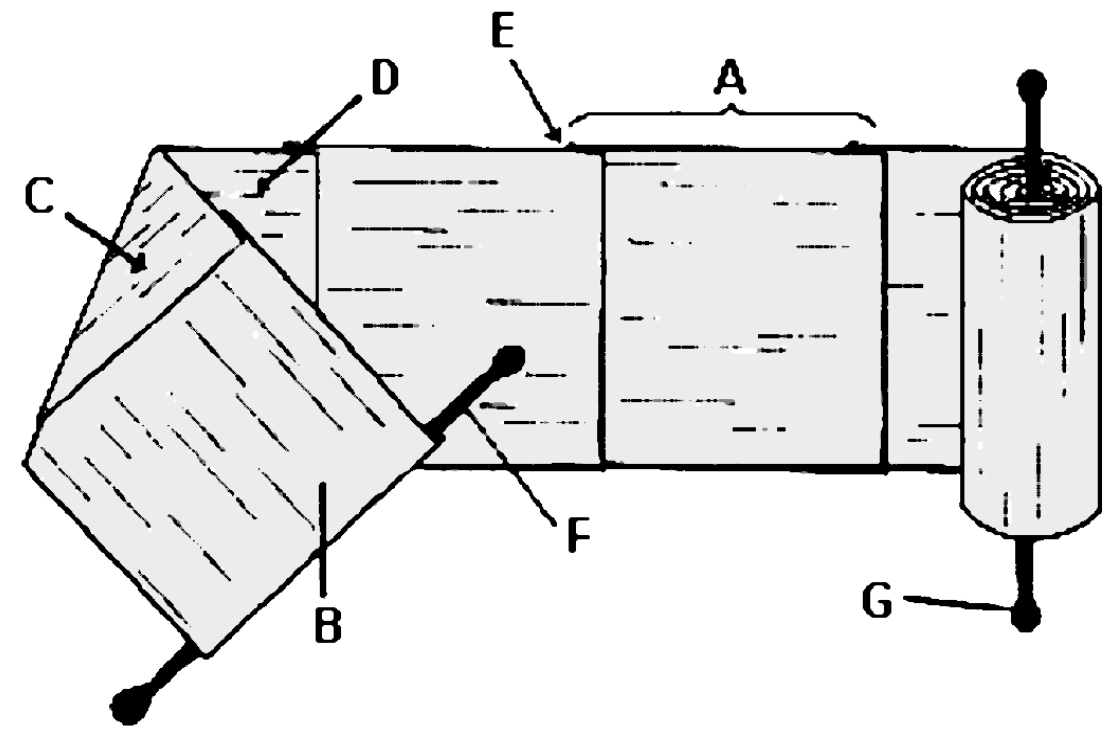

Figura 1. Volumen em papiro.

Folha ou Pele (A); Face invertida (B); Fibras perpendiculares ao sentido da escrita (C); Fibras paralelas ao sentido da escrita (D); Junção entre duas folhas (E); Hastes fixadas às folhas (F, G). Fonte: http://vocabulaire.irht.cnrs.fr/

Apesar da resistência das fibras do papiro, a estrutura membranosa das folhas só lhe permitia a escrita em um dos lados, em que a escrita se disporia de modo paralelo às fibras horizontais (D). Para que a parte externa do rolo apresentasse o título era preciso inverter a primeira folha contra o sentido das folhas restantes, de modo que as fibras horizontais permanecessem na parte externa (B). O texto escrito no papiro era dividido em colunas, páginas dispostas tanto de modo paralelo ao eixo de enrolamento (desenvolvimento horizontal), quanto perpendicular (desenvolvimento vertical). Para manter a dinâmica do objeto, era preciso desenrolar com uma das mãos e enrolar com a outra, encadeando páginas e leitura subsequente. ${ }^{39}$

A limitação de escrita no papiro em apenas uma de suas faces e a dificuldade de manuseio e transporte dos rolos foram os motivos mais diretos para que o conjunto pergaminho-códice se tornasse uma escolha mais econômica e vantajosa. Além de o pergaminho possibilitar maior espaço útil de escrita, o formato em códice $(\operatorname{codex})^{40}$, o livro,

\footnotetext{
${ }^{39}$ Para maiores detalhes, conferir XV CONGRÈS DE PAPYROLOGIE (Papyrologica Bruxellensia 16), 1978, vol. I, Actes... Bruxelas: Fondation Egyptologique Reine Elisabeth, 1978, sobretudo o artigo TURNER, Eric G. The Terms Recto and Verso. The Anatomy of the Papyrus Roll. Actes XVe congrès international de papyrologie, première partie, L'antiquité classique, Tome 49, 1980, Bruxelles: Fondation Egyptologique Reine Elisabeth, p. 471-472.

${ }^{40}$ A palavra codex, que dá origem ao termo códice, significa "bloco de madeira". A palavra já era usada para se referir a outro tipo de suporte de escrita, as tabuinhas de madeira enceradas. Essas tabuinhas geralmente eram unidas por cordões ou outras espécies de dobradiças e possuíam um funcionamento parecido com o do códice, mas seu preço e valor eram considerados inferiores em comparação ao códice de pergaminho. A cera permitia
} 
na sua forma atual, permitia uma leitura sem a obrigação de ser contínua. Com o códice, tornou-se possível circular livremente entre as seções, comparar passagens, enfim, folhear. Tente recortar todas as folhas do seu livro preferido e colá-las em formato de rolo para sentir o peso da obrigação de leitura contínua e a importância dessa mudança. Nem pense em sentar no banco da varanda em uma tarde de domingo com uma xícara de chá e seu livro de contos. Seria um desastre não poder optar pelo acaso do conto a ser lido e ter a certeza de que seria impossível ler apenas uma das faces sem perder partes da história.

Se no livro das tardes de domingo a numeração é por páginas, no manuscrito medieval é por folhas, chamadas de fólios, numeradas em frente e verso. Isto é, se a primeira página de um livro for 1 (p. 1) e a segunda 2 (p. 2), em comparativo teríamos fólio 1 frente, ou reto (f. 1) e fólio 1 verso (f. $1 \mathrm{v}){ }^{41}$

Para formar os fólios, o pergaminho pode ser dobrado ao meio ou cortado e montado posteriormente para originar o bifólio, a unidade básica do manuscrito e que compõe grande parte de nossos livros atuais (Figura 2). A peça de pergaminho também pode ser dobrada em quatro partes (in quarto) ou em oito (in octavo), a depender do formato desejado e do tamanho inicial do pergaminho. ${ }^{42}$

que as tabuinhas fossem reaproveitadas com facilidade e utilizadas para o aprendizado e usos ordinários. No evangelho de Lucas encontramos uma citação às tabuinhas quando perguntam a Zacarias que nome ele pretendia dar ao seu filho recém-nascido. Zacarias "pediu uma tabuinha para escrever e escreveu: "João é o nome dele"" (Lc 1, 63). Além do papiro, do pergaminho e da tabuinha destacamos o uso do papel desde o século II na China, e outros suportes como pedra, madeira, bronze, cerâmica, muros que também eram utilizados como suporte.

${ }^{41} \mathrm{O}$ pergaminho era feito da pele de animais por um processo que envolvia basicamente a limpeza do couro, a retirada dos pelos, o branqueamento em misturas químicas e a secagem em temperatura ambiente sob tensão. As fibras dilatavam e tornavam-se mais elásticas. Cada uma dessas etapas, desde a escolha do animal, é repleta de detalhes e fatores que alteram a forma do produto final, como a alimentação e idade do animal. FOURNIER, Sylvie. Brève histoire du parchemin et de l'enluminure. Paris: Éditions Fragile, 1995.

${ }^{42}$ Sobre as possíveis dobras do pergaminho bem como o significado de outras partes constitutivas de um manuscrito, conferir o vocabulário codicológico de Denis Muzerelle, disponível integralmente em versão hipertextual online desde 2002, com o patrocínio do Comitê Internacional de Paleografia Latina. MUZERELLE, Denis. Vocabulaire codicologique: répertoire méthodique des termes français relatifs aux manuscrits. Paris: Editions CEMI, 1985. Disponível em: <http://vocabulaire.irht.cnrs.fr/ >. Acesso em: 07 nov. 2015. 


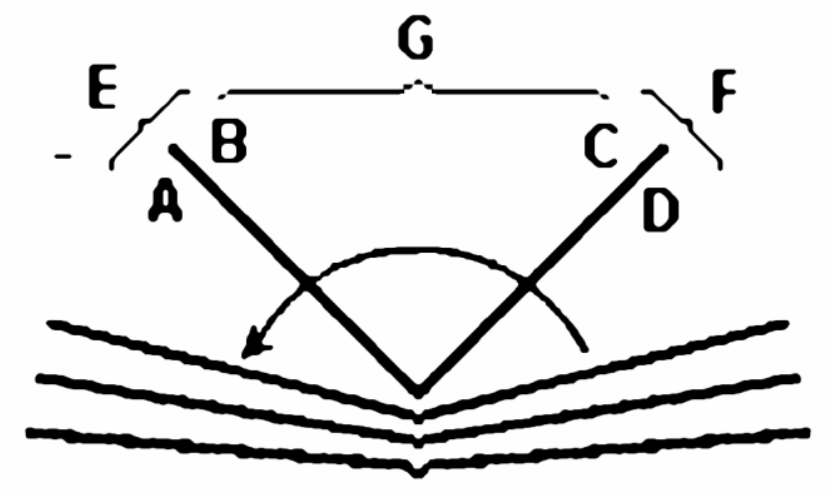

Figura 2. Bifólios.

Face anterior do fólio, a que aparece primeiro no sentido de leitura do texto (A, C); Face posterior do fólio (B, D); Cada uma das metades de um bifólio (E, F); Abertura ou Conjunto que consiste na parte de trás de uma folha e a frente da próxima $(\mathrm{G})$.

Fonte: http://vocabulaire.irht.cnrs.fr/

Depois que a pele é transformada em pergaminho e em seguida em fólios, é preciso prepará-la para receber a escrita, ou a imagem. Inicia-se o processo de picotagem em que uma série de furos (piques), feitos com variados tipos de instrumentos pontiagudos, organiza linhas mais ou menos visíveis. Quando traçadas, essas linhas resultam em uma espécie de folha pautada. O mais comum são piques próximos à margem, que seriam aparados na encadernação. ${ }^{43} \mathrm{O}$ pique que ordena as linhas pode ser produzido por contato direto entre o fólio e a ferramenta ou por contato indireto (Figura 3).

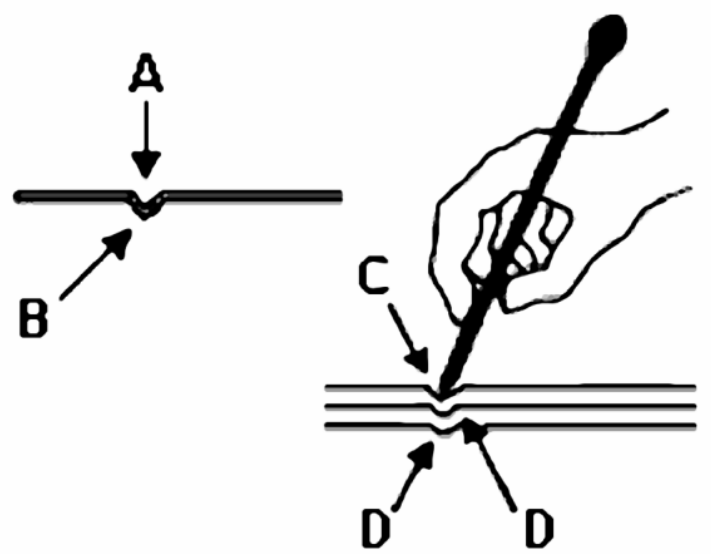

Figura 3. Processo de Picotagem

Pique por contato direto (A, C); Pique por impressão (B, D).

Fonte: http://vocabulaire.irht.cnrs.fr/

\footnotetext{
${ }^{43}$ RUIZ GARCÍA, Elisa. Manual de codicología. Salamanca: Fundación Germán Sánchez Ruipérez, Madrid: Pirámide, 1988, p. 133.
} 
Estas operações prévias têm a finalidade de auxiliar o escriba - e o copista - em sua produção. Além de traçar as linhas é preciso fazer a justificação que delimita o espaço destinado à escrita. ${ }^{44}$ Delimitado este espaço, começa o trabalho de escrita nos scriptoria (scriptorium, no singular), termo que significa "que serve para escrever", ${ }^{45}$ locais onde, em geral, até o século XIII, eram confeccionados os manuscritos no interior de mosteiros. Depois os copistas particulares se dedicaram cada vez mais a escrita para os laicos em outros locais como em oficinas régias (scriptoria regia). ${ }^{46}$

Em um scriptorium existia, normalmente, uma divisão de trabalho entre os monges. Alguns preparavam o manuscrito para a escrita, alisavam a pele para aperfeiçoar a superfície e faziam a picotagem, enquanto outros pautavam o pergaminho e copiavam o texto. O papel de escrita do texto era deixado aos escribas (scriba), ou copistas, quando se trata especificamente de uma cópia. Essa separação é, muitas vezes, sutil, visto que muitas obras eram compilações de passagens de outras obras, ou seja, não era uma cópia em sentido estrito. Havia também aqueles que iluminavam o manuscrito, o iluminador ou miniaturista. A diferença entre o uso de um termo ou outro também é tênue. O iluminador é aquele que "coloca luz" no manuscrito (illuminare), diz mais da técnica que o termo miniaturista, que tem na sua origem a própria matéria da imagem - miniare significa "pintar com minium" (vermelho). Todas essas funções, às vezes, podiam ser exercias por um único monge. ${ }^{47}$

Apesar de tentarmos especificar as funções para produção de um manuscrito, não é possível criar um modelo de produção dos scriptoria. Cada scriptorium possuía suas tradições individuais e sofria com a circulação de materiais entre as bibliotecas dos monastérios e da própria circulação de mão de obra. Muitos escribas e miniaturistas faziam um trabalho de "itinerância". De todo modo, algumas particularidades são úteis, por exemplo, na identificação de procedência e de datação dos manuscritos e para observar as circulações das obras em determinados espaços que serviam de base para os escribas ou como objetos a serem

\footnotetext{
${ }^{44}$ Maiores detalhes sobre a ordenação estrutural da página serão abordados no terceiro item deste capítulo, como parte da análise do Beatus de Facundus.

45 A palavra em latim medieval Scriptorium é composta pela raiz script-, scribere (escrever) somada a terminação -orium, do neutro singular para adjetivos que indicam espaço. Apesar de designar um espaço, o termo é utilizado como local para a produção da escrita e não necessariamente um espaço físico, um "ateliê" específico e necessariamente separado da cela de um monge. Disponível em: <http://vocabulaire.irht.cnrs.fr/pages/vocab2.htm>. Acesso em: 04 dez. 2015.

${ }^{46}$ DE HAMEL, Christopher. Scribes and Illuminators. Toronto: University of Toronto Press, 1992.

${ }^{47}$ SHAILOR, Barbara A. The Medieval Book. Toronto: University of Toronto Press, 1991, p. 68.
} 
copiados integralmente. Vale dizer que o ato de transcrição era também um ato de meditação, de oração e não simplesmente de realização de uma cópia "formal" do objeto. ${ }^{48}$

No processo de trabalho do escriba - e do copista - era feito mais que a escrita de palavras. Caso o manuscrito fosse iluminado, era papel do escriba e copista a delimitação do espaço da imagem. Além de deixar o espaço "em branco", poderia fazer indicações verbais das cores para partes da imagem. Esse entendimento sobre a construção da imagem e do texto deve muito aos manuscritos não finalizados, em que se podem observar partes do processo. ${ }^{49}$

Depois de finalizada a escrita e a iluminação, o manuscrito é encadernado. A organização dos fólios segue a união em estruturas chamadas de cadernos. Podemos observar essa formação em muitos dos nossos livros atuais. O nome "caderno" vem da estrutura mais comum em manuscritos medievais, o Quaternion (formado por 4 bifólios, 8 ff. ou 16 p.). Um mesmo manuscrito pode conter outros cadernos formados por apenas um bifólio independente (singulion), dois bifólios (Binion), três bifólios (Ternion), quatro (Quaternion), cinco (Quinion), seis (Septénion), oito bifólios (Octonion) ou ter uma estrutura de cadernos irregulares. Depois de formados, os cadernos são unidos para então formar o códice.

Seja por dobra sucessiva ou corte e montagem de bifólios, convém à ordenação dos cadernos que as faces dos pergaminhos coincidam (Regra de Gregory). ${ }^{50}$ Cada fólio, por originar-se da pele de animal, terá uma face de pelo e outra de carne. A coincidência entre as páginas colocadas frente a frente serve para preservar colorações e qualidades semelhantes quando o códice encontra-se aberto, visto que a absorção da tinta dá-se de modo diferente entre as faces. Se observarmos a figura 2 e supusermos que o bifólio é construído por dobra, a Regra de Gregory é inevitável: as faces de letra B e C seriam de mesma face (face carne com face carne ou face pelo com face pelo). A observação atenta a esta regra pode indicar a ausência de fólios quando as faces não coincidem. No caso de bifólio feito por montagem, as faces poderiam coincidir, mas não seria uma certeza.

\footnotetext{
${ }^{48}$ Sobre os processos de meditação e exercícios de memória relacionados ao ambiente monástico medieval; conferir CARRUTHERS, Mary. A técnica do pensamento: meditação, retórica e a construção de imagens (4001200). Campinas, SP: Editora da Unicamp, 2011.

${ }^{49}$ Só é possível dizer que a imagem não foi finalizada em comparação com todo o manuscrito e na observação do funcionamento da imagem. A presença de traços sem preenchimento de cor ou da aplicação de cor somente em algumas partes da imagem não significa necessariamente que o trabalho do miniaturista ficou incompleto. Pode ser um recurso da própria narrativa da imagem, confundida com o inacabado quando essa imagem não é vista em série.

${ }^{50}$ A Regra de Gregory ou Lei de Gregory é assim nomeada em referência ao erudito alemão Caspar René Gregory, o primeiro a fazer as observações técnicas que constituem o princípio, em finais do século XIX. GÉHIN, Paul (org.). Lire le manuscrit médiéval: observer et décrire. Paris: Armand Colin, 2005, p. 66-70.
} 
Montados os cadernos, eles seriam costurados e unidos a uma capa no processo de encadernação. A capa, assim como um ou dois fólios deixados em branco no início do manuscrito, é importante para a proteção do livro, como nossa capa atual. Também serviam como um indício sobre o valor econômico investido no objeto, a importância dele no seio de sua cultura de origem, e em contextos posteriores, no caso de substituição da capa, de subtração ou aderência de novos materiais. A materialidade do manuscrito é um corpo de denúncia. Cada subtração ou acréscimo, cada alteração pode declarar, àqueles que se prestam a ouvir, um pouco sobre o caminho percorrido pelo manuscrito até tornar-se um objeto de estudo. Em nossa prateleira podemos observar a ação do tempo sobre nossos livros. Sofremos com as páginas que amarelam ou enrugam no excesso de umidade de uma maresia insistente. Imaginem quantas ações um livro com séculos de idade pode denunciar. Em seu corpo encontramos marcas de eventos naturais, no desgaste da matéria que sofre com o envelhecimento, e agressões à sua ordem inicial. Uma imagem que pode ter fascinado uma geração, uma sociedade em específico, pode sofrer uma subtração local para tornar-se um presente, um objeto comercializável ou receber outro tipo de função que não a de compor o manuscrito original. Essas convivência e evidência de diferentes estratos de tempo em um mesmo objeto podem ser percebidas com maior claridade na arquitetura de igrejas medievais. Pensemos em quantos estilos diferentes existem em uma igreja considerada românica pela História da Arte. Sua fachada pode conter alterações próprias do estilo gótico e seu interior ser ornamentado por objetos do século XIX, e ainda encontrarmos imagens e ritos próprios do século XXI. Os manuscritos medievais também estão sujeitos ao tempo e a interferência humana. Cada fragmento de seu corpo pode apontar parte da sua história. Observá-lo em sua profundidade como imagem-objeto é respeitar suas especificidades e dar o primeiro passo para um entendimento basilar de que os materiais e a sua história (narrativa e espiritual) seguem o corpo e os ritos envolvidos nesse diálogo da matéria e do poder da imagem medieval. 


\subsection{Sobre a germinação: como determinar uma família de manuscritos}

As características elementares do manuscrito foram preenchidas. Observamos, de modo sucinto, a origem de um códice no desenvolvimento dos fólios, do espaço da escrita e imagem, dos cadernos e da encadernação. Dissemos também que a confecção se dava dentro de um scriptorium. Contudo, se pudéssemos encontrar manuscritos feitos segundo as descrições anteriores, mesmo que por um monge, ele ainda não seria medieval. Ainda é preciso identificá-lo, dar-lhe um nome e uma localização temporal. ${ }^{51}$ o que faz um manuscrito ser um Beatus?

O termo Beatus define uma série de manuscritos datados entre o século IX e XVI, que reproduzem o Comentário ao Apocalipse - In Apocalypsin B. Joannis Apostoli Comentaria-, compilado no final do século VIII. A compilação do protótipo, hoje perdido, é atribuída a um monge asturiano anônimo, conhecido pela alcunha de Beato de Liébana, que dá origem à denominação dos manuscritos. ${ }^{52}$ A atribuição tornou-se uma convenção entre os historiadores e historiadores da arte, visto que em nenhuma das cópias aparece o nome de Beato de Liébana ou de qualquer outra autoria para a compilação. E somente em alguns poucos aparece o nome dos copistas, iluminadores e/ou comitentes.

Parte dessa convenção teve início com a relação estabelecida entre o Beato de Liébana e o Comentário de Ambrosio de Morales, do século XVI. Por ordem de Felipe II, Morales realizou uma expedição em 1572, por regiões de Hispânia, para reconhecer as relíquias e códices das igrejas. Em seu trabalho, encontrou o Beatus de Facundus na biblioteca de Santo Isidoro, em Leão. A atribuição da obra a Beato de Liébana por Morales foi baseada na análise

\footnotetext{
51 Alguns objetos localizados em acervos museológicos que não possuem títulos são comumente catalogados como "Sem título". A obra "Sem título" recebe uma identificação no acréscimo de detalhes sobre sua materialidade por aqueles que convivem com o objeto. "Por favor, pegue o quadro 'Sem título de quadrados vermelhos", ou de sua autoria e materialidade: "Onde está a "publicação amarela do Kisko com 100 canetas?".

52 Em geral, ocorre certo conflito entre a nomeação das cópias e o nome do compilador, muito a depender da língua de origem do trabalho. É comum reunir a obra e o compilador sob o mesmo nome de "Beato", e desse modo, referir-se ao protótipo, o manuscrito do século VIII, como "Beato de Liébana". A fim de intensificar a diferença entre as cópias e o compilador, optamos por chamar o compilador sempre de "Beato de Liébana" (sem abreviações ou reduções). Já o termo em latim, Beatus, faz alusão a uma cópia em particular, seguida de sua identificação: Beatus de Facundus, ou Beatus de Fernando I e Sancha (em itálico, por ser uma palavra estrangeira). Para falarmos de mais de uma cópia, mantemos a mesma palavra em latim, mas em sua variação no plural: Beati.
} 
da dedicatória inclusa no Beatus de Facundus, direcionada a Etério, bispo de Osma, que seria, segundo Morales, amigo próximo de Beato de Liébana. ${ }^{53}$

A atribuição conjeturada por Morales foi reafirmada por Enrique Flórez, em 1770, a partir da correlação entre a dedicatória a Etério, presente no Beatus de Facundus, e dedicatória semelhante, também a Etério, na única obra de segura autoria de Beato de Liébana, conhecida como Apologético. Trata-se de uma carta de Beato de Liébana, endereçada ao arcebispo de Toledo, Elipando, divida em dois livros. O historiador da arte americano John Williams também corroborou para esta atribuição ao estabelecer paralelismos estilísticos do texto dessas duas obras. ${ }^{54}$ Contudo, vale ressaltar, como observou Manuel Díaz y Díaz, ${ }^{55}$ apesar da utilização, lato sensu, da palavra Beatos (ou Beatus e Beati, como aqui utilizamos no singular e plural, respectivamente) para referir-se a este grupo de manuscritos, deve-se, ao definir a autoria, sublinhar que a obra é "atribuível a Beato de Liébana".

Sendo um Comentário ao Apocalipse, os Beati possuem essencialmente o livro do Apocalipse, entremeado de comentários de Santos Padres para a interpretação da Sagrada Escritura. Na compilação, Beato de Liébana faz citações da exegese bíblica de autores como Santo Isidoro de Sevilha, São Jerônimo, Ambrósio, Santo Agostinho, Gregório de Elvira e Gregório Magno, bem como utiliza outros Comentários ao Apocalipse, principalmente os de Ticônio, Apríngio e Victorino. Apenas algumas palavras são de Beato de Liébana, o restante consiste em justaposição de textos bíblicos e de autores que emprega como fonte. ${ }^{56}$ Seu trabalho consiste, sobretudo, em criar relações entre as passagens e entre os comentários, intercalar textos e variar cláusulas. Portanto, mais que um autor de um Comentário ao Apocalipse, Beato de Liébana é um compilador, que coleta e une passagens de outras obras e autores no sentido de compor uma summa exegética do livro do Apocalipse. ${ }^{57}$

\footnotetext{
53 SÁNCHEZ MARIANA, Manuel. La tradición de los Beatos y el Beato de Fernando I y Sancha. In: WILLIAMS, John et al. Beato de Fernando I y Sancha. Barcelona: M. Moleiro, 2006, p.31-58, p. 34.

54 WILliAMS, John. The illustrated Beatus: a corpus of the illustrations of the Commentary on the Apocalypse. London: Harvey Miller, 1994, v.1.

${ }^{55}$ DÍAZ Y DÍAZ, Manuel Cecilio. La tradición del texto de los Comentarios al Apocalipsis. Atas do Simpósio para o estudo dos códices do Comentário ao Apocalipse de Beato de Liébana. Madrid, 1978, p.163-184.

${ }^{56}$ Sánchez Mariana afirma que o modo com que Beato compila os textos de outros autores nas explanatios, como um mosaico, ou colcha de retalhos, distancia-o consideravelmente das catenae, por não seguir uma ordenação sucessiva de textos de autoridades para a interpretação de um dogma. Ver SÁNCHEZ MARIANA, Manuel. La tradición de los Beatos y el Beato de Fernando I y Sancha. In: WILLIAMS, John et al. Beato de Fernando I y Sancha. Barcelona: M. Moleiro, 2006, p. 36.

${ }^{57}$ Em seu Comentário ao Apocalipse, Beato reúne em uma só obra um compêndio com passagens significativas de outros autores sobre o livro. O compêndio é de grande valor para se ter acesso a textos perdidos de outros exegetas cristãos anteriores. O Beatus é uma importante fonte de reconstrução do texto de Ticônio, pois Beato
} 
Como compilador, Beato de Liébana desenvolve uma compreensão enciclopédica que tem, provavelmente, seu maior expoente nas Etimologias de Isidoro de Sevilha, das quais ele também faz uso. ${ }^{58} \mathrm{O}$ estudo dos comentários utilizados por Beato de Liébana é feito a partir da análise das cópias posteriores, visto que o protótipo encontra-se perdido. As cópias guardam importantes diferenças entre si, com variações literárias e pictóricas. Dentre as principais está o acréscimo de um Comentário de São Jerônimo ao livro de Daniel, presente, sobretudo, no Beatus de Facundus, objeto desse estudo, e em alguns outros Beati.

De acordo com um levantamento de 1985, pode-se comprovar a existência de 34 cópias. Destas, 25 são códices e nove são fólios soltos (fragmentos). Dos códices, 23 contém iluminuras e entre os fragmentos, três são iluminados (Anexo C). Essa estatística foi realizada durante a Europalia, um grande festival internacional de arte que apresenta, a cada dois anos, um conjunto importante do patrimônio cultural, em colaboração com a Biblioteca Real Albert I. ${ }^{59}$ Esse empreendimento deu origem a exposição "Los Beatos", cujo catálogo contou com a participação de cinco grandes referências no estudo dos Beati: Luís Vásquez de Parga, Manuel Díaz y Díaz (na qualidade de filólogo latino), John Williams (no estudo da imagética dos Beati), Anscari Mundó (dedicado às questões paleográficas) ${ }^{60}$ e Manuel Sánchez Mariana, diretor da Seção de Manuscritos da Universidade de Madri.

Apesar de este levantamento ser referencial, não é possível afirmar com exatidão a quantidade de cópias existentes. Sempre podemos ser surpreendidos por um encontro não previsto. Em outubro de 2007 a lista de Beati cresceu. Através de um acordo de depósito de livros antigos pelos padres do Instituto Florimont à Biblioteca de Genebra, o Beatus de

não fez uso apenas do conteúdo exegético, mas também, provavelmente, da própria estrutura do Comentário de Ticônio, também dividido em 12 livros. "Na realidade, todos os comentaristas do Apocalipse dependerão, em maior ou menor grau, do comentário africano. Daí que grande parte dos estudiosos de Ticônio se esforçou por recuperar o então perdido Comentário ao Apocalipse". ROMERO POSE, Eugenio. Ticonio en la historia y literatura cristiana en el Norte de África. In: MARIN, M.; MORESCHINI, C. (ed.), Africa cristiana. Storia, riligione, letteratura. Brescia: Morcelliana, 2002, p. 159, tradução nossa. Sobre o empreendimento de "reconstrução" do texto de Ticônio, a partir de Beato, ver, sobretudo, o trabalho de Traugott Hahn, "Tyconius Studien", comentado por Romero-Pose em ROMERO POSE, Eugenio. Ticonio y su comentario al Apocalipsis. Salmanticensis, vol 32, fasc.1, pp.35-48, 1985. Disponível em: <http://summa.upsa.es/pdf.vm?id=0000007252\&page=1\&search=\&lang=es〉. Acesso em: 22 out 2014..

${ }^{58}$ Para Fontaine as Etimologias de Isidoro conservavam um reflexo do projeto Aristotélico de fazer um inventário do mundo. FONTAINE, Jacques. Isidoro de Sevilla. Génesis y originalidad de la cultura hispánica en tiempos de los visigodos. Madrid: Ediciones Encuentro, 2002, p.115.

${ }^{59}$ Disponível em: <http://www.europalia.eu/>. Acesso em: 13 ago. 2014.

${ }^{60}$ MUNDÓ, Anscari; SÁNCHEZ MARIANA, Manuel. El comentario de Beato al Apocalipsis: catálogo de los códices. Madri: Biblioteca Nacional, 1976. 
Genebra, como tem sido chamado, tornou-se o $27^{\circ}$ Beatus iluminado. ${ }^{61} \mathrm{O}$ desconhecimento da cópia pode ter sido favorecido pelo fato de esse Beatus estar incompleto e ser apenas a segunda parte de um códice. ${ }^{62}$

Devido à extensão temporal que alcançam as cópias do Comentário ao Apocalipse de Beato de Liébana, desde o século IX ao XVI, é compreensível a presença de certa variação na estrutura textual e no discurso imagético. Como elementos essenciais de identificação de um manuscrito como um Beatus, encontramos o prefácio, os dois prólogos e o Comentário ao Apocalipse, que a princípio podem ser atribuídos, em sua compilação, ao Beato de Liébana.

O prefácio (praefatio) é um texto breve e tecido em citações isidorianas, originadas, sobretudo, do tratado "Contra os judeus". Além da dedicatória da obra a Etério, Beato de Liébana cita as referências de sua obra:

Ditas coisas, que se encontram expostas não por mim, e sim pelos Santos Padres, tem sido reconhecidas neste livro, e apoiado por seus autores: Jerônimo, Agostinho, Ambrósio, Fulgêncio, Gregório, Ticônio, Ireneo (Victorino), Apringio e Isidoro, de tal maneira que o que não tenhas compreendido lendo em outros, neste o reconheça [...] Considera, pois, este livro como a chave de toda a biblioteca. ${ }^{63}$

Em seguida, o primeiro prólogo compila um texto de São Jerônimo sobre a vida de São João e o segundo é uma introdução ao Comentário ao Apocalipse. Os dois prólogos também fazem citações das fontes a serem utilizadas nos comentários. ${ }^{64}$

\footnotetext{
${ }^{61}$ O Beatus de Genebra (BGE, Ms. lat. 357) procede provavelmente do sul da Itália, datado entre o segundo terço e o final do século XI, e é composto por 97 fólios (ff. 149-245v). Apesar de ser o mais recente, o manuscrito está disponível online desde $2009 \mathrm{em}$ : 〈http://www.e-codices.unifr.ch/en/list/one/bge/lat0357〉. Acesso em: 02 dez. 2015

${ }^{62}$ Na primeira parte temos a obra "As instituições gramaticais", de Prisciano, datada entre o final do século XI e início do XII e que ocupa os fólios 1 ao 148v. Nos fólios 148 e $148 \mathrm{v}$ encontram-se inscrições sobre a propriedade do manuscrito em 1792-93 pela abadia de Aulphs (França). Uma análise da costura dos cadernos confirma que as duas obras foram unidas antes do século XVII, o que implica que o manuscrito encontrado em Aulphs possuía a formação atual, com as duas obras. Disponível em: <http://www.ecodices.unifr.ch/en/list/one/bge/lat0357>. Acesso em: 02 dez. 2015

${ }^{63}$ CAMPO HERNÁNDEZ, Alberto del; FREEMAN, Leslie G.; GONZÁLEZ ECHEGARAY, Joaquín (ed.). Beato de Liébana. Obras completas y complementarias. Edição bilíngue do latim ao castelhano. Madrid: Biblioteca de Autores Cristianos, 2004, v. 1, p. 33, tradução nossa.

${ }^{64}$ Além dos dois prólogos iniciais, existe um extenso prólogo que faz parte do Livro II do Comentário ao Apocalipse, com o seguinte título: "Sobre a Igreja e a Sinagoga. Para que você, leitor, conheça da maneira mais completa suas características próprias, e quem forma parte de cada uma". CAMPO HERNÁNDEZ, Alberto del; FREEMAN, Leslie G.; GONZÁLEZ ECHEGARAY, Joaquín (ed.). Beato de Liébana. Obras completas y complementarias. Edição bilíngue do latim ao castelhano. Madrid: Biblioteca de Autores Cristianos, 2004, v. 1, p. $122-123$.
} 
O texto do Comentário ao Apocalipse, estritamente, é dividido em doze livros, que se estruturam basicamente por uma sequência de fragmentos do Livro do Apocalipse, chamados de storiae, seguidos, a cada fragmento, por duas explanações: uma imagética e outra textual. Nas explanações textuais, chamadas de explanatio ("explicação do texto anterior"), ${ }^{65}$ Beato de Liébana repete cada uma das frases do texto anterior e explica o significado pela intercalação de comentários de vários pensadores de diferentes épocas, os quais reconheciam no texto do Apocalipse um material importante a ser estudado. Às vezes, esse significado pode se multiplicar em outros sentidos, a depender da extensão do grau de digressão e das analogias criadas. Muitos destes autores já tinham sido citados na obra desde o Prefácio. Essas explicações mostram-se amplas nos três primeiros livros e mais breves nos seguintes. ${ }^{66}$ Geralmente, cada storia é marcada no início pela expressão "incipit", que quer dizer "aqui começa", e finalizada com uma frase que começa com "explicit", ${ }^{67}$ quer dizer, "Aqui termina". O mesmo acontece com a explanatio.

Somamos ainda a interpretatio (Interpretatio Libri huius, Interpretação deste livro), que é uma explicação do texto do Apocalipse de modo resumido, a partir de trechos considerados mais significativos por Beato de Liébana e que vem logo depois do segundo prólogo, antes do Comentário ao Apocalipse. O desenvolvimento da interpretatio é muito similar ao da explanatio, pois o monge cita um fragmento do Apocalipse e em seguida o interpreta de acordo com suas fontes (Santos Padres) e segundo referências cruzadas que cria com outros textos bíblicos. Por exemplo, Beato de Liébana explica o Apocalipse 11, versículo 9 da seguinte maneira:

E gente de todos os povos, tribos, línguas e nações contemplarão seus cadáveres durante três dias e meio, quer dizer, trezentos e cinquenta, o que resulta três anos e seis meses. Devem entender isto espiritualmente: desde a paixão do Senhor até o tempo do Anticristo contam-se três anos e seis meses. Por um ano, cem anos, e por três, trezentos, e por cinquenta anos, seis meses: mistura, pois, o tempo presente e o

\footnotetext{
65 Para facilitar a comunicação, no correr do trabalho optamos pelo uso das palavras "explanatio" ou "comentário(s)" para nos referir as explicações do Apocalipse compiladas por Beato de Liébana, em distinção da expressão "Comentário ao Apocalipse", escrita em inicial maiúscula para referir-se ao nome da obra ou, a depender do contexto de emprego, a parte substancial de um Beatus, todo o conteúdo dos 12 livros.

${ }^{66}$ Para as storiae, Alberto Del Campo H. descarta a possibilidade do texto ser da Vulgata, uma versão latina da Bíblia traduzida do hebraico por São Jerônimo : "[...] pois contem variações, supressões e acréscimos". Sustenta, ao contrário, que se trata do texto do Apocalipse utilizado por Ticônio em seu Comentário, o mesmo utilizado pela Igreja africana no século VIII. Já na explanatio, encontra-se, às vezes, a versão utilizada pelo autores que emprega como fonte. CAMPO HERNÁNDEZ, Alberto del; FREEMAN, Leslie G.; GONZÁLEZ ECHEGARAY, Joaquín (ed.). Beato de Liébana. Obras completas y complementarias. Edição bilíngue do latim ao castelhano. Madrid: Biblioteca de Autores Cristianos, 2004, v. 1, p. 15.

${ }^{67}$ A palavra explicit vem do verbo explicare, desenrolar, expressão herdada dos rolos, porque, de fato, ao chegar ao final, havia terminado de desenrolar o rolo.
} 
futuro, como disse o Senhor no Evangelho: Virá, disse, a hora em que todos os que vos matar pensará que está prestando um serviço a Deus (Jo 16, 2). Nunca separa o tempo presente do último, naquele que se manifestará o Anticristo, porque o que acontece em seguida de forma visível, está acontecendo agora na Igreja de forma invisível. $^{68}$

A explanatio dessa passagem do Apocalipse, no Livro V, é muito similar, mas uma troca de palavras é significativa na mistura do tempo que é presente e futuro:

E gente de todos os povos, tribos, línguas e nações contemplam seus cadáveres durante três dias e meio Quer dizer, três anos e seis meses, que são trezentos e cinquenta anos, como dissemos acima, desde a paixão do Senhor até o Anticristo. Isto, como dissemos, acontece espiritualmente à Igreja. Mistura o tempo, já presente, já futuro. Contemplam, disse, e não contemplarão. Como o Senhor disse no Evangelho $[\ldots]^{69}$

$\mathrm{Na}$ interpretatio, Beato de Liébana escreve o início do trecho do Apocalipse como "Et videbunt ex populis [...]" (contemplarão), na explanatio o trecho começa com "Et vident ex populis [...]" (contemplam). A troca é evidenciada na própria explanatio, "Vident enim dixit, quia nin videbunt", em que o leitor é levado a se confrontar com dois tempos distintos que são um só nas palavras sagradas do Apocalipse. Ainda cria um jogo de uma autorrecapitulação do próprio texto do Comentário ao Apocalipse. Ao dizer "quos supra diximus" (como dissemos acima) e "ut diximus" (como dissemos), refere-se ao mesmo trecho citado na interpretatio.

As recapitulações utilizadas por Beato de Liébana não se limitam ao texto. Para John Williams, o texto é retomado em imagem, ou seja, em outra linguagem. ${ }^{70}$ As imagens não se reduzem a uma representação das passagens bíblicas, não são ilustrações do texto, no sentido mais estrito e literal. Sua localização entre a história (passagens do Apocalipse, storiae) e a explicação (os comentários, explanatio) frisa o papel interpretativo da imagem, aquele que não se subordina as indicações textuais, mas faz uso delas para gerar outras reflexões.

${ }^{68}$ CAMPO HERNÁNDEZ, Alberto del; FREEMAN, Leslie G.; GONZÁLEZ ECHEGARAY, Joaquín (ed.). Beato de Liébana. Obras completas y complementarias. Edição bilíngue do latim ao castelhano. Madrid: Biblioteca de Autores Cristianos, 2004, v. 1, p. 46-47, tradução nossa. As passagens em itálico referem-se aos trechos do Apocalipse tomados por Beato de Liébana. No Beatus de Facundus, estes trechos aparecem como rubricas.

${ }^{69}$ CAMPO HERNÁNDEZ, Alberto del; FREEMAN, Leslie G.; GONZÁLEZ ECHEGARAY, Joaquín (ed.). Beato de Liébana. Obras completas y complementarias. Edição bilíngue do latim ao castelhano. Madrid: Biblioteca de Autores Cristianos, 2004, v. 1, p. 446-447, tradução nossa.

70 WILliamS, John. The illustrated Beatus: a corpus of the illustrations of the Commentary on the Apocalypse. London: Harvey Miller, 1994, v.1, p. 120. 
Em sua literalidade, as ilustrações do Apocalipse, e aquelas de Daniel, são recapitulações dos textos bíblicos. Elas podem servir como 'rubricas pictóricas', um prestativo guia para uma storia particular, se não a sua interpretação; elas até podem, podemos imaginar, tomar o lugar da própria passagem para um espectador informado ${ }^{71}$

Como "rubricas pictóricas", as imagens se aproximam de uma interpretação que mais que representar, presentifica as visões de São João, o intangível no visível. Trata-se de interpretação textual em imagem, de narrativa pictórica dentro de seu próprio domínio, com suas especificidades. Assim como a imagem participa no ritmo da leitura, aquilo que Mary Carruthers $^{72}$ chama de painéis indicadores, elementos que norteiam a leitura, marcam início, final de textos e passagens importantes, as quais o leitor deve estar mais atento. Podemos mesmo pensar em uma orientação rápida ao conteúdo do códice e, de modo ambivalente, um aprofundamento que exige reflexão e maior tempo dispensado ao entendimento de sua linguagem (meditatio).

Não apenas o texto do Apocalipse (storia) é acompanhado de imagens, mas também alguns fragmentos da explanatio são recapitulados em imagem. São essas a imagem do Mapamúndi, da Arca de Noé, da Palmeira dos justos, da Raposa e o Galo e duas imagens relacionadas ao Livro de Daniel (as Quatro bestas de Daniel e a Estátua com cabeça de ouro).

Em geral, as imagens são apresentadas de três formas: (i) inscritas diretamente sobre a superfície da página, (ii) com borda e um campo de cor monocromático (iii) ou com borda e bandas de fundo coloridas. ${ }^{73}$ Não há uma constância entre o uso de um ou outro modo de apresentação das imagens na página. Um mesmo manuscrito pode possuir os três modos, como no caso do Beatus de Facundus, ou apenas um deles, ou mesmo não possuir imagens. ${ }^{74}$ A escolha poderia, por exemplo, ser guiada a depender do modelo usado para a cópia ou mesmo do valor econômico destinado à feitura do manuscrito. Um investimento econômico

\footnotetext{
71 WILLIAMS, John. The illustrated Beatus: a corpus of the illustrations of the Commentary on the Apocalypse. London: Harvey Miller, 1994, v.1, p. 120, tradução nossa.

72 CARRUTHERS, Mary. The Medieval Craft of Memory: An Anthology of Texts and Pictures. Estados Unidos: University of Pennsylvania Press, 2002, p. 153.

${ }^{73}$ Como não faremos um estudo mais aprofundado das imagens nesta parte do trabalho, ver no site da Biblioteca Nacional da Espanha os seguintes fólios: f. 70v para (i) ou demais imagens a partir do f. 268v; f. 6, f. 17 e f. 214 para (ii) e f. 7v, f. 41 e outros para (iii) no Beatus de Facundus. Disponível em: <http://bdhrd.bne.es/viewer.vm?pid=d-1806167>. Acesso em: 25 nov. 2015.

${ }^{74}$ Há quatro códices que não possuem imagens: Beatus de Poblet (séc. XII), Beatus de Alcobaça (séc. XIII), Beatus de Placensia (1552) e Beatus de Marques de Vélez (séc. XVI). E outros seis fragmentos de cópias: três deles datados do século X, dois do século XI e um fragmento não miniado do inicio do século XII (Anexo C).
} 
maior abre a possibilidade de uma maior gradação de cores, de uso de materiais como ouro e de um maior número de imagens.

Quanto à questão dos modelos, os estudos de Sanders ${ }^{75} \mathrm{e}$, posteriormente, de Neuss, ${ }^{76}$ ambos do início da década de 1930, propuseram uma sistematização das cópias dos Beati. Sanders classificou-as em grupos de acordo com aproximações e variações textuais. Neuss fez uso desses grupos e comparou as variações textuais com variações imagéticas para propor um stemma codicum - uma tábua genealógica dos manuscritos pertencentes a uma mesma obra (Anexo C). ${ }^{77}$ Os estudos de Neuss, apesar de abordarem minimamente a presença das imagens, dedicaram-se em sua maior parte à tradição textual e suas transmissões. Em 1976, Peter Klein propôs um novo stemma codicum (Anexo C), o qual argumentava uma nova organização filológica dos manuscritos, de acordo com a tradição pictórica dos Beati. ${ }^{78}$ John Williams também dedicou sua atenção às imagens, com um novo stemma, na revisão dois anteriores (Anexo C). ${ }^{79}$ Tanto na proposta de Neuss, quanto na de Klein e na de Williams, as cópias dividem-se em duas famílias. A primeira família distingue-se pela ausência de elementos da segunda: a presença de tábuas genealógicas (que comentaremos a seguir), do

\footnotetext{
75 SANDERS, H. A. Beati in Apocalypsin libri duodecim. Roma: Papers and monographs of American Academy in Rome, II, 1930.

${ }^{76}$ NEUSS, Wilhelm. Die Aokalypse des HI. Johannes in der altspanischen Bibel-Illustration: Das Problem der Beatus Handschriften. 2 v. Alemanha: Bonn-Münster, 1931.
}

77 POULIQUEN, Marc Le. Using lattices for reconstructing stemma. Fifth international conference on concept lattices and their applications, Montpellier, 24-26 octobre 2007. Disponível em: <http://ceur-ws.org/Vol331/Le_Pouliquen.pdf>. Acesso em: 15 dez. 2015

${ }^{78}$ KLEIN, Peter. La tradición pictórica de los beatos. Actas del Simposio para el estudio de los códices del Comentario al Apocalipsis de Beato de Liébana, II. Madrid: Joyas Bibliográficas, 1980, p. 83-115. Ver também os estudos de Klein sobre a cópia laurbanense: KLEIN, Peter. Beato de Liébana: la ilustración de los manuscritos de Beato y el Apocalipsis de Lorvão. Trad. Beatriz Mariño. Valência: Patrimonio Ediciones, 2004.

${ }^{79} \mathrm{Na}$ revisão dos stemmas, Williams indica algumas contradições dos anteriores. Como no caso de Sanders baseia as diferenciações das cópias, sem grandes argumentações, segundo Williams, a partir de três protótipos diferentes da obra de Beato de Liébana, executados em 776, 784 e 786, em que a primeira edição compilada por Beato de Liébana a ser iluminada, provavelmente, seria o de 784. Peter Klein e John Williams concordam que o protobeato, o primeiro Beato iluminado, deveria depender de alguma cópia iluminada do Comentário de Ticônio ou Primasio, de origem norteafricana, que deveria existir na biblioteca de Liébana. Durante o processo de pesquisa não adentramos na discussão sobre as origens do modelo, quantas edições existiriam, se eram ou não iluminadas, pois, apesar de argumentações bem desenvolvidas por Williams, a origem da cópia não seria um dado completamente alterador dos funcionamentos da imagem. A maior contribuição de Williams para nosso trabalho está na disponibilização de todas as imagens presente em todos os Beati iluminados até então conhecidos pela obra "The illustrated Beatus: a corpus of the illustrations of the Commentary on the Apocalypse" (1994-2003), em cinco volumes. Além das imagens, encontramos no trabalho de Williams as inscrições contidas em cada miniatura, visto que as imagens fornecidas pela edição dos cinco volumes nem sempre permitem a legibilidade do texto. A obra também fornece informações como o local de feitura das cópias, datações, usos possíveis da cópia, o trabalho dos iluminadores, dos escribas, as correntes estilísticas (como a tradição pictórica moçárabe e a herança carolíngia), as filiações entre os manuscritos, dentre outras informações. WILLIAMS, John. The Beatus Text. In: The illustrated Beatus: a corpus of the illustrations of the Commentary on the Apocalypse. London: Harvey Miller, 1994-2003, v. 1, p. 19-30. 
Comentário ao livro de Daniel e as imagens pertencentes a esse livro, bem como o acréscimo de outras imagens - ciclo dos evangelistas, a Arca de Noé, o Mapa-múndi e a Palmeira dos Justos - e algumas variações textuais apontadas por Sanders e Neuss.

Apesar de essas categorizações serem importantes dentro da bibliografia dos Beati, não vamos adentrar especificamente nas discussões dos stemmas propostos por Neuss, Klein e Williams porque exigiria um trabalho dedicado à filologia das cópias, o que se estende além dos nossos interesses específicos na discussão do ornamento. Frisamos que a revisão bibliográfica sobre as famílias dos Beati foi importante para conhecer o manuscrito do Beatus de Facundus dentro de uma série maior, pois é pela comparação que se observam os componentes básicos para que um manuscrito seja considerado de uma família. ${ }^{80}$

Além do prefácio, os dois prólogos, a interpretação e o texto do próprio Comentário ao Apocalipse (storia - imagem - explanatio), outras partes da obra ajudam a construir a tradição dos Beati, ou seja, elementos recorrentes que permitem, juntos, identificar um manuscrito como uma das cópias do Comentário ao Apocalipse de Beato de Liébana. São eles: as tábuas genealógicas, o tratado De adfinitatibus et gradibus, de Santo Isidoro, e o Comentário ao livro de Daniel, por São Jerônimo.

Quando presentes, as tábuas genealógicas encontram-se no início do Beatus, lugar que também ocupavam, nas bíblias peninsulares, as grandes genealogias que iam desde Adão e Eva até a Virgem e Jesus. Nos Beati, as tábuas ocupam vários fólios, com figuras, esquemas e informações genealógicas de numerosos personagens bíblicos encerrados em estruturas circulares e arcos (similares às tábuas de cânones). Às vezes as tábuas aparecem nos primeiros fólios, outras, como no caso do Beatus de Facundus, após nove imagens iniciais nãoapocalípticas, isto é, que não têm relação direta com o texto do Apocalipse. As "Afinidades e Graus de Parentesco" dão nome ao tratado de Isidoro De adfinitatibus et Gradibus, uma

\footnotetext{
${ }^{80}$ Além disso, o uso dos stemmas durante a pesquisa nos permitiu fazer comparações pontuais com outras cópias, que eram mais próximas ao Beatus de Facundus. Mesmo que neste espaço dissertativo não tracemos estes comparativos, eles foram chaves importantes para o processo. Utilizamos como referência o stemma usado por Bolman, que não se trata de um novo stemma propriamente dito, mas a união dos trabalhos de Peter Klein e John Williams: BOLMAN, Elizabeth S. De coloribus: the meanings of color in Beatus manuscripts. Gesta, vol. 38, $\mathrm{n}^{\circ}$. 1, p. 22-34, 1999, p. 23. (Anexo C). Também excluímos deste trabalho as classificações das cópias segundo a ideia de estilo, que seguem as divisões dos Beati em duas famílias. Por considerarmos esse tipo de classificação um pouco perigosa, que pode ser mal interpretada se não for suficientemente extensa e detalhada, optamos por não adentrar em um assunto que não considera, necessariamente, o funcionamento das imagens. Classificações quando são reproduzidas em muitos trabalhos sem um aprofundamento adequado, podem sofrer de uma síndrome de "telefone sem fio", encadeada pela ideia de síntese. A cada nova síntese, parte dos argumentos são deixados de lado, até o ponto em que o "estilo" torna-se um ponto autossuficiente de aproximação ou distanciamento das cópias, sem que elas estejam ainda em comparação.
} 
adaptação de um capítulo das Etimologias (Livro IX, capítulo 5) que se ocupa dos grupos humanos, dos diferentes povos e de suas línguas. A partir do tratado são compostas duas imagens, um quadro de parentescos e uma árvore de consanguinidade. O tratado, quando existente nas cópias dos Beati, segue após o texto do Comentário ao Apocalipse. E, por fim, o último elemento que aparece em um Beatus, mas não em todos, é o Comentário ao livro de Daniel, por São Jerônimo (Hieronymi in Danielem), com seu caráter profético e referências ao Anticristo.

Em resumo, teríamos, um Beatus "ideal", quer dizer, o mais completo possível diante de todas as cópias, com a seguinte sequência de conteúdo: tábuas genealógicas, prefácio, prólogo I, prólogo II, Interpretatio, Comentário ao Apocalipse, De Adfinitatibus et Gradibus e Comentário ao livro de Daniel por São Jerônimo, junto das imagens referentes a cada passagem.

\subsection{O que nasceu no jardim da realeza}

Como parte da família dos Beati, o Beatus de Facundus é uma das cópias do Comentário ao Apocalipse do século VIII, de Beato de Liébana. Diferente das outras cópias, o livro copiado por Facundus, em 1047, foi uma encomenda real, e não monástica. Como veremos, esta diferenciação é importante na medida em que aproxima este objeto de outras encomendas de grande investimento econômico, feitas pelos mesmos comitentes, o casal real de Leão e Castela, Fernando I e Sancha.

Ao longo do texto, ressaltaremos as ligações entre a encomenda deste Beatus e os materiais empregados em sua feitura, mas por ora, atentemo-nos a estruturação do manuscrito sob o viés da codicologia. Existem algumas divergências quanto à abrangência do campo codicológico: se ele se restringe ao aspecto material do manuscrito ou se é entendido num 
sentido mais amplo, encerrando todos os aspectos relacionados, inclusive os históricoculturais. $^{81}$

Até o momento não lidamos com a localização do Beatus de Facundus no tempo e espaço, com suas particularidades contextuais, o que faremos ao longo do trabalho e mais especificamente no capítulo 3, segundo nosso interesse em um campo ampliado da Codicologia, que não se restringe à materialidade do objeto. A abordagem codicológica a seguir se detém na descrição das partes constitutivas do Beatus de Facundus, na formação dos cadernos, na atenção à Regra de Gregory, no processo de picotagem, de pautação, de justificação e em dados mais básicos sobre sua encomenda (comitentes, copista, miniaturista). No capítulo 3 ampliaremos as considerações codicológicas para uma contextualização histórica do reinado de Fernando I. ${ }^{82}$

A descrição da materialidade aqui proposta, que leva em consideração a codicologia, serve-nos como ferramenta para a visualização do manuscrito. Observamos que o pergaminho utilizado é de espessura variável, mas geralmente fino. O processo de picotagem segue uma prática própria dos scriptoria hispânicos, em que os piques não estão próximos à margem, mas partem do centro do fólio (Figura 6). A prática foi comum até o final do século XI, quando podemos ainda observar o uso no Beatus de Osma (1086). ${ }^{83}$

De um modo geral, tanto a preparação quanto a escrita são muito regulares em todo o códice. Diferenciam-se apenas nos primeiros fólios (ff. 6-17v), que não possuem pautações, visto que não foram preparados para receberem texto, e sim as imagens iniciais e as tábuas genealógicas. Do f.18 ao f. 57v a pautação é regular, com 36 linhas, com a última linha não utilizada para escrita. Nos fólios restantes, a pautação é de 35 linhas, o que significa que

\footnotetext{
${ }^{81}$ RUIZ GARCÍA, Elisa. Manual de codicología. Salamanca: Fundación Germán Sánchez Ruipérez; Madrid: Pirámide, 1988.

${ }^{82}$ Quando a análise codicológica não se limita ao material e recorre a especificidades também do texto e do conteúdo da obra, recorre-se à paleografia. Contudo, devido à natureza desta pesquisa, não nos aprofundaremos em questões paleográficas, mas encontramos respaldo no projeto "Internet History Sourcebooks", que tem como editor Paul Halsall, o qual afirma que a Codicologia é "[...] o estudo dos manuscritos como objetos e não como textos. Investigando sua criação [...] e história". Disponível em: 〈http://www.fordham.edu/Halsall/index.asp〉. Acesso em: 10 out 2014. Destaque para HALSALL, Paul. Glossary of Terms Used in Paleography: preliminary version 0.2. In: __ Byzantium: The Byzantine Studies on the Internet. New York: Fordham University, 21 out. 1996. Disponível em: <http://www.fordham.edu/halsall/byz/paleoggloss.html〉. Acesso em: 19 out. 2014. Outra ferramenta útil na pesquisa codicológica: MUZERELLE, Denis Vocabulaire codicologique: répertoire méthodique des termes français relatifs aux manuscrits. Paris: Ed. CEMI, 1985, p. 265. Disponível em: <http://vocabulaire.irht.cnrs.fr>. Acesso em: 19 out 2014.
}

${ }^{83}$ SÁNCHEZ MARIANA, Manuel. La tradición de los Beatos y el Beato de Fernando I y Sancha. In: WILLIAMS, John et al. Beato de Fernando I y Sancha. Barcelona: M. Moleiro, 2006, p. 51. 
mesmo nos fólios anteriores, quando há mais uma linha, segue-se o padrão de 35 linhas para escrita.

Além das linhas delimitadas pela picotagem, há, na página, as linhas verticais e horizontais que delimitam o espaço destinado à escrita - a caixa de texto - formadas pelo processo de justificação. A justificação, assim como as linhas da pauta, é visível, marcada a ponta seca. A incisão foi feita com tamanha força que em determinados pontos perfurou o pergaminho. Outros rasgos que podem vir da preparação ou encadernação, mas que podem também não ser da época de feitura, foram costurados (ff. 18, 34, 44, 45 e 51). ${ }^{84}$

O plano da página divide o texto em duas colunas da seguinte maneira:

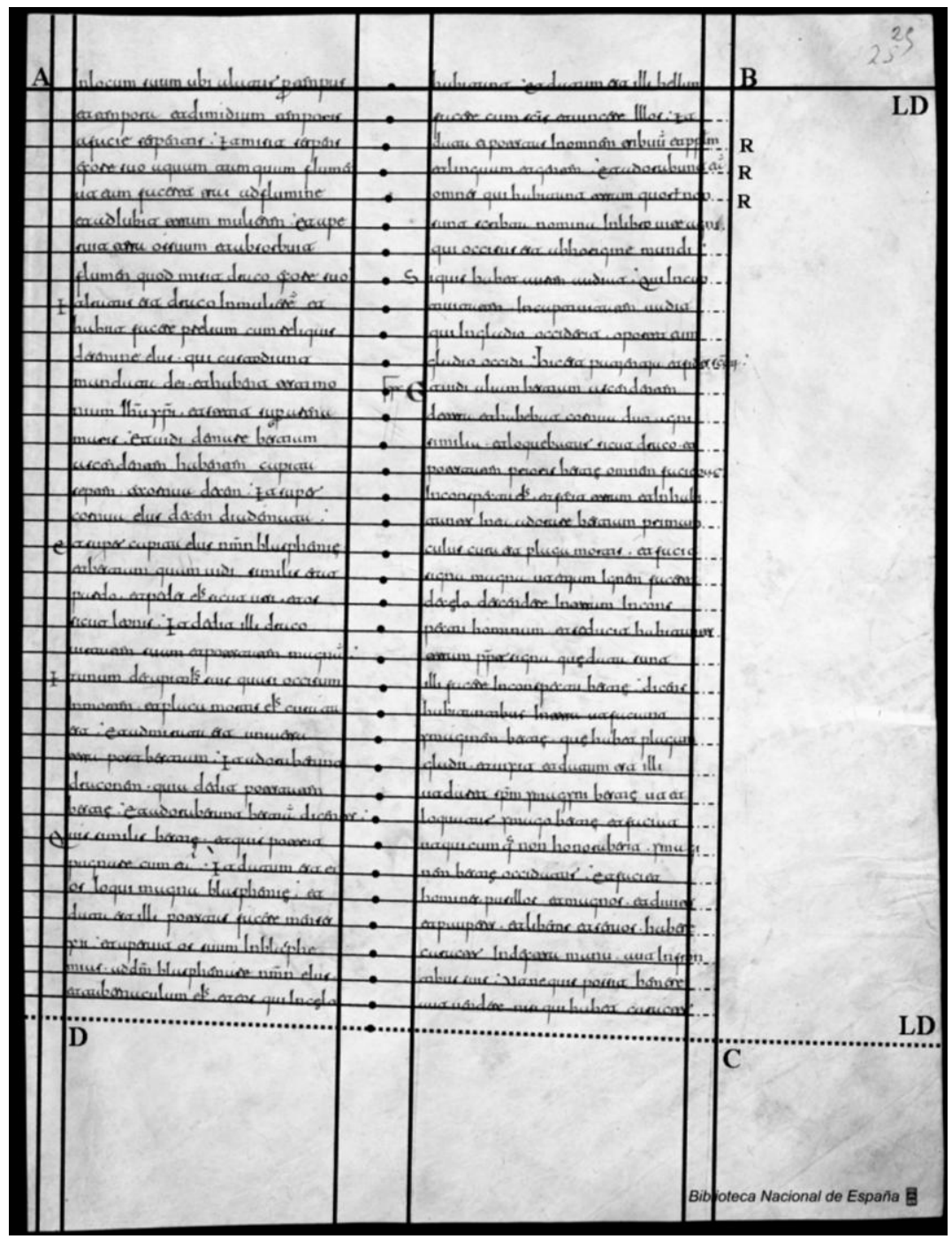

Figura 4. Beatus de Facundus, f.25, plano de página. Fonte: www.bne.es [alterações da autora]

${ }^{84}$ SÁNCHEZ MARIANA, Manuel. La tradición de los Beatos y el Beato de Fernando I y Sancha. In: WILLIAMS, John et al. Beato de Fernando I y Sancha. Barcelona: M. Moleiro, 2006. p. 51. 
O quadro de justificação que delimita o espaço do texto na página é formado pelas linhas de junção entre os pontos A, B, C e D, assinalados na Figura 5. Essas linhas, que delimitam a justificação, são chamadas de linhas justificantes (AB, BC, CD, DA). Na parte superior e inferior encontramos as linhas diretrizes (LD), que se distinguem das linhas ordinárias (R), aquelas que delimitam a largura da justificação, por se prolongarem até mais próximo da margem da página. Não é o caso do Beatus de Facundus, mas as linhas diretrizes também podem ser encontradas no meio da página.

A justificação divide a página em duas colunas, uma de $83 \mathrm{~mm}$ e outra de $80 \mathrm{~mm}$, separadas por um espaço de $23 \mathrm{~mm}$. O espaço entre as linhas é de $7 \mathrm{~mm}$. Essas medições são fornecidas por John Williams, mas não concordamos totalmente com a representação que usa para a delimitação das linhas na página.

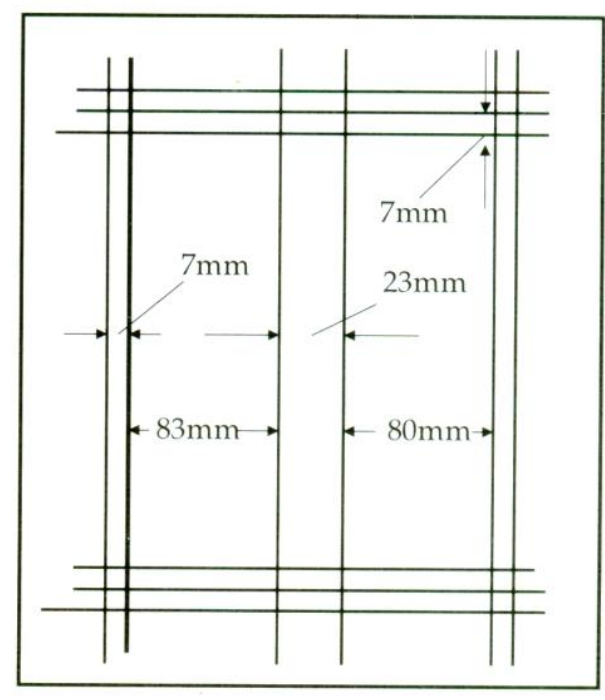

Figura 5. Beatus de Facundus, plano de página (Williams).

Fonte: John Williams, 1994-2003 ${ }^{85}$

O esquema proposto por ele apresenta três linhas de diretrizes (LD) na parte superior e três na inferior. Contudo, no Beatus de Facundus observamos apenas duas linhas diretrizes, uma superior e outra inferior. A linha inferior só aparece entre os ff. 18 ao 57v, é a $36^{\mathrm{a}}$ linha que não recebe escrita. Nos outros fólios, ela não aparece e a última linha, a $35^{\mathrm{a}}$, mantém-se nos limites da justificação. Todas as linhas horizontais, sejam ordinárias ou diretrizes,

85 WILLIAMS, John. The illustrated Beatus: a corpus of the illustrations of the Commentary on the Apocalypse. London: Harvey Miller, 1994-2003, v. 3, p. 38. 
prolongam-se na margem interna até a extremidade do fólio. Independente do esquema utilizado para visualizar a pautação, é sempre bom frisar que se trata de uma ferramenta de simplificação. O esquema que propomos utiliza a própria página do manuscrito como suporte e expõe as variações através de linhas pontilhadas.

O texto se mantém dentro dos quadros de justificação, exceto nos poucos casos em que se ultrapassa essa margem, como em algumas rubricas. O texto é copiado em escrita visigótica, a que é usada nos códices copiados em Leão e Castela por volta do século XI, antes da adoção dos ritos romanos e da letra carolíngia. Quanto à escrita e às abreviações, Sánchez Mariana afirma que

[...] nosso códice representa uma série de características próprias da primeira metade do século XI: regularidade e uniformidade no traçado, perfeita separação das palavras, abreviações e signos de pontuação usuais. As formas das letras não se distanciam do habitual, com duas formas de $d$ (uncial e minúscula), distinção entre a $i$ dental, o $j$ sibilante, o $y$ semivocálico e breve ('ayt', etc.), com uso variável do $I$ maiúsculo, às vezes também com caráter semivocálico (IeIunando', etc.). As abreviações também correspondem a época: $s$ sobreposto para a terminação $u s$, e

caudado para ae, 2 para abreviar pra, prae, pre ou pro, traço ou traço e ponto sobreposto para a contração, etc.; são frequientes as letras sobrepostas para os numerais romanos. O signo de pausa com a vírgula acima e o ponto abaixo é o mais frequente através de todo o códice, simplesmente para separar frases ou como fim de parágrafo, embora se use também o ponto final; o signo de interrogação se usa somente em algumas ocasiões. ${ }^{86}$

$\mathrm{Na}$ escrita do texto são utilizadas duas cores, marrom em tom escuro e vermelha. $\mathrm{O}$ marrom era usado para o texto em geral e o vermelho (rubrica) para epígrafes, iniciais, números, palavras iniciais de parágrafo, frases destacadas. Em determinadas partes do texto há também palavras escritas em vermelho, que não parecem se encaixar nesses usos citados, ou seja, palavras que comumente não receberiam destaque por conta de seu conteúdo e localização. Para essa presença, Sánchez Mariana explica a possibilidade de estas palavras serem estranhas ao copista, "[...] dando às vezes a impressão de que palavras pouco legíveis no original teriam sido deixadas em branco e logo preenchidas em vermelho sem um sentido determinado". 87

\footnotetext{
${ }^{86}$ SÁNCHEZ MARIANA, Manuel. La tradición de los Beatos y el Beato de Fernando I y Sancha. In: WILLIAMS, John et al. Beato de Fernando I y Sancha. Barcelona: M. Moleiro, 2006, p. 54-55, tradução nossa.

${ }^{87}$ SÁNCHEZ MARIANA, Manuel. La tradición de los Beatos y el Beato de Fernando I y Sancha. In: WILLIAMS, John et al. Beato de Fernando I y Sancha. Barcelona: M. Moleiro, 2006, p. 55, tradução nossa.
} 
O Beatus de Facundus é formado por 39 cadernos. Com exceção dos dois primeiros cadernos, o último e o de número 33, todos são quaternos (quatro bifólios, oito fólios).

Na observância da Regra de Gregory, nomeamos a face de Pelo como "P" e a face de Carne como "C" (Quadro 1). Na nossa aplicação da Regra partimos da face de Pelo, presente no primeiro fólio do manuscrito, f.6, e montamos uma sequência para um quaterno ideal, ou seja, em que a face de Pelo $(\mathrm{P})$ coincide com face de Pelo $(\mathrm{P})$ e face de Carne $(\mathrm{C})$ encontra face de Carne (C): "PC CP PC CP | PC CP PC CP". É possível observar que algumas partes do manuscrito não atende a Regra, onde a frente Pelo não encontra com outra face de Pelo, mas sim de Carne, ou vice e versa. No Quadro 1, essas alterações são marcadas graficamente em fonte maior, negrito e por um sublinhado.

Através da observação dos fólios, percebe-se que os encontros da face Pelo com face Carne podem significar mais que um arranjo, ou montagem, errado, e sim a falta de um fólio.

A primeira violação à Regra de Gregory é o encontro do f.11v de face Pelo (Caderno 1) com o f.12 de face Carne (Caderno 2). Não se trata, segundo Sánchez Mariana, de uma ausência de fólio, visto que o texto das tábuas genealógicas está completo. ${ }^{88} \mathrm{O}$ mesmo argumento valeria para a segunda discordância, entre os f.17v, de face Carne (caderno 2), e o f.18, de Face Pelo (caderno 3), contudo, o encontro marca o final das Tábuas genealógicas. Sánchez Mariana conjectura a ausência de uma folha entre o f.17 e f.18, e John Williams ${ }^{89}$ acrescenta que, se de fato falta uma folha em um dos fólios, estaria a representação do Pássaro e a Serpente em Combate ausente no Beatus de Facundus. ${ }^{90}$ A formação do caderno 2 contribui com a suspeita da falta de uma folha. Os ff 12 e 13 estão soltos e os ff.14/17 e 15/16 formam bifólios. $^{91}$

\footnotetext{
${ }^{88}$ SÁNCHEZ MARIANA, Manuel. La tradición de los Beatos y el Beato de Fernando I y Sancha. In: WILLIAMS, John et al. Beato de Fernando I y Sancha. Barcelona: M. Moleiro, 2006, p. 51.

${ }^{89}$ WILLIAMS, John. The illustrated Beatus: a corpus of the illustrations of the Commentary on the Apocalypse. London: Harvey Miller, 1994-2003, v. 3, p. 40.

${ }^{90}$ Essa imagem é encontrada no Beatus de Girona (f. 18v), Beatus de Rylands (f. 14), Beatus de Las Huelgas (f. 12v), Beatus de Saint-Sever (f. 13), Beatus de Urgell (f. Vv) e Beatus de Turin (f. 23).

${ }^{91}$ WILLIAMS, John. The illustrated Beatus: a corpus of the illustrations of the Commentary on the Apocalypse. London: Harvey Miller, 1994-2003, v. 3, p. 40.
} 


\begin{tabular}{|c|c|c|c|}
\hline Caderno $^{92}$ & Fólios & $\begin{array}{l}\text { Divisão dos } \\
\text { bifólios }\end{array}$ & Regra de Gregory \\
\hline 1 & $6-11$ & $3+3$ & PC CP PC $\mid$ СР PC C \\
\hline 2 & $12-17$ & $4+2$ & $\underline{\mathbf{C P}}$ PC CP РC $\mid \mathrm{CP}$ P $\overline{\mathbf{C}}$ \\
\hline 3 & $18-25$ & $4+4$ & РС СР РС СР | РC СР РC CP \\
\hline 4 & $26-33$ & $4+4$ & $\overline{\mathrm{PC}}$ СР РC CP $\mid$ РC CP РC CP \\
\hline 5 & $34-41$ & $4+4$ & \begin{tabular}{l|l} 
PC CP PC CP & PC CP PC CP
\end{tabular} \\
\hline 6 & $42-49$ & $4+4$ & PC CP РC CP $\mid$ PC CP РC CP \\
\hline 7 & $50-57$ & $4+4$ & РС СР РC СР $\mid$ РС СР РC СР \\
\hline 8 & $58-65$ & $4+4$ & $\begin{array}{l}\text { PC CP РC CP } \\
\text { PC CP РC CP }\end{array}$ \\
\hline 9 & $66-73$ & $4+4$ & PC CP PC CP $\mid$ PC CP РC CP \\
\hline 10 & $74-81$ & $4+4$ & РC СР РC СР $\mid$ РC СР РC СР \\
\hline 11 & $82-89$ & $4+4$ & 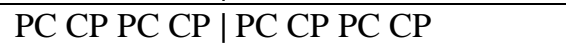 \\
\hline 12 & $90-97$ & $4+4$ & 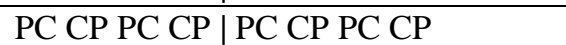 \\
\hline 13 & $98-105$ & $4+4$ & РС СР РС СР $\mid$ РC СР РC СР \\
\hline 14 & $106-113$ & $4+4$ & $\begin{array}{l}\text { PC CP PC CP } \\
\text { PC CP PC CP }\end{array}$ \\
\hline 15 & $114-121$ & $4+4$ & \begin{tabular}{l|l|l|l|} 
PC CP PC CP & PC CP PC CP
\end{tabular} \\
\hline 16 & $122-129$ & $4+4$ & РС СР РС СР $\mid$ РС СР РС СР \\
\hline 17 & $130-137$ & $4+4$ & $\begin{array}{l}\text { PC CP РC CP } \\
\text { PC CP РC CP }\end{array}$ \\
\hline 18 & $138-145$ & $4+4$ & \begin{tabular}{l|l|l|l|} 
PC CP PC CP & PC CP PC CP
\end{tabular} \\
\hline 19 & $146-153$ & $4+4$ & РС СР РС СР $\mid$ РС СР РС СР \\
\hline 20 & $154-161$ & $4+4$ & 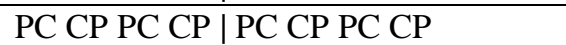 \\
\hline 21 & $162-169$ & $4+4$ & PC CP PC CP $\mid$ PC CP РC CP \\
\hline 22 & $170-177$ & $4+4$ & РC СР РC СР $\mid$ РC СР РC CP \\
\hline 23 & $178-185$ & $4+4$ & \begin{tabular}{l|l|l|} 
РС СР РC СР & РС СР РC CP
\end{tabular} \\
\hline 24 & $186-193$ & $4+4$ & PC CP PC CP $\mid$ PC CP РC CP \\
\hline 25 & 194-201 & $4+4$ & РC СР РC СР $\mid$ РC СР РC CP \\
\hline 26 & $202-209$ & $4+4$ & 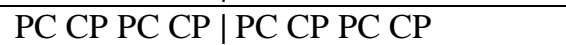 \\
\hline 27 & $210-217$ & $4+4$ & PC CP PC CP | PC CP PC CP \\
\hline 28 & $218-225$ & $4+4$ & РC CP РC СР $\mid$ РC СР РC CP \\
\hline 29 & $226-233$ & $4+4$ & $\begin{array}{l}\text { PC CP PC CP } \\
\text { PC CP PC CP }\end{array}$ \\
\hline 30 & $234-241$ & $4+4$ & PC CP PC CP | PC CP PC CP \\
\hline 31 & $242-249$ & $4+4$ & PC CP PC CP $\mid$ PC CP РC CP \\
\hline 32 & $250-257$ & $4+4$ & PC CP PC CP | \\
\hline 33 & $258-267$ & $(4+6)$ & РС СР РС СР | РС СР Р $\underline{\mathbf{C}} \underline{\mathbf{P C}}$ С $\underline{\mathbf{P}} \underline{\mathrm{CP}}$ \\
\hline 34 & $268-275$ & $4+4$ & РC СР РC CP | \\
\hline 35 & $276-282$ & $3+4$ & PC CP PC | \\
\hline 36 & $283-290$ & $4+4$ & PC CP PC CP $\mid$ PC CP PC CP \\
\hline 37 & $291-298$ & $4+4$ & PC CP PC CP | PC CP PC CP \\
\hline 38 & $299-306$ & $4+4$ & \begin{tabular}{l|l|l|} 
PC CP PC CP & PC CP PC CP
\end{tabular} \\
\hline 39 & $307-316$ & $5+5$ & РC СР РC СР РC $\mid$ СР РC СР РC СР \\
\hline
\end{tabular}

Quadro 1. Beatus de Facundus, formação dos cadernos. Fonte: Elaborado pela autora ${ }^{93}$

\footnotetext{
${ }^{92}$ Alguns autores, como Sánchez Mariana, numeram os cadernos segundo a numeração presente no próprio manuscrito (nas assinaturas, quire-signature), aquela que auxilia na montagem. No Beatus de Facundus, os dois primeiros cadernos, que incluem imagens de página inteira e as tábuas genealógicas, não possuem assinaturas. Desse modo, a numeração só se inicia a partir do f. 18 e os cadernos precedentes são nomeados, por Sánchez Mariana, como A (ff. 6-11) e B (ff. 12-17). SÁNCHEZ MARIANA, Manuel. La tradición de los Beatos y el Beato de Fernando I y Sancha. In: WILLIAMS, John et al. Beato de Fernando I y Sancha. Barcelona: M. Moleiro, 2006, p. 53. Optamos por iniciar a contagem dos cadernos pelo início do manuscrito, no f. 6, na exclusão dos fólios das tábuas genealógicas, os quais não pertencem originalmente ao Beatus de Facundus.

${ }^{93}$ Para parte da estruturação do quadro, baseamo-nos em dados fornecidos por Sánchez Mariana quanto à divisão dos bifólios, coluna 2. SÁNCHEZ MARIANA, Manuel. La tradición de los Beatos y el Beato de Fernando I y Sancha. In: WILLIAMS, John et al. Beato de Fernando I y Sancha. Barcelona: M. Moleiro, 2006, p. 53.
} 
Ainda sobre este grupo inicial de cadernos, a Regra de Gregory, junto da observação da composição das imagens e do texto, mostra-se como um indício importante na indicação de fólios faltantes. Entre os ff. 7v-10 temos o ciclo dos evangelistas, uma sequência de 6 miniaturas de página inteira que representa os evangelistas, os anjos que portam o evangelho e a representação de cada um dos quatro signos tetramórficos. ${ }^{94}$ As representações de São Mateus (ff. 7v-8) e de São Marcos (ff. 8v-9) ocupam dois fólios cada, enquanto as de Lucas e João, apenas um fólio cada. Essa diferença faria supor, a princípio, a falta de dois fólios, mas é preciso observar as imagens atentamente (Figuras 6, 7 e 8). ${ }^{95}$

Sánchez Mariana não fornece a divisão dos bifólios no caderno 33, mas encontramos respaldo na proposta de John Williams, que divide os fólios segundo a seguinte ordem: 258-259-260-261 | 262-263-264-265-266-267. WILLIAMS, John. The illustrated Beatus: a corpus of the illustrations of the Commentary on the Apocalypse. London: Harvey Miller, 1994-2003, v. 3, p. 39.

${ }^{94}$ Os tetramorfos são representações iconográficas que simbolizam os evangelistas e que fazem referência a uma passagem do livro de Ezequiel: "Quanto à aparência dos seus rostos, os quatro tinham rosto de homem, rosto de leão no lado direito, rosto de boi no lado esquerdo, e rosto de águia" (Ezequiel, 1,10). Desse modo, o leão representa São Marcos, o Anjo representa São Mateus, a águia São João, e o touro refere-se a São Lucas. Sobre a representação dos tetramorfos Ver MARTíN, Esperanza Manso; SÁNCHEZ-RUBIO, María Ascensión S. Orígenes y fuentes de la iconografía del Tetramorfos en la pintura románica castellano-leonesa. Cuadernos de Arte e Iconografia, tomo II, $\mathrm{n}^{\mathrm{o}}$ 3, 1989, pp. 110-116. Disponível em: <http://www.fuesp.com/revistas/pag/cai0314.html>. Acesso em: 10 jul 2014; HERNANDO, Irene González. El tetramorfo. Revista Digital de Iconografoa Medieval, vol. III, n.5, p. 61-73, 2011. Disponível em: <https://www.ucm.es/data/cont/docs/621-2013-11-21-8.\%20Tetramorfo.pdf>. Acesso em: 14 jul. 2014.

95 Para a visualização das imagens em maiores detalhes, ver em: <http://bdh-rd.bne.es/viewer.vm?pid=d1806167>. Acesso em: 25 nov. 2015. 

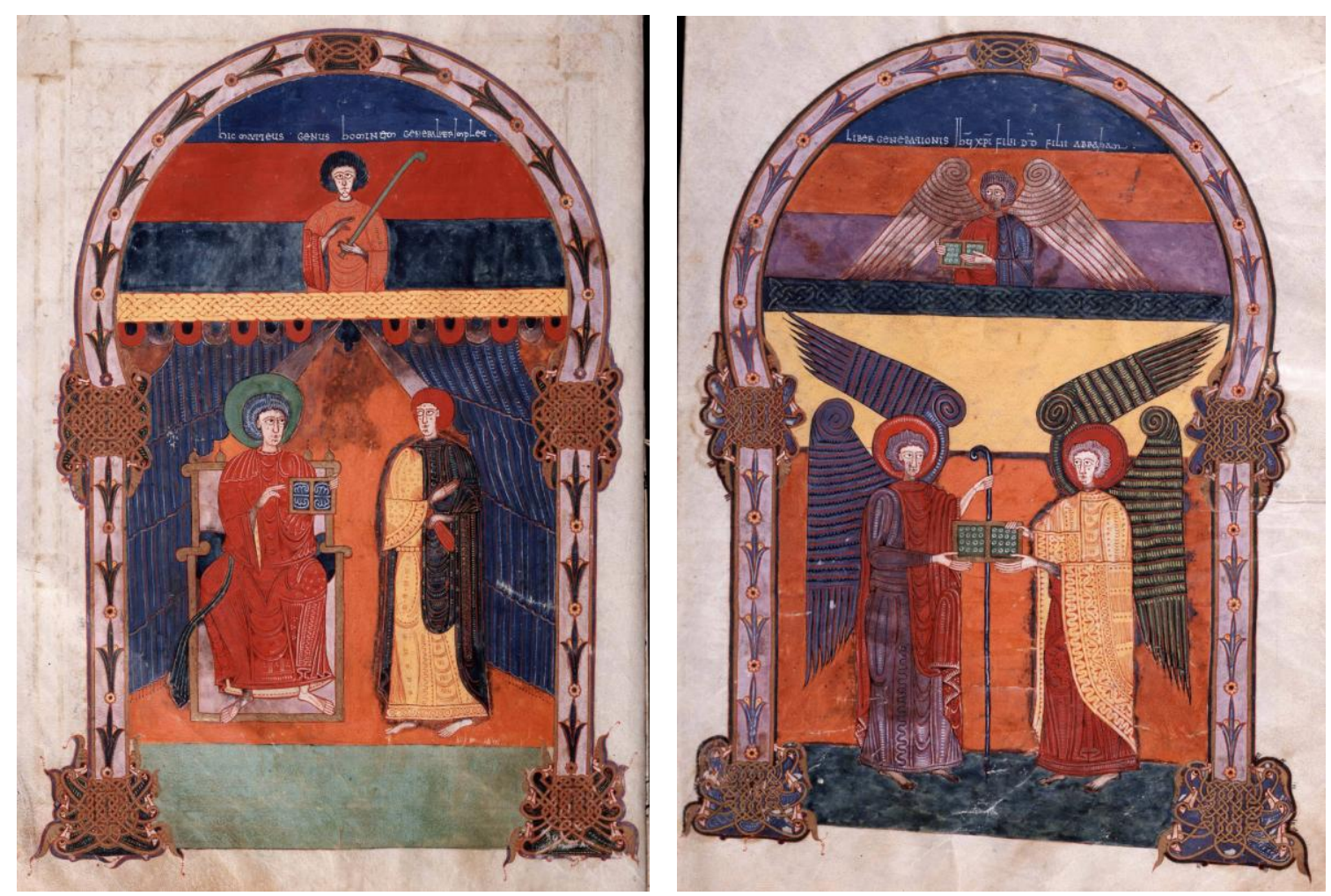

Figura 6. Beatus de Facundus, ff. 7v-8, ciclo dos evangelistas.

F. 7v - Mateus; f. 8 - Mateus e o Anjo

Fonte: www.bne.es
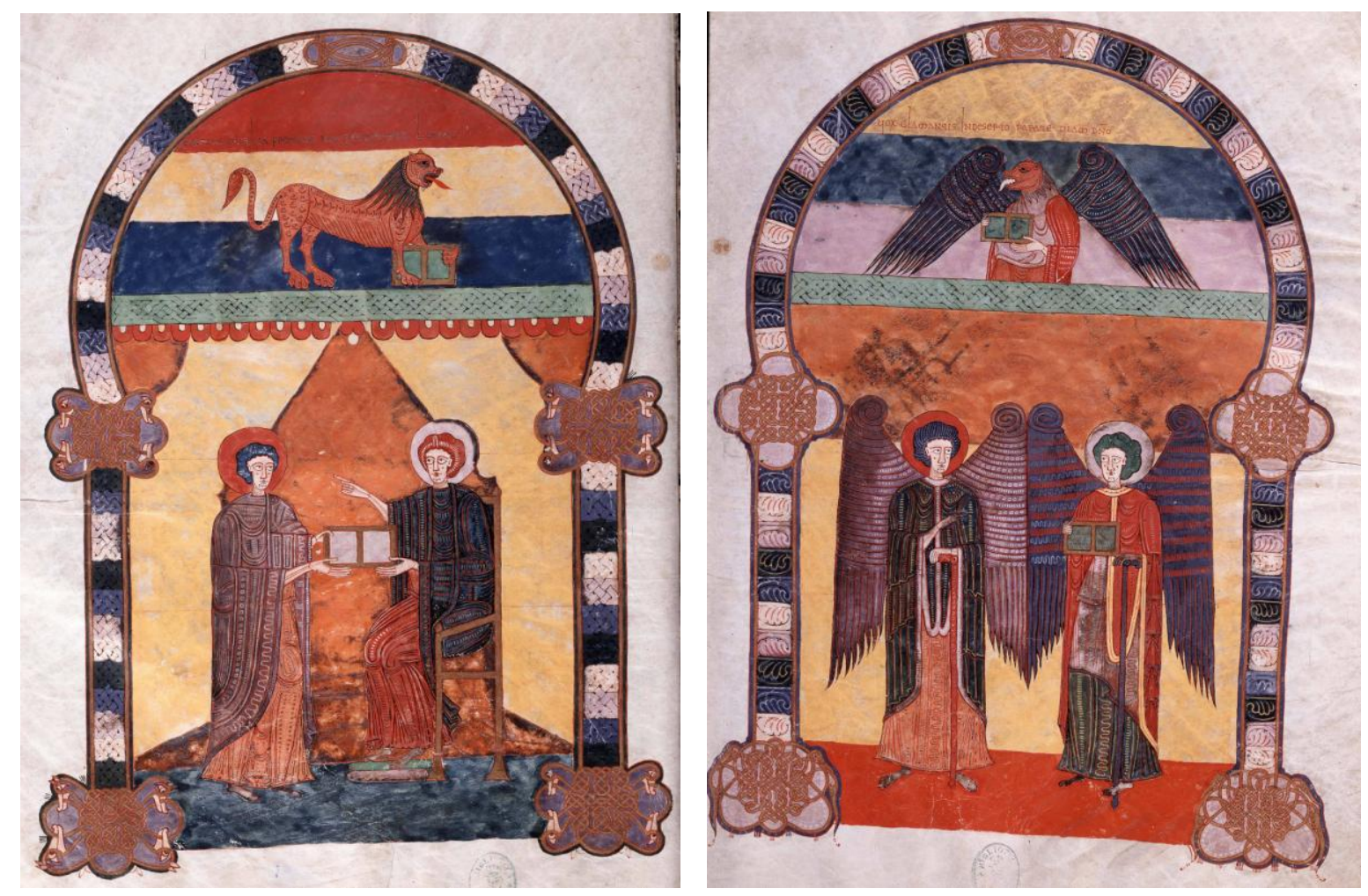

Figura 7. Beatus de Facundus, ff. 8v-9, ciclo dos evangelistas.

F. 8v - Marcos; f. 9 - Marcos e o Anjo.

Fonte: www.bne.es 

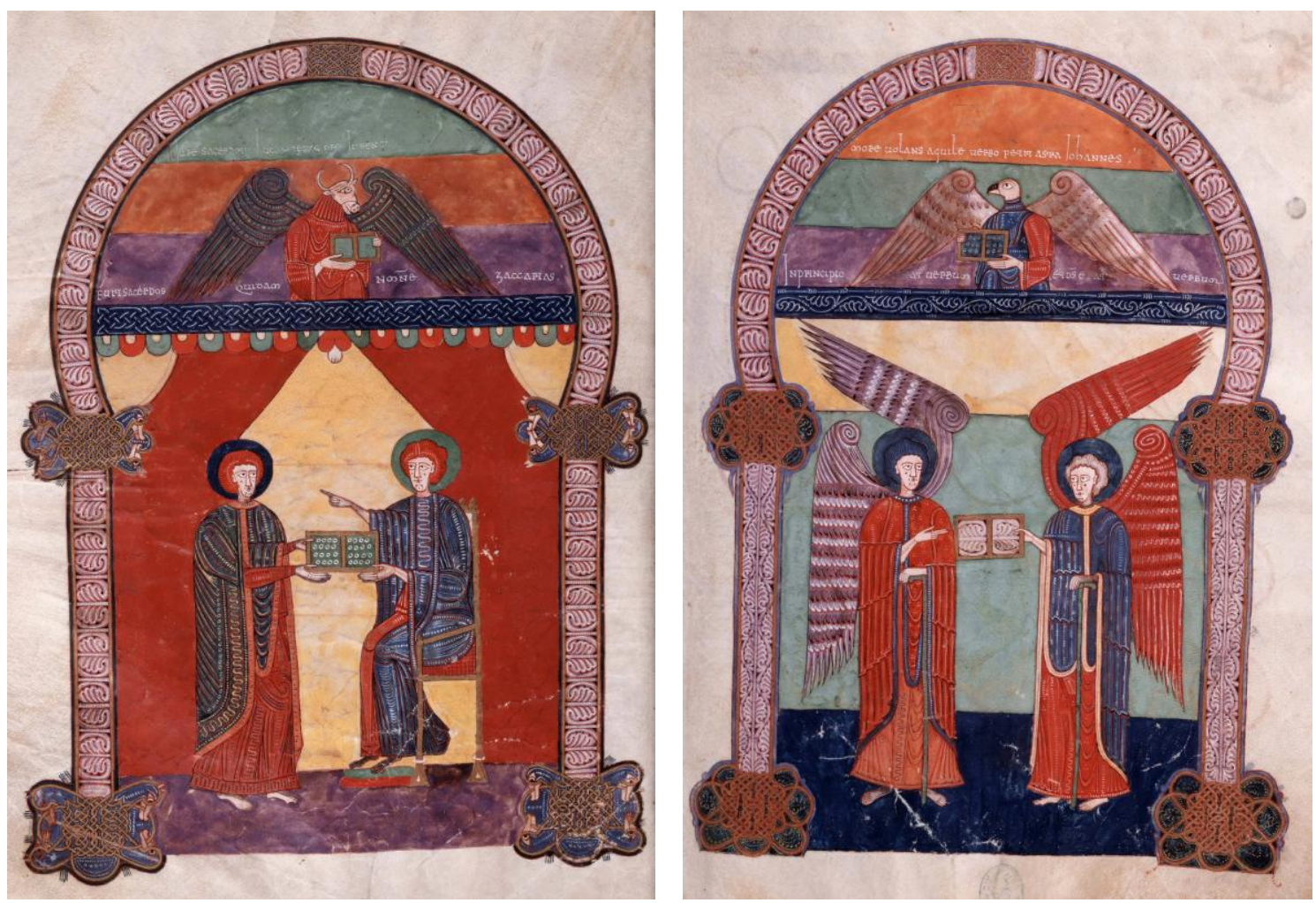

Figura 8. Beatus de Facundus, ff. 9v-10, ciclo dos evangelistas.

F. 9v - Lucas; f. 10 - João e o Anjo

Fonte: www.bne.es

$\mathrm{Na}$ imagem do f.7v, a cena é enquadrada, sobre a página, por um arco e colunas ornamentadas sob os quais o evangelista Mateus aparece sentado em um trono com o evangelho nas mãos. Na parte superior da imagem, protegida pelo arco, temos o personagem simbólico, correspondente ao evangelista. O personagem-símbolo de Mateus carrega um báculo, ou cajado, ao invés do livro da Revelação. Sobre ele a frase "Hic Matteus genus hominem generaliter implet", frase de Sedúlio, poeta cristão do século V, que, segundo Yarza Luaces, alude ao aspecto humano do signo. ${ }^{96} \mathrm{~A}$ inscrição reforça esse aspecto e intensifica a distância da imagem do fólio seguinte, f. 8, a de um anjo alado, acompanhado de dois anjos, que seguram o evangelho, e na parte superior a imagem angelical de Mateus, na qual se pode ler o começo do evangelho de Mateus "Liber generationis Ihesu Xhristi filii David, filii Abraham". ${ }^{97}$ A ornamentação das duas imagens, que se colocam uma de frente à outra, é semelhante, principalmente nas colunas e no arco. Além das mudanças entre os personagens e

\footnotetext{
${ }^{96}$ YARZA LUACES, Joaquín. Las miniaturas. In: WILLIAMS, John et al. Beato de Fernando I y Sancha. Barcelona: M. Moleiro, 2006, p. 99.

${ }^{97}$ YARZA LUACES, Joaquín. Las miniaturas. In: WILLIAMS, John et al. Beato de Fernando I y Sancha. Barcelona: M. Moleiro, 2006, p. 102.
} 
seus objetos, como o trono e o próprio evangelho, a diferença mais notável entre as duas imagens é a presença de uma cortina, que se mostra como a revelação (revelatio) na imagem onde o evangelista aparece com o evangelho.

O mesmo padrão compositivo é adotado nos dois fólios que ocupam a representação de São Marcos, apesar o evangelista ter trocado de lado. Antes Mateus ocupava o lado esquerdo da imagem, e agora, Marcos está à direita no f.8v. No primeiro, temos o evangelista sentado ao trono e na parte superior um leão que segura o livro. Sobre ele, a inscrição "Marcus ut alta fremens vox per deserta leonis", texto também de Sedúlio, que menciona o início do evangelho e o forte rugido do leão. ${ }^{98} \mathrm{Na}$ imagem do f.9, que aparece ao lado da imagem do f.8v quando o livro está aberto, temos os anjos e o evangelho de São Marcos. Na parte superior, abaixo do arco, a imagem do personagem simbólico, com cabeça de leão, corpo humano e asas angelicais, porta um livro dourado. A inscrição acima do anjo é o terceiro versículo do evangelho de Marcos "Vox clamantis in deserto parate viam d(omi)no".99

O jogo de correspondência entre as imagens, tanto figurativo quanto de ornamentação, faz supor que nas representações seguintes, de Lucas e João, ocorreria o mesmo: na primeira imagem com o evangelista e o animal na parte superior e, na segunda, com os anjos que portam o evangelho e o signo tetramórfico. Contudo, Lucas e João ocupam apenas um fólio cada, ao invés de dois fólios, como em Mateus e Marcos. Seria o caso da perda de dois fólios? Ao que tudo indica, não. ${ }^{100}$

$\mathrm{Na}$ representação de Lucas, a parte inferior da imagem é semelhante às outras representações com os evangelistas. Ele está sentado sobre o trono, à direita, porta o livro sobre as mãos e a cortina também está presente. Na parte superior, contudo, no lugar do animal (touro), encontramos o personagem simbólico de Lucas, cabeça de touro, corpo humano e asas de anjo, que supostamente viria na imagem seguinte. Sobre ele, uma citação de Sedúlio "Iure sacerdotii Lucas tenet ore jubenci", como se utilizou nas imagens anteriores,

\footnotetext{
${ }^{98}$ YARZA LUACES, Joaquín. Las miniaturas. In: WILLIAMS, John et al. Beato de Fernando I y Sancha. Barcelona: M. Moleiro, 2006, p. 102

99 YARZA LUACES, Joaquín. Las miniaturas. In: WILLIAMS, John et al. Beato de Fernando I y Sancha. Barcelona: M. Moleiro, 2006, p. 104.

${ }^{100}$ A dúvida sobre a ausência de fólios pode ter sido reforçada porque em quatro outros Beati a cena de dos evangelistas ocupa 08 fólios, ou seja, é de cena dupla (evangelista em uma imagem e anjos com o personagem símbolo do evangelista em outra). São estes, o Beatus de Rylands (ff. 2v-6), Beatus de Las Huelgas (ff. 2v-6), Beatus de Saint-Sever (ff. 1v-5) e Beatus de Turin (ff. 4v-8). Além desses, o Beatus de Cardeña apresenta as imagens do anjo de Mateus (f. 9m), o evangelista Marcos (f. 9vm) e o evangelista João (f. 1g).
} 
referentes aos evangelistas. Mas abaixo, aparece uma nova inscrição, "Fuit sacerdos quidam n(o)mine Zaccarias", que é parte do quinto versículo do início do evangelho de Lucas. ${ }^{101}$ As inscrições levam a uma ideia de sintetização de duas imagens em uma, o que é reforçado pela representação de João em seguida. Nela, a parte inferior é ocupada por dois anjos com o evangelho de João e na superior temos o signo tetramórfico de João e duas inscrições. A primeira é de Sedúlio, "More volans aquile verbo petit astra Joahnnes" (a palavra de João sobe até os astros, como águia) e abaixo, o texto do evangelho "In principio erat verbum et $d(e u) s$ ert verbum". ${ }^{102}$ Também observamos que há uma correspondência entre a ornamentação das colunas e arco de Lucas e João, a qual aproxima o diálogo entre as duas imagens. Diante dessas observações é difícil supor a falta de um fólio que ocuparia a segunda cena de Lucas e outro da primeira cena de João. Todos os elementos compositivos mais básicos das duas cenas concentram-se em apenas um dos fólios. Além disso, o caderno que vai do f. 6 ao f. 11 está completo, formam-se bifólios entre os ff. 7-10 e entre os ff. 8-9 que ocupam o ciclo dos evangelistas; e a Regra de Gregory foi respeitada.

É difícil afirmar quais motivações poderiam levar a esse tipo de escolha, de "sintetização" de imagens. O que percebemos é uma maior dinâmica visual entre o grupo de seis imagens em comparação com outros Beati, nos quais a série ocupa oito fólios, de modo mais simétrico e com maiores repetições de localização espacial dos personagens, em comparação com o que vemos no Beatus de Facundus. A dúvida sobre a ausência de fólios no ciclo dos evangelistas pode ter sido reforçada pelo estudo comparativo com outras cópias. Ao todo, o ciclo aparece em oito Beati. Em quatro deles, a cena dos evangelistas ocupa oito fólios, ou seja, é de cena dupla (evangelista em uma imagem e anjos com personagemsímbolo do evangelista em outra). São estes: o Beatus de Rylands (ff. 2v-6), o Beatus de Las Huelgas (ff. 2v-6), o Beatus de Saint-Sever (ff. 1v-5) e o Beatus de Turin (ff. 4v-8). Além desses, o Beatus de Cardeña apresenta as imagens do anjo de Mateus (f.9m), o evangelista Marcos (f. 9vm) e o evangelista João (f. 1g), mas não podemos usá-lo como um comparativo viável, visto que este manuscrito é muito fragmentado e é provável que lhe faltem fólios. ${ }^{103}$

\footnotetext{
${ }^{101}$ YARZA LUACES, Joaquín. Las miniaturas. In: WILLIAMS, John et al. Beato de Fernando I y Sancha. Barcelona: M. Moleiro, 2006, p. 106.

${ }^{102}$ YARZA LUACES, Joaquín. Las miniaturas. In: WILLIAMS, John et al. Beato de Fernando I y Sancha. Barcelona: M. Moleiro, 2006, p. 108.

103 Do Beatus de Cardeña, 135 fólios são conservados no Museo Arqueologico Nacional, de Madri (cat. 1962/73/2), outros 15 fólios estão no Metropolitan Museum of Art, de Nova Iorque (coll. Vasselot), dois fólios estão na Coleção Francisco de Zabálburu y Basabe, Madrid, e mais um fólio pertence ao Museo de Arte de Gerona (Num. Inv. 47). Para referir-se ao local de conservação, acrescentam-se as letras m, n, z ou g,
} 
Devemos ainda observar as outras duas cópias, o Beatus de Girona (ff. 4v-7) e o Beatus de Morgan (ff. 1v-4). Em ambas há a representação de Lucas e João em cena dupla, mas quanto a Mateus e Marcos, cada um figura em um único fólio. Aparentemente, pode corresponder a um mesmo tipo de jogo utilizado no Beatus de Facundus, mas não se pode afirmar antes de um estudo da composição das imagens e das inscrições, o que não nos compete nesse momento. $^{104}$

Além dos dois primeiros cadernos, apenas o de número 33 e o último não são quaternos. O caderno 33 é o de construção mais complexa. Recorrer à Regra de Gregory, às comparações pontuais entre as imagens dos manuscritos e atentar-se para a composição dos cadernos são estratégias de visualização da obra. Nesse sentido, os esquemas podem ser muito úteis. Para ajudar na justificação da falta de fólios no caderno 33, Sánchez Mariana traça uma correspondência gráfica da construção dos bifólios da qual nos valemos para construir uma nova estrutura na Figura 8. O autor costura os números dos fólios com linhas que evidenciam o posicionamento de cada fólio dentro do caderno. Em nossa atualização, frisamos graficamente, por tracejado, a linha do fólio que também acreditamos existir e estar perdido, para distanciá-lo dos demais. E somamos, aos números e linhas, a descrição do conteúdo de cada fólio e a nossa aplicação da Regra de Gregory para melhor visualização. ${ }^{105}$

respectivamente, após o número do fólio. Isso quer dizer que as imagens do ciclo dos evangelistas encontram-se no Museu Arqueológico (m) e no Museu de Arte de Girona (g).

${ }^{104}$ Iniciamos este capítulo com uma fala sobre as dificuldades de acesso às fontes. E aqui reiteramos o problema. A análise dos ciclos dos evangelistas nas cópias de Girona e Morgan não pôde ser concluída não apenas pela extensão que exigiria da dissertação, mas porque as imagens disponíveis online são de péssima qualidade. No site da Morgan Library <http://ica.themorgan.org/manuscript/page/2/110807〉, é possível observar as imagens em seus aspectos mais rasos, mas não é possível ler as inscrições com clareza, nem usá-las como argumento para a composição da imagem. No f. 1v, é possível ler a inscrição presente no f. 7v do Beatus de Facundus, ou seja, apenas a citação de Sedúlio. Poderíamos pensar que não há uma condensação da imagem dos anjos na representação de Mateus, pela ausência da inscrição da cena seguinte, que lhe falta. Contudo, isso só poderia ser mais bem pensado se tivéssemos acesso à inscrição do fólio seguinte, da representação do anjo e o personagemsímbolo de Marcos, o que não acontece. Por isso é preciso sempre apontar para a importância do posicionamento de instituições como a Biblioteca Nacional da Espanha e da Biblioteca de Genebra, que disponibilizam o material de forma integral (texto e imagem) em excelente qualidade de visualização, com opção de download e impressão das imagens e que não reduzem o estudo do manuscrito à presença isolada da imagem e o desapreço pelo texto. A disponibilização pública do material é um meio importante para não deixar morrer uma imagem. Um objeto guardado, não visto, não pensado, é um objeto que deixa de viver. Sua existência é transformada em um nome em uma lista de 35 manuscritos, do qual muitos sabem que existem, mas que poucos podem ter acesso.

105 Os fólios que compõem o caderno 33 podem ser observados no site da Biblioteca Nacional da Espanha, disponível em: <http://bdh-rd.bne.es/viewer.vm?pid=d-1806167>. Acesso em: 25 nov. $2015 .$. 


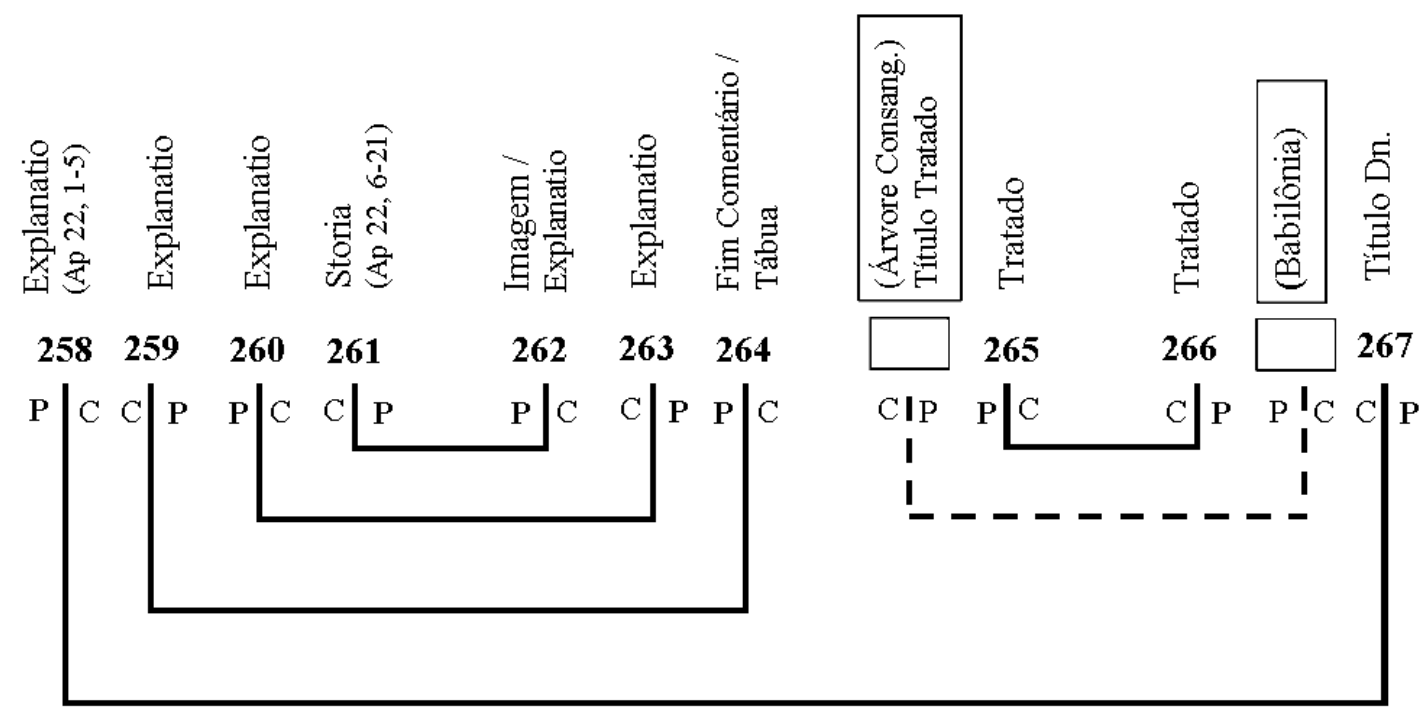

Figura 9. Formação do caderno 33 do Beatus de Facundus. Fonte: Elaborada pela autora ${ }^{106}$

O caderno 33 inclui o final dos comentários ao Apocalipse 22, versículos 1 a 5, que se iniciou no f. 254v, o trecho restante do Apocalipse 22, seguido de imagem e comentários. Também marca o fim do texto do Comentário ao Apocalipse e o início do Comentário ao livro de Daniel, intercalados pelo tratado De Adfinitatibus et Gradibus. Sánchez Mariana afirma que é provável que ao caderno falte um bifólio. Uma folha do bifólio estaria entre os ff. 264 e 265, provavelmente com a imagem da árvore de consanguinidade e o título do tratado, que falta a este Beatus. Na outra folha, entre os ff. 266 e 267, estaria a miniatura da Babilônia. ${ }^{107}$

John Williams afirma que, mesmo que se saiba que há uma possibilidade da Babilônia ter sido representada, como o é em outros Beati, ${ }^{108}$ não há uma evidência material para indicar que de fato o foi, e nisso concordamos com ele. Contudo, Williams não suspeita da falta desses fólios, visto que todos os bifólios estão intactos. São conjecturas que colocam as imagens de um manuscrito frente às outras cópias. Fora da série, as incertezas aumentam.

\footnotetext{
106 Montagem baseada no trabalho de Sánchez Mariana que traça as linhas de constituição dos cadernos. Lembramos que o caderno 33 corresponde ao caderno 31 nos trabalhos de Sánchez Mariana. SÁNCHEZ MARIANA, Manuel. La tradición de los Beatos y el Beato de Fernando I y Sancha. In: WILLIAMS, John et al. Beato de Fernando I y Sancha. Barcelona: M. Moleiro, 2006, p. 53.

107 SÁNCHEZ MARIANA, Manuel. La tradición de los Beatos y el Beato de Fernando I y Sancha. In: WILLIAMS, John et al. Beato de Fernando I y Sancha. Barcelona: M. Moleiro, 2006, p. 53.

108 Observamos a imagem da Babilônia figurada em sete Beati: Beatus de Girona (ff. 236v-237), Beatus de Rylands (f. 204), Beatus de Las Huelgas (f. 147), Beatus de Morgan (f. 238v), Beatus de Arroyo (f. 166), Beatus de Saint-Sever (f.2 17) e Beatus de Turin (ff. 187v-188).
} 
Acreditamos que é maior a probabilidade da perda de um fólio com o título do tratado $D e$ Adfinitatibus et Gradibus, que de uma miniatura que não aparece em todos os manuscritos, visto pelo tratamento gráfico dado aos outros títulos no Beatus de Facundus. ${ }^{109}$ E a Regra de Gregory parece estar ao nosso favor. Entre os ff. 264v e 265 há o encontro de face Carne com face Pelo, assim como no f. 266v temos face Pelo encontrando face Carne no f. 267. A presença do bifólio proposto por Sánchez Mariana solucionaria esses encontros divergentes à Regra. Mas ainda temos de estar atentos para que a Regra não se torne uma normativa imprescindível e suficiente para uma afirmação certeira.

Por fim, a última divergência está no caderno 35: a face Carne do f. $278 \mathrm{v}$ encontra a face Pelo do f. 279. Tanto para Sánchez Mariana quanto para Williams, este é um indício de falta de um fólio que apresentaria o final do texto da Visio tertia e a imagem do sonho de Nabucodonosor sobre a árvore (Dn 4). ${ }^{110}$

Na ordenação dos cadernos do Beatus de Facundus, temos a seguinte sequência:

\begin{tabular}{|l|l|}
\hline Fólios & Descrição \\
\hline $1-5 \mathrm{v}$ & Tábuas genealógicas \\
\hline 6 & Alfa \\
\hline $6 \mathrm{v}$ & Cordeiro e a Cruz \\
\hline 7 & Labirinto \\
\hline $7 \mathrm{v}-10$ & Ciclo dos Evangelistas \\
\hline $10 \mathrm{v}-17$ & Tábuas genealógicas \\
\hline $18-19 \mathrm{v}$ & Capitulatio (em 34 parágrafos) \\
\hline $19 \mathrm{v}-30$ & Storiae \\
\hline 30 & Prefácio \\
\hline $30-30 \mathrm{v}$ & Prólogo I e Prólogo II \\
\hline $30 \mathrm{v}-40$ & Interpretatio \\
\hline $40-263$ & Comentário ao Apocalipse \\
\hline $264 \mathrm{v}-266 \mathrm{v}$ & De adfinitatibus et gradibus \\
\hline $267-316$ & Comentário ao livro de Daniel \\
\hline 316 & Colofão \\
\hline $17 \mathrm{v}, 64 \mathrm{v}, 231$, & \\
$250,253,314$ & Fólios em branco \\
\hline
\end{tabular}

Quadro 2. Beatus de Facundus, sequência de imagens iniciais e conteúdo textual. Fonte: Sánchez Mariana, $20066^{111}$

\footnotetext{
${ }^{109}$ Sobre o tratamento gráfico dos títulos, ver adiante no capítulo 5, "A orquestração do Fim do Mundo".

110 SÁNCHEZ MARIANA, Manuel. La tradición de los Beatos y el Beato de Fernando I y Sancha. In: WILLIAMS, John et al. Beato de Fernando I y Sancha. Barcelona: M. Moleiro, 2006, p. 53; WILLIAMS, John. p.39; e WILLIAMS, John. The illustrated Beatus: a corpus of the illustrations of the Commentary on the Apocalypse. London: Harvey Miller, 1994-2003, v.3, p. 40.

111 Os dados do quadro provêm de SÁNCHEZ MARIANA, Manuel. La tradición de los Beatos y el Beato de Fernando I y Sancha. In: WILLIAMS, John et al. Beato de Fernando I y Sancha. Barcelona: M. Moleiro, 2006, p.54, exceto pela extensão que ocupa a Capitulatio. O autor encerra essa parte entre os ff. $18-29 \mathrm{v}$, mas a
} 
Na apresentação atual do manuscrito na Biblioteca Nacional da Espanha a contagem dos fólios parte das tábuas genealógicas provenientes, muito provavelmente, do Beatus de Valcavado. ${ }^{112}$ Optamos por utilizar a mesma contagem da Biblioteca, mas excluímos essas tábuas genealógicas do nosso estudo, de modo que o fólio inicial do manuscrito seja o f.6, com a imagem de Cristo dentro de um alfa monumental, a segurar a letra ômega. Esta imagem, assim como as outras oito posteriores (ff. 6-10), não são imagens do Apocalipse. As tábuas genealógicas do Beatus de Facundus ocupam os ff.10v-17, com uma imagem de Adão e Eva no f.10v, Noé no f.11v, Abraão e o sacrifício de Isaque no f.13, e no f.17 estão presentes a Virgem e o menino.

Entre as tábuas genealógicas e o prefácio aparecem duas estruturas que elencam o que virá a seguir. No Capitulatio o texto do Apocalipse é resumido em 34 seções; na storia, o texto mostra-se completo, retirado da storia do Comentário ao Apocalipse, aqueles fragmentos do texto sob os quais é construída a explicação (explanatio). O restante da estrutura é similar à estrutura geral dos Beati.

No último fólio do manuscrito encontramos o colofão, uma nota final com referências de identificação do manuscrito. O copista finaliza a cópia do Comentário ao livro de Daniel e confere a encomenda da obra aos reis de Leão e Castela, Fernando I e Sancha, bem como registra seu nome como copista, Facundus, e a data de realização, 1047 (1085 na Era Hispânica). ${ }^{113}$

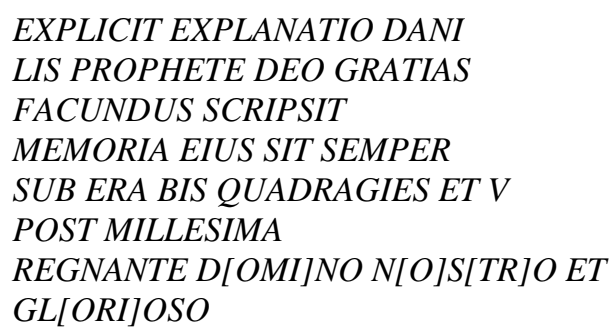

Capitulatio termina, na verdade, muito antes, no f. 19v. Acreditamos ser um erro de digitação, pois ele afirma que a Revelatio começa no f. 19v.

${ }^{112}$ Dissemos "provavelmente" pois nos fólios não há uma comprovação material da ligação. A equipe técnica da Biblioteca Nacional da Espanha, onde o manuscrito está conservado, afirma que as tábuas são, de fato, do Beatus de Valcavado (também conhecido como Beatus de Valladolid, referência a seu local de conservação). "Nos ff. 15, as Genealogias que pertencem ao Beatus de Valcavado, em Valladolid, Biblioteca de Santa Cruz, 433 (n. 341 ) influências moçárabes e norte africanas. [...] Em poder do marquês de Mondéjar desde o século XVII, foi requisitado junto com o resto de sua biblioteca por Felipe V na Guerra de Sucessão". Mas não há uma justificativa para tal afirmação. Disponível em: 〈http://bdh.bne.es/bnesearch/detalle/1806167>. Acesso em: 04 dez. 2015, tradução nossa.

113 WILLIAMS, John. The illustrated Beatus: a corpus of the illustrations of the Commentary on the Apocalypse. London: Harvey Miller, 1994-2003, v. 3, p. 34. Na Era Hispânica contam-se as datas a partir da conquista romana da região em 38 a. C. 
PRINCIPE D[O]M[IN]O FREDENANDO PROLIS
D[O]M[IN]I SANCTIONI ET CONIUNGE SUA
GLORIOSA D[O]M[IN]A SANCTIA REGINA
PROLIS ADEFONSI PRINCIPIS ANNO
REGNI SUI FUIT SCRIPTUM HOC LIBER. ${ }^{114}$

O nome do casal real também aparece na imagem do f. 7, mas deixaremos para falar melhor dela no capítulo 3.

Devido à deterioração, o f. 316 foi montado sobre um novo pergaminho e Dom Francisco Assencio y Mejorada copiou os dados do colofão, também como uma tentativa de cópia gráfica, com respeito à forma original da letra (Anexo F), e registrou, em seguida, o seguinte trecho, em 15 de setembro de 1879:

\begin{abstract}
Esta subscrição copiada pertence a este códice, ao final do pergaminho pregado à última tábua. Foi transladada aqui por estar já como que carcomida pelo tempo e pela importância de sua conservação por ser o Códice mais antigo que existe nesta Biblioteca Real. Copio ao vivo, como se vê. ${ }^{115}$
\end{abstract}

Além dessa, há outra anotação feita no manuscrito. No f.30 aparece uma inscrição de Ambrosio de Morales, de julho de 1572, quando este encontrou o manuscrito na biblioteca de Santo Isidoro (Anexo F). Morales escreveu na margem inferior sua impressão da obra e observou que continha o nome do copista Facundus, mas faltava o nome do compilador da obra, que viria a confirmar após encontrar o Beatus de Valcavado. ${ }^{116}$

Provavelmente estas duas interferências, somadas à presença das tábuas genealógicas de outro Beatus, sejam marcas de maior visibilidade do que falávamos como corpo de denúncia. ${ }^{117}$ São informações incrustadas no corpo do manuscrito que, mais do que falar por si, como dado de anotação ou de conservação de página, abrem este Beatus para uma maior gama de questionamentos. Elas nos dizem de um manuscrito que permaneceu "esquecido" e foi encontrado por Morales em um tempo muito específico de buscas.

Pensemos também no fato de o manuscrito ter sobrevivido e chegado até nós. Quantos outros livros não foram destruídos, queimados, esquecidos antes de se tornarem um objeto a

\footnotetext{
${ }^{114}$ WILLIAMS, John. The illustrated Beatus: a corpus of the illustrations of the Commentary on the Apocalypse. London: Harvey Miller, 1994-2003, v. 3, p. 34.

${ }^{115}$ Disponível em: 〈http://bdh-rd.bne.es/viewer.vm?pid=d-1806167>. Acesso em: 08 dez. 2015.

${ }^{116}$ MORALES, Ambrosio de. Los cinco libros postreros de la Crónica general de España. Córdoba: 1586, ff. 43-47.

${ }^{117}$ Ver p. 34.
} 
ser preservado. ${ }^{118}$ Por isso permanecemos com a afirmação de que este trabalho de pesquisa é um work in progress. O esvaziamento e fechamento de um objeto é uma ilusão que já não recai sobre o século XXI.

Fernando I, Sancha, Facundus, Etério, Ambrosio de Morales e Francisco Assencio y Mejorada, além dos comentaristas citados por Beato de Liébana - são todos os nomes que encontramos no Beatus de Facundus. Observamos que não há em todo o manuscrito, nem no colofão, uma referência ao miniaturista, ou aos miniaturistas. Yarza Luaces sustenta a ideia de que as ilustrações foram trabalhadas por dois miniaturistas diferentes, e que nenhum deles era Facundus. ${ }^{119}$ Seu argumento parte de três observações. A primeira baseia-se nos muitos erros contidos nas legendas que acompanham as imagens, como a transcrição de hic por ic (f. 141v) e outros erros que o fazem duvidar se o miniaturista sabia escrever ou ler, ao menos perfeitamente. Sua segunda observação parte da relação entre a feitura das imagens próximas ao texto, como no f. 300.

[...] é evidente que o miniaturista se deparou com uma superfície pequena para contar uma história [...] Em outros códices da família que poderiam ter servido de modelo, [a imagem] ocupa um maior espaço. Por conseguinte, chega a invadir a caixa da letra, quando se trata de um artista muito ponderado e que sabe bem compor. Se fosse o caso de ser o mesmo copista, teria previsto isso ao escrever previamente o texto. $^{120}$

Contudo, as duas primeiras observações de Yarza Luaces não são indícios suficientes para crer que Facundus não possa ter iluminado o manuscrito. O latim medieval apresenta muitas variações, seria preciso um estudo mais detalhado de todas as inscrições do texto e das inscrições nas outras cópias. Os erros nas legendas, mencionados por Yarza Luaces, poderiam ser uma reprodução de erros já presentes no modelo, e não um erro originado nesta cópia, por responsabilidade do miniaturista. Não é possível saber se, caso o miniaturista fosse Facundus, ele corrigiria os erros vindos do modelo de que se serve para a cópia. Quanto à ocupação da imagem no fólio, não é casual ou falha do miniaturista que as mãos de Daniel toquem seu próprio nome escrito no texto. Não se trata de uma falta de previsão do espaço que a imagem

\footnotetext{
${ }^{118}$ POLASTRON, Lucien X. Livres en feu. Histoire de la destruction sans fin des bibliothèques. París: Denoël, 2004.

${ }^{119}$ YARZA LUACES, Joaquín. La ilustración del Beato de Fernando I y Sancha. In: WILLIAMS, John et al. Beato de Fernando I y Sancha. Barcelona: M. Moleiro, 2006, p. 81.

${ }^{120}$ YARZA LUACES, Joaquín. La ilustración del Beato de Fernando I y Sancha. In: WILLIAMS, John et al. Beato de Fernando I y Sancha. Barcelona: M. Moleiro, 2006, p. 79, tradução nossa.
} 
ocuparia, mas da possibilidade de dinâmica entre texto e imagem. Daniel reforça sua presença como imagem, ao tocar em seu nome escrito no texto.. Essa dinâmica não pode ser reduzida a um simples indício de que copista e miniaturista são pessoas diferentes. Novamente é preciso recorrer a comparações com outras imagens do manuscrito e com outras cópias.

Já a terceira observação do autor parece mais plausível, mas ainda questionável. Yarza Luaces observa a execução plástica de cada miniaturista, que são visivelmente diferenciadas e supõem a existência de dois miniaturistas. O primeiro ocupa os ff. $6-17$, executa a imagem com maior número de detalhes, desenha os personagens com traços firmes na silhueta e nos pontos essenciais de cada miniatura. $\mathrm{O}$ segundo, que ocupa o restante do códice, retoma o sistema representativo do primeiro, mas o simplifica. Um exemplo claro de diferenciação está nos riscos do rosto dos personagens e nos cabelos: o primeiro miniaturista desenha inicialmente as linhas do rosto com o preto e depois emprega o vermelho, e os cabelos adornam as cabeças de duas ou três maneiras diferentes, todas de modo meticuloso. Já o segundo miniaturista utiliza linhas puramente negras no rosto e os cabelos são simples, apenas com um traço (Figura 10). Para Yarza Luaces, "Em ambos existe uma ponderação do conjunto, uma capacidade de compor de modo que tudo esteja ajustado, na busca, se necessário, de linhas e eixos de simetria". ${ }^{121}$

${ }^{121}$ YARZA LUACES, Joaquín. La ilustración del Beato de Fernando I y Sancha. In: WILLIAMS, John et al. Beato de Fernando I y Sancha. Barcelona: M. Moleiro, 2006, p. 82. 

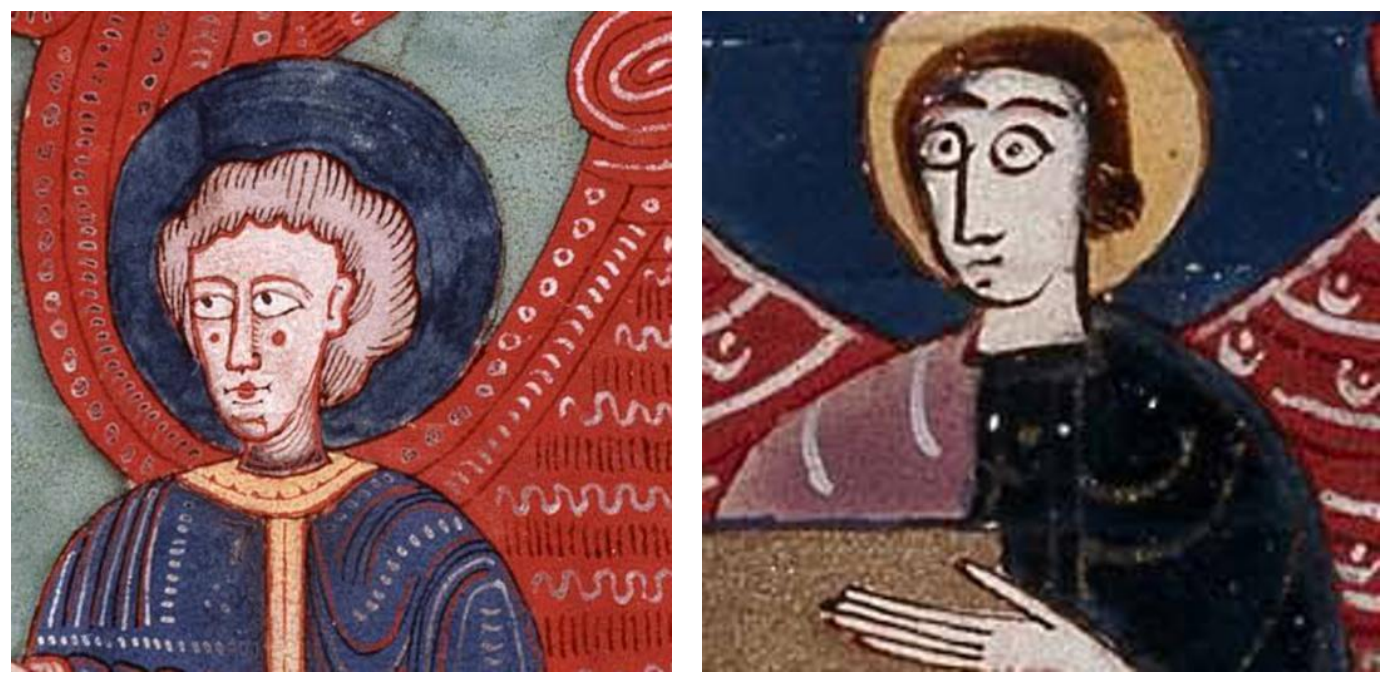

Figura 10. Beatus de Facundus, detalhes dos ff. 10 e 116v.

Fonte: www.bne.es (recorte da autora)

Na Figura 10, colocamos duas imagens lado a lado de modo aleatório, sem pensá-las como parte de uma série. Apenas pegamos dois rostos, sem nomes, sem contextos, sem razão. O que queremos aqui evidenciar é o risco de se pensar as imagens como ilustrações de um argumento. A imagem não deve reforçar um posicionamento teórico como se a construção dela existisse em prol desse discurso. De fato, observamos a diferença de tratamento visual dos cabelos e dos traços faciais nos dois personagens, mas a descrição mantém-se no campo das representações puramente formais. ${ }^{122}$ Somemos mais um dado formal às afirmações de Yarza Luaces:

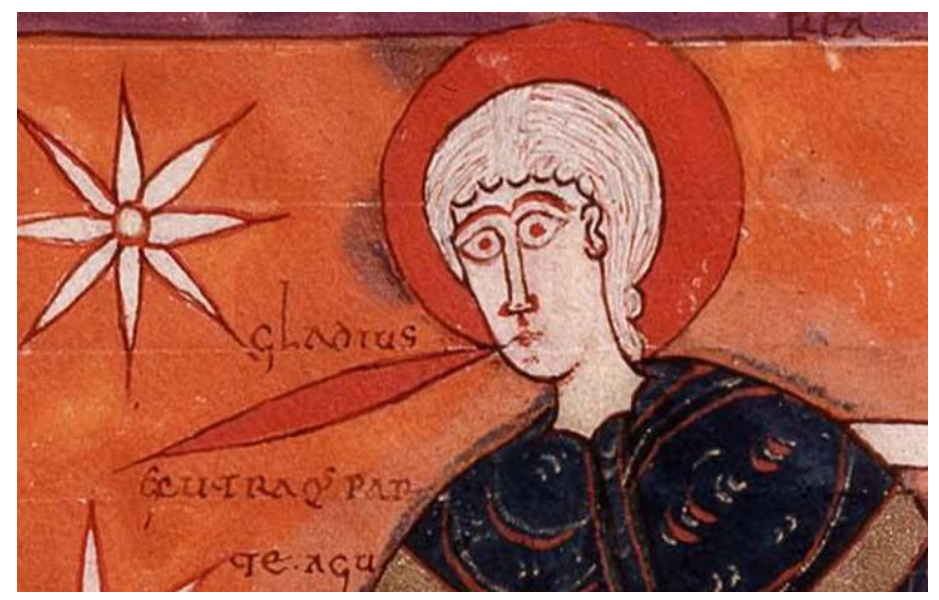

Figura 11. Beatus de Facundus.

Fonte: www.bne.es (recorte da autora)

\footnotetext{
${ }^{122}$ As imagens utilizadas pelo autor para embasar suas afirmativas são do f. 10 (a mesma que da Figura 12 acima), outro anjo do f. 9 e Cristo no f. 6 como "retratos do primeiro miniaturista" e o Cristo no f. $43 \mathrm{v}$ como "retrato do segundo miniaturista". YARZA LUACES, Joaquín. La ilustración del Beato de Fernando I y Sancha. In: WILLIAMS, John et al. Beato de Fernando I y Sancha. Barcelona: M. Moleiro, 2006, p. 81-82, tradução nossa.
} 
O modo de tratamento formal das linhas que compõem o rosto do personagem o qualifica como um trabalho do primeiro miniaturista, semelhante ao personagem do primeiro quadrante da figura 10, correto? Se seguirmos as delimitações colocadas por Yarza Luaces, entramos em contradição, porque este personagem encontra-se no f. 46, que deveria ser, segundo o autor, trabalho do segundo miniaturista. Omitimos parte da legenda da imagem propositalmente, para manipulá-la como uma ilustração de um argumento a que se quer provar.

Falar sobre autoria, origens distantes e sobre originalidade implica maior cautela. Percebemos o peso de uma historiografia que necessita de conclusões, de confirmações, e que não lida de modo positivo com as aberturas que um objeto possa fornecer quando pensado de modo mais aberto, contextual, parte de uma série. Mesmo quando falamos de características mais formais, porque obviamente elas existem e não podem ser negadas, é preciso não as fechar sobre si mesmas. Um dado formal não deve ser pensando apenas sob o viés formal. A forma não está isolada na imagem, como se ela também não fizesse parte do objeto. A imagem é uma máquina e suas engrenagens não são apenas as linhas. É preciso dar nomes, dar poder à imagem, para que ela funcione e não se paralise segundo a vontade do pesquisador. Na figura 11, o personagem é o Senhor, Cristo e Deus, manifestado como um ancião de cabelos brancos em visão para João. Será que, por ser ou não um mesmo miniaturista a trabalhar, a escolha visual de figuração do personagem de Deus seria a mesma que do personagem de um ancião dentre tantos outros figurados na imagem do f. $116 \mathrm{v}$ (segundo quadrante da figura 10)? Ou a figuração de Deus estaria mais próxima da escolha do primeiro quadrante da figura 10 para mostrar o anjo que segura o evangelho de João? É preciso sair da imagem isolada para podermos pensar sobre tais argumentações. ${ }^{123}$

Questionamos as pequenas certezas de Yarza Luaces, mas ainda deixamos, por ora, a questão um tanto em aberto. Ela será clarificada ao longo do trabalho. Apenas acrescentamos, sobre a discussão de Yarza Luaces, seu posicionamento quanto à não citação dos nomes dos

\footnotetext{
${ }^{123}$ Quando a necessidade estranhamente humana de se agarrar a uma certeza alcança o historiador e ele chega, como chegamos, a pensar, ingenuamente, que a imagem do f. 46 poderia ainda ser trabalho do primeiro miniaturista, mas não as posteriores, é preciso retornar e pensar em uma série maior. De fato, quando observamos todas as imagens do Beatus de Facundus com olhos estatísticos, com pequenas exceções, a maior parte dos rostos dos personagens posteriores ao f. 17 segue um "padrão" semelhante ao descrito por Yarza Luaces, do uso de linhas pretas e cabelos como massas densas. Mas uma imagem medieval não funciona por estatísticas. No f. $112 \mathrm{v}$ encontramos Deus entronizado com o rosto composto por linhas pretas e vermelhas e o cabelo semelhante a um trabalho do suposto primeiro miniaturista. A questão maior que trazemos aqui não é saber quem ou quantos foram os miniaturistas, mas o quão pertinente pode ser esse dado para o funcionamento da imagem.
} 
miniaturistas no colofão. Segundo ele, Facundus teria citado apenas seu nome porque, até a data de 1047, os miniaturistas ainda não teriam começado seu trabalho. ${ }^{124}$ Mas isso, certamente, é ainda mais difícil de utilizarmos como argumento para uma construção histórica.

Concluímos esta seção com a ideia de que falar de formalismo e materialidade não implica que o objeto deva ser reduzido a tais elementos. Um objeto apenas material jamais seria percebido, tocado, pensado, ele nem mesmo existiria se tudo, inclusive aquele que olha e pensa, fosse também matéria inerte. Matéria é indício, é denúncia para pensamentos e reflexões por aqueles que a estudam e não um corpo estanque e fechado sobre sua própria materialidade, desconectada de seu ambiente. A matéria é uma partícula de uma complexa engrenagem que move a imagem.

${ }^{124}$ YARZA LUACES, Joaquín. La ilustración del Beato de Fernando I y Sancha. In: WILLIAMS, John et al. Beato de Fernando I y Sancha. Barcelona: M. Moleiro, 2006, p. 79. 


\section{COMO ABRAÇAR UMA MÁQUINA: O ORNAMENTO COMO ENGRENAGEM DA IMAGEM}

Começamos a construir a nossa noção de imagem medieval como máquina pelas engrenagens que se movem através do funcionamento das peças materiais de seu corpo. Cada partícula que compõe um Beatus é parte motora dessa máquina chamada imagem-objeto. Uma máquina, como um aparelho, exige uma programação e um programador que a faça funcionar (exercer determinada ou determinadas funções). O programador é uma figura ambivalente composta de um desenvolvedor de imagens materiais (miniaturista, no nosso caso) que cria através do verdadeiro criador da imagem medieval, que é Deus. ${ }^{125}$ As mãos desse programador humano são guiadas pelo ideal teológico do Criador, do Verbo que fala por imagens. ${ }^{126}$ A programação, por outro lado, parece depender de uma maior gama de sujeitos sobre a imagem.

Uma imagem materializada ainda possui suas funções em estado potencial. As funções da imagem mantêm-se de modo virtual até que sejam atualizadas na execução do programa. Essa necessidade de executar para que a imagem exista e funcione a faz "depender" de uma ação externa à sua criação. A imagem encerrada em sua forma e desgarrada de suas funções não passaria de um "gato de Schrödinger". ${ }^{127}$ Existir como imagem é funcionar como imagem.

\footnotetext{
${ }^{125}$ A nossa aproximação quanto ao programador da imagem medieval segue uma visão própria à antropologia e teologia cristãs, que se afasta de concepções modernas de arte, artista e genialidade daquele que cria uma imagem material. Falamos de Deus que é o Criador de imagens, que fez Cristo à sua imagem e semelhança e que através das mãos humanas criou novas imagens.

${ }^{126}$ Imagem tanto textual quanto imagética propriamente dita. A linguagem divina construída pelo desvio, através de metáforas, analogias, metonímias, contribui para a abertura a várias interpretações da palavra, e o desenvolvimento de comentários a livros, como os Comentários ao Apocalipse. Sobre as práticas bíblicas, ver BOYNTON, Susan; REILlY, Diane J. (ed.). The Practice of the Bible in the Middle Ages: Production, Reception, and Performance in Western Christianity. New York: Columbia University Press, 2011.

${ }^{127}$ A experiência mental conhecida como "gato de Schrödinger" foi proposta pelo austríaco Erwin Schrödinger, em 1935, como metáfora aproximativa do princípio de indeterminação quântica. Nessa experiência, imaginamos um gato encerrado em uma caixa totalmente isolada de interferências externas. Dentro da caixa haveria ainda um frasco de veneno e um martelo ligado por um "disparador" a um contador Geiger com uma pequena porção de matéria radioativa. Caso um dos átomos da substância decaia o contador acionará o martelo, quebrará o frasco e o gato morrerá. A probabilidade de que isso não ocorra é de igual valor. Enquanto a caixa não for aberta, a única resposta válida para determinar a condição do gato é que ele se encontra em estado "morto-vivo", isto é, seu estado é potencial.
} 
Uma lâmpada é uma máquina programada para fornecer luz, mas se não for ligada a uma fonte de energia e acionada por um sujeito, ela não cumpre sua função original. ${ }^{128} \mathrm{~A}$ imagem medieval, como a lâmpada, é um objeto material potencialmente funcional. Ela é programada por essa composição que lida, por um lado, com a materialidade composicional e, por outro, com a engrenagem da imagem em função virtual, que pode ser acionada. Mas, não falamos de uma função que possa ser analisada de modo isolado, precisa e necessária, que se engendraria independente do funcionamento geral dessa máquina e sua existência dentro de um contexto. Talvez fosse melhor falarmos de "modos de funcionamento", pois, como sugere Baschet, "[...] há sempre mais funcionamento que função; a obra, por seu sentido e seus efeitos, ultrapassa sempre sua função". ${ }^{129}$

A ideia de imagem medieval como máquina e aparelho, como propomos, está longe de uma definição simples e unívoca. Sua complexidade é própria da noção de imago e da dependência de seu acionamento. O sujeito do século XI, que aciona as engrenagens do Beatus de Facundus, certamente o faz em contiguidade com as possibilidades de seu tempo, assim como nós, do século XXI, acionamos a mesma máquina segundo potencialidades que mais dizem de nosso tempo que do tempo da imagem original. ${ }^{130}$ Não somos meros apertadores de botões dessa máquina, ${ }^{131}$ mas construtores da atualização do dispositivo. Isso

\footnotetext{
${ }^{128}$ Dizemos função original, por compreendermos que a função depende desse conjunto guiado pela ação. Uma lâmpada pode muito bem servir como um vaso de pequenas plantas, se arrancarmos sua estrutura elétrica e a reduzirmos a um vaso de vidro (no caso de lâmpada incandescente). Mas ela ainda seria uma lâmpada. O mesmo questionamento pode ser levado para as imagens medievais e toda produção imagética que se afasta de seu contexto de origem. A imagem medieval exposta em museus ainda funciona e vive da mesma forma?

${ }^{129}$ BASCHET, Jérôme. Introdução à imagem-objeto. In: ; SCHMITT, Jean-Claude (orgs.). L'image. Fonctions et usages des images dans l'Occident médiéval. Paris: Le Léopard d'Or, 1996, p. 7-26, p.16 (tradução: Maria Cristina C. L. Pereira).

${ }^{130}$ Didi-Huberman se baseia nas ideias de Deleuze para falar de imagens "[...] que nem sequer estão 'no presente', como em geral se crê de forma espontânea. E é justamente por que as imagens não estão 'no presente' que são capazes de tornar visíveis as relações de tempo mais complexas que incumbem a memória na história. Gilles Deleuze o diria mais tarde, à sua maneira: 'Parece-me evidente que a imagem não está no presente [...] A própria imagem é um conjunto de relações de tempo de que o presente só deriva, apenas como um múltiplo comum, ou como o mínimo divisor. As relações de tempo nunca se veem na percepção ordinária, mas sim na imagem, enquanto criadora. Torna sensíveis, visíveis, as relações de tempo irredutíveis ao presente"'. DIDIHUBERMAN, Georges. Quando as imagens tocam o real. Tradução de Patrícia Carmello e Vera Casa Nova. Pós: Belo Horizonte, v. 2, n. 4, p. 204 - 219, nov. 2012.

${ }^{131}$ É importante indicarmos que conceitos como programação, aparelho e funcionamento são fortes na filosofia de Vilém Flüsser, da qual certamente bebemos. No entanto, não nos parece cabível, pelas fronteiras da discussão aqui proposta, trabalharmos com suas conceituações de maneira mais profunda. A proposta de estudo das imagens deixada por Flüsser direciona-se especificamente para as "imagens técnicas", construídas a partir do advento da fotografia. Entrevemos ganho em fazer uso parcialmente dessas ferramentas teóricas, mas reconhecemos os limites decorrentes da distinção de natureza entre as "imagens técnicas" e as imagens medievais. Sobre as imagens técnicas, ver, sobretudo, FLÜSSER, Vilém. O Universo das Imagens Técnicas: Elogio da Superficialidade. São Paulo: Anna-blume, 2008.
} 
implica que a máquina não possa ser vista como um elemento puramente artificial (e material), em contraposição à natureza humana. Criador, criação, detentor e usuário são todos sujeitos no diálogo multifacetado da imagem medieval como máquina. ${ }^{132}$

Como parte de uma construção histórica, como poderíamos nos aproximar dos modos de funcionamento da imagem medieval sem que fôssemos retidos completamente pelas aderências históricas sofridas pelo programa, como aquelas próprias da institucionalização da imagem museológica? Seria absurdo e pretensioso dizer que é possível deixarmos nosso tempo. Mas ter conhecimento das implicações de estar no mundo, dá-nos a possibilidade de atualizar a imagem medieval segundo uma lógica de que ela também nos alcança e torna-se parte do nosso lugar no mundo. Pensemos no que aconteceria com uma pequena placa de encadernação em marfim do século X se fosse encontrada por um funcionário do Google. Ela poderia ser ignorada ou ser deslocada, por exemplo, para a mesa de trabalho desse funcionário, que a usaria como peso de papel ou "objeto da sorte", a depender do evento do encontro. De todo modo, ela não seria uma imagem medieval, mesmo se ele soubesse de sua datação, pois as engrenagens da máquina foram acionadas por outros meios. ${ }^{133}$ As aderências de tempos, do seu caminho até sua descoberta, suplantaram sua programação. E isso não quer dizer que ela não funcione, apenas que ela não funciona como imagem medieval.

Para que nos aproximemos dos modos de funcionamento da imagem medieval é preciso que ela nos toque como tal, que possamos abraçar não apenas a máquina e suas engrenagens, mas também sua programação. O abraço é um modo de envolver e ser envolvido. Um movimento mútuo que envolve, mas não funde nem mistura as partes da ação. O abraço mantém a particularidade dos envolvidos ao mesmo tempo em que permite que eles possam se ver além dos olhos.

Abraçar uma imagem não é fundir o tempo da imagem ao nosso tempo, mas é reafirmar que cada um ocupa seu lugar e, mesmo assim, há um tempo dispensado a essa experiência do contato. Uma experiência que não se encontra na enumeração de dados, na soma das partes fragmentadas, nem no descrever formal do que se olha. $\mathrm{O}$ abraçar a imagem

\footnotetext{
${ }^{132}$ Dizemos usuário por acreditarmos que a palavra talvez fizesse melhor jus a sua relação de uso e consumo da imagem medieval. Espectador é um termo que guarda uma especificidade que não encontramos necessariamente nessas imagens, pois o olhar do sujeito medieval que olha, não é um olhar de observador apenas, mas um olhar que consome a imagem.

${ }^{133}$ Não reduzamos as possibilidades desse funcionário do Google, mesmo que hipotético, ter um interesse por produção medieval e que ele possa, sim, trabalhar de freelancer como curador de mostras de "arte" medieval. Cada trabalho e estudo dedicado à placa de encadernação a aproximaria de uma imagem medieval. Acreditamos que o trabalho de pesquisa seja um meio de mostrar a imagem dentro de seu próprio funcionamento.
} 
diz mais do processo, da experiência, da funcionalidade de ambos os corpos que da visão simplificada dos mesmos.

Quando compreendemos que a imagem medieval pode ser acessada por essa movimentação mútua, a máquina exige que seja posta em ação através de suas próprias ferramentas. Como outros dispositivos, a imagem medieval não necessita de apenas uma ferramenta para que suas engrenagens trabalhem. Aqui nos dedicamos a uma em especial, o ornamento, que durante tanto tempo foi dispensado desse funcionamento.

No campo de estudos do ornamento, observamos que não há um consenso geral sobre o que o define, apesar de ter assumido, dentro da História da Arte, limites que o colocam como um objeto de fácil identificação, como arabescos e temas vegetais. Mas, esses limites de identificação se modificam a cada abordagem. Podemos assumir parâmetros para criar diferenciações, mas, de modo algum, amputar a amplitude de alcance do termo. Essa amplitude pode ser percebida na própria etimologia da palavra ornamento. No latim medieval, ornamentum pode assumir variada significação que, basicamente (quer dizer, não apenas), divide-se em dois espectros de ação: "aquilo que orna, aquilo que veste, que decora" e "aquilo que permite funcionar, que é útil". ${ }^{134}$ No primeiro conjunto estão também palavras como orno, ornatus e ornare: designam particularmente toda espécie de beleza, são recursos para ornar, decorar, embelezar, honrar, distinguir e exaltar. Pode se tratar de um objeto precioso, um enfeite ou adorno (roupa ou joia), ou outros materiais que em suas aplicações envolvem um sentido estético. Mas podem também ter sentido figurado, isto é, ornamento como brilho, prestígio, glória, virtude (qualidades morais e espirituais que são o adorno da alma, por exemplo). ${ }^{135}$ Nesse conjunto de variações dos sentidos e usos da palavra ornamentum, identificamos com maior claridade o entendimento atual e ordinário do ornamento como objeto decorativo. Intimamente, se não estritamente, relacionado a seu caráter de beleza, é comum suprimir outros aspectos atuantes no embelezamento e também ligados a origem da palavra, como a honra e o prestígio, para restar uma ideia limitada de complemento de beleza.

É dessa origem estética voltada à beleza decorativa que nasceram as teorias mais tradicionais do ornamento, localizadas principalmente entre as décadas de 1850 e 1950.

\footnotetext{
134 ARNALDI, Francesco et al. Ornamentum In: ___. Novum Glossarium Mediae Latinitatis. Copenhague: Munksgaard, fascículo Ordior-Oz, 1983-2011. Disponível em: <http://scriptores.pl/ngml/view?docId=Ordior-Oz/Ordior-Oz.xml>. Acesso em: 15 jun. 2014.

135 ARNALDI, Francesco et al. Ornamentum In:___. Novum Glossarium Mediae Latinitatis. Copenhague: Munksgaard, fascículo Ordior-Oz, 1983-2011. Disponível em: <http://scriptores.pl/ngml/view?docId=Ordior-Oz/Ordior-Oz.xml>. Acesso em: 15 jun. 2014.
} 
Dizemos tradicionais mais para frisar a tradição que para cristalizá-las em um sentido pejorativo de superação. ${ }^{136}$ Para as teorias tradicionais, o ornamento localizava-se em uma questão formal, como um elemento belo aposto sobre uma superfície, da qual, se retirado, não traria prejuízos, senão estético e formal. Esse caráter de exterioridade deve muito às restrições modernistas ao ornamento, que foram muitas vezes lidas e citadas fora de seus contextos. Não apenas o ornamento foi reduzido ao aspecto decorativo, mas os próprios debates deste período, de 1850-1950, sofreram restrições à sua profundidade teórica. Debates esses que envolviam historiadores da arte, artesãos, críticos, teóricos, designers e arquitetos, mas que muitas vezes eram reduzidos às conhecidas fórmulas antiornamentais, como "o ornamento é crime", de Adolf Loos, e "é preciso parar de ornamentar", de Louis Sullivan. ${ }^{137}$ Tais afirmativas esvaziaram-se de seus contextos de origem e sintetizaram toda a produção teórica daquele momento a uma negação do uso do ornamento. Da teoria do ornamento, produzida no período em questão, foi retirado o diálogo com a produção industrial, em que o ornamento já não tinha lugar, em comparação às utilidades do objeto. ${ }^{138}$ Também foram ignorados os impactos do surgimento de exposições internacionais, as quais apresentavam produções até então periféricas à história da arte ocidental, como os artefatos Maori, ${ }^{139}$ e o desenvolvimento da Art Nouveau. Esses eram eventos que se relacionavam diretamente com o papel do ornamento nas produções daquele período. Em todo caso, não havia uma restrição ao ornamento por se tratar de um simples complemento de beleza formal, mas por ter se afastado da experiência da arte daquele momento, por ter se recusado a participar da criação das formas e misturar-se genuinamente aos materiais. O diálogo do ornamento com a matéria

\footnotetext{
${ }^{136}$ Não ultrapassamos teorias, a História das imagens não é evolutiva, nem uma corrida. Todo o material considerado tradicional o é por ser base para outros pensamentos.

${ }^{137}$ PAIM, Gilberto. A beleza sob suspeita: o ornamento em Ruskin, Lloyd Wright, Loos, Le Corbusier e outros. Rio de Janeiro: J. Zahar, 2000, p. 09. O livro de Gilberto Paim traz diferentes significações atribuídas ao ornamento em autores da modernidade e abre a discussão da ornamentação para um âmbito da vivência, correlacionada ao contexto em que é empregado, como na sua relação com a produção industrial.

${ }^{138}$ Adolf Loos fala de uma diferença de sensibilidade do homem moderno em comparação a outras épocas: "Nossa sensibilidade é mais delicada que a dos homens Renascentistas [...] Mais delicada ainda do que aquela da era rococó, quando se tomava a sopa sobre um fundo de cebolas azuis que lhe dava uma desagradável cor cinza esverdeada. Nós preferimos comer sobre um fundo branco." PAIM, Gilberto. A beleza sob suspeita: o ornamento em Ruskin, Lloyd Wright, Loos, Le Corbusier e outros. Rio de Janeiro: J. Zahar, 2000, p.62.

${ }^{139}$ Segundo os adeptos da teoria técnico-materalista, como Gottfried Semper, os primeiros padrões ornamentais teriam surgido espontaneamente de técnicas e materiais utilizados na tecelagem. O primeiro padrão teria, portanto, sido observado, e não inventado, no padrão da tecelagem que depois passaria a ser reproduzido em outros materiais. Riegl, pautado no impulso criativo para a formação de novos padrões, i.é, um novo padrão derivado de outro padrão, critica a teoria técnico-materialista a partir da existência de padrões ornamentais em culturas que não conheciam a técnica de tecelagem, como os Maori. PEDRONI, Fabiana. Por uma definição do ornamento. In: IX Encontro de História da Arte - UNICAMP, 2013, Campinas. Anais do IX Encontro de História da Arte - Circulação e trânsito de imagens e ideias na História da Arte. Campinas, SP: Unicamp, 2013. p. 80-85.
} 
passava a ser baseado em um disfarce da precariedade, uma ostentação de um luxo inexistente. Temos uma produção e teorização do ornamento distinta e específica nesse final de século XIX e início do XX, tão específica que não pode ser pensada fora de seus parâmetros. O ornamento não é um elemento concreto e inflexível, ele está diante do tempo, é afetado pelo espaço que ocupa. A folha de acanto de um capitel coríntio não será a mesma folha de acanto de um vaso de porcelana comprado em uma loja de departamento. $\mathrm{O}$ ornamento pode ter uma história, como propõe Aloïs Riegl, mas essa história nunca será linear. ${ }^{140}$ Pode-se localizar o ornamento em um tempo, ao fazer datações e procedências, mas não se deve esvaziá-lo de suas possibilidades de atuação nem mesmo de sua operacionalização teórica em momentos distintos. Afinal, teria o ornamento de acanto as mesmas formas e funções, na produção grega, romana e mesmo contemporânea?

A intensa, senão pesada, herança modernista na teoria do ornamento teve como consequência certa supervalorização da forma. Reduzido a uma forma aplicada de modo impensado, ou compulsivo, a um objeto, o ornamento seria um elemento puramente decorativo (que chegou mesmo a ser odiado). ${ }^{141}$

Contudo, o ornamento, em sua origem etimológica, na palavra ornamentum, abarca algo mais que a forma. Diferente das ideias modernistas, o ornamento, na concepção medieval, possui utilidades, seria "aquilo que permite funcionar, que é útil". A reprodução impensada das restrições ao ornamento parece ter cegado grande parte dos estudiosos sobre essas contribuições. Cegueira tão seletiva que se deixou passar trabalhos como de Lloyd Wright, que afirmava a necessidade de se pensar o ornamento na raiz do projeto, e de que ele nascesse em harmonia com o projeto arquitetônico inicial. $\mathrm{O}$ ornamento não seria aposto de modo impensado a um prédio, residência, mas pensado na totalidade do projeto arquitetônico e artístico. $^{142}$

\footnotetext{
${ }^{140}$ Questão de estilo é vista como conjunto de características formais que distinguem e qualificam um objeto segundo o modo e a época em que foi produzido. RIEGL, Aloïs. Problemas de estilo: fundamentos para una historia de la ornamentación. Versión castellana de Frederico Miguel Saller. Barcelona: Gustavo Gili, 1980.

141 Henri Van de Velde, em seu livro "Fórmulas da beleza arquitetônica moderna", faz uma interessante descrição de uma sopeira de Meissen, ao tratar de seu método para identificar ornamentos teatrais ou supérfluos. Ele a descreve como um grande monumento, com uma vasta cúpula, figuras (golfinhos, cisnes, guirlandas de flores e frutas, sereias, etc.), uma encenação apoteótica, para no fim acrescentar: "[...] Anfitrite e Amor viajam nas costas de um golfinho vermelho e gigante que sopra pelo nariz dois jatos de uma massa verde tão espessa que não pode haver dúvida de que essa sopeira está até a borda de sopa de repolho!". PAIM, Gilberto. A beleza sob suspeita: o ornamento em Ruskin, Lloyd Wright, Loos, Le Corbusier e outros. Rio de Janeiro: J. Zahar, 20000, p.82.

142 ALOFSIN, Anthony. Frank Lloyd Wright, the Lost Years, 1910-1922: A Study of Influence. Chicago: University of Chicago Press, 1994. Foi na busca de um projeto ao mesmo tempo funcional e expressivo que
} 
O ornamentum é da ordem do equipamento, daquilo que fornece o necessário para o funcionamento adequado de um mobiliário, moinho, navio ou mesmo de tropas militares (os soldados que se vestem de armas). ${ }^{143}$ Também é aquilo que concerne à liturgia, isso inclui o mobiliário litúrgico, roupas, cortinas, relicários e outros objetos que formam os bens de uma igreja ou monastério, chamados de ornamenta ecclesiae. ${ }^{144}$ Esse "tesouro" também possuía um equivalente laico - ornamenta regia -, objetos que marcavam o status social do detentor e mostravam-se como "insígnia de poder (real ou imperial)". ${ }^{145}$

Apesar de aqui nos guiarmos por essa separação dos significados do termo ornamento, presente no Dicionário Internacional de Latim Medieval (800-1200), o Novum Glossarium Mediae Latinitatis, ${ }^{146}$ pode-se observar que um conjunto de sentidos dialoga com o outro. $\mathrm{O}$ equipamento não é só útil, ele também é belo; a beleza do ornamento não é só forma, é também utilidade. Afastamo-nos da concepção comum de ornamento, como complemento de beleza, para aproximarmo-nos da ideia medieval de uma beleza que é formada por uma porção externa (decor) associada a uma dimensão honorífica (decus), para juntas aderirem a um suporte de modo conveniente (decet). ${ }^{147}$ Ou seja, o ato de embelezar confere valor e honra ao objeto que orna, de modo que o caráter estético do ornamento seja adequado, decente, ao valor suposto do objeto. Por exemplo, uma coroa determina o status e poder de um rei, e para

Louis Sullivan contribuiu para a teoria do ornamento. A partir da observação das transformações sofridas pelas formas naturais, das formas que surgem de outras formas, Sullivan lançou sua máxima, que depois seria tão repetida: "A forma segue a função". Frase que parece, hoje, significar simplesmente que a boa forma adequa-se à função objetivamente. Esquece-se que, na verdade, Sullivan falava sobre "A interrelação entre função e forma não tem começo nem fim. Ela é incrivelmente pequena e incomensuravelmente vasta, inescrutavelmente móvel, infinitamente serena, intimamente complexa - e simples, até." SULLIVAN, Louis Form and function. In:

Kindergarten Chats and Other Writings. Nova York: Wittenborn Art Books, 1968, p. 43. Ou seja, a mutabilidade constante da forma e da função faz com que não haja uma forma definida para determinada função.

143 ARNALDI, Francesco et al. Ornamentum In:___. Novum Glossarium Mediae Latinitatis. Copenhague: Munksgaard, fascículo Ordior-Oz, 1983-2011. Disponível em: <http://scriptores.pl/ngml/view?docId=Ordior-Oz/Ordior-Oz.xml>. Acesso em: 15 jun. 2014.

144 Antes da época carolíngia, havia uma distinção entre os objetos que serviam ao culto, chamados de ministeria, e aqueles que ornavam as celebrações, os ornamenta, como as pinturas, esculturas, relicários, mobiliário litúrgico. Posteriormente, essa distinção tornou-se mais tênue, sendo nomeados como ornamenta ecclesiae, em que o uso no plural sublinha o valor que se adere a sua acumulação.

${ }^{145}$ ARNALDI, Francesco et al. Ornamentum In: ___. Novum Glossarium Mediae Latinitatis. Copenhague: Munksgaard, fascículo Ordior-Oz, 1983-2011. Disponível em: <http://scriptores.pl/ngml/view?docId=Ordior-Oz/Ordior-Oz.xml>. Acesso em: 15 jun. 2014. Também em BONNE, Jean-Claude. Les ornements de l'histoire (à propos de l'ivoire carolingien de Saint Remi). Annales Histoire, Sciences Sociales, 51 ${ }^{\mathrm{e}}$ année, n. 1, p. 37-70, jan/fév. 1996, p. 45. Disponível em: <www.persee.fr/doc/ahess_0395-2649_1996_num_51_1_410833>. Acesso em: 15 out. 2015.

${ }^{146}$ Disponível em: <http://scriptores.pl/ngml/view?docId=Ordior-Oz/Ordior-Oz.xml>. Acesso em: 10 jan. 2016.

${ }^{147}$ BONNE, Jean-Claude. Les ornements de l'histoire (à propos de l'ivoire carolingien de Saint Remi). Annales Histoire, Sciences Sociales, $51^{\mathrm{e}}$ année 51, n. 1, p. 37-70, jan/fév. 1996, p. 45-46. Disponível em: <www.persee.fr/doc/ahess 0395-2649_1996_num_51_1_410833>. Acesso em: 15 out. 2015. 
que ela o legitime como tal, a coroa deve conter ornamentos decentes a tal propósito. Agregase ouro, pedras preciosas e formas decorativas que se adéquam a essa legitimação de poder e status. Encontramos essas relações entre decor e decus em uma fórmula de Isidoro de Sevilha, retomada por Jean-Claude Bonne, na distinção e união da alma ao corpo: "Decus ad animum refertur, decor ad corporis speciem". ${ }^{148}$

Se adentrarmos na origem etimológica da palavra ornamentum, perceberemos que essa tênue separação também ocorre em kosmos, palavra grega que tem no ornatus sua tradução latina. ${ }^{149}$ Kosmos significa um arranjo adequado que une as ideias de ordem, beleza e mundo uma bela ordenação do mundo. ${ }^{150}$ Essa noção é estritamente ligada à retórica, sob a ideia de decoro, ou conveniência.

\begin{abstract}
O ornamento e sua disposição, observados em uma perspectiva retórica, mostram-se como fundamentais para garantir o decoro e a realização da bela ordem, que faz com que aquele ambiente cumpra com eficácia sua função - ou funções, seja de polo agregador e centralizador da vida social, seja como centro de intercâmbios e estruturações das relações de poder, seja como o paraíso terrestre ou o lugar mais próximo do sagrado na Terra. ${ }^{151}$
\end{abstract}

A ordenação de kosmos também se relaciona à origem da palavra latina ordinare, que por haplologia, supressão de uma ou duas sílabas, declina para ornare ${ }^{152}$ que junto de ornamentum e outras palavras da mesma família de orno possuem os sentidos de ordenação e

${ }^{148}$ BONNE, Jean-Claude. De l'ornemental dans l'art médiéval (VIIè - XIIè siècle): Le modele insulaire. In: SCHMITT, Jean-Claude; BASCHET, Jérôme (orgs). L'image: Fonctions et usages des images dans l'Occident médiéval. Paris: Le Léopard d'Or, 1996, p. 218.

${ }^{149}$ PUHVEL, Jaan. The Origins of Greek Kosmos and Latin Mundus. The American Jounral of Philology, vol. 97, n. 2, p.154-167, Summer, 1976.

${ }^{150}$ Como a palavra Kosmos é fonte geracional da palavra ornamentum, ambas possuem significações semelhantes. Sobre a análise etimológica de kosmos como forma de organização militar, ver HAEBLER, Claus. Kosmos: Eine etymologisch-wortgeschichtliche Untersuchung. Archiv für Begriffsgeschichte, n.11, p. 101118, 1967.

${ }^{151}$ SANTOS, Aline Benvegnú dos. A ornamentalidade dos capitéis do claustro de Sant Benet de Bages: as funções do decor na arte românica. 2014. 243 p. Dissertação (Mestrado em História Social) - Programa de PósGraduação em História Social, Universidade de São Paulo, São Paulo, 2014, p. 146. Ver também o trabalho de Selene Candian dos Santos sobre as técnicas retóricas e suas implicações nos textos de Saint-Denis, século XII. SANTOS, Selene Candian. Arte retórica em Ordinatio, De consecratione e De administratione de Suger de Saint-Denis. 2014. 2 volumes. (Mestrado em História Social) - Programa de Pós-Graduação em História Social, Universidade de São Paulo, São Paulo, 2014.

${ }^{152}$ GROS, Pierre. La notion d'ornamentum de Vitruve à Alberti. Perspective, n. 1, p. 130-136, 2010. Disponível em: <http://perspective.revues.org/1226>. Acesso em: 23 nov. 2015. Gros traça uma noção da ideia de ornamento e suas declinações através dos usos da palavra ornamentum e suas variações etimológicas nos escritos de Vitrúvio e Alberti. O autor mostra como o ornamento possui um importante papel estrutural nas construções arquitetônicas a partir do confrontamento entre as concepções vitruvianas e de Alberti, este que dá ao ornamento um caráter maior de exterioridade. 
beleza. A ideia de beleza em kosmos forma o que hoje conhecemos por cosmética (kosmétikê). ${ }^{153}$ Uma das primeiras referências a esse aporte estético está em uma passagem da Ilíada, em que Hera se veste, orna seu corpo com toda sua elegância (kosmon), para seduzir Zeus. ${ }^{154}$

Sabemos que essas duas atribuições dadas ao ornamento são dialógicas, mas a distinção é proveitosa para frisar a existência da porção funcional (a que faz funcionar), deixada de lado em detrimento da porção formal (da forma que embeleza), e que só muito recentemente recebeu atenção no campo teórico do ornamento. O ornamento é uma bela ferramenta de engrenagem que faz funcionar a máquina que é a imagem. Oleg Grabar, em "Do ornamento e suas definições", ${ }^{155}$ afirma que, dentre as muitas acepções do termo, as partes formal e funcional recebem diferentes graus de atenção teórica. A primeira seria uma definição mais clara e precisa, mas de pouco interesse intelectual. Nela o ornamento é definido como uma forma desprovida de sentidos (iconográfico ou outro qualquer), que pode ser copiada em diferentes suportes, independente de um embasamento cultural para a escolha - a forma ditaria a repetição. O pouco interesse intelectual a que ele se refere está preso aos estudos de datações e procedências estilísticas que evidenciam um aspecto de rigor, de trabalho preciso, porém limitados às especificidades formais dos ornamentos e nas técnicas de produção. Menos clara, mas mais interessante, segundo o autor, a segunda acepção deixaria as especificidades formais e técnicas em segundo plano para preocupar-se com o efeito produzido pelo ornamento e, sobretudo, o prazer oferecido pelas composições, pelas cores, proporções, expressões e outras categorias analíticas das obras de arte. ${ }^{156}$ Esses efeitos, segundo ele, não deveriam se subordinar às censuras predominantes no meio intelectual desde o último quarto do século XX, tempo em que o prazer deveria ser deixado apenas aos "críticos e amadores", como diz Grabar. ${ }^{157}$ Ele frisa os sentimentos e as atitudes causadas pelo ornamento, que afetam a compreensão da obra pelo sujeito.

\footnotetext{
153 PRÉVOST, Bertrand. Cosmique cosmétique. Pour une cosmologie de la parure. Images Re-vues, n. 10, p. 02-32, 2012. Disponível em: <http://imagesrevues.revues.org/2181>. Acesso em: 10 nov. 2014. Neste artigo, Prévost trabalha as relações entre cosmo e cosmética no desenvolvimento da ornamentação corporal.

${ }^{154}$ PUHVEL, Jaan. The Origins of Greek Kosmos and Latin Mundus. The American Jounral of Philology, vol. 97, n. 2, p.154-167, Summer, 1976, p. 157.

155 GRABAR, Oleg. De l'ornement et de ses définitions. Perspective, n. 1, 2010, p. 5-7. Disponível em: <http://perspective.revues.org/1195>. Acesso em: 10 jan. 2016.

156 GRABAR, Oleg. De l'ornement et de ses définitions. Perspective, n. 1, 2010, p. 6. Disponível em: <http://perspective.revues.org/1195>. Acesso em: 10 jan. 2016.

${ }^{157}$ A concepção de Oleg Grabar sobre a função de um crítico é minimamente curiosa. Talvez seja apenas uma força de expressão, mas o fato é que crítico é justamente o contrário de amador, então, como que o prazer é
} 
É em meditação sobre o ornamento nesse sentido que nós podemos eventualmente compreender os sentimentos e as atitudes que afetam nossa compreensão das artes de maneira geral e que nós escondemos habilmente dentro de pesquisas estilística ou iconográfica. A este nível, o ornamento não é mais uma coisa, mas uma emoção, uma paixão, uma ideia, o que afeta tudo que é criado pelos artistas e artesãos. É uma propriedade da obra de arte que transforma aquele que a olha. ${ }^{158}$

É preciso cautela nas reflexões que se seguem. A citação não nos aparece como um argumento para provar o abraço à imagem no seu sentido "comocional", como parece sugerir os efeitos do ornamento no sujeito pensado por Grabar. Tendo em mente que o texto é breve e sintético, como o deve ser um material de abertura de uma edição de revista, no caso, a Perspective, sabemos que essa citação está longe de resumir as contribuições de Grabar sobre o estudo do ornamento. Fazemos a ressalva, principalmente, quanto à generalização de ações por parte do ornamento (pensado por Grabar nesse texto) geradas no sujeito, independente da obra que olhe ("das artes de maneira geral"), pois nem toda arte pode ser ou ter caráter de ornamento. A imagem medieval não funciona e nem existe segundo os mesmos sentidos que a imagem como obra de arte, assim como não há um conjunto delimitado de reações à arte. Salvo essas distinções, podemos frisar a contribuição de Grabar ao considerar o ornamento não como uma coisa, "mas uma emoção, uma paixão, uma ideia", o que confere ao ornamento um caráter de ato, próximo aquele conferido às imagens por Sartre, na diferença de que, em Grabar, o ornamento pode ser inerente como propriedade, que gera comoção, o que não acontece no conceito de "ato", por Sartre. ${ }^{159}$ A imagem acontece dentro do próprio ato que lhe dá origem. Para Sartre, a imagem é certo tipo de consciência, consciência de alguma coisa. Por esse motivo, não haveria uma diferença de natureza qualitativa entre o objeto da percepção e o objeto da imaginação. ${ }^{160}$ Ao entremear essas duas noções, de um ornamento como propriedade de uma imagem (matéria) e de uma imagem que se dá no acontecimento (ação), temos uma engrenagem potencialmente funcional dentro da materialidade da imagem

relegado a dois lados opostos ao mesmo tempo? Não seria, pensamos, um sentimento de "amadores", um sentimento que cega, mas aquele que faz ver profundamente, de modo transparente, em que cada elemento que compõe a obra possui o papel de fazê-la funcionar.

158 GRABAR, Oleg. De l'ornement et de ses définitions. Perspective, n. 1, 2010, p. 6. Disponível em: <http://perspective.revues.org/1195>. Acesso em: 10 jan. 2016.

${ }^{159}$ SARTRE, Jean-Paul. A imaginação. Porto Alegre, RS: L\&PM, 2011.

${ }^{160}$ A distinção entre a consciência perceptiva e a consciência imaginante encontra-se na produção de diferentes atos: "Os objetos produzidos pela percepção são sínteses de aparições e os objetos-imagens não são sínteses, são presenças na sua totalidade imediata, são evidências". ARRUDA, Francimar Duarte. A questão do imaginário: a contribuição de Sartre. Em Aberto, Brasília, ano 14, n.61, p.78-85, jan./mar. 1994. Quer dizer, a relação da consciência com o objeto-imagem dá-se sem intermediários, de maneira imediata que pressupõe o encontro anterior com o objeto perceptivo (Reconhecemos o que conhecemos). 
medieval. Esta não é unicamente o resultado de uma técnica, o corpo de uma máquina, mas é também uma imagem em trabalho, a engrenagem que a faz funcionar junto de suas ferramentas.

Dizer que a imagem é "ato" é colocá-la como parte de um processo que garante a experiência de "resultados" não prontos, que podem ser modificados a qualquer instante. Experiência esta que é guiada pelo diálogo de duas atribuições básicas do ornamento, pertencentes ao universo do ornamentum e do kosmos. Tornamos mais evidente que a beleza do ornamento não é externa, mas funcional e própria do ato que a compõe. O trabalho do ornamento dependerá do trabalho da imagem e vice-versa. Ou seja, é possível ao ornamento assumir outras funções que não apenas a decorativa, assim como um dos modos de trabalho da imagem é pela ação do ornamento. Note-se que, aqui, neste diálogo, a decoração torna-se uma das possíveis funções da extensa programação de uma máquina que é a imagem medieval, e não a única função.

A diferenciação entre um ornamento que é apenas decorativo, em um sentido estrito, e um ornamento potencialmente funcional é base também para o trabalho de Jean-Claude Bonne. Para sublinhar a existência da função (e utilidade) no ornamento, Bonne assume significações diferenciadas para dois conjuntos de palavras: ornamento e ornamentação destinam-se ao aspecto mais formal do ornamento, e ornamental e ornamentalidade, dedicamse à funcionalidade, sem excluir a forma de seu entendimento. Como a forma pode contribuir para o trabalho da imagem? Para respondermos a essa questão precisamos antes aprofundar o entendimento dos termos ornamental e ornamentalidade, propostos Bonne, em contraposição a ornamento e ornamentação. Depois seguiremos para o trabalho da forma ornamental como decoração, símbolo e memória. 


\subsection{Forma, função e o conceito de ornamental e ornamentalidade}

Até o momento em que nos encontramos neste processo de estudo do ornamento, evidenciamos o conceito como herdeiro de sua origem etimológica, nos sentidos que envolvem as ideias de ornamentum e cosmos, como parte de uma imagem que é máquina, como uma engrenagem que a faz funcionar no acontecimento. Muito devemos para essa conceituação ao esforço de Jean-Claude Bonne de dar ao ornamento seu caráter funcional, que o faz através da cunhagem de novos termos, o ornamental e a ornamentalidade. Apesar de Bonne explicar os motivos para a adoção desses termos em contraposição ao ornamento, reforçar essa separação poderia implicar na negação de sua origem etimológica. Bonne separa e operacionaliza os dois termos inaugurados por ele, mas mais que frisar uma separação e operacionalização, nós queremos restituir o caráter funcional ao ornamento dentro de seu próprio vocábulo. ${ }^{161}$

As definições traçadas por Bonne são importantes didaticamente para compreendermos como o ornamento pode mostrar-se útil e funcional na imagem. Contudo, a partir do momento em que definimos os termos, pensamos ser necessário abri-los novamente. Ou seja, não nos prenderemos dentro da forma do próprio nome.

De início, digamos que o ornamento pode ser pensado como um motivo, uma unidade essencialmente formal, como afirma Bonne, a exemplo da folha de acanto, de entrelaços, de outros motivos vegetais ou geométricos. ${ }^{162}$ A união destes motivos por repetições, variações ou combinações diversas forma composições denominadas de ornamentação. Para Bonne, a ornamentação pode ser aplicada a um objeto preexistente, se inscrever em zonas determinadas

\footnotetext{
${ }^{161}$ Jean-Claude Bonne não faz essa negação, ele, de fato, também utiliza a ideia de ornamentum para embasar seus argumentos, principalmente em BONNE, Jean-Claude. Les ornements de l'histoire (à propos de l'ivoire carolingien de Saint Remi). Annales Histoire, Sciences Sociales, 51e année, n. 1, p. 37-70, jan/fév. 1996. Disponível em: <www.persee.fr/doc/ahess_0395-2649_1996_num_51_1_410833>. Acesso em: 15 out. 2015. Mas acreditamos que essa separação, já distante do contexto teórico dos primeiros estudos de Bonne da década de 1990, não é mais tão necessária. Bonne marca essa separação para frisar a utilidade do ornamento, para que ele deixe a margem de "gênero menor" quando comparado as grandes narrativas na História da Arte. Insistir na separação como consequência da teoria de Bonne poderia simplificar a profundidade de seus esforços, assim como, com o passar do tempo, as teorias modernistas do ornamento foram má interpretadas, fora de seu contexto original. Este estudo tem um contexto próprio, localizado mais próximo de uma amplitude do alcance da palavra que na definição e distinção de sentidos.

162 BONNE, Jean-Claude. De l'ornement à l'ornementalité: La mosaïque, de San Clement de Rome. Actes du Colloque International: Le rôle de l'ornement dans la peinture murale du Moyen Âge. Saint-Lizier, 1-4 juin 1995. Poitiers: Université de Poitiers, 1997, p.103.
} 
de objetos, de imagens, ou de monumentos (molduras, partituras, superfícies de preenchimento, ou outras superfícies). ${ }^{163}$ Apesar dessa conceituação do ornamento parecer isolá-lo como um objeto, segundo Bonne, "Um ornamento não é uma entidade positiva que podemos isolar para considerá-la nela mesma". ${ }^{164}$ Talvez tenha sido esse o grande ponto de cisão entre as correntes formais e funcionais do ornamento. $\mathrm{O}$ ornamento pensado fechado em sua forma pode ser encontrado em catálogos de repertórios e padrões de ornamento, muito comuns a partir do século XVI, e que até hoje são reeditados e reproduzidos como material de consulta a artistas, designers, pesquisadores, outros profissionais e mesmo "curiosos". Na figura 12, que vemos a seguir, o ornamento é destituído de seu lugar e colocado ao lado de outros padrões que não funcionam senão dentro da sua própria forma, como parte de uma grande amostragem.
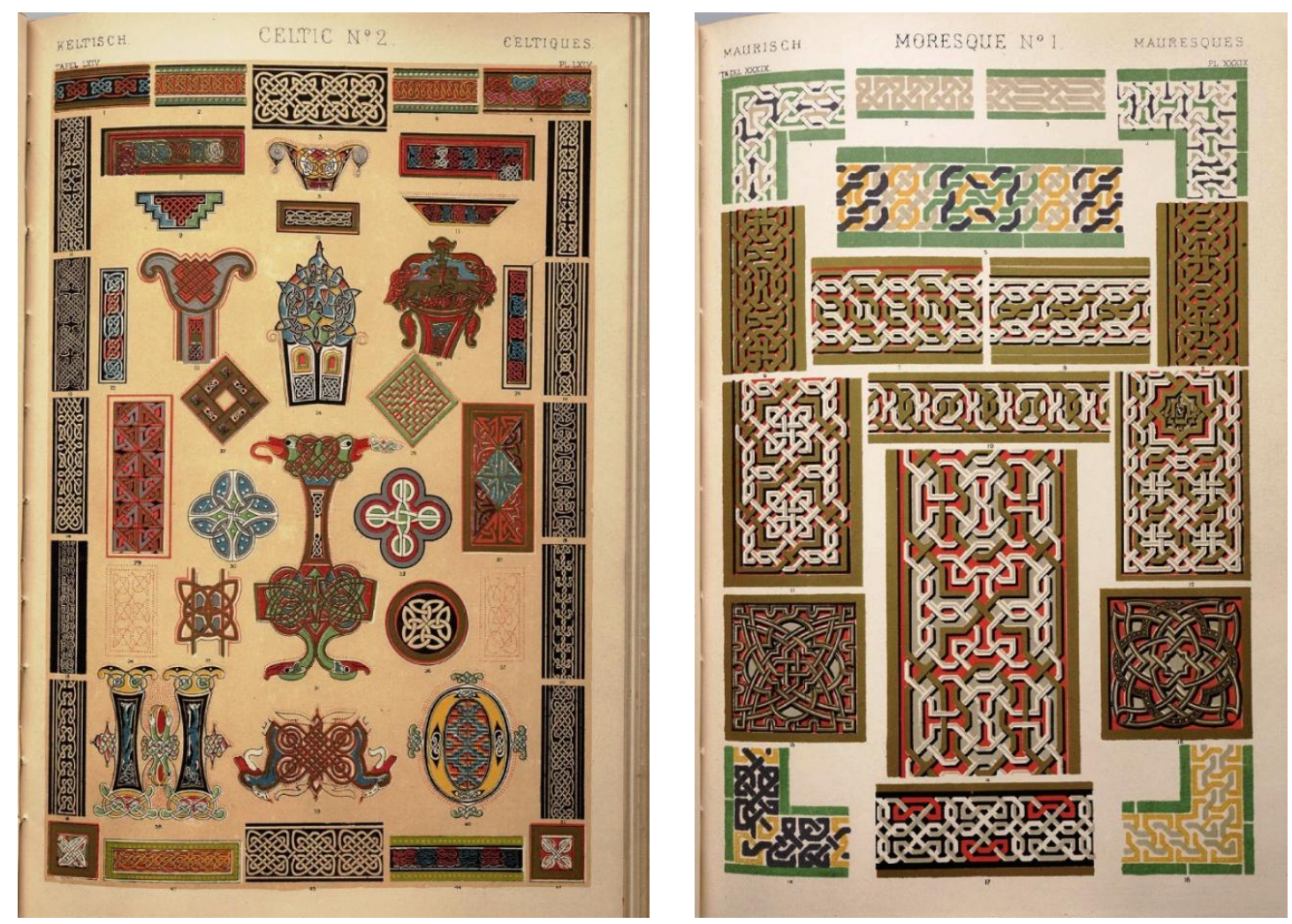

Figura 12. Entrelaços celta e mourisco.

Fonte: Owen Jones, $1856 .^{165}$

${ }^{163}$ BONNE, Jean-Claude. De l'ornemental dans l'art médiéval (VIIè - XIIè siècle): Le modele insulaire. In: SCHMITT, Jean-Claude; BASCHET, Jérôme (orgs). L'image: Fonctions et usages des images dans l'Occident médiéval. Paris: Le Léopard d'Or, 1996, p. 213.

${ }^{164}$ BONNE, Jean-Claude. Repenser l'ornement, repenser l'art médiéval. In: Le rôle de l'ornement dans la peinture murale du Moyen Âge. Actes du Colloque International, Saint-Lizier, 1-4 juin 1995. Poitiers: Université de Poitiers, 1997, p. 218.

165 JONES, Owen. The Grammar of Ornament. Londres: Cary Collection, Rochester Institute of Technology, 1856, p. LXIV e XXXIX. 
Um dos catálogos mais importantes e conhecidos é a "Gramática do Ornamento", do arquiteto Owen Jones, de 1856. Ele não apenas coletou e descreveu formalmente vários exemplos de ornamento usados desde a Grécia e Egito Antigo à China Imperial, como também formalizou 37 princípios básicos para a criação desses padrões. Esforços como o de Jones são importantes para estudos que pretendem reconhecer, datar e identificar a transmissão dos ornamentos entre diferentes culturas. Apesar de catálogos como este contribuírem com o uso descontextualizado e indiscriminado dos repertórios de ornamento, Jones faz uma advertência aos copistas no prefácio de sua obra e mostra sua preocupação contra esse uso.

\begin{abstract}
Ao justapor as muitas formas de beleza que cada estilo ornamental apresenta, espero contribuir para interromper essa tendência infeliz do nosso tempo que consiste em copiar, enquanto é moda, formas criadas em outras épocas, na ignorância das circunstâncias particulares que tornaram belos os ornamentos que eram expressivos e apropriados - os mesmo ornamentos que fracassaram inteiramente quando transplantados. ${ }^{166}$
\end{abstract}

Segundo Bonne, é devido ao ornamento não ser da ordem dos sentidos, a priori, que pode ter permitido que os padrões fossem copiados e transmitidos entre culturas diferentes. ${ }^{167}$ A exclusão, ou suspensão, da ideia direta de signo pode ser percebida de modo mais claro em ornamentos mais abstratos que figurativos, como elementos geométricos. Observemos, por exemplo, uma seleção de padrões de ornamentos celtas e mouriscos (Figura 12), compilados por Owen Jones, para que possamos operacionalizar os termos cunhados por Bonne, o ornamental e a ornamentalidade. Estes ornamentos utilizam linhas curvilíneas entrelaçadas, linhas que se misturam e passam umas por dentro das outras até criarem uma forma específica, um entrelaço. Esse tipo de ornamento é encontrado também em outras culturas, como nas produções carolíngias.

No Beatus de Facundus encontramos os entrelaços a ornar as bordas das imagens e alguns elementos muito específicos. No caso do f. 7, o entrelaço aparece na borda e ocupa praticamente todo o espaço da imagem, como vemos nas Figuras 13 e 14.

\footnotetext{
166 JONES, Owen. The Grammar of Ornament. Londres: Cary Collection, Rochester Institute of Technology, 1856, tradução nossa.

${ }^{167}$ BONNE, Jean-Claude. "Relève" de l'ornementation celte païnne dans un évangile insulaire du VIIe siècle (Les Evangiles de Durrow)". Actes de Ideologie e Pratiche del Reimpiego nell'Alto Medioevo. Espoleto, Itália: Centro Italiano di Studi sull'Alto Medioevo, 1999, v.2. p. 1014.
} 


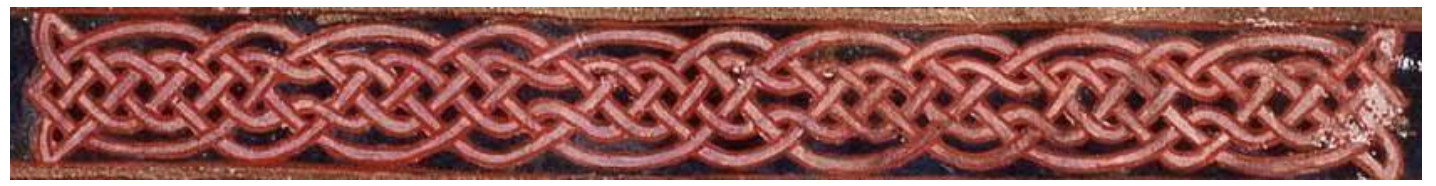

Figura 13. Ornamento de entrelaço.

Fonte: www.bne.es (Beatus de Facundus, f. 7, recorte da autora)

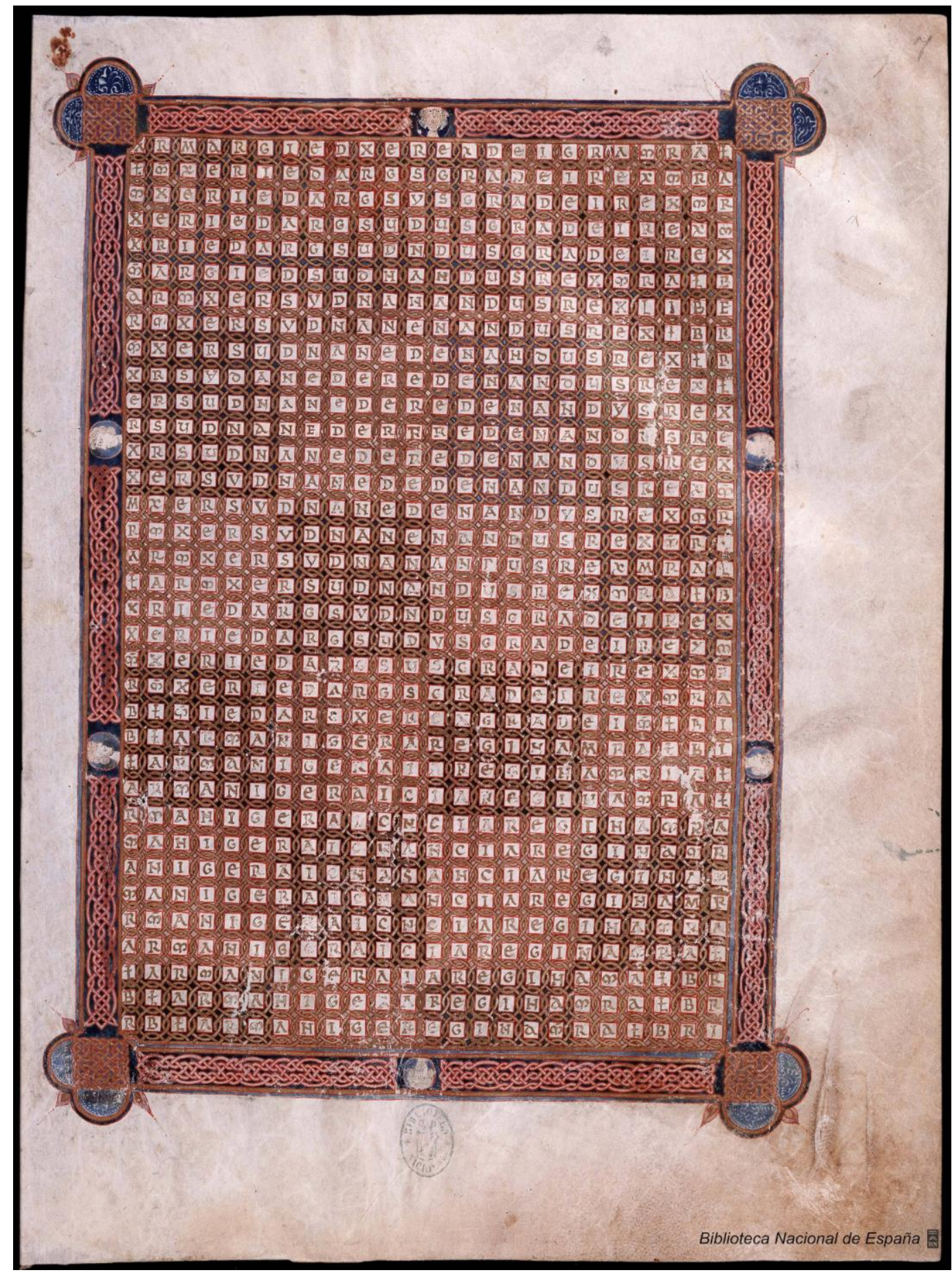

Figura 14. Beatus de Facundus, f. 7, labirinto.

Fonte: www.bne.es ${ }^{168}$

168 Optamos por mostrar a imagem em fólio inteiro e exibir os limites do fólio para evidenciar seu corpo e espacialidade dentro da página. Algumas imagens que não forem mostradas em fólio inteiro no corpo do texto 
Se fosse possível isolarmos o ornamento em sua forma, poderíamos dizer que o entrelaço é um motivo de ornamentação repetido e variado na imagem do f. 7. Contudo, esse isolamento não é possível. Quando pensamos o ornamento na imagem, ele passa a fazer parte dela, não de modo subordinativo, ${ }^{169}$ mas em diálogo e mesmo em gerência de seu funcionamento. Para pensarmos o ornamento é preciso pensar também a imagem dentro de suas possibilidades contextuais.

No f. 7 temos um labirinto, um sistema, que segundo Yarza Luaces, vem do mundo antigo e se tornou relativamente comum em códices alto medievais espanhóis, utilizados para fazer menção a dados da encomenda, desde o nome do escriba ou miniaturista a pessoa que o encomendou. ${ }^{170}$ Dentre os Beati, além do Beatus de Facundus, outros quatro possuem essa configuração de tapete de letras: Beatus de Silos (1109, f. 6 e f. 276), Beatus de Morgan (952, f. 1), Beatus de Saint-Sever (1075, f. 1) e Beatus de Valcavado (970, f. 2).

No Beatus de Facundus, o sistema é formado por letras, aparentemente aleatórias, distribuídas em espaços delimitados pela ornamentação, mais ou menos profusa. O espaço de cada letra é circundado por alguma forma geométrica, neste caso, em pequenos quadrados. Ao todo, são 840 quadrados distribuídos em 35 linhas e 24 colunas. Em determinada sequência de quadrados-letras encontramos a dedicatória do manuscrito como encomenda do casal real, Fernando I e Sancha. Mais especificamente, no quadrante 12x12 (linha/coluna), temos a letra F, da qual parte, nas quatro direções dos lados do quadrado, o nome de Fernando I, e no quadrante 29x12, a letra S, de Sancha, de modo similar. Na junção dessas letras pode-se ler: "Fredenandus rex Dei gra[tia] m[emo]r[i] a l[ibri]" e "Sancia regina m[emo]r[i] a libri". 171

Os nomes dos comitentes, e sua memória, são envolvidos por essas linhas em ouro, entrelaçadas em seu corpo e distribuídas nos limites dos quadrados-letra. Dito isso, os entrelaços afastam-se de uma concepção externa à imagem, por enquanto, no sentido formal. Dentro dessa estruturação, são eles que sustentam as letras no tapete. Retiremos toda a ornamentação e as letras "caem" do fólio. A forma do ornamento afeta a estrutura da imagem.

podem ser conferidas no site da Biblioteca Nacional da Espanha. Disponível em: <http://bdhrd.bne.es/viewer.vm?pid=d-1806167>. Acesso em: 25 nov. 2015..

169 BONNE, Jean-Claude. De l'ornemental dans l'art médiéval (VIIè - XIIè siècle): Le modele insulaire. In: SCHMITT, Jean-Claude; BASCHET, Jérôme (orgs). L'image: Fonctions et usages des images dans l'Occident médiéval. Paris: Le Léopard d'Or, 1996, p. 208.

${ }^{170}$ YARZA LUACES, Joaquín. Las miniaturas. In: WILLIAMS, John et al. Beato de Fernando I y Sancha. Barcelona: M. Moleiro, 2006, p. 96, tradução nossa, grifo nosso.

171 SÁNCHEZ MARIANA, Manuel. La tradición de los Beatos y el Beato de Fernando I y Sancha. In: WILLIAMS, John et al. Beato de Fernando I y Sancha. Barcelona: M. Moleiro, 2006, p. 49. 
Estrutura é diferente de espaço, assemelha-se mais à ideia arquitetônica de construção com redes associativas e correlações dos elementos constituintes. Dessa constituição estrutural, o ornamento é parte fundante. Na medida em que afeta e é afetado pela imagem, o ornamento pode exercer diferentes funções, que não apenas a decorativa no sentido mais estrito. Pensemos em por que as linhas dos entrelaços são em ouro e por que foram escolhidas para compor o espaço entre as letras e encontraremos outras funções que não se reduzem a sua disposição formal, como veremos a seguir.

É nesse sentido que Bonne traz o termo ornamental para o estudo do ornamento na imagem medieval, quando este ultrapassa o domínio de motivos, de composições repetitivas, para constituir-se como um modus operandi, ou seja, o modo de funcionamento da ornamentação.

Se adotarmos como categoria fundamental o ornamental, e não o ornamento ou a ornamentação, é para sublinhar que não o designamos como um domínio ou um tipo de objeto particular e bem situado na arte medieval, mas como um modus operandi em que a função estruturante é susceptível de atravessar todos os gêneros. ${ }^{172}$

O ornamental configura-se como um "poder", aquilo que a ornamentação pode fazer, as várias funções que pode vir a assumir, podendo atravessar todos os níveis da imagem, desde os mais figurativos e representacionais aos mais abstratos e simbólicos. Aqui consideramos o ornamental como potência, em sua capacidade de ação, em sua possibilidade e poder de modificar-se ou ser modificado pelo contexto no qual se insere, pois suas formas e significados dependem de um contexto não apenas formal-imagético, mas também sociocultural. O ornamental pode tomar posse da imagem, participar da composição e vir a exercer a funcionalidade a que lhe é pedido celebrar. ${ }^{173}$

O modo como o ornamental se porta ao assumir determinada função define-se como ornamentalidade. Ou seja, um termo que qualifica determinado elemento com uma característica de função ornamental: a ornamentalidade das cores, a ornamentalidade dos entrelaços, a ornamentalidade medieval. A ornamentalidade liga-se, portanto, à qualidade de ser ornamental, de se apresentar como ornamental, como situação. A palavra

\footnotetext{
${ }^{172}$ BONNE, Jean-Claude. De l'ornemental dans l'art médiéval (VIIè - XIIè siècle): Le modele insulaire. In: SCHMITT, Jean-Claude; BASCHET, Jérôme (orgs). L'image: Fonctions et usages des images dans l'Occident médiéval. Paris: Le Léopard d'Or, 1996, p. 213, tradução nossa.

${ }^{173}$ Recordemos dos múltiplos significados do termo ornamentum, que inclui, em suas declinações, a capacidade de honrar, celebrar o objeto que orna.
} 
ornamentalidade, se pensada a partir de sua construção morfológica, define-se como o estado ou situação de ser ornamental devido ao sufixo "-idade".

A diferença entre ornamental e ornamentalidade encontra-se, de certo modo, na própria funcionalidade. Enquanto o ornamental é potência, a ornamentalidade é a situação, o ornamental posto em ação. O ornamental se expressa como substantivo e no poder de exercer funções, como potência. A ornamentalidade expressa propriamente qualidade, porta-se como um advérbio, que modula o caráter de um elemento ser ornamental, bem como é a própria condição para que a ação ornamental seja exercida.

Portanto, podemos dizer que o ornamento e a ornamentação estão para a forma assim como o ornamental e a ornamentalidade estão para a função. Em outras palavras, todos os quatro conceitos consideram a questão formal, contudo, no ornamental e na ornamentalidade, propostos por Bonne, a forma é ponderada junto com a funcionalidade, com os sentidos. Essa abertura do termo é um marco para a teoria do ornamento, que nos permite tratar das funções ornamentais na imagem do Beatus de Facundus. Funções estas que serão abordadas ao longo dos capítulos.

Retornemos à imagem do f. 7. A uma primeira vista, o labirinto não parece ser de difícil leitura (encontro e formação da frase de doação), até que somos levados a pensar o tema embrenhado entre os motivos ornamentais, que forma uma complexa trama. Há um jogo dinâmico e paradoxal na ação das linhas, o qual busca uma unicidade da imagem em uma só trama ao mesmo tempo em que individualiza seus elementos, principalmente os quadradosletra. Essa unicidade é reforçada, em primeiro lugar, pela forma com que a imagem se destaca no espaço da página. Diferencia-se do entorno através de uma larga borda ornamentada que se constrói de modo solidário à economia geral da imagem - faz uso da mesma gama de cores, de ouro e de formas entrelaçadas e arredondadas. A continuidade da linha que compõe a borda forma um retângulo de $30 \mathrm{~cm}$ de altura e 21 de largura, acrescido de dois centímetros na altura e na largura pelas formas semicirculares de um centímetro de raio. A imagem cria um jogo de abertura pelas curvas dos entrelaços e fechamento em formas geométricas. As arestas de cada um dos quatro quadrados, localizados nos cantos da borda, deixam-nos sem saída, mas nos permitem entrar na imagem pela aresta interna. É por essa entrada que observamos que a linha mais interna da larga borda da imagem é semelhante em matéria à linha que percorre entre os pequenos quadrados das letras, o que nos faz crer que se trata da mesma linha. É nesse "fazer crer" que o paradoxo acontece. As semelhanças materiais dão à imagem um corpo uno, costurado por essa linha em ouro, mas quando reduzimos o olhar às 
regiões específicas da imagem, encontramos o ornamento que individualiza aquilo que orna. Voltemo-nos ao centro da imagem, distante da borda, com o foco na letra $\mathrm{F}$ do nome de Fredenandus (quadrante 12x12).

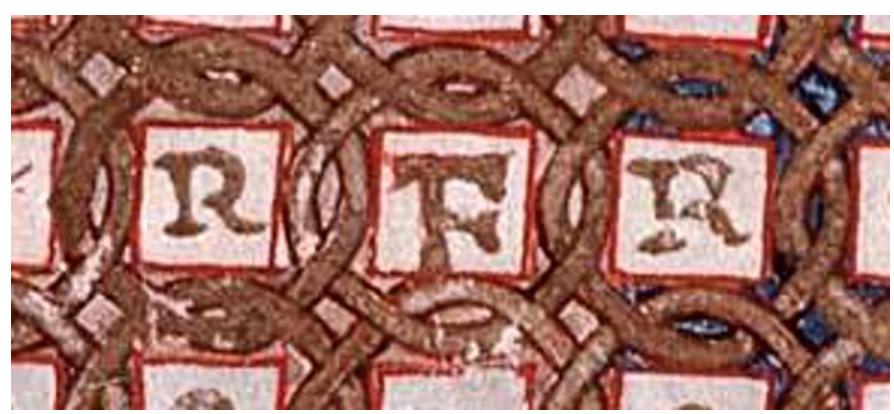

Figura 15. Detalhe do f. 7, letra F (Fredenandus) e ornamento em ouro. Fonte: www.bne.es (recorte da autora)

A linha próxima à borda aparentava ser uma única linha, que costura toda a imagem e individualiza-se em 840 argolas entrelaçadas, feitas em ouro e circundadas por uma borda em marrom escuro. A individualização reforça a unidade dos quadrados que circundam as letras e a tensão criada entre as bordas (da imagem, das argolas e dos quadrados) cria limitações que diferenciam o dentro do fora, mas que permitem uma relação de contiguidade. A reciprocidade entre os elementos ornamentais e aquilo que circundam, ou seja, o poder de um interferir no outro, justifica a escolha de falarmos em borda e não em moldura. ${ }^{174}$ A moldura, elemento já arraigado em nosso imaginário pós-renascentista, cerca, encerra, delimita um objeto de diferente natureza. É a moldura de madeira que prende a tinta e a narrativa ilusionista na parede. A borda medieval frisa uma delimitação ao mesmo tempo em que se mantém em diálogo com o funcionamento da imagem. Seu esforço em delimitar reforça a existência de detalhes do ornamento que vão ao sentido contrário, como as pequenas estruturas pontiagudas entre cada entrância dos semicírculos da borda. Elas apontam para fora da imagem, feitas também de ouro, como os entrelaços dos quadrados e do preenchimento central, aparentam ser extensões da mesma linha, que passou por baixo da linha mais externa.

${ }^{174}$ BONNE, Jean-Claude. Les ornements de l'histoire (à propos de l'ivoire carolingien de Saint Remi). Annales HSS, année 51, n. 1, p. 37-70, jan/fév. 1996, p. 40. Disponível em: <www.persee.fr/doc/ahess_03952649_1996_num_51_1_410833>. Acesso em: 15 out. 2015. 
O ponto de maior tensão entre a borda da imagem e esse preenchimento interno ${ }^{175}$ encontra-se no próprio limite entre um lugar e outro. Na linha mais interna da borda, a qual se liga à aresta interna dos quadrados da borda, vemos que há uma diferenciação interessante na comunicação entre a borda e as argolas que enquadram as letras. Na parte superior e esquerda da imagem, a borda interna evidencia a separação entre o que é borda e o que é porção interna da imagem, através de uma fina linha contínua e vermelha, que acompanha a borda na extensão dos dois comprimentos (linha superior e linha à esquerda). ${ }^{176}$ A própria interrupção da costura das argolas, de seu fechamento, evidencia que a borda contém as argolas em seu interior, como limitação espacial (Figura 16). Uma organização que é diferenciada das porções inferior e direita da borda. Na Figura 17, observamos o canto superior direito que, como o canto inferior esquerdo da imagem, é o local de mudança de uma economia à outra.

Nessa passagem, o ornamento cria campos permissivos para diálogos entre linhas, entrelaços e cores. A presença de um estreito campo de cor azul claro ao entorno da borda permite que a linha que sai (ou entra, ou caminha, ou costura) do quadrado no canto superior direito da imagem possa ter seu corpo evidenciado como parte das duas linhas que formam a borda da imagem (linha externa e interna à imagem), por uma questão de contraste. ${ }^{177}$ Esse campo de cor azul claro aparece nos limites da borda na lateral direita e inferior da imagem, mas se ausenta nas porções superior e esquerda da borda. Seria uma escolha aleatória? Muito provavelmente não. Há uma diferença substancial na dinâmica dos quatro lados da borda com as argolas que circundam. Na porção direita (Figura 17), a linha interna da borda interrompe as argolas no limite externo do quadrado das letras, tanto que vemos o encostar da linha vermelha dos quadrados no ouro da borda. Como se a argola, que na porção superior esquerda termina por baixo da borda (Figura 16), na porção direita, terminasse por cima. Mas ela não termina. Há uma fusão dos corpos da linha da argola com a linha da borda, ambas em ouro. A presença, ou ausência, do estreito campo de cor azul claro fortifica a diferenciação entre as duas porções da imagem. Distanciemo-nos dos locais de contato entre uma e outra economia,

\footnotetext{
${ }^{175}$ Preenchimento não no sentido de acréscimo para ocupar um espaço que antes era vazio e que depois se tornou cheio. A dedicação do ornamento ao preenchimento da superfície de inscrição diz mais das relações que trava no processo de costura que no seu próprio corpo aparente entre uma coisa e outra.

${ }^{176}$ Seria a cor vermelha da linha uma contaminação pelo ornamento que se encontra dentro da borda da imagem, aquele da figura 16, e que encosta na limitação da borda?

${ }^{177}$ Não adentraremos de fato na questão das cores aqui, deixamos a discussão para o capítulo 4, destinado ao estudo da cor como ornamento. Também colocamos em nota que há questões nessa imagem que ainda exigem tempo de trabalho dentro do processo que é uma pesquisa. Ideias sobre as últimas camadas de inscrição que começaram a ser trabalhadas, que não cabem ainda a este espaço dissertativo, mas que certamente, e em breve, serão disponibilizadas no site <www.notamanuscrita.com>.
} 
como fizemos ao sair da borda ao centro, e observaremos no canto inferior direito o mais alto grau de variação e fusão das linhas (Figura 18).

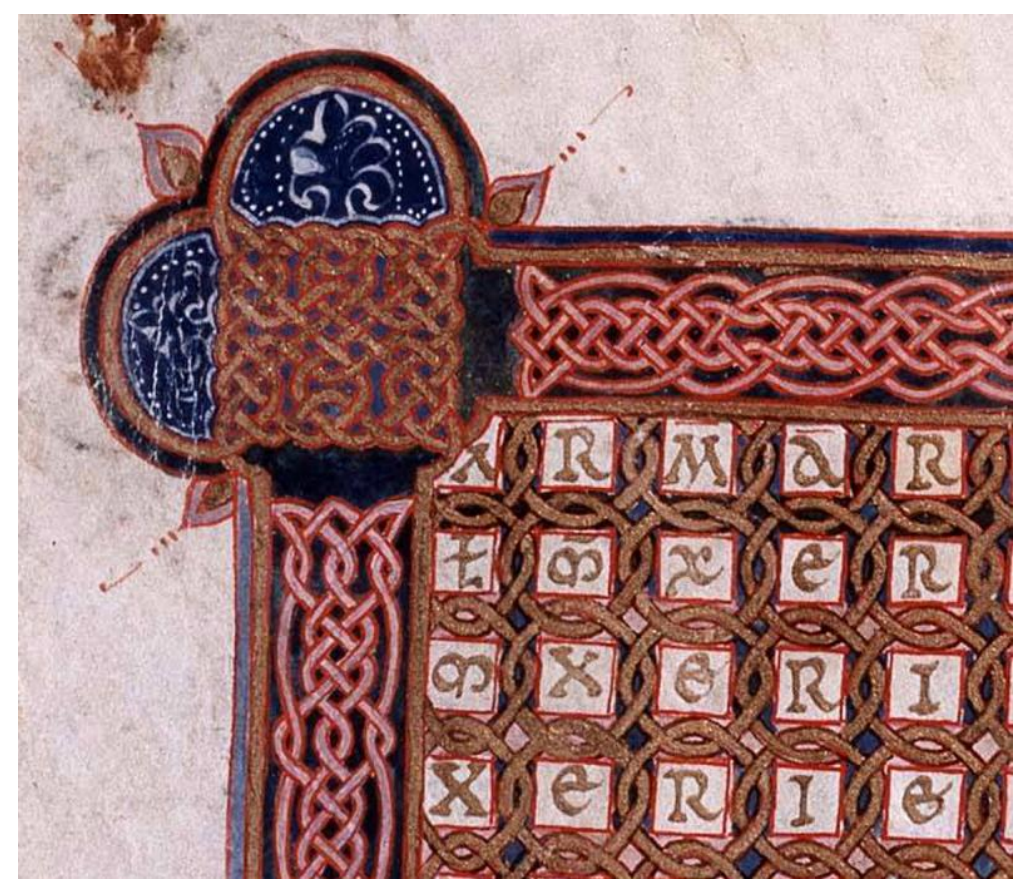

Figura 16. Beatus de Facundus, f. 7, canto superior esquerdo. Fonte: www.bne.es (recorte da autora)

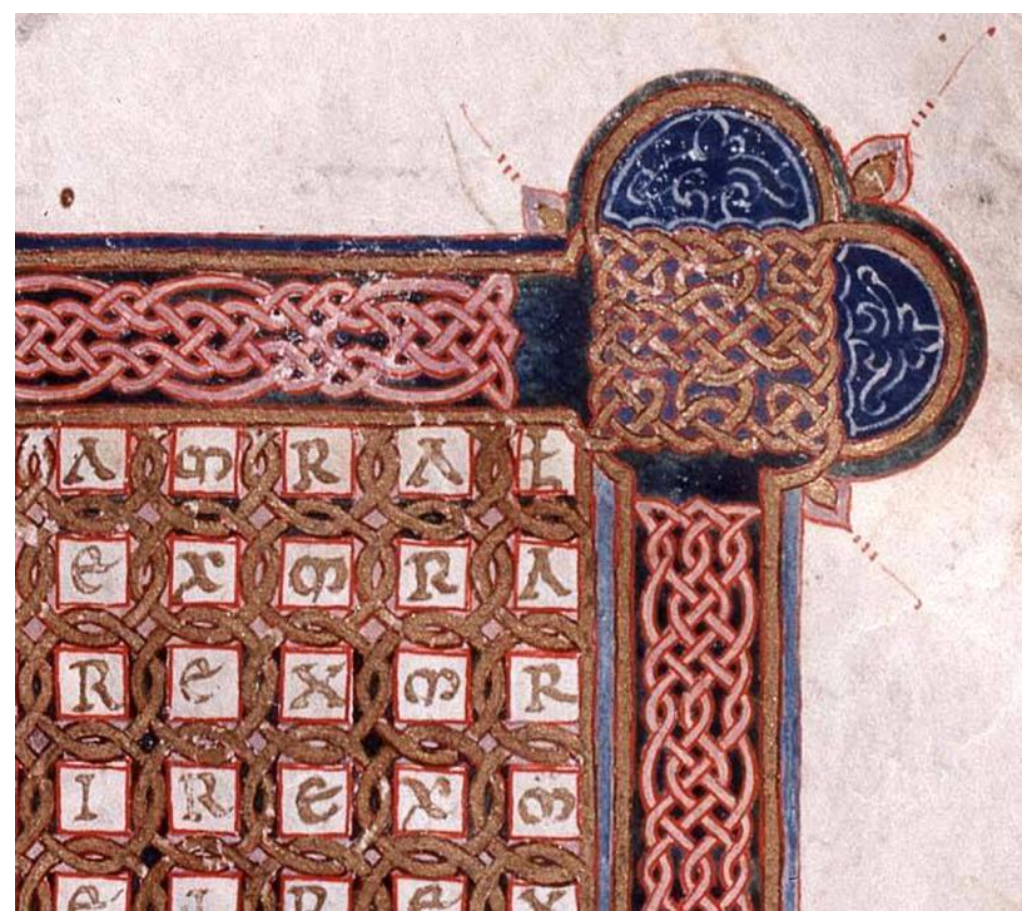

Figura 17. Beatus de Facundus, detalhe f. 7, canto superior direito. Fonte: www.bne.es (recorte da autora) 


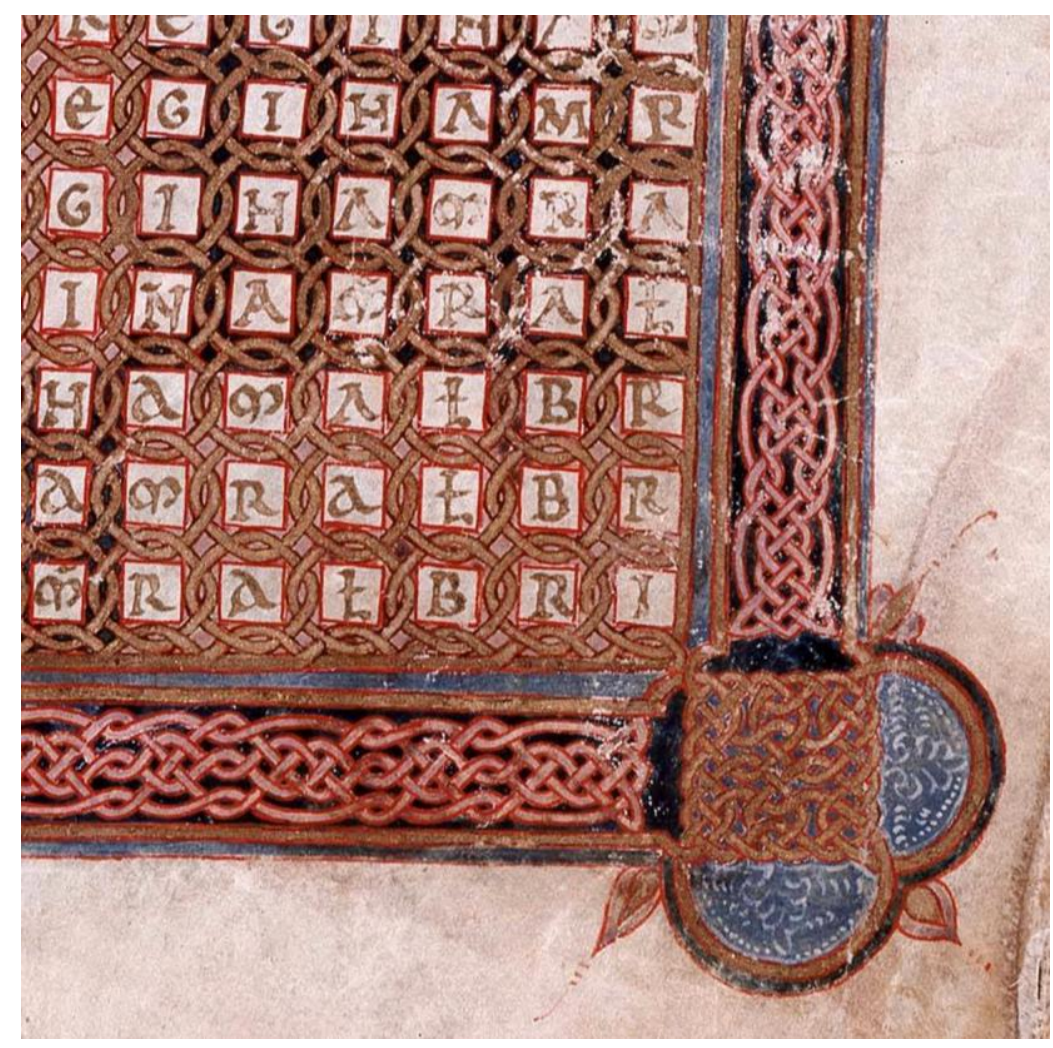

Figura 18. Beatus de Facundus, detalhe f. 7, canto inferior direito. Fonte: www.bne.es

Se, no contato entre as argolas e a borda na lateral direita, uma tornou-se parte da outra, ao menos quanto à primeira coluna de argolas, na parte inferior da imagem, as argolas que circundam a última linha de letras não são interrompidas pela borda, nem por uma sobreposição sobre seu corpo, nem por uma elevação, as argolas estão fechadas, completas. Elas são presas por uma linha que é, ao mesmo tempo, borda (por contato e fusão, como na lateral direita) e também argola (por sua semelhança formal às outras argolas). Não podemos dizer que são argolas interrompidas, porque apesar da semelhança, a linha é uma fusão de borda e argola, que é outra coisa que não funciona nem como borda (limite), nem como argola (estruturadora de quadrados e letras), a não ser que essas linhas pressuponham um tapete de letras que continua além da imagem visual. Seu funcionamento é próprio da fusão, do segurar, do arremate da trama de argolas dentro do tapete de letras.

Em nenhum momento negamos a forma do ornamento. Todo o ritmo da imagem dialoga com esse corpo estrutural. ${ }^{178}$ A linha, em sua forma contínua ou finalizada em pontos de costura, trabalha na imagem para fazê-la funcionar. Está longe de ser um elemento supérfluo. Os entrelaços tornam a imagem um grande tapete ornamental, em que tudo o que

\footnotetext{
${ }^{178}$ Sobre o ornamento como estrutura, ou na função de estrutura, ver capítulo 5.
} 
está dentro, e fora, nesse jogo de costura, assuma também um caráter ornamental. A letra, envolvida pelo ornamento, é também ornamental, ao mesmo tempo em que é letra, limitada pela própria ornamentação, um símbolo gráfico à espera da costura de seu corpo com outras letras para formarem sentidos que dirão sobre quem encomendou a obra.

Ainda em nossa observação sobre a borda ornamental e seu diálogo com toda a imagem, temos, além dos quatro quadrados e os oito semicírculos, um conjunto de dez ornamentos de entrelaços, distribuídos em dois na borda superior e dois na inferior, mais três em cada borda lateral. ${ }^{179}$ Estes ornamentos podem ser vistos de modo isolado na figura 16 . A separação entre entrelaços feitos em ouro e entrelaços, miniados em cor púrpura, afasta a borda do preenchimento central, cria tensões dentro da imagem. A sequência do ornamento miniado em cor púrpura é interrompida pela presença de seis cabeças humanas, de perfil nas bordas laterais e de frente na superior e inferior. Todas convergem para o centro da imagem, quer dizer, como se os corpos, se existentes, se desenvolveriam em direção ao centro da composição. Mais uma vez, somos guiados para dentro da imagem. A disposição das seis cabeças também não é gratuita. Ao traçarmos linhas imaginárias entre elas, observamos que o encontro das linhas de união das cabeças superior e inferior com as primeiras cabeças laterais forma o centro de uma cruz, onde, justamente, encontramos a letra $F$ do nome de Fredenandus.

Para manter a proporção de tamanho destes ornamentos laterais em uma média de 7,8 a $8,2 \mathrm{~cm}$ e a mesma distância entre as cabeças, a letra $\mathrm{S}$ de Sancha no quadrante $29 \times 12$ (linha/coluna) não coincide com a linha que une as cabeças laterais inferiores. Um erro de localização ou uma intenção de variedade que permite a formação de uma cruz sobre o nome de Fernando I? Caso o nome de Sancha estivesse sobre a linha 24, entre as duas cabeças inferiores, não teríamos uma cruz, mas seis quadrados formados por onze linhas (em subtração às duas linhas utilizadas pela inscrição)

\footnotetext{
${ }^{179}$ Quando separamos a borda em porções superior, inferior e de duas laterais, não a separamos como um objeto que perde sua continuidade, mas em um sentido prático de localização verbal-visual.
} 


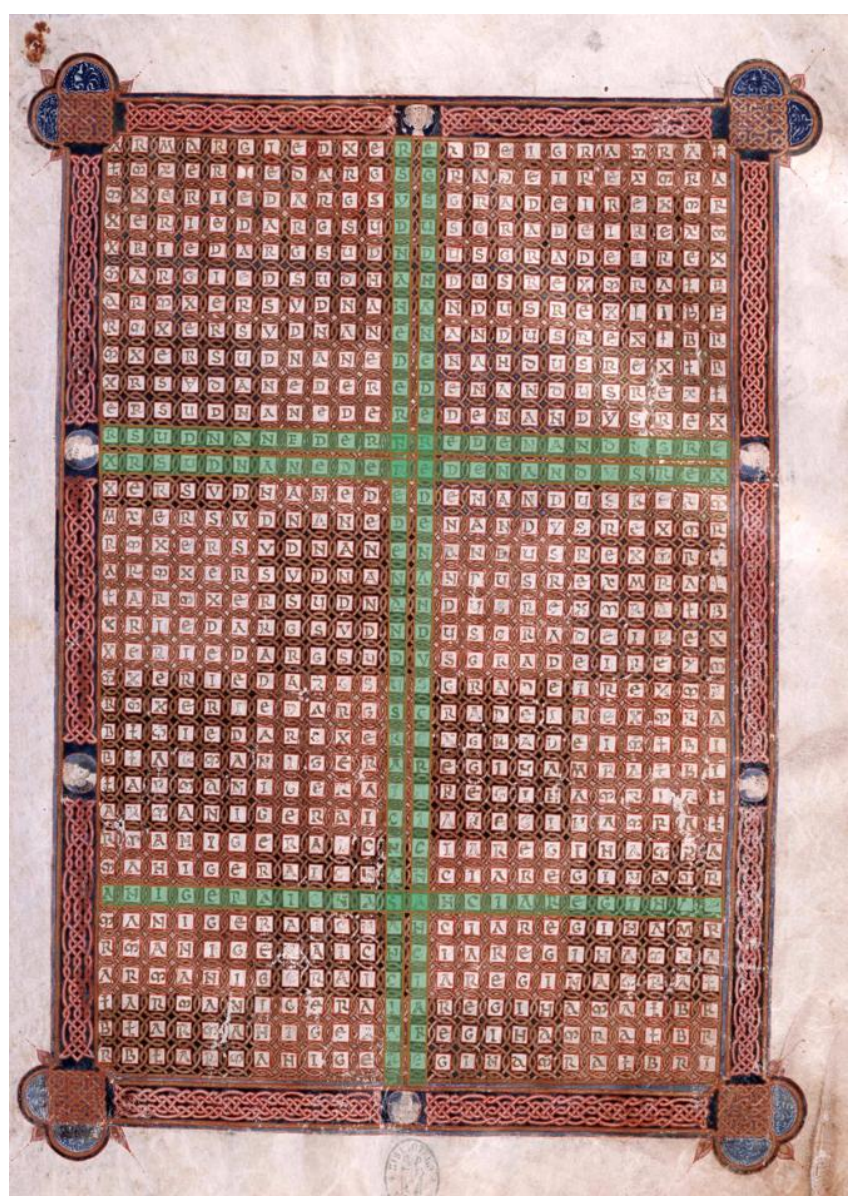

Figura 19. Beatus de Facundus, f. 7, esquema. Fonte: www.bne.es (modificado pela autora)

Mais uma vez, o ornamento, figurativo ou abstrato, dialoga com a construção e a narrativa da imagem. A beleza e a honra conferidas devem-se aos jogos rítmicos, à presença do ornamento e de sua materialidade, como no uso do ouro e da cor púrpura, ${ }^{180}$ e pelas relações temporais estabelecidas pelo ornamento. Não esqueçamos que os labirintos são herança da Antiguidade e que essas cabeças em muito se assemelham aos camafeus antigos e aos símbolos imperiais centroeuropeus. ${ }^{181}$ Elementos que, quando associados aos nomes dos doadores, funcionam como um símbolo de realeza que reforçam a dedicatória. Os entrelaços, encontrados em outras culturas, como a celta e carolíngia, podem embelezar e conferir honra pela sua presença e valor de tradição, mas o diálogo com a imagem pode ultrapassar as relações decorativas para exercer outras funções de ordem simbólica. O ornamental trabalha na imagem de modo conveniente (decet), assume funções que lhe é pedido celebrar.

\footnotetext{
${ }^{180}$ Sobre o ouro e a cor púrpura, conferir capítulo 4.

181 SÁNCHEZ MARIANA, Manuel. La tradición de los Beatos y el Beato de Fernando I y Sancha. In: WILLIAMS, John et al. Beato de Fernando I y Sancha. Barcelona: M. Moleiro, 2006, p. 47
} 
"Por conseguinte, a decoração ornamental (ou não) pode regularmente exercer função de emblema do status, da posição ou do prestígio de seu detentor e da identidade social dos seus dependentes materiais ou espirituais" ${ }^{182}$ A honra concebida pelo ornamental incide não apenas na imagem, mas no manuscrito como uma imagem-objeto, bem como é cedida aos detentores do manuscrito. ${ }^{183}$ A ornamentalidade respeita uma conveniência axiológica em que o caráter estético do ornamento adéqua-se ao valor suposto do objeto. Recordemos uma das implicações da palavra ornamentum como ornamenta regia, uma insígnia de poder real ou imperial.

Ao mesmo tempo em que o ornamento é quase dessemantizado, ele é, também, segundo Bonne, um quase-signo. ${ }^{184}$ É aquilo que se assemelha a um signo, mas que não confere sentido até que se ponha a trabalhar na imagem, como uma engrenagem que pode ser acionada, isto é, o ornamental possui a potencialidade de trabalhar como um signo, mas até que lhe seja exigido, até que outros elementos dialoguem e atualizem essa potencialidade em função, o ornamental ainda não é um signo propriamente dito. É pela presença dos nomes dos comitentes, pelo trabalho dessa imagem do f. 7, que o ornamental serve de símbolo real.

Segundo Pastoureau, o pensamento analógico está intimamente relacionado à construção do símbolo na Idade Média, pois é por uma analogia apoiada na semelhança, mais ou menos vaga, que se estabelece um vínculo entre uma coisa aparente e alguma coisa oculta. ${ }^{185}$ Um elemento da imagem, no nosso caso os camafeus e os entrelaços, pode se revestir de função simbólica e evocar relações além da que a princípio pretende mostrar (ou apontar). "O símbolo é sempre mais vigoroso e mais verdadeiro do que a pessoa ou a coisa real que ele tem por função representar, porque na Idade Média a verdade situa-se fora da

\footnotetext{
${ }^{182}$ BONNE, Jean-Claude. De l'ornemental dans l'art médiéval (VIIè - XIIè siècle): Le modele insulaire. In: SCHMITT, Jean-Claude; BASCHET, Jérôme (orgs). L'image: Fonctions et usages des images dans l'Occident médiéval. Paris: Le Léopard d'Or, 1996, p. 221, tradução nossa.

${ }^{183}$ Para compreendermos melhor essa questão, basta pensarmos em quantos manuscritos e objetos luxuosos não foram fragmentados, arrancados de seu local de origem por serem objetos de desejo, de ostentação. Se fosse possível, hoje, o labirinto do f. 7 estar em posse de uma pessoa comum e não de uma instituição como a Biblioteca Nacional, muito provavelmente ele estaria dentro de uma caixa de vidro, exposto para que todos admirassem a posse do detentor. Talvez não estejamos tão distantes da ideia de honra que um objeto ornamentado confere.

${ }^{184}$ BONNE, Jean-Claude. De l'ornemental dans l'art médiéval (VIIè - XIIè siècle): Le modele insulaire. In: SCHMITT, Jean-Claude; BASCHET, Jérôme (orgs). L'image: Fonctions et usages des images dans l'Occident médiéval. Paris: Le Léopard d'Or, 1996, p. 233.

${ }^{185}$ PASTOUREAU, Michel. Símbolo. In: LE GOFF, Jacques; SCHMITT, Jean-Claude. Dicionário temático do Ocidente medieval. São Paulo: Edusc/Imprensa Oficial, 2002, v. 2, p. 495-510, p.497.
} 
realidade, em um nível que lhe é superior". ${ }^{186}$ Como se para chegarmos à inscrição dos comitentes, antes precisássemos passar por ela em outro plano semântico, através do desvio e abri-la para além das palavras, de modo ornamental. Apresentar o rei Fernando I e a rainha Sancha de figurados com o livro nas mãos e coroas na cabeça pode ser de ordem semelhante a uma fragmentação do nome em letras entre camafeus e ornamentos em ouro e púrpura. E pode ainda ecoar como um sentido de renovatio de uma tradição reinterpretada pelo uso de elementos da Antiguidade ou de outras culturas a que se quer associar. "A estratificação dos registros faz com que o sentido ou a significação de um ornamento possa transcender as 'condições geo-históricas' de sua reaparição enquanto requer outros registros que condicionam historicamente sua reapropriação inédita". ${ }^{187} \mathrm{O}$ ornamento, por não ser propriamente da ordem dos sentidos, pode ser transposto de um local e tempo a outro, como afirmou Owen Jones em sua "Gramática do Ornamento", mas requer condições para que sua aparição faça sentido. As formas guardam sentidos polivalentes, a depender da dinâmica interna da imagem e, ainda, frisamos, a depender do contexto sociocultural da encomenda.

Afinal, o que implicava uma encomenda do Comentário ao Apocalipse de Beato de Liébana na Hispânia?

O Apocalipse, do grego apokálypsis ("revelação"), marca a revelação de Deus a João sobre o destino do mundo. Na revelação das coisas ocultas, só por Deus conhecidas, João as vê e traduz em valores simbólicos (a verdade que se realiza fora de si). ${ }^{188}$ A escrita alegórica do texto possibilitou aos Santos Padres explorarem em seus Comentários diferentes relações interpretativas entre o Livro do Apocalipse, outras passagens bíblicas e a conduta moral na vida terrena. Para os exegetas, o Apocalipse atendia, na Alta Idade Média, a uma referência ao Fim do Mundo e como uma recapitulação simbólica da história da Igreja, feita por Beato

\footnotetext{
${ }^{186}$ PASTOUREAU, Michel. Símbolo. In: LE GOFF, Jacques; SCHMITT, Jean-Claude. Dicionário temático do Ocidente medieval. São Paulo: Edusc/Imprensa Oficial, 2002, v. 2, p. 495-510, p. 504.

${ }^{187}$ BONNE, Jean-Claude et al. Y a-t-il une lecture symbolique de l'ornement? Perspective, 1 | 2010, 27-42, p. 33. Disponível em: 〈http://perspective.revues.org/1206>. Acesso em: 11 dez. 2015.

${ }^{188}$ Beato de Liébana, na explanatio sobre o Ap 2, 12-17, explica que a "Santa Escritura deve ser interpretada de três maneiras: primeiro, que se entenda historicamente; segundo, figuradamente, e terceiro, misticamente. Historicamente segundo a letra, tropologicamente segundo o conhecimento moral, misticamente segundo a inteligência espiritual. Portanto convém a Igreja católica compreender a fé de tal maneira, que devemos ler as Escrituras historicamente, interpretadas moralmente e entendê-las espiritualmente. CAMPO HERNÁNDEZ, Alberto del; FREEMAN, Leslie G.; GONZÁLEZ ECHEGARAY, Joaquín (ed.). Beato de Liébana. Obras completas y complementarias. Edição bilíngue do latim ao castelhano. Madrid: Biblioteca de Autores Cristianos, 2004, v. 1, p. 216-217.
} 
através da Recapitulatione - sexta regra de interpretação bíblica proposta por Ticônio, utilizada em nove livros dos doze que compõem o Beatus. ${ }^{189}$

A angústia e espera pelo Fim era uma constante para todos os fiéis, laicos ou clérigos. Segundo Hilário Franco Júnior, ${ }^{190}$ a angústia estava ligada especialmente ao modo como os medievais pensavam o tempo. A medida do tempo pertencia mais aos teóricos e estudiosos que ao mundo laico. O tempo existia, mas era sentido de formas diferentes, geralmente cíclica, como as estações e os plantios. O calendário mais dizia da sociedade que o adotava que do tempo e sua medição. Medir o tempo significava ordenar os períodos de festas, as fases de jejum, os momentos de atividades profanas e a dedicação ao sagrado, e outras atividades importantes. ${ }^{191}$ Mas a angústia pelo fim não se devia a uma incapacidade qualquer de medir o tempo. ${ }^{192}$ Assim como um homem envelhece e morre, o mundo também morreria. Associações entre microcosmo e macrocosmo herdadas pelo cristianismo primitivo da cultura clássica. ${ }^{193} \mathrm{O}$ fiel está sempre à espera porque seu objetivo terrestre é esperar para ser acolhido no Reino do Senhor. Não se sabe o momento da vinda de Cristo, o início da era da salvação, e nem seria preciso saber, porque o próprio Cristo alertara que "Não compete a vós conhecer os tempos e os momentos que o Pai fixou com sua própria autoridade." (Ato 1,7).

A angústia é reforçada pela indeterminação. Apesar do alerta, muitos pensadores especularam o momento final. Beato de Liébana via a iminência do fim do mundo no ano 800, tema que explora no capítulo IV do Comentário ao Apocalipse. Contudo, Segundo

\footnotetext{
${ }^{189}$ CAMPO HERNÁNDEZ, Alberto del; FREEMAN, Leslie G.; GONZÁLEZ ECHEGARAY, Joaquín (ed.). Beato de Liébana. Obras completas y complementarias. Edição bilíngue do latim ao castelhano. Madrid: Biblioteca de Autores Cristianos, 2004, v. 1, p. 15. Dos 12 livros que compõem a parte essencial do Beatus, os trechos do Apocalipse seguidos de comentários, apenas o livro I, II e IV não utilizam, segundo Alberto Del Campo, a regra de Recapitulatione. Para o autor, a aplicação da regra por Beato no Apocalipse transforma-se mais em uma repetição, em que se diz o mesmo de outras maneiras. De todo, são recapitulações que referenciam momentos da história da Salvação: “origem (nascimento, paixão, primeira vinda de Cristo), tempo intermediário (tempo da Igreja) ou dos últimos tempos (perseguições finais, segunda vinda de Cristo, Juízo)”.

${ }^{190}$ FRANCO JÚNIOR, Hilário. O ano 1000. São Paulo: Companhia das Letras, 1999, p. 31.

${ }^{191}$ FRANCO JÚNIOR, Hilário. O ano 1000. São Paulo: Companhia das Letras, 1999, p. 33.

192 O uso da palavra incapacidade parece que sempre será arbitrário. Incapaz segundo quais referenciais? A medida do tempo no medievo era, certamente, diferente da nossa cronometrada (mesmo que ainda busquemos um tempo também kairológico). Guiada, às vezes, pela oração, pela espera da queima de uma vela, e mesmo por relógios, o tempo, como medida, também existia no medievo. Sobre a medida do tempo no medievo, ver ROSSUM, Gerhard Dohrn-van. Les 'horologia' médiévaux et la mise au point de l'horloge à rouages. In: L'histoire de l'heure: l'horlogerie et l'organisation moderne du temps. Paris: Éditions de la Maison des Sciences de l'homme, 1997, p. 47-130.
}

193 ALVEMY, Marie-Thérèse. Le cosmos symbolique du XII ${ }^{\mathbf{e}}$ s. Paris: Archives d'histoire doctrinale et littéraire du Moyen Âge, 1953, p. 31-81. 
Echegaray, ${ }^{194}$ o Beato de Liébana interpretava alegoricamente a matemática da espera, sua intenção maior para o texto do Apocalipse era aludir ao triunfo final de Cristo e não mostrar quando o Dia chegaria, pelas indicações temporais dadas pelo texto. ${ }^{195}$ Beato indica uma data, mas, logo em seguida, afirma, "É incerto para a compreensão humana o que resta de tempo do mundo". ${ }^{196}$ Para Franco Jr., a proximidade da escrita do Comentário ao Apocalipse e o Fim do Mundo em apenas 14 anos relacionava-se com as tensões existentes na sociedade peninsular com a invasão muçulmana e "[...] por isso [Beato de Liébana estaria] propenso a diminuir o número de anos que faltavam para a expulsão dos infiéis e o estabelecimento do reino de Cristo". ${ }^{197}$

Mais importantes que a data, eram os sinais da iminência. $\mathrm{O}$ começo do fim, segundo a Escritura, se dará com a chegada dos quatro cavaleiros do Apocalipse na abertura do primeiro

${ }^{194}$ ECHEGARAY, Joaquín González. Beato de Liébana y su mundo. In: WILLIAMS, John et al. Beato de Fernando I y Sancha. Barcelona: M. Moleiro, 2006, p. 22 e seguintes.

${ }^{195}$ Posição também defendida por John Williams, baseado na omissão do texto do Apocalipse e das explanatios o trecho do versículo 5 "O restante dos mortos não tornarão à vida até que os mil anos acabassem". A omissão reforçaria o não compartilhamento, por Beato de Liébana, da crença na literalidade dos mil anos. WILLIAMS, John. The illustrated Beatus: a corpus of the illustrations of the Commentary on the Apocalypse. London: Harvey Miller, 1994, v. 1, p. 117. Segundo Hilário Franco Júnior, “[...] foi a interpretação simbólica que se tornou, depois de alguma hesitação, nos séculos III e IV, a posição oficial da Igreja. Sobretudo graças a Santo Agostinho [...]", para quem já se vivia nos "mil anos com Cristo", pois simboliza o tempo da Igreja. FRANCO JR, Hilário. O ano 1000: Tempo de medo ou de esperança. São Paulo: Companhia das letras, 1999, p. 41.Beato de Liébana também considerava este período de mil anos como uma alusão ao triunfo de Cristo e de sua Igreja até o fim do mundo. Foi dessa associação repetida ao longo da Idade Média que aceitava-se a correspondência da Idade do Mundo em seis etapas, a mesma quantidade de dias da Criação. CAMPO HERNÁNDEZ, Alberto del; FREEMAN, Leslie G.; GONZÁLEZ ECHEGARAY, Joaquín (ed.). Beato de Liébana. Obras completas y complementarias. Edição bilíngue do latim ao castelhano. Madrid: Biblioteca de Autores Cristianos, 2004, v. 1, p. 369. Santo Agostinho fez a seguinte distinção quanto às Idades do Mundo: a infantia correspondia ao período entre a criação de Adão ao Dilúvio; pueritia, do Dilúvio a Abraão; adolescentia, de Abraão a Davi; juventus, de Davi ao Exílio da Babilônia; aetas senior, do Exílio ao nascimento de Cristo; senectus, de Cristo ao Fim dos Tempos. A sétima e última etapa, situada para além do tempo terreno, corresponderá ao "fim sem fim", ao eterno descanso sabático. A noção agostiniana de Idades do Mundo (p.35-36) prevaleceu até o século XII. "A teologia medieval identificava seu presente histórico com a sexta idade, que tinha o Apocalipse diante de si, porém sem ter a intenção de datá-lo, Isidoro de Sevilha (560-636) e Beda, o Venerável (672-735), por exemplo, aceitavam a correspondência entre os seis dias da Criação e as seis idades do mundo, mas atribuíam a cada idade, inclusive à sexta, uma duração diferente" FRANCO JR, Hilário. O ano 1000: Tempo de medo ou de esperança. São Paulo: Companhia das letras, 1999, p. 18.

${ }^{196}$ CAMPO HERNÁNDEZ, Alberto del; FREEMAN, Leslie G.; GONZÁLEZ ECHEGARAY, Joaquín (ed.). Beato de Liébana. Obras completas y complementarias. Edição bilíngue do latim ao castelhano. Madrid: Biblioteca de Autores Cristianos, 2004, v. 1, p. 368-369.

${ }^{197}$ FRANCO JR, Hilário. O ano 1000: Tempo de medo ou de esperança. São Paulo: Companhia das letras, 1999, p. 38. Não podemos negar os impactos da presença muçulmana na península ibérica e de sua associação ao contexto de produção de Beato de Liébana, contudo, devemos nos questionar até que ponto essa consideração não reduz os sete séculos de presença muçulmana a uma ideia errônea de luta intensa e contínua, que negaria os pequenos âmbitos de convivência relativamente pacífica e de contaminação cultural. Além disso, a presença muçulmana jamais explicaria por si só a encomenda de tantas cópias da obra de Beato de Liébana, até o século XVI. 
dos sete selos (Ap 6, 1-8). ${ }^{198} \mathrm{Na}$ explanatio, Beato de Liébana relaciona os quatro cavaleiros aos símbolos de guerra (cavalo vermelho), fome (cavalo negro) ${ }^{199}$ e morte (cavalo pálido). ${ }^{200}$ Soma-se a estes três, o cavalo branco, que é a palavra de predicação enviada ao mundo junto do Espírito Santo. ${ }^{201}$ Males, que segundo Hilário Franco Jr., ${ }^{202}$ assombravam a Europa de fins do século X e XI e reforçavam a busca por proteção espiritual. Uma busca que se concentraria, no caso de dificuldades isoladas, pessoais, em jejuns, mortificações e peregrinações. Para as dificuldades coletivas, a proteção estaria relacionada à posse e encomenda de objetos mágicos e ritualísticos, que poderiam circular, ou não, em procissões, e protegeriam aqueles a seu redor, mesmo aqueles que não vissem o objeto. A presença é, por si só, mágica. O objeto podia relacionar-se também a um agradecimento, a uma garantia de segurança material e espiritual e para alcançar determinada graça. Hilário Franco Jr. define as relíquias como um exemplo privilegiado de objeto de graça e proteção. ${ }^{203}$

Fernando I não estava alheio a essas questões de seu tempo. Em 1063, vários objetos doados por ele e pela rainha Sancha foram doados ao monastério de São João Batista, que depois passou a ser chamado de Colegiata de Santo Isidoro, por acolher, naquele mesmo ano, as relíquias do santo, vindas de Sevilha. A doação fazia parte da reconstrução da igreja do monastério. Segundo Yarza Luaces, o empreendimento de artefatos de Fernando I possuía um

\footnotetext{
${ }^{198}$ Os sete selos do Apocalipse são a primeira de três séries de julgamentos de Deus. As sete trombetas são a segunda série de julgamentos (Ap 8, 6-21; 11, 15-19) e as sete taças a última série (Ap 16, 1-21). Os julgamentos são progressivos e se tornam mais severos à medida em que o fim dos tempos progride. Os primeiros quatro selos são os quatro cavaleiros do Apocalipse.

${ }^{199}$ A fome, a que Beato se refere em sua compilação é a fome espiritual e a mundana, ao fazer a relação com o texto de Lucas 21,11: "E como o Senhor tem a sua Igreja por todo o mundo, para sempre dar a conhecer, ele diz 'haverá fome em vários lugares". CAMPO HERNÁNDEZ, Alberto del; FREEMAN, Leslie G.; GONZÁLEZ ECHEGARAY, Joaquín (ed.). Beato de Liébana. Obras completas y complementarias. Edição bilíngue do latim ao castelhano. Madrid: Biblioteca de Autores Cristianos, 2004, v. 1, p. 341, tradução nossa.

${ }^{200}$ Segundo Franco Jr., o referido texto do Apocalipse não explicita a epidemia, mas poderia ser assim entendido em associação a Ezequiel 6, 11. "Eis o que diz o Senhor Deus: bate palmas, tripudia, e dize: Ah! Ah! sobre todas as abominações perversas da casa de Israel, que irá perecer pela espada, fome e peste". FRANCO JR., Hilário. O ano 1000. São Paulo: Companhia das Letras, 1999, p. 96. Essa relação com o livro de Ezequiel, proposta pelo autor, não aparece na explanatio de Beato de Liébana.

${ }^{201}$ No título da passagem, "Começa a explicação do livro IV do cavalo branco" (Incipit explanatio libri quarti de equo albo), destaca-se a presença do cavalo branco, mas pouco se fala sobre ele na explanatio. Ele está indiretamente presente em todas as relações feitas pelos Padres da Igreja, compiladas por Beato de Liébana, sobre os outros cavalos e o que eles representam. CAMPO HERNÁNDEZ, Alberto del; FREEMAN, Leslie G.; GONZÁLEZ ECHEGARAY, Joaquín (ed.). Beato de Liébana. Obras completas y complementarias. Edição bilíngue do latim ao castelhano. Madrid: Biblioteca de Autores Cristianos, 2004, v. 1, p. 338-346.

${ }^{202}$ FRANCO JR., Hilário. O ano 1000. São Paulo: Companhia das Letras, 1999, p. 63.

${ }^{203}$ Sobre o poder das relíquias ver BOCK, Nicolas. Reliques et reliquaires, entre matérialité et culture visuelle. Perspective, 2 | 2010, P. 361-368. Disponível em: <http://perspective.revues.org/1147>. Acesso em: $10 \mathrm{dez}$. 2014; SANCHEZ, Jean-Michel. Reliques et reliquaires. Paris: éditions Grégoriennes, 2009.
} 
duplo aspecto. ${ }^{204}$ Por um lado, marcava uma renovatio, ao dialogar com o passado alto medieval, por outro, era o início de um contato com o estilo românico. ${ }^{205}$ A reconstrução da igreja do monastério evidencia, de certa forma, essa duplicidade. Fernando I renovou a igreja, retirou-lhe o barro e os tijolos para refazê-la em pedra, ${ }^{206}$ ornou-a com artefatos religiosos, mas ainda a manteve semelhante à igreja de seu antecessor. Era uma igreja "arcaizante" e herdeira de Alfonso V, pai de Sancha.

\begin{abstract}
Não era a primeira vez que isto ocorria. Faz alguns anos que trabalham para o rei ou para a coroa diversos artesãos do marfim e iluminadores, alguns dos quais conheciam o que se vinha fazendo na Europa, embora não haviam renunciado ao que lhes oferecia a tradição hispânica. [...] Como ornamenta altariorum, adornos dos altares, havia um frontal de ouro puro, enriquecido com esmeraldas, safiras e todo tipo de pedras preciosas. Logo, três frontais de prata e três coroas de ouro, um delas singularizada no documento porque teria seis Alfas em torno, o que indica que estaria destinada para cada um dos três altares, correspondendo esta ao central, pairando sobre ele, como sabemos que se vinha fazendo desde a época dos visigodos. $^{207}$
\end{abstract}

No documento ainda constam duas cruzes, uma de ouro, que se encontra perdida, e outra que é a chamada Cruz de Fernando e Sancha, conservada no Museu Arqueológico Nacional de Madri. Uma cruz que possui o Cristo crucificado, algo que até então não era comum ("eburneam in similitudinem nostri Redemptoris Crucifixi"). Ainda são doados dois incensários de ouro, um grande de prata, cálice e pátena de ouro, diversas caixas de marfim

\footnotetext{
${ }^{204}$ YARZA LUACES, Joaquín. La ilustración del Beato de Fernando I y Sancha. In: WILLIAMS, John et al. Beato de Fernando I y Sancha. Barcelona: M. Moleiro, 2006, p. 66. Apesar de Yarza Luaces referir-se às encomendas de Fernando I como artes suntuárias e do livro, preferimos o termo "artefato", por frisar a ideia de dispositivo, um produto que exerce um trabalho, bem como a identificação de um objeto de cultura material, sem necessariamente resguardar as definições de arte atual. É problemático falar de um objeto de arte quando a designação pode ultrapassar a ideia de artefato medieval.

${ }^{205}$ Para Isidro Torviso a renovatio era um "processo de europeização", que levou as manifestações do estilo românico para a produção hispânica. Sobre o processo de renovação cultural sob o reinado de Fernando I, ver BANGO TORVISO, Isidro G., La piedad de los reyes Fernando I y Sancha. Un tesoro sagrado que testimonia el proceso de renovación de la cultura hispana del siglo XI. In: (coord.) Maravillas de la España medieval. Tesoro sagrado y monarquía, tomo I. Leão-Espanha: Junta de Castilla y León, 2001, p. 223-227. Sobre o intercâmbio cultural entre Espanha e outras localidades durante a Idade Média, ver, entre outros, o artigo de SILVEIRA, Aline Dias da. Europeização e/ou Africanização da Espanha Medieval: Diversidade e unidade cultural européia em debate. Revista de História, v. 28, n.2, p.645-658, 2009.

${ }^{206}$ No epitáfio de Fernando I é possível ler "Et fecit Ecclesiam hanc lapideam, quae olim fuerat lutea". Com a inscrição se indica que mandou substituir a pobre igreja de barro e ladrilho de Alfonso V por outra de pedra, a que então estava de pé. No epitáfio de Urraca, filha do casal real, diz que ela ampliou a igreja: "haec ampiavit Ecclesiam istam". YARZA LUACES, Joaquín. La ilustración del Beato de Fernando I y Sancha. In: WILLIAMS, John et al. Beato de Fernando I y Sancha. Barcelona: M. Moleiro, 2006, p. 66.
}

${ }^{207}$ YARZA LUACES, Joaquín. La ilustración del Beato de Fernando I y Sancha. In: WILLIAMS, John et al. Beato de Fernando I y Sancha. Barcelona: M. Moleiro, 2006, p.67, tradução nossa. 
enriquecidas com ouro ("et capsam eburneam operatam cum auro, et alias duas eburneas argento laboratas"), vasos de prata, telas preciosas, assim como doações de terra. No documento os reis rogam a Deus, com a intercessão de São João Batista, São Pelágio e Santo Isidoro, para que sejam aceitas essas doações comedidas ("numera exigua"). ${ }^{208}$ Os objetos e o documento de doação, "Instrumenta. Ad insigne Sancti Isidori. Monasterium Legionense pertinentia", ${ }^{209}$ mostram, além do emprego de materiais de alto custo econômico, que mesmo com a chegada de novas formas plásticas, já utilizadas na produção carolíngia e românica, os artefatos de Leão e Castela mantinham traços importantes da época visigoda e da produção moçárabe. ${ }^{210}$ Seria a Arca das Bem Aventuranças, segundo Yarza Luaces, um objeto que mostra claramente a

[...] interrelação entre motivos iconográficos ou modelos compositivos que procedem da Alta Idade Média hispânica e seguem em uso com o conhecimento e abertura ao otoniano, o que o torna anunciador do românico europeu. ${ }^{211}$

A aproximação entre os encargos de Fernando I e a produção otoniana ocorria, principalmente, segundo John Williams, por intermédio de Cluny. ${ }^{212} \mathrm{O}$ contato com Cluny foi iniciado, na verdade, pelo pai de Fernando I, Sancho III, o Maior (1004-1035), através de sua estreita relação pessoal com o abade de Cluny, Odilón (994-1049). A relação foi firmada por

\footnotetext{
${ }^{208}$ YARZA LUACES, Joaquín. La ilustración del Beato de Fernando I y Sancha. In: WILLIAMS, John et al. Beato de Fernando I y Sancha. Barcelona: M. Moleiro, 2006, p.67-68.

${ }^{209}$ Documento transcrito em RISCO, Manuel. España Sagrada. Madri: Biblioteca Pública de Segovia, 1787, tomo XXXVI, pp. CLXXXVIII-CXCII. Disponível <http://bibliotecadigital.jcyl.es/i18n/consulta/registro.cmd?id=4608>. Acesso em: 03 jun. 2014.

${ }^{210}$ BANGO, I (dir.). La piedad de los reyes Fernando y Sancha. Un tesoro sagrado que testimonia el proceso de renovación de la cultura hispana del siglo XI. In: (dir.) Maravillas de la España Medieval, Tesoro sagrado y monarquía. León, 2000, p. 223-228.

${ }^{211}$ YARZA LUACES, Joaquín. La ilustración del Beato de Fernando I y Sancha. In: WILLIAMS, John et al. Beato de Fernando I y Sancha. Barcelona: M. Moleiro, 2006, p.71, tradução nossa.

${ }^{212}$ A partir de um interessante estudo das imagens da Arca das Bem Aventuranças, Williams conclui que as cenas de Gênesis na Arca não são de tradição hispânica, mas indiretamente da Bíblia de Tours carolíngia, através de um modelo intermediário otoniano e que a figura do abade Hugo seria crucial para essa aproximação. WILLIAMS, John. Tours and medieval art of Spain. In: NORDENFALK, Carl A. J et al.Florilegium in honorem Carl Nordenfalk octogenarii contextum. Estocolmo: Nationalmuseum, 1987, p. 197-208. Outro estudo de Williams é referencial para essa questão WILLIAMS, John. Cluny and Spain. Gesta, XXVII/1 e 2 (1988), p. 93-101. Yarza Luaces também sugere a relação com a produção otoniana através de semelhanças entre o Sacramentário de Echternach (Darmstadt, Hessische landes-und Stochschulbibliothek, Cod, 1946, f. 18v), de 1030, com a imagem do f. 6, do Beatus de Facundus. YARZA LUACES, Joaquín. La ilustración del Beato de Fernando I y Sancha. In: WILLIAMS, John et al. Beato de Fernando I y Sancha. Barcelona: M. Moleiro, 2006, p. 86.
} 
Fernando $\mathrm{I}^{213}$ e o rei se comprometeu, sobretudo a partir de 1059 , a entregar anualmente um censo de mil dinares de ouro. ${ }^{214} \mathrm{O}$ valor dessa quantia provinha, majoritariamente, do regime de párias, tributos pagos pelas taifas muçulmanas aos reinos cristãos do Norte da península nos anos seguintes à desintegração do Califado de Córdoba, em 1031. ${ }^{215}$ As párias eram pagas de diversas formas, em moedas, metais preciosos, joalheria, têxteis e marfins. ${ }^{216} \mathrm{Na}$ política econômica de Fernando I esse regime permitiu levar à corte de Leão alguns dos melhores ourives do românico europeu. ${ }^{217}$ Os tributos geravam lucros para Cluny, para a renovação cultural em Leão e Castela, para o desenvolvimento político e econômico dos reinos cristãos espanhóis e financiavam, em parte, o avanço bélico durante o movimento de Reconquista.

Quanto ao meio religioso, o interesse de Fernando I por questões eclesiásticas serviu como

[...] motor a uma reforma, dentro da Igreja Leonesa, corporificada no Concílio de Coyanza (1055). Uma assembléia a que assistiram alguns abades e bispos das dioceses de Leão, Astorga, Lugo, Oviedo, Iria, Palência, Calahorra, Pamplona, Orense e Oporto, e que se centrou na recuperação da disciplina tradicional da Igreja, um valor que permitiu a posterior adaptação da renovadora corrente gregoriana. Aspectos como a consolidação da autoridade episcopal, as normas de administração dos sacramentos, ou as normas referentes à liturgia eucarística foram tratadas, entre outras disposições. ${ }^{218}$

A partir desse concílio, os reinos ibéricos tornaram-se sujeitos ao controle pontifício e a aproximação com Cluny permitiu uma expansão da regra beneditina como norma básica

${ }^{213}$ BISHKO, Ch. J. Fernando I y los orígenes de la alianza castellano-leobesa con Cluny. Cuadernos de Historia de España, XLVII-XLVIII, p. 35-135, 1968.

${ }^{214}$ PÉREZ, José Carlos Valle. Entre a continuidade alto-medieval e a renovação gótica: a arquitetura no Caminho de Santiago em Castela e Leão entre 1035 e 1230. In: GUINEA, Juan Carlos Elorza (dir.). Caminhos de Santiago: Arte no período românico em Castela e Leão, Espanha (séc. XI ao XIII) São Paulo: Junta de Castilla y León, Instituto Inclusartiz, 2007, p.56.

${ }^{215}$ As taifas localizavam-se em Al-Andalus, nome dado ao território ao sul da Península Ibérica conquistado pelos muçulmanos. Al-Andalus constituiu-se como emirado entre 756 e 929, e como califado entre 929 e 1031, posteriormente foi fragmentado em taifas, após um período de instabilidades e guerra civil que levou o califado de Córdoba ao colapso.

${ }^{216}$ Para maiores informações sobre as guerras de Reconquista e o regime de parias, ver o artigo de FLETCHER, Richard A. Reconquest and Crusade in Spain. Royal Historical Society, v. 37, série 5, p. 31-47, 1987. Disponível em: 〈http://roberthaug.files.wordpress.com/2013/08/fletcher-reconquest-and-crusade-in-spain.pdf>. Acesso em: 20 mar 2014.

${ }^{217}$ YARZA LUACES, Joaquín. La ilustración del Beato de Fernando I y Sancha. In: WILLIAMS, John et al. Beato de Fernando I y Sancha. Barcelona: M. Moleiro, 2006, p. 66.

218 SEVILLA-QUIÑONES, Margarita Torres. Espacios y sociedad en león durante los siglos XI y XI. In: GUINEA, Miguel Ángel G.; GONZÁLEZ, José María Pérez. (ed.) Enciclopedia del Románico en Castilla y León. Santander: Fundación Santa Maria la Real. Centro de Estudios del Románico, 2002, v 3, p. 23, tradução nossa. 
reguladora da vida monástica. Expansão que, no reinado de Afonso VI, contribuiu para a substituição do rito moçárabe pelo francês e o consequente início do desaparecimento das regras visigóticas anteriores, as quais regiam o ambiente monástico hispânico. ${ }^{219}$ As doações de Fernando I, e depois de seu filho Afonso VI, foram de crucial peso para a transformação da abadia de Cluny em um dos conjuntos arquitetônicos mais importantes da Europa românica. O investimento era tamanho que, em 1077, Afonso VI dobrou a quantidade de párias pagas pelos reis de taifas para poder cobrir os gastos com as encomendas artísticas. No reinado de Afonso VI, os monges beneditinos tornaram-se protagonistas das mudanças, situados à frente das principais comunidades do reino ocupavam importantes cargos da Igreja. ${ }^{220}$

Cluny foi o principal ponto de intercâmbios artístico e cultural que possibilitou a Fernando I expressar suas pretensões imperiais no imitar de práticas carolíngias e otonianas, como na encomenda de códices luxuosos. Desde o século X, códices especialmente luxuosos eram iluminados, na Europa ocidental, para os sucessores de Carlos Magno e, na Alemanha, para monarcas da dinastia otoniana.

Além do Beatus de Facundus, faziam parte dos códices encomendados o Diurnal ou "Livro de Horas de Fernando I"; ${ }^{221}$ o Liber Canticorum et Horarum, livro de orações em latim, copiado quatro anos depois do Diurnal, em 1059; ${ }^{222}$ uma cópia das Etimologias (Monasterio de El Escorial, Ms.\&.I.3), datada de 1047 e dedicada a Sancho II, o príncipe. ${ }^{223}$

\footnotetext{
219 Ver GARCía GALlO, Alfonso. El Concilio de Coyanza. Contribución al estudio del Derecho canónico español en la Alta Edad Media. A.H.D.E., v. XIX-XX, p. 257-633, 1951.

${ }^{220}$ Como referência sobre a relação entre Cluny e Fernando I ver BISCHKO, Charles J. Fernando I y Cluny CHE, XLVII-XLVIII, 1968, p. 31-135 e XLIX-L, 1969, p. 50-156.

${ }^{221}$ O Diurnal é um livro de orações particular, um Saltério litúrgico acrescido de Cânticos, de pequenos textos de Floro, Jerônimo e Alcuíno e de orações para a noite. Um saltério contém essencialmente o livro dos Salmos (150 Salmos do Antigo Testamento que compunham o hinário de Israel, destinado às sinagogas e templos israelitas). Muitas vezes relaciona-se com a prática devocional cristã para ser usado, por exemplo, nos mosteiros e conventos na recitação das Horas Canônicas desde as épocas em que o monarquismo foi estabelecido pelo Patriarca São Bento de Núrsia. Como exemplo mais conhecido tem-se o Saltério do Duque de Berry que contem orações para o dia, textos e os salmos. Além disso, os saltérios eram livros de comum propriedade aos leigos ricos e comumente usados para aprender a ler. O Diurnal de Fernando I e Sancha encontra-se atualmente na Biblioteca Universitária de Santiago de Compostela. Copiado por Pedro e iluminado por Frutuoso em 1055, este manuscrito conta com 300 fólios, com algumas imagens que ocupam uma página inteira, como o labirinto, onde se lê "Ferdinandi regis sum líber necnon et Sanciae reginae". Nas iniciais mesclam-se formas animais e vegetais, segundo a produção moçárabe.

222 O Liber Canticorum et Horarum encontra-se na Universidade de Salamanca (ms. 2668) e foi escrito por Christophorus, em 1059. Ele é formado por 187 fólios e apesar de não possuir miniaturas, há várias iniciais iluminadas com entrelaços e motivos zoomórficos.

${ }^{223}$ LUACES, Joaquín Yarza. La ilustración del Beato de Fernando I y Sancha. In: WILLIAMS, John et al. Beato de Fernando I y Sancha. Barcelona: M. Moleiro, 2006, p.72.
} 
Tanto no Diurnal quanto no livro de orações aparece o nome de Sancha ao lado de Fernando I, como dedicatória das obras. Segundo García, ${ }^{224}$ seria um indício da importância da figura da rainha no reinado de Fernando I. Em algumas ocasiões, Sancha assumia a responsabilidade frente a assuntos nada triviais, como a questão da sepultura de Fernando I. Ela o convenceu sobre a conveniência de ser sepultado em Santo Isidoro de Leão ao invés de eleger o monastério de Oña, devido à sua origem Navarra, ou o monastério de São Pedro de Arlanza, por ter herdado de seu pai, Sancho III, o condado de Castela, em 1035. Fernando I escolheu Leão como estratégia para expressar seu comprometimento e esforço de tornar Leão em um reino próspero. Um reino que não apenas herda as conquistas de Alfonso V, pai de Sancha, mas um reino aberto às correntes ideológicas e religiosas que vinham de regiões da atual França e Itália. Tradição e renovatio andavam lado a lado como um modo de amenizar a hostilidade inicial do povo leonês. ${ }^{225}$ Fernando I casou-se com Sancha após o assassinato de García Sánchez de Castela, o prometido de Sancha, supostamente a mando da família Vela. Como dote, Fernando I ganhou as terras compreendidas entre os rios Cea e Pisuerga e em 1035 tornou-se conde de Castela. As terras do dote eram poucas comparadas às conquistas que viriam.

Na Batalha de Tamarón, em 1037, Fernando I derrotou seu cunhado Bermudo III, que, sem descendentes, permitiu ao conde de Castela ser rei de Leão por direito de consorte, cinco anos após seu casamento com Sancha. Para o povo de Leão, a princípio, Fernando I era como um intruso navarro, criado em um ambiente distinto do castelhano e que havia matado o rei legítimo. O encargo de artefatos luxuosos pelo casal real e a menção de ambos os cônjuges nas dedicatórias mostra que o nome de Sancha apareceria também para sublinhar a estirpe leonesa das encomendas. Sua presença ganha um sentido de responsabilidade política muito afim ao de seu marido. Não só a rainha, mas também os encargos realizados pelo casal real, foram de grande importância como mediadores entre o rei proveniente de Navarra e o povo de Leão.

\footnotetext{
${ }^{224}$ RUIZ GARCÍA, Elisa. Arma regis: Los libros de Fernando I y doña Sancha. Lemir, n. 18, 2014, p. 149

${ }^{225}$ Segundo Yarza Luaces, esta hostilidade de certo não era generalizada, mas pode ser pensada através de registros que corroboram com essa visão, sobretudo aqueles que dizem respeito às relações de Fernando I com alguns membros da família Laínez. YARZA LUACES, Joaquín. La ilustración del Beato de Fernando I y Sancha. In: WILLIAMS, John et al. Beato de Fernando I y Sancha. Barcelona: M. Moleiro, 2006, p. 59-90. Para maiores detalhes, ver ESTEPA, C. Estructura social de la Ciudad de León (siglos XI-XIII). Leão, 1977.
} 
Mediante o paralelismo entre as atividades políticas de exercício do poder e as encomendas de objetos suntuosos por Fernando I, concordamos com García na escolha da palavra arma por um uso metafórico,

[...] para designar esse recurso ou instrumento (arma) complementares do que dispõe o rei durante seu mandato para atribuir valor, através da munificência régia, a certos aspectos de sua execução, tais como a intersecção ideológica com a monarquia goda ou Ordo gothorum, a legitimidade de seu acesso ao trono e sua religiosidade. Fernando, como Alfonso II o Casto, quis recriar em Leão a corte toledana. O tipo de monarca ideal significava na época o alcance de êxitos políticos pela via da guerra unidos a uma concepção cristã da existência. A obrigação era ser um rex bellator, mas também rex pius. ${ }^{26}$

As encomendas do rei Fernando I mostravam-se como um discurso com efeitos políticos e a conservação de quatro manuscritos era um feito notável, com precedência apenas de Alfonso III. ${ }^{227} \mathrm{O}$ trabalho de Fernando I tornou a cidade de Leão um dos maiores centros de mecenato por onde passariam os peregrinos a caminho do santuário de Santiago de Compostela. $^{228}$ Não apenas a cidade, mas as obras que nela se ostentavam, transformava-se em um símbolo de poder e riqueza.

O Beatus de Facundus foi uma criação relacionada ao fortalecimento e legitimação do governo de Fernando I, principalmente pela menção a Sancha ao lado do rei $^{229}$ e pelo processo de renovatio. Uma renovação assinalada na permanência de heranças alto medievais e presença de traços formais oriundas de além Pirineus, e na renovatio, favorecida pelo uso de ornamentos vindos de outras culturas, com uma carga potencial de memória imperial.

\footnotetext{
${ }^{226}$ RUIZ GARCÍA, Elisa. Arma regis: Los libros de Fernando I y doña Sancha. Lemir, n. 18, 2014, p. 140, tradução nossa.

${ }^{227}$ YARZA LUACES, Joaquín. La ilustración del Beato de Fernando I y Sancha. In: WILLIAMS, John et al. Beato de Fernando I y Sancha. Barcelona: M. Moleiro, 2006, p. 77.

${ }^{228} \mathrm{O}$ sepulcro do apóstolo Santiago foi descoberto provavelmente entre os anos 820-830, durante o reinado de Afonso II. A cidade de Compostela tornou-se um importante destino de peregrinação e o Caminho acolheu muitas obras que sofreram a difusão de novos programas iconográficos e estilísticos. Sobre as relações entre os Caminhos de Santiago e a produção artística em Leão e Castela, ver GUINEA, Juan Carlos Elorza (dir.). Caminhos de Santiago: Arte no período românico em Castela e Leão, Espanha (séc. XI ao XIII) São Paulo: Junta de Castilla y León, Instituto Inclusartiz, 2007. Material produzido a partir da exposição homônima na Estação Pinacoteca, São Paulo, entre março e maio de 2007.

${ }^{229}$ Vale ressaltar que as tábuas genealógicas presentes no Beatus de Facundus também podem ser alusivas a um conceito de linhagem e legitimidade.
} 
Como parte de um tesouro real, o Beatus de Facundus assumia outros papéis além das funções teológica e litúrgica comuns a um Comentário ao Apocalipse. ${ }^{230}$ De acordo com o historiador francês Éric Palazzo, depois das relíquias, os livros são os objetos de tesouro mais representativos da memoria.

\begin{abstract}
Ao lado de todos esses livros destinados ao culto, 'utilitários', presentes em um monastério, ou, mais geralmente em uma igreja, os livros (especialmente litúrgicos) do tesouro fazem figura de 'relíquias' no sentido de que eles não têm uma função 'prática', mas essencialmente 'memorial. ${ }^{231}$
\end{abstract}

Ou seja, a função de memória destes objetos luxuosos se sobressai a suas funções litúrgicas e sua materialidade conjugar-se-ia com os valores teológicos e políticos no desenvolvimento e perpetuação da memória espiritual de um lugar ou de uma pessoa.

Para Yarza Luaces, ${ }^{232}$ a data de encomenda do Beatus não era casual. Alfonso III encomendou a Cruz da Vitória em 908 para doá-la à igreja de São Salvador, em Oviedo, exatamente cem anos depois de Alfonso II ter doado a Cruz dos anjos como relíquia a esta mesma igreja. E em 1047 completavam-se dez anos desde que Fernando I fora coroado na catedral de Leão, após a morte de seu cunhado em campo de batalha. ${ }^{233}$ Podemos pensar no manuscrito como um objeto de comemoração à sua conquista, ao seu triunfo como rei, sendo o Beatus um manuscrito apropriado à ocasião, por conter a temática da vitória maior, a do Bem contra o Mal, expressa no Apocalipse. Desde a sua encomenda, o códice permaneceu na

\footnotetext{
${ }^{230}$ Segundo uma normativa do cânone XVII do IV Concílio de Toledo, realizado em 633, a leitura do Livro do Apocalipse seria obrigatória entre a Páscoa e Pentecostes. Outros cânones conciliares da época visigoda também incluíam a leitura do Apocalipse na liturgia hispânica. Tais normativas são motivos suficientes para Alberto del Campo Hernández afirmar o Beatus como objeto destinado a ideia de praedicare (leitura e homilia), um objeto de apoio aos pregadores,que então tinham um período minimamente definido para sua leitura. CAMPO HERNÁNDEZ, Alberto del; FREEMAN, Leslie G.; GONZÁLEZ ECHEGARAY, Joaquín (ed.). Beato de Liébana. Obras completas y complementarias. Edição bilíngue do latim ao castelhano. Madrid: Biblioteca de Autores Cristianos, 2004, v. 1, p. 25-26. Embora a prática de leitura do Apocalipse não fosse exclusiva para a Península, as normativas mostram que os fies da Hispânia teriam ouvido a lectio do Apocalipse no ciclo Pascal, ao invés do Antigo Testamento, mesmo antes da aprovação oficial do rito romano no final do século XI. ESCOLAR, Hipólito. Los manuscritos: historia ilustrada del libro español. Madrid: Fundación Germán Sánchez Ruipérez, 1996, p. 101. Sobre os cânones conciliares, ver VIVES, José (Ed.). Concilios Visigóticos e Hispanoromanos. Madrid-Barcelona: Consejo superior de investigaciones científicas. Instituto Enrique Flóres, 1963.
}

${ }^{231}$ PALAZZO, Éric. Le livre dans les trésors du Moyen Âge. Contribution à l'histoire de la Memoria médiévale. Annales. Histoire, Sciences Sociales. 52e année, n. 1, p. 93-118, 1997, p. 116, tradução nossa.

${ }^{232}$ YARZA LUACES, Joaquín. La ilustración del Beato de Fernando I y Sancha. In: WILLIAMS, John et al. Beato de Fernando I y Sancha. Barcelona: M. Moleiro, 2006, p. 78.

${ }^{233}$ YARZA LUACES, Joaquín. La ilustración del Beato de Fernando I y Sancha. In: WILLIAMS, John et al. Beato de Fernando I y Sancha. Barcelona: M. Moleiro, 2006, p. 78. 
biblioteca de Santo Isidoro de Leão até 1572, quando Ambrosio de Morales tomou conhecimento de sua existência. $^{234}$

Celebrar o comprometimento de Fernando I com o reino de Leão, celebrar as conquistas territoriais e econômicas das campanhas militares, ${ }^{235}$ celebrar e pedir proteção durante a espera até o momento da salvação. ${ }^{236}$ Livro litúrgico, de leitura monástica, para iluminação espiritual ou como objeto de doação, o Beatus de Facundus atendia aos interesses políticos e sociais do rei Fernando I, ${ }^{237}$ aquele que tinha o importante papel de prosseguir com as estratégias de renovações ideológico-político-culturais, iniciadas por seu pai, Sancho III o Maior.

${ }^{234}$ MORALES, Ambrosio de. Crónica general de España, Tomo VII. Madri: edição da oficina de Don Benito
Cano, 1791; ver também FLÓREZ, Henrique (ed.). Viage de Ambrosio de Morales por orden del rey D.
Felipe II a los reinos de León y Galicia y principado de Asturias para reconocer las reliquias de santos,
sepulcros reales y libros manuscritos de las catedrales y monasterios. Madri: Antonio Martin, 1765. Nas
palavras de Morales, "Otro libro destos está en la insigne librería del Real Monasterio de Santo Isidoro de León.
Fue el libro, a lo que yo creo, del rey don Fernando el primero, o que él lo mandó escribir, según al principio se
da en alguna manera a entender. Y parece bien ser joya de rey, por las muchas y grandes iluminaciones que tiene
de mucho oro y pintura, con algún acertamiento en ella, así que no parece de aquellos tiempos tan antiguos
[...]." SÁNCHEZ MARIANA, Manuel. La tradición de los Beatos y el Beato de Fernando I y Sancha. In:
WILLIAMS, John et al. Beato de Fernando I y Sancha. Barcelona: M. Moleiro, 2006. p. 42 .
${ }^{235}$ As campanhas militares empregadas por Fernando I concentraram-se após a morte de seu irmão, García III,
em 1054, na Batalha de Atapuerca. As campanhas vitoriosas de Fernando I não se limitavam ao âmbito religioso,
pois, ao mesmo tempo, significavam a retomada de um território como máquina econômica, geradora de tributos,
como as párias. ${ }^{236}$ No prefácio geral da obra, quando Beato de Liébana faz a dedicatória a Etério, expõe o ambiente monástico a que sua compilação estava sujeita: "Tudo isso segue, santo padre Etério, a seu pedido, para a edificação do zelo dos irmãos, tenho dedicado a você, de maneira que farei também co-herdeiro do meu trabalho aquele de cuja companhia gozo como religioso.”. CAMPO HERNÁNDEZ, Alberto del; FREEMAN, Leslie G.; GONZÁLEZ ECHEGARAY, Joaquín (ed.). Beato de Liébana. Obras completas y complementarias. Edição bilíngue do latim ao castelhano. Madrid: Biblioteca de Autores Cristianos, 2004, v. 1, p. 33. Apesar de o manuscrito ser compilado por um monge e que poderia servir de material para homilia e contribuir com a edificação dos irmãos, fossem eles monges ou laicos, não é possível afirmar que todas as cópias possuíssem uma única função e que esta estaria necessariamente relacionada ao ambiente monástico. John Williams apoia sua pesquisa sobre os usos monásticos dos Beati em rubricas pós-medievais presentes nos Beati de Lorvão (1189) e de Las Huelgas (1220), do século XV e XVII, respectivamente. Para relacionar a obra fora desse ambiente, Williams baseia seus argumentos em glosas encontradas no Beatus de Navarra (final do séc. XII), provavelmente do século XIII, e no Beatus de Morgan (c.940-945), do século XIV ou XV. Estes estudos contribuem para o entendimento de que a atualização dos usos segue o contexto da cópia. No caso do Beatus de Facundus, dentro das possibilidades de usos, é certo que frequentemente os Beati tenham servido como exercício devocional privado. "A leitura pessoal do Comentário com o objetivo de iluminação espiritual seria uma prática especialmente apropriada, de fato tradicional, para a vida contemplativa". WILLIAMS, John. The illustrated Beatus: a corpus of the illustrations of the Commentary on the Apocalypse. London: Harvey Miller, 1994, v. 1, p. 113 A exemplo das rubricas nos Beati de Lorvão e de Las Huelvas, pode-se pensar que essa leitura privada tenha se concentrado na época da Páscoa.

${ }^{237}$ A dinâmica de dom e contra-dom é uma prática fundamental na manutenção da ordem social no medievo, afirma Lauwers. Por um lado, a doação (dom) de bens por parte da nobreza legitima sua autoridade na manutenção da memória, de um poder legado dos ancestrais aos herdeiros. Por outro lado, o clero se reafirma como "intermediário autorizado" entre a ordem material e a espiritual. Contudo, o contra-dom, não seria, para Lauwers, uma obrigação de devolução de um bem celeste em troca de um bem material. Ver, dentre outros, LAUWERS, Michel. Le cimetière dans le Moyen Age latin: Lieu sacré, saint et religieux. Annales. Histoire, Sciences Sociales, 54e Année, No. 5, Sep. - Oct., 1999, pp. 1047- 1072. 
Diante do estudo da imagem do f.7 (labirinto) e dos diálogos do manuscrito com suas imagens e com o contexto ao qual pertencia, o Beatus de Facundus assume, ele também, uma função ornamental na Hispânia do século XI.

\begin{abstract}
A ornamentalidade é entendida aqui antes de tudo como um modo de tratamento estético da imagem. Sua primeira função é a celebração, independente da capacidade dos motivos ornamentais assumirem outras funções (simbólicas, mágicas, rituais..... ${ }^{238}$
\end{abstract}

A dimensão estética do ornamental celebra a imagem e altera seu status, consequentemente, altera o status do objeto, do detentor e de todas as questões que envolvem a posse e a encomenda de um Beatus. Antes o manuscrito celebra, para então trabalhar junto de suas imagens como símbolo real e memória de um tesouro. Na imagem do labirinto (f.7), destacamos como o trabalho dos entrelaços, a acuidade com que são feitos, o ritmo que criam na imagem entre os componentes materiais e contextuais são importantes para conferir um valor ornamental à obra (e à memória dos doadores). Nos próximos capítulos, o ornamental deixa a linha da costura dos entrelaços e outros ornamentos de materialidade já reconhecidos pela História da Arte, os padrões de elementos figurativos, para embrenhar-se em outro campo de atuação, nas cores.

${ }^{238}$ BONNE, Jean-Claude. De l'ornement à l'ornementalité: La mosaïque absidiale de San Clement de Rome. Actes du Colloque International: Le rôle de l'ornement dans la peinture murale du Moyen Âge. Saint-Lizier, 1-4 juin 1995. Poitiers: Université de Poitiers, 1997, p. 103. 


\section{UMA SUTIL ECONOMIA DAS CORES}

Quando Jérôme Baschet delegou à imagem um corpo, um gesto, uma vida, como imagem-objeto, permitiu-nos adentrar em objetos que antes eram comumente vistos de modo fragmentário. Uma imagem do Beatus de Facundus não pode mais ser "vista", e assim o queremos, senão dentro do manuscrito, junta de seus pares, como parte de outros Beati, dentro do reinado de Fernando I e como parte daquilo que ela clama para si. Como seria possível pensar em uma imagem do manuscrito apenas com um olhar voltado para seu contorno, para sua forma e narrativa, se sabemos que em outro lugar ela continua a falar. Entre a storia e a explanatio, a imagem reclama ser reconhecida em seu lugar e em sua matéria. Ela demanda que não sejamos ludibriados por seu poder iconográfico. Chamá-la de ilustração é ofensivo e limitante. A imagem também exige que nós não nos percamos nas artimanhas da beleza decorativa, porque só assim, quando sentido e beleza dialogam com o entorno da imagem, é que podemos ver suas engrenagens funcionar.

E parece mesmo que o ornamental é uma corrente que faz girar as roldanas dessa engrenagem imagética medieval. Entendemos aqui o termo do modo operacionalizado por Jean-Claude Bonne, como um modus operandi, e não um motivo formal de ornamentação dependente única e exclusivamente de sua forma para ocupar um posto decorativo, no sentido mais estrito, e de preenchimento de uma superfície. ${ }^{239}$ Quando Bonne cunhou o termo ornamental (e ornamentalidade), ele não apenas permitiu que o ornamento fosse funcional, e que readquirisse sua amplitude de ornamentum, como também nos permitiu entrar em uma catedral e sentir o barulho das engrenagens da imagem, mesmo de olhos fechados, pelo calor das cores irradiadas de um vitral.

O poder do ornamental não se restringe à forma, a um objeto específico, mas tem a propriedade de atravessar a imagem, quer dizer, trabalhar dentro e através dela. Entrelaços, elementos geométricos, vegetais, camafeus, pedras preciosas, arabescos, estrelas, montanhas, cruzes, todo tipo de padrão formal repetido sobre uma superfície pode ser ornamento. $\mathrm{O}$ ornamento pode operar ao lado da figuração, ou ser ele mesmo figurativo, mas sem que se

\footnotetext{
${ }^{239}$ BONNE, Jean-Claude. De l'ornemental dans l'art médiéval (VIIè - XIIè siècle): Le modele insulaire. In: SCHMITT, Jean-Claude; BASCHET, Jérôme (orgs). L'image: Fonctions et usages des images dans l'Occident médiéval. Paris: Le Léopard d'Or, 1996, p. 213.
} 
deixe reduzir a um sentido ou símbolo. Ele, antes de tudo, irá ornar, honrar e celebrar a imagem. Criam-se tensões entre ornamento e representação

Formal, o ornamental o é manifestamente, sobretudo, quando toma um caráter claramente "abstrato" que exclui ou suspende a ideia de signo - como em um tapete de entrelaços ou qualquer outra composição de motivos mais ou menos geométricos - mas sem se tornar, necessariamente, para tanto, um sistema de determinações fechado sobre ele mesmo. E figurativo ou abstrato, o ornamental não se deixa, não mais, reduzir-se ao signo ou ao símbolo que ele coloca em obra de um modo manifesto ou discreto, mas ornando, precisamente, ele transborda e desfoca - como a cruz com a qual certas formas de arte medieval jogaram ao infinito a ponto de apagar as conotações religiosas, ou melhor, de deslocá-las do plano da representação àquele da prática. Como o mito, com o qual ele guarda afinidades, o ornamental pode operar sobre (ou com) os signos sem ser fundamentalmente da ordem do signo ou da representação. Mas funciona também em tensão com eles, pois representação e ornamentação não cessam de se confrontar e mesmo de se atravessar um ao outro. $^{240}$

O ornamento é uma ferramenta estética da imagem, que a celebra antes de assumir outras funções em tensão ou não com a representação. $O$ ornamento se comporta de modo transversal, ${ }^{241}$ imiscui-se por todos os cantos da imagem e do objeto que orna. Pela transversalidade, outros elementos, como as cores, podem assumir o trabalho de ornamento. As cores portam-se, nas imagens medievais, segundo o mesmo modus operandi que outros ornamentos mais figurativos ou representacionais. É no estudo das cores como ornamento que os termos ornamental e ornamentalidade, de Bonne, são mais solidários. Eles abrangem elementos que jamais estariam nos catálogos de padrões ornamentais, como o de Owen Jones, assim como conferem um comportamento de ornamento (ornamentalidade) a tudo aquilo que segue a mesma lógica de funcionamento: celebrar e trabalhar. ${ }^{242}$

\footnotetext{
${ }^{240}$ BONNE, Jean-Claude. De l'ornemental dans l'art médiéval (VIIè - XIIè siècle): Le modele insulaire. In: SCHMITT, Jean-Claude; BASCHET, Jérôme (orgs). L'image: Fonctions et usages des images dans l'Occident médiéval. Paris: Le Léopard d'Or, 1996, p. 208-209, tradução nossa.
}

${ }^{241}$ BONNE, Jean-Claude. De l'ornemental dans l'art médiéval (VIIè - XIIè siècle): Le modele insulaire. In: SCHMITT, Jean-Claude; BASCHET, Jérôme (orgs). L'image: Fonctions et usages des images dans l'Occident médiéval. Paris: Le Léopard d'Or, 1996, p.209. Em nosso trabalho não seguimos as diferenciações classificatórias entre ornamento e ornamental, como Bonne o faz nas citações que utilizamos e, sobretudo, na ideia de transversalidade. Sobre essa questão, ver nota 158.

${ }^{242}$ Essa noção é importante também na medida em que frisa uma multiplicidade de ornamentos, pois pela transversalidade, tudo pode ser ornamental, a exigir que se faça a adequada diferenciação de que "tipo" de ornamento se fala. Quando lidamos com as cores como ornamento, no caso do Beatus de Facundus, falamos de cores em um objeto medieval, o que em muito se diferencia se levarmos as mesmas cores, até mesmo a reprodução dessas imagens, para dentro de uma galeria de arte (desdobrada em obra contemporânea) ou para uma ornamentação mais decorativa, em uma sala de estar doméstica. Aqueles que utilizam post-its (blocos adesivos) devem se perguntar se a escolha do papel colorido é para uma diferenciação temática entre cada observação ou se a cor empresta sua ornamentalidade de um modo muito mais evidente do que se pensaria. Para tirar a dúvida, se sua parede de infinitos papeizinhos coloridos não assume um papel de ornamento, observe se 
As cores agem de modo ornamental, elas celebram a imagem, o manuscrito, o reino, o objeto histórico, ${ }^{243}$ e se colocam à disposição da engrenagem para exercerem outras funções que não a de preenchimento. A ideia de Bonne, de que a imagem medieval usa a cor como modo de celebração, pode ser pensada em analogia ao nosso fascínio com os fogos de artifícios, principalmente no réveillon. Eles são os ornamentos que mais evidenciam a função celebrativa através de suas propriedades estéticas. Pelas cores, pelo efeito sonoro e do movimento (explosão de cores e sons) comemoramos, no réveillon, a esperança e expectativa de um novo ano, do futuro, ao mesmo tempo em que retornamos à lembrança o ano que terminou. Celebrar é dizer "isto é importante e deve ser acolhido com solenidade".

Apesar de compreendermos razoavelmente bem essa relação celebrativa, de honra, o estudo sobre as funções assumidas pela cor-ornamento guarda a complexidade que é própria do estudo de um fenômeno cultural. A cor tem sua vivência e significações segundo as determinações de época e sociedade em que é empregada. ${ }^{244}$ Não há nada de universal na cor, nem em sua natureza, nem em sua percepção. Sua complexidade impossibilita o estudo da cor apenas de acordo com leis das ciências ditas naturais, bem como em sua redução a simbologias imutáveis. Cada campo de estudo dedica-se à cor segundo suas "necessidades e leis", por assim dizer. Se, no âmbito do senso comum, herdamos alguns significados simbólicos das cores que usamos com frequência, como no valor que damos ao ouro, em um estudo teórico, essa herança é uma pequena parcela que diz que também fazemos parte dessa construção histórica, mas que esse conhecimento mais nos afasta que aproxima da imagem medieval. Nem sempre percebemos essa mutabilidade com tanta clareza quanto gostaríamos, tampouco temos a dimensão "real" da amplitude dessa noção nos modos de vivência do mundo que é cor. ${ }^{245}$

todos os papeis ainda funcionam como lembrete ou anotação e tente descartar aqueles que já cumpriram sua função. Sentirá saudade.

${ }^{243}$ Não podemos esquecer que o manuscrito tem vida própria e que ele também sofre com a mudança temporal, não apenas em sua degradação material, como no seu sentido de objeto de museu, ou biblioteca, nesse caso.

${ }^{244}$ PASTOUREAU, Michel; SIMONNET, Dominique. Breve historia de los colores. Barcelona: Paidós Ibérica, 2006.

${ }^{245}$ Quando o trabalho de pesquisa é pensado como um work in progress, afetamos não apenas a extensão temporal do trabalho, que continua a acontecer enquanto produz "frutos", mas também mostra que o trabalho não pode se enrijecer em um mundo que não se enrijece. Nossas construções, por mais que se estendam para objetos produzidos no passado, elas partem do presente e contaminam o presente do pesquisador. A vivência está sujeita ao conhecimento, as aquisições voluntárias e involuntárias para se vivenciar o mundo, que pode até estar no presente, aquele da ação, mas não se localiza dentro de uma pequena realidade estanque. Por mais que nem sempre estejamos atentos ao modo como uma pesquisa atinge o pesquisador, não podemos ignorar a contaminação desses mundos. Nesse sentido, posso dizer que parte da pesquisa sobre a cor no Beatus de Facundus foi atingida pelas concepções de cor da minha avó. Observe que aqui utilizo o verbo na primeira 
Em meio a essa complexidade, como poderíamos nos aproximar do emprego do uso das cores como ornamento no Beatus de Facundus? Certamente não podemos nos valer unicamente da nossa concepção moderna de cor para compreender a cor medieval. Não conseguimos negar as heranças das experiências newtonianas com prismas na descoberta dos espectros de cor, ${ }^{246}$ mas podemos retirar dessas construções um parâmetro para estabelecermos conexões com os sistemas cromáticos medievais. Desse parâmetro podemos recorrer apenas aos três conceitos que formam o modelo newtoniano de cor - matiz, valor e saturação - com consciência de que, na produção medieval, essas propriedades comportam-se de modo diferente. O matiz é o estado puro da cor, sem aderência de branco ou preto, é o nome da cor (por exemplo, vermelho). O valor, que também pode ser chamado de brilho, refere-se ao grau de branco ou preto que é adicionado ao matiz. Quanto maior a concentração de preto no matiz, diz-se que o valor é baixo, diferente da adição de branco, em que a cor se intensifica em claridade e tem valores mais altos. Já a saturação diz da intensidade de pureza de uma cor, e por isso, às vezes, é chamada mesmo de intensidade. Quando falamos de uma cor pura em matiz, falamos de uma cor completamente saturada. Para nossa concepção contemporânea de cor, o matiz seria o primeiro passo de diferenciação e organização das cores em um círculo cromático. ${ }^{247}$

pessoa do singular, porque é uma contribuição estritamente pessoal, porque aqui a minha avó, por mais que tenha contribuído, não raciocina comigo, não posso dizer "pensamos". O uso do verbo na primeira pessoa do plural não é um "plural de modéstia", mas um "plural justo", em que reconhecemos a contribuição de todos para o trabalho, em que "todos" são aqueles que dialogaram sobre o trabalho e aqueles que desconhecem a contribuição, como minha avó. Um evento em específico me ajudou a compreender que não podemos observar as cores segundo nossos juízos, ela precisa ser pensada como construção cultural. Em uma manhã, minha avó me perguntou por que eu estava de roupa preta. Abaixei os olhos e me observei. Respondi "Não sei, vó, só coloquei". Ela não ficou satisfeita com a resposta e insistiu: "É para um enterro ou para ficar elegante?". Eu sorri e achei melhor escolher a segunda opção. Minha avó apenas balançou a cabeça em confirmação e saiu do meu quarto. Achei que ela já havia se desligado do assunto, enquanto eu me prendi na observação da quantidade de blusas pretas e azuis que eu tenho em meu armário e que me levaram a uma escolha inadequada para um dia de verão. Pouco depois ela voltou com uma roupa retirada do varal e disse: "Toma, essa é mais alegre". E foi assim que comecei a repensar minha estação do ano. Segundo minha avó, amarelo e temas ornamentais são mais alegres que uma cor preta, esta deve ser destinada ao luto e à elegância de vestuário. Fiquei com isso em mente, como pode uma pessoa que não reconhece mais a neta e a filha, por ter Alzheimer, que paquera meu avô sem saber que ele é seu marido, que perde aos poucos suas referências, ter de forma tão nítida essa memória involuntária de significados e sensações das cores? Esse evento, assim como muitos que acontecem nas vivências de outros pesquisadores, foi um importante reafirmador da cor como fenômeno social e cultural, como frisa Michel Pastoureau em seus esforços para trilhar uma história das cores, de sua construção social.

${ }^{246}$ Como livro referencial ao campo da História da Arte para se pensar a cor opticamente, ver PEDROSA, Israel. Da cor a cor inexistente. 10 ed. São Paulo: Senac São Paulo, 2009.

${ }^{247}$ Existem vários modelos de círculo cromático, que, de modo geral, ordenam as cores em um círculo de acordo com sua matiz (tom) e a geração de outras matizes por misturas. Nessa organização é possível localizar as cores primárias, secundárias, terciárias, complementares e outras relações entre as cores segundo uma questão de percepção óptica. 
Contudo, para o medievo, faz-se crer que o valor é o principal elemento de organização dos sistemas de cor. ${ }^{248}$ Os matizes se distribuem ao longo de um modelo linear, e não circular, como é hoje. Na escala medieval, um dos extremos da linha seria ocupado pela cor preta e o outro, pela cor branca. Próximo ao polo preto haveria cores como o azul e o roxo, e nas proximidades do branco, o vermelho e o amarelo. Esse entendimento é crucial para que na observação de uma cor no Beatus de Facundus não sejamos, como dito, ludibriados pela vontade da significação. $\mathrm{O}$ vermelho pode doar seu valor para expor-se como fonte de claridade, em uma representação do sol, por exemplo, mas pode também ter uma função e uma existência (por que foi utilizado) que se justifica apenas em conjunto com outros elementos da imagem.

Segundo Pastoureau “[...] Uma cor nunca vem só; não encontra sua razão de ser, não adquire o seu significado até que a associe e a oponha a uma ou mais cores diferentes". ${ }^{249}$ Significa que a cor é somente quando outros elementos dialogam com ela. O azul do céu, o azul do mar, o azul da água (que é transparente), o azul do menino (que não existe sem o rosa da menina - e em breve nenhum dos dois existirá), ${ }^{250}$ cores que só posso dizer e serem entendidas, visualizadas, porque fazemos associações. Associações que precisam ser semelhantes entre as que eu faço quando escrevo sobre o azul e as que o leitor faz quando lê sobre o azul do qual falo, do contrário, não haveria um entendimento das diferenciações. Se pensarmos em relação ao mundo natural, o azul pode ser sinônimo de luz, pela observação do céu, e indiretamente pode remeter-se ao sagrado, mas ao mesmo tempo, pode compor o corpo de um demônio ou outro ser sombrio, a exemplo da imagem do f.135 do Beatus de Facundus,

${ }^{248}$ GAGE, John. Color and Culture: Practice and Meaning from Antiquity to Abstraction. Califórnia: University of California Press, 1999, p. 70.

${ }^{249}$ PASTOUREAU, Michel. Una historia simbólica de la Edad Media occidental. Buenos Aires: Katz, 2006, p.130, tradução nossa.

${ }^{250}$ Em Pink and Blue: Telling the Girls From the Boys in America, Jo B. Paoletti nos mostra a relação entre cores e gêneros surgiu apenas no começo do século XX, originada de estratégias publicitárias para venda de roupas. De início, ao contrário do que encontramos majoritariamente hoje, o mercado produzia e indicava roupas rosa para meninos e azuis para meninas. De acordo com os relatórios e propagandas das primeiras décadas do século XX, o rosa e o vermelho eram indicados para meninos por serem cores "intensas e decididas" e os tons de azul aconselhados para meninas por ser mais "delicado e amável". Some-se a isso a relação do rosa e do vermelho com as cores das fardas militares inglesas e do azul com o manto de Nossa Senhora. Durante o correr do século XX essa situação modificou-se de maneira distinta em muitos países. Embora as razões para que a representação de gênero dessas cores tenha se invertido fortemente na década de 1980 sejam extremamente variáveis de acordo com a localização, é bastante provável que tal mudança relaciona-se com os avanços das tecnologias de comunicação e, novamente, com objetivos mercadológicos. PAOLETTI, Jo Barraclough. Pink and Blue: Telling the Girls From the Boys in America. Indiana, USA : Indiana University Press, 2012. 
na qual Hades é monocromaticamente azul. ${ }^{251}$ As cores são construções históricas e não podem ser dissociadas dessa carga.

Para Bolman, a escolha por uma cor em detrimento de outra, nos Beati, pode ser guiada por quatro diferentes referências: iconográfica, mundo natural, simbolismo e apreciação estética da variedade. ${ }^{252}$

Como referência iconográfica, a presença da cor explica-se por uma estreita correspondência com o texto. Podemos dizer que esse é o principal motivo para as imagens ocuparem, por tanto tempo, o cargo de ilustradoras do texto, a seguir as coordenadas textuais de modo subordinado. É certo que, quando falamos de uma imagem medieval, mesmo quando ela tem uma amarra que faz as engrenagens girarem todas ordenadas num só sentido e em apenas um ritmo, como manda o manual que a explica, ela, ainda assim, consegue subverter essa relação de descendência. Como aponta Bolman, no texto do Comentário ao Apocalipse, há quatro passagens da storia que indicam a presença de nuvens na narrativa da imagem que as segue: Ap 1, 7; Ap 10,1; Ap 11, 12 e Ap 14, 14. ${ }^{253}$ A essas passagens relacionam-se, no Beatus de Facundus, as imagens de ff 43v, 176v-177, ${ }^{254} 182 \mathrm{v}$ e 209, respectivamente (Figura 22). Apenas no Apocalipse 14, a indicação é acompanhada de uma descrição da cor da nuvem: nubem albam. ${ }^{255}$ A figuração das nuvens segue essa diferenciação, pois apenas a nuvem do f.209, referente a essa passagem, é de cor branca. Nas demais (ff. 43v, 176v-177 e $182 \mathrm{v})$, a nuvem é de cor azul.

\footnotetext{
${ }^{251}$ Disponível em: 〈http://bdh-rd.bne.es/viewer.vm?pid=d-1806167>. Acesso em: 25 nov. 2015.

${ }^{252}$ BOLMAN, Elizabeth S. De coloribus: the Meanings of color in Beatus manuscripts. Gesta, vol. 38, $\mathrm{n}^{\circ} .1$, p.22-34, 1999

${ }^{253}$ BOLMAN, Elizabeth S. De coloribus: the Meanings of color in Beatus manuscripts. Gesta, vol. $38, \mathrm{n}^{\circ} .1$, p.22-34, 1999, p. 24.

${ }^{254}$ No estudo de Bolman, há uma pequena confusão quanto aos fólios do Beatus de Facundus. Ela indica que a figuração do Ap 10,11 acontece nos ff. 138v-139, quando, na verdade, esses fólios são ocupados pela imagem do altar e as almas dos mortos (Ap 6, 9-11) e o começo da explanatio referente a essa passagem. O trecho em questão, Ap 10,11, é figurado nos ff. 176v-177. BOLMAN, Elizabeth S. De coloribus: the Meanings of color in Beatus manuscripts. In: Gesta, vol. 38, n . 1, 1999, p.32, nota 27.

255 "Incipit historia de nube alba et de Filio Hominis in Libro VII. Et vidi, et ecce nubem albam: et super nubem similem filio hominis, habentem in capite suo coronam auream, et in manu sua habebat falcem acutam - Começa a história da nuvem branca e do filho do homem no livro VII. Olhei então e havia uma nuvem branca e sobre a nuvem alguém sentado semelhante a um Filho de Homem, que levava na cabeça uma coroa de ouro e na mão uma foice afiada." CAMPO HERNÁNDEZ, Alberto del; FREEMAN, Leslie G.; GONZÁLEZ ECHEGARAY, Joaquín (ed.). Beato de Liébana. Obras completas y complementarias. Edição bilíngue do latim ao castelhano. Madrid: Biblioteca de Autores Cristianos, 2004, v. 1, p. 510-511, tradução nossa.
} 


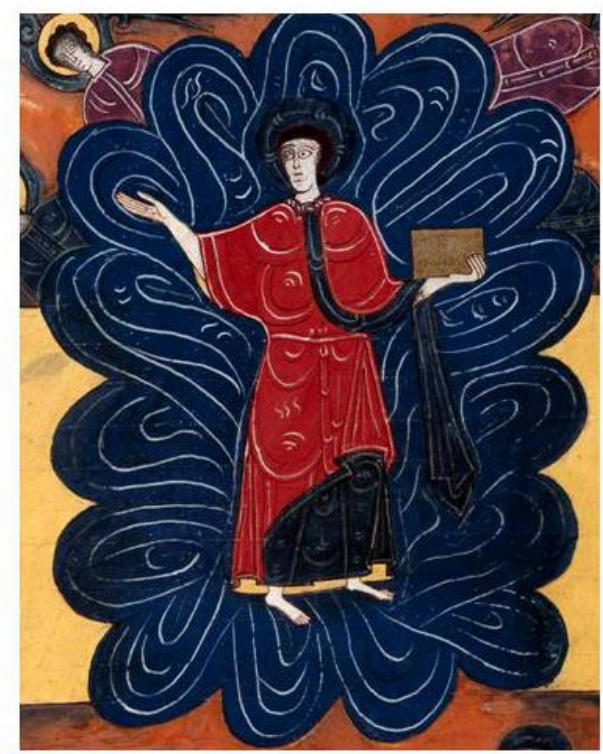

f.43v

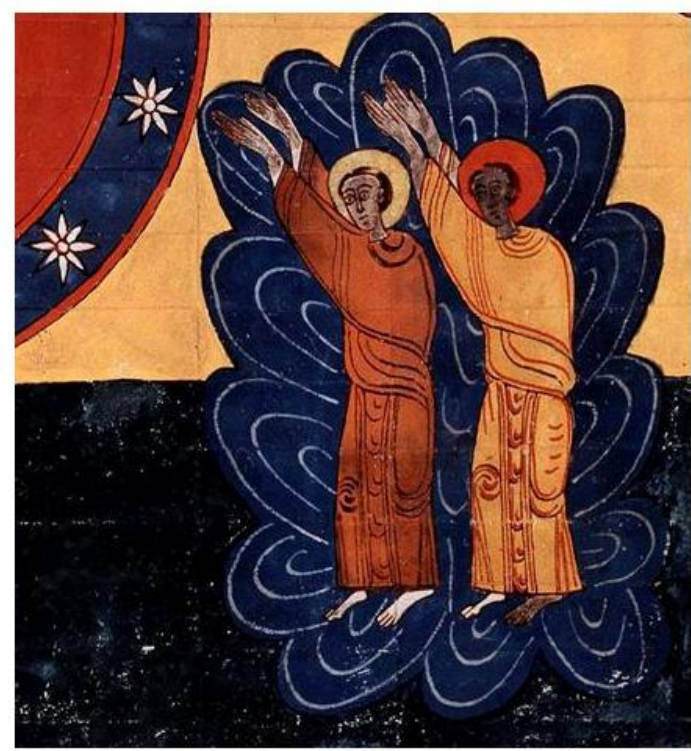

f. $182 \mathrm{v}$

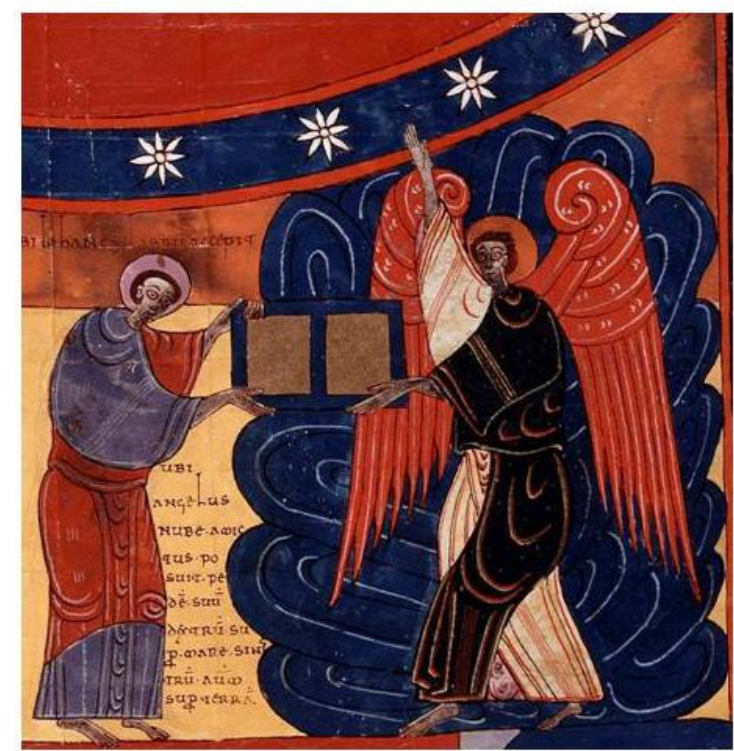

f. $176 \mathrm{v}$

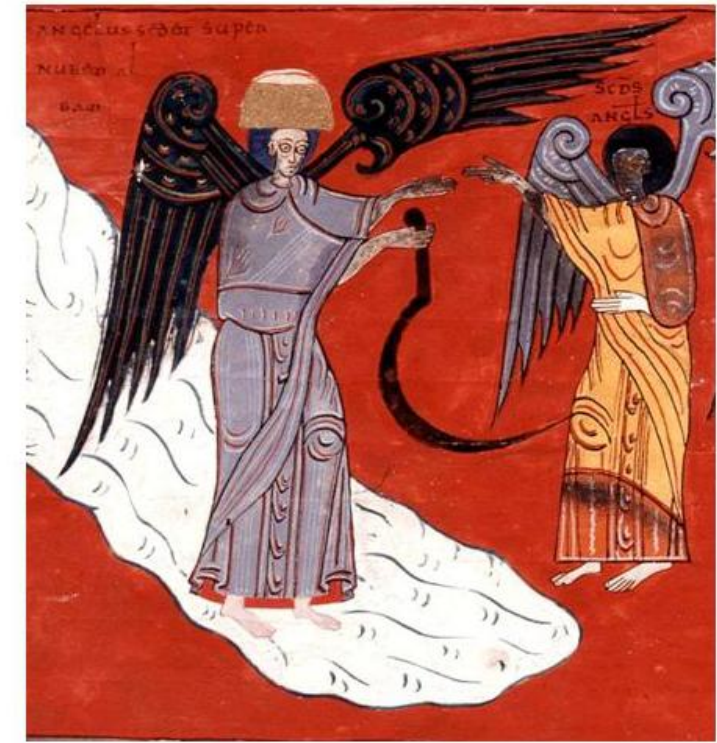

f. 209

Figura 20. Beatus de Facundus. Figuração de nuvens. Fonte: www.bne.es (montagem da autora)

Para Bolman, o papel iconográfico exercido nas escolhas das cores relaciona-se não apenas com a cor que ocupa a maior extensão de uma imagem, ou seja, aquela que nos permite caracterizar um objeto como de determinada cor, como uma blusa que é azul independente de qualquer outro traço menor que contenha de outra cor, mas a cor, no medievo, é também aquela menor parte do objeto que pode ganhar significado. Uma veste azul pode significar mais por seu contorno branco, que o próprio preenchimento azul. A autora cita a nuvem da passagem do Ap. 14, 14, a "nubem albam", que no Beatus de Morgan 
(f. 178v) é amarela com contorno branco, para mostrar que a linha branca de contorno pode adquirir papel iconográfico, que sua presença não é casual. Segundo a autora, a linha branca poderia referir-se, mesmo que sutilmente, a cor comentada no texto. ${ }^{256}$ A cor não é apenas essa zona de maior abrangência de um objeto (como preenchimento), mas é também a linha que define seu corpo. Uma linha não é de coloração branca, no medievo, ela é o branco. Ou seja, não há uma correspondência com a nossa noção de colorir - de preencher um objeto com uma cor, de adjetivá-lo; a cor medieval é sujeito e não adjetivo. A cor da linha pode ser o elemento significante, aquela que reitera a ligação entre texto e imagem, em comparação ao campo de cor que circunda. ${ }^{257}$ Sobre a linha como cor, a nuvem do f. 209, no Beatus de Facundus, é branca com linhas azuis, enquanto as nuvens das outras três imagens (ff. 43v, 176v-177 e 182v) são azuis com linhas brancas. Não há referência às nuvens serem azuis ou brancas. A figuração da cor azul não pode ser explicada apenas pela ausência de designação textual. Compreendemos o peso do valor iconográfico para a escolha, mas a configuração formal da nuvem não se limita a essa indicação. Ausência de cor de nuvem não significa, de modo estrito, nuvem azul. Seria o uso da cor azul uma referência ao mundo natural? O correspondente natural seria a nuvem branca e não a azul, o que não anula, necessariamente, a associação das nuvens à cor azul em extensão ao campo azul do céu, de mesmo modo que o valor natural significante nas imagens concentre-se na linha branca e não no corpo azul da nuvem. Olhemos para o céu e veremos um largo campo de cor azul ornado por diferentes formas de linhas brancas.

Podemos ir um pouco além das observações de Bolman. Encontramos o motivo iconográfico e de referência ao mundo natural para a escolha da cor de figuração das nuvens, como sugere Bolman, ${ }^{258}$ e ainda observamos que as escolhas pautam-se em referência às outras imagens com nuvens dentro do manuscrito, ou seja, as cores se constroem em referência à série. Não seria casual a relação entre "nuvem branca de linhas azuis" e "nuvem azul de linhas brancas", nem mesmo quanto à composição da forma dessas nuvens. A relação das cores (e da forma) pode ser pensada através do que Jean-Claude Bonne chama de dobra

\footnotetext{
${ }^{256}$ BOLMAN, Elizabeth S. De coloribus: the Meanings of color in Beatus manuscripts. Gesta, vol. $38, \mathrm{n}^{\circ} .1$, p.22-34, 1999, p. 24.

${ }^{257}$ BOLMAN, Elizabeth S. De coloribus: the Meanings of color in Beatus manuscripts. Gesta, vol. $38, \mathrm{n}^{\circ} .1$, p.22-34, 1999, p. 25.

${ }^{258}$ Bolman aponta para algumas possibilidades de figuração da cor segundo sua referência ao mundo natural na figuração de estrelas, fogo, granizo, sangue, pele, água e metais preciosos. BOLMAN, Elizabeth S. De coloribus: the Meanings of color in Beatus manuscripts. Gesta, vol. 38, n. 1, p.22-34, 1999, p.26-27.
} 
(pliure, em francês), uma categoria sintática descrita, por Bonne, como um modo de associar elementos e torná-los relacionáveis entre si. ${ }^{259}$

\begin{abstract}
A dobra cumpre essencialmente funções paradigmáticas e de fechamento. Ela fecha a representação em si mesma, soldando aí, por seus jogos de espelho, o mundo a si mesmo em seu fracionamento e até mesmo em suas oposições. Por princípio, uma unidade qualquer - figura ou ornamento, detalhe ou conjunto - demanda uma imagem de si mesma, ou uma contra-imagem, no interior de si, em outra unidade ou em uma série. Essa imagem pode ser idêntica ou complementar, diferenciada ou invertida, presente, distante ou subentendida. ${ }^{260}$
\end{abstract}

A correspondência traça uma conexão dialógica entre as imagens e, por aproximação, as faz ocupar um lugar equivalente, mas também as distancia em dois grupos distintos. A linha branca na nuvem azul remete à linha azul na nuvem branca, aproxima as nuvens em um mesmo conjunto, mas isola a nuvem branca de linhas azuis como uma figuração única em todo o manuscrito. Além dessas quatro imagens que possuem indicação textual para a presença das nuvens, não há outra que figure nuvens, apenas o céu em sentido amplo, como lugar celeste.

O branco na nuvem azul prefigura o azul na nuvem branca, uma relação intrincada que não se executa pela simples descrição textual "nubibus" (f. 43v) ${ }^{261}$, "nube" (ff. 176v-177, $182 \mathrm{v})^{262}$ e "nubem albam" (f. 209) ${ }^{263}$. O azul das três nuvens parece aproximar as imagens que Beato de Liébana associa, na explanatio, à ideia de ressurreição, da ascensão em nuvens, bem como a nuvem que significa simbolicamente a Igreja, aquela que envolve Deus e Cristo. O que ainda não explicaria diretamente o uso das cores, nem mesmo as distanciaria da nuvem branca do f. 209. A cor das nuvens se constrói em associação entre todas as nuvens do manuscrito, não apenas ao texto que figura. A nuvem branca reforça a presença da cor no

${ }^{259}$ BONNE, Jean-Claude. Syntaxe. In: L'art Roman de face et de profil: Le tympan de Conques. Paris: Le Sycomore, 1984, p.183-200.

${ }^{260}$ BONNE, Jean-Claude. L'art Roman de face et de profil: Le tympan de Conques. Paris: Le Sycomore, 1984, p.183, traduzido por Eduardo H. Aubert.

${ }^{261}$ CAMPO HERNÁNDEZ, Alberto del; FREEMAN, Leslie G.; GONZÁLEZ ECHEGARAY, Joaquín (ed.). Beato de Liébana. Obras completas y complementarias. Edição bilíngue do latim ao castelhano. Madrid: Biblioteca de Autores Cristianos, 2004, v. 1, p. 78.

${ }^{262}$ CAMPO HERNÁNDEZ, Alberto del; FREEMAN, Leslie G.; GONZÁLEZ ECHEGARAY, Joaquín (ed.). Beato de Liébana. Obras completas y complementarias. Edição bilíngue do latim ao castelhano. Madrid: Biblioteca de Autores Cristianos, 2004, v. 1, p. 434-345 e p.448-449.

${ }^{263}$ CAMPO HERNÁNDEZ, Alberto del; FREEMAN, Leslie G.; GONZÁLEZ ECHEGARAY, Joaquín (ed.). Beato de Liébana. Obras completas y complementarias. Edição bilíngue do latim ao castelhano. Madrid: Biblioteca de Autores Cristianos, 2004, v. 1, p. 510-511. 
texto ao qual a imagem se relaciona. Beato de Liébana traz, nos comentários, uma explicação para a cor.

\begin{abstract}
A nuvem branca se refere à Igreja que brilha na claridade de sua paciência. O filho do homem se refere a Cristo que é dono de sua Igreja. Esta nuvem branca brilhará agora na paixão, mas sobretudo irá branquear pelas chamas da perseguição na ressurreição. ${ }^{264}$
\end{abstract}

Essa passagem nos remete a explanatio do Ap. 1,7-11 (f. 43v), em que Cristo aparece na nuvem (azul de linhas brancas, na imagem) como aquele que morre para purificar os pecados, que "[...] primeiro vem oculto no homem assumido, [que] virá pouco depois manifesto em majestade e glória para julgar". ${ }^{265}$ O Cristo, na imagem do f. 209, vem na nuvem branca com uma foice afiada, que ceifa a terra, que executa o julgamento divino. As cores nas nuvens dessas imagens remetem mais a uma existência delas dentro de uma série com explicação simbólica que a uma referência ao mundo natural. O branco da nuvem, que é a Igreja, no f. 209, é o mesmo branco das linhas da Igreja que reveste Cristo nas outras imagens. Também é o mesmo branco que Beato de Liébana associa, na explanatio do Ap. 10, 1-11 (ff. 176v-117), às veste brancas de Cristo que são as vestes da Igreja através de uma associação ao livro de Daniel 7, 9. ${ }^{266}$

Mas, por que nuvens azuis e não amarelas, como no Beatus de Morgan? Se observarmos a composição das imagens com nuvens azuis, veremos que a escolha das cores estabelece uma interessante relação entre as cores azul, vermelha e branca. Na imagem do f. $43 \mathrm{v}$, a cor vermelha é a cor das vestes de Cristo, ${ }^{267}$ nas imagens dos ff. $176 \mathrm{v}$ e $182 \mathrm{v}$, o vermelho é a cor da figuração do lugar celeste, aquele ao qual os personagens se direcionam, sobretudo com o gesto das mãos (para as imagens inteiras, ver Anexo F). Este lugar celeste,

\footnotetext{
${ }^{264}$ CAMPO HERNÁNDEZ, Alberto del; FREEMAN, Leslie G.; GONZÁLEZ ECHEGARAY, Joaquín (ed.). Beato de Liébana. Obras completas y complementarias. Edição bilíngue do latim ao castelhano. Madrid: Biblioteca de Autores Cristianos, 2004, v. 1, p. 510-511.

${ }^{265}$ CAMPO HERNÁNDEZ, Alberto del; FREEMAN, Leslie G.; GONZÁLEZ ECHEGARAY, Joaquín (ed.). Beato de Liébana. Obras completas y complementarias. Edição bilíngue do latim ao castelhano. Madrid: Biblioteca de Autores Cristianos, 2004, v. 1, p. 78-79.

${ }^{266}$ Daniel 7,9 "Eu continuava contemplando, quando foram preparados alguns tronos, e um Ancião sentou-se. Suas vestes eram brancas como a neve; e os cabelos de sua cabeça, alvos como a lã". BÍBLIA. Português. Bíblia de Jerusalém. São Paulo: edição Paulus, 2010, p. 1567.

267 A cor que predomina é a vermelha, mas também encontramos nas vestes de Cristo o preto azulado, a cor amarela (relação com a banda de cor amarela em que a nuvem se encontra) e uma pequena porção em púrpura (também encontrada nos anjos, nos personagens do estrato inferior e na borda da imagem).
} 
ocupado ou não figurativamente pelo Cristo, é composto de vermelho (campo), azul (borda) e branco (ornamento da borda em forma de estrelas). ${ }^{268}$ As cores dizem mais de suas dobras (espelhamento e relação serial) que de uma simbologia imutável ou uma escolha direcionada apenas pelo texto.

Se fôssemos destacar uma cor, dentre as que são utilizadas no Beatus de Facundus, como aquela que melhor evidencia sua presença iconográfica, simbólica e de relação com o mundo natural, diríamos que é o ouro. O ouro é matéria e luz e possui um status particular ao participar da simbologia dos metais, sendo calor, peso e densidade. ${ }^{269} \mathrm{O}$ ouro mantém uma parte de suas propriedades materiais do mundo natural, como o brilho, quando transposto à planaridade da página, assim como é um símbolo honorífico.

Devido à sua substância metálica, o ouro é a única das cores que tem uma conotação de materialidade com características objetivas intrínsecas, sua qualidade de metal precioso o outorga um extraordinário valor ornamental, é ornamento por mera presença, inclusive sem nenhum tipo de articulação decorativa. ${ }^{270}$

No f. 209, a escolha do ouro na coroa do anjo que desce na nuvem, que é também Cristo e Igreja, segue a indicação textual: "[...] que levava na cabeça uma coroa de ouro [coronam auream] e na mão uma foice afiada". ${ }^{271}$ A coroa ainda aparece na explanatio de Beato de Liébana sobre a seguinte passagem: "Eles são os vinte e quatro anciãos, com suas coroas de ouro [coronis aureis]". ${ }^{272}$ A escolha pelo uso do ouro como cor que concebe honra é mais evidente no seu uso em elementos que não guardam uma relação iconográfica, que se distanciam das tensões com a representação, como nos entrelaços e em outros ornamentos das bordas das imagens.

No f.6, os entrelaços em ouro compõem a honra dedicada ao Alfa, que é Cristo e Senhor (Figura 21). Apesar de não fazer parte do corpus do Comentário ao Apocalipse (ff. 40-

\footnotetext{
${ }^{268}$ Sobre o estudo do lugar celeste, ver capítulo 5.

${ }^{269}$ PÄCHT, Otto. La miniatura medieval: una introducción. Madrid: Alianza Editorial, 1987, p. 140.

${ }^{270}$ PÄCHT, Otto. La miniatura medieval: una introducción. Madrid: Alianza Editorial, 1987, p. 140-141.

${ }^{271}$ CAMPO HERNÁNDEZ, Alberto del; FREEMAN, Leslie G.; GONZÁLEZ ECHEGARAY, Joaquín (ed.). Beato de Liébana. Obras completas y complementarias. Edição bilíngue do latim ao castelhano. Madrid: Biblioteca de Autores Cristianos, 2004, v. 1, p. 510-511.

272 CAMPO HERNÁNDEZ, Alberto del; FREEMAN, Leslie G.; GONZÁLEZ ECHEGARAY, Joaquín (ed.). Beato de Liébana. Obras completas y complementarias. Edição bilíngue do latim ao castelhano. Madrid: Biblioteca de Autores Cristianos, 2004, v. 1, p. 510-511.
} 
264), a imagem do Alfa, que inicia o manuscrito, possui uma referência iconográfica no Ap. 1, 8: “Eu sou o alfa e o ômega, o princípio e o fim, diz o Senhor Deus, o que é, o que era e o que virá, o Todo-poderoso". ${ }^{273} \mathrm{Na}$ imagem há uma dupla alusão à figura de Cristo, por sua própria presença abaixo do alfa e pela figuração das letras gregas, que Beato de Liébana reforça serem associadas à trindade. Segundo a explanatio, a figura da letra alfa, "A", é formada por três traços de igual tamanho, que significa a unidade da divindade, e o ômega " $\omega$ " assim está escrito, em grego, para que as partes dependam entre si. ${ }^{274}$ Não observamos, na imagem, a figuração da letra alfa em três traços de mesmo tamanho, pois sua monumentalidade ornamental e a presença do Cristo exigem uma maior extensão na vertical. O ouro que compõe os entrelaços do alfa toca o corpo em ouro da letra ômega e a auréola cruciforme do Cristo, são todos da mesma matéria em mostra de sua unicidade e honra.

\footnotetext{
${ }^{273}$ CAMPO HERNÁNDEZ, Alberto del; FREEMAN, Leslie G.; GONZÁLEZ ECHEGARAY, Joaquín (ed.). Beato de Liébana. Obras completas y complementarias. Edição bilíngue do latim ao castelhano. Madrid: Biblioteca de Autores Cristianos, 2004, v. 1, p. 78-79. A relação entre Deus e as letras gregas mostra-se também em outros textos bíblicos como Ap. 1, 17: "Ao vê-lo, caí como morto a seus pés. Ele, porém, colocou a mão direita sobre mim assegurando: 'Não temas! Eu sou o Primeiro e o Último [...]"”; Ap. 2, 8: "Ao Anjo da Igreja em Esmirna, escreve: Assim diz o Primeiro e o Último, aquele que esteve morto mas voltou à vida”; Ap. 21, 6: "Disse-me ainda: 'Elas se realizaram! Eu sou o Alfa e o Ômega, o Princípio e o Fim; e a quem tem sede eu darei gratuitamente da fonte de água viva [...]". Ap. 22, 13: "Eu sou o Alfa e o Ômega, o Primeiro e o Último, o Princípio e o Fim". Assim como dois trechos do livro de Isaias (Is. 41, 4 e Is. 44, 6).

${ }^{274}$ CAMPO HERNÁNDEZ, Alberto del; FREEMAN, Leslie G.; GONZÁLEZ ECHEGARAY, Joaquín (ed.). Beato de Liébana. Obras completas y complementarias. Edição bilíngue do latim ao castelhano. Madrid: Biblioteca de Autores Cristianos, 2004, v. 1, p. 78-79.
} 


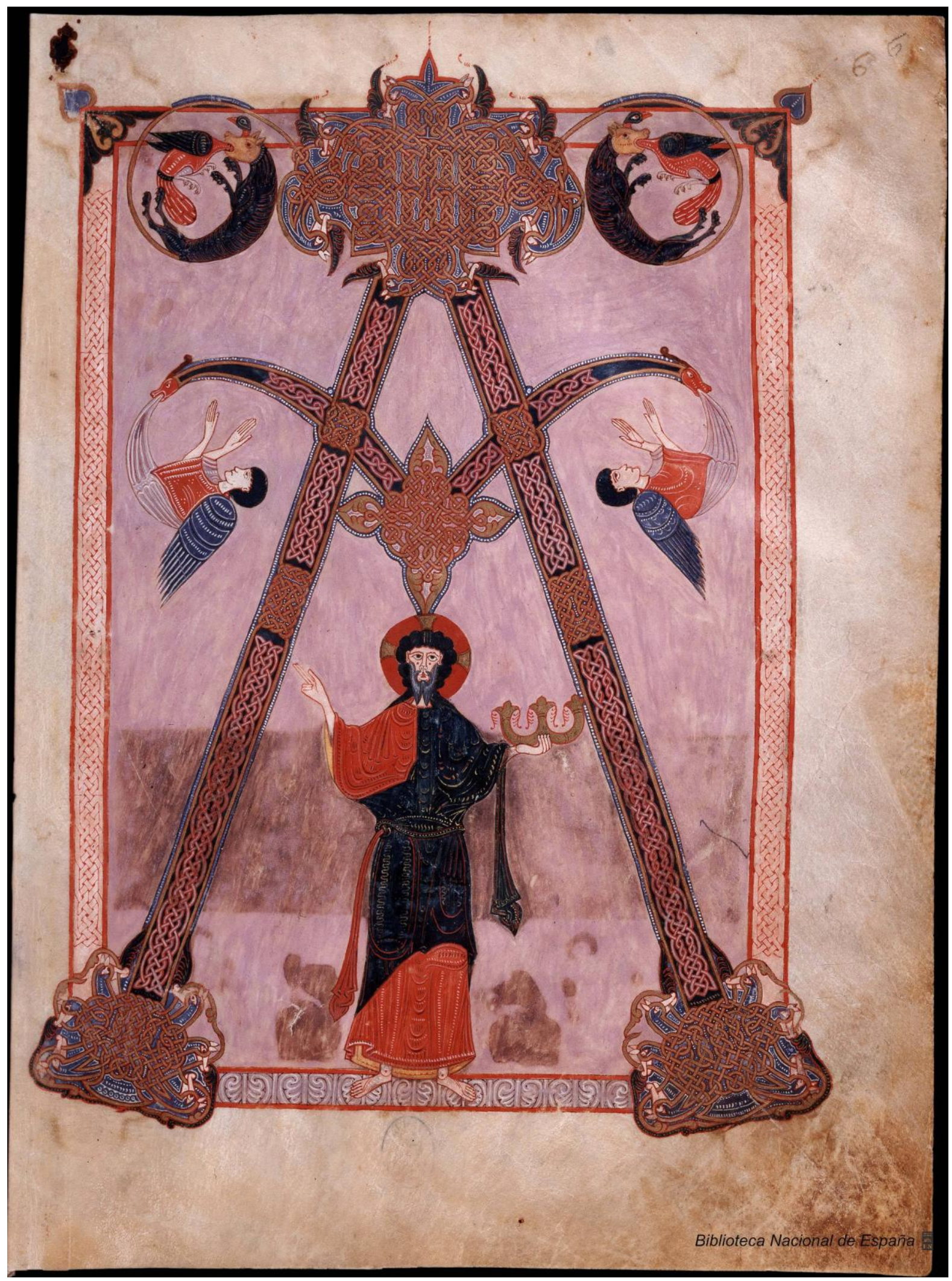

Figura 21. Beatus de Facundus, f.6, Alfa.

Fonte: www.bne.es 
Também podemos observar que a passagem do Ap. 1,8 aparece na storia, e também na explanatio, relacionada ao f. $43 \mathrm{v} .{ }^{275}$ A aproximação entre as duas imagens é vista principalmente nas vestes do Cristo. Em ambas, as vestes são compostas, em sua maior extensão, pelas cores vermelha e preta azulada, dispostas de modo espelhado, e a cor amarela compõe a parte interna das vestes. Se no f.43v a cor amarela poderia relacionar-se diretamente à banda de cor onde se localiza o Cristo, bem como à cor amarela que compõe as linhas externa e interna da borda ornamentada desta imagem, no f. 6 não encontraríamos tal correspondência visual dentro da própria imagem, mas fora dela. No f. 43v ainda há uma pequena porção de cor púrpura, no limite entre a veste e o rosto de Cristo, que não aparece no f. 6, senão em referência à cor distribuída monocromaticamente, mas em diferente valor e saturação, sobre todo o campo da imagem. ${ }^{276}$ Dizemos campo, ao invés de fundo, para sublinhar que se trata do espaço entre figuras e não necessariamente um espaço rígido e fixo no último plano da imagem. A púrpura pode exercer, nesta imagem, um símbolo imperial, em associação ao imperador celeste ou terrestre. ${ }^{277}$ Segundo a tradição romana,

[...] a cor púrpura era um privilégio ferozmente defendido por aqueles que gozavam de certa proeminência social. [...] Mas essa também era a cor preferida do imperador, o último grito naquele meado de século, e Nero achou por bem impor regras bastante rígidas que controlassem seu uso. ${ }^{278}$

Os imperadores otonianos recuperaram essa tradição da Antiguidade e o rei de Leão, também, provavelmente por seu intermédio. Ela é utilizada em várias imagens do Beatus de Facundus, mas de modo mais comedido que no f.6. Aparece, sobretudo, nos entrelaços do f.7, no qual encontramos a cor em figuração ao lado dos nomes dos doadores, bem como aparecerá, posteriormente na encomenda do Diurnal, também como elemento inaugural do

\footnotetext{
${ }^{275}$ Disponível em: 〈http://bdh-rd.bne.es/viewer.vm?pid=d-1806167>. Acesso em: 25 nov. 2015.

${ }^{276}$ Apenas em mais uma imagem do Beatus de Facundus encontramos um campo monocromático dentro de uma imagem com borda: f. 214 (Os sete anjos com as copas). Não há uma referência que posa justificar essa ocorrência, ao menos não aparente. Contudo, podemos pensar no esforço de Beato de Liébana em fazer o texto retomar, pela explanatio, o começo do Apocalipse "Pois assim descrevemos no começo deste livro a Cristo, que teria um cinturão de ouro sobre o peito, para que creia que este é o mesmo (Ap 1,13)". CAMPO HERNÁNDEZ, Alberto del; FREEMAN, Leslie G.; GONZÁLEZ ECHEGARAY, Joaquín (ed.). Beato de Liébana. Obras completas y complementarias. Edição bilíngue do latim ao castelhano. Madrid: Biblioteca de Autores Cristianos, 2004 , v. 1 , p. 520-521.

${ }^{277}$ Como os camafeus que remetiam a Antiguidade imperial no f. 7.

${ }^{278}$ BUTTERWORTH, Alex; LAURenCE, Ray. Pompeia: A cidade viva. Rio de Janeiro: Record, 2007, p.260
} 
manuscrito e do caráter imperial (Figura 22). ${ }^{279}$ A composição da imagem do f. 1, no Diurnal, também é semelhante a figuração no f.6 do Beatus de Facundus, com a letra alfa monumental e Cristo sob a letra, bem como os elementos figurativos circulares que formam a extremidade dos entrelaços.

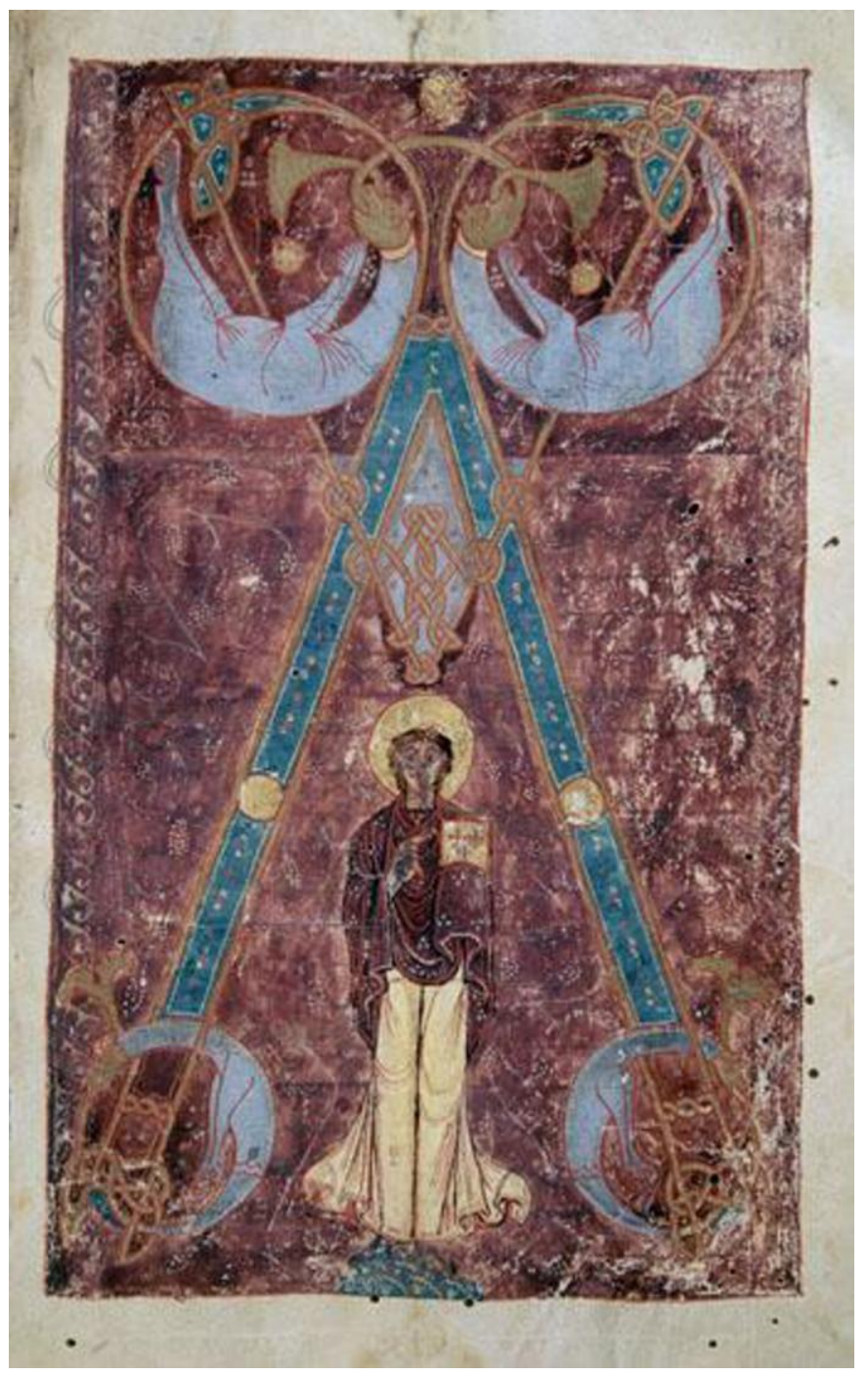

Figura 22. Diurnal de Fernando I e Sancha, f. 1, Alfa. Fonte: http://www.oronoz.com/

\footnotetext{
${ }^{279}$ A cor púrpura ainda aparece, no Diurnal, compondo o início dos salmos (f. 7v) e, sobretudo, no colofão, quando se atribui a encomenda à rainha Sanha, e realização a Pedro e Frutuoso (f. 208v). No primeiro fólio, a cor púrpura aparece de modo adjacente à figuração dos reis no f. 3. Neste fólio, há uma possível representação dos reis, ladeando um personagem laico. Hipólito Escolar afirma que tradicionalmente esta miniatura é associada a uma dedicatória, em que se identifica entre o casal real a representação do miniaturista, Fructuoso, que apresenta o livro e o entrega aos comitentes. Escolar ainda fala da hipótese de Yarza Luaces- em que o casal real estaria acompanhado do rei Davi, representação comum à arte carolíngia tardia e à arte otoniana. Mostrarse-ia, assim, a glória do rei e seu caráter de eleito por Deus por seu paralelismo com o rei Davi. No entanto, pensamos que a ausência de coroa no personagem ao centro exclui a ideia de que seja representação do rei Davi. De todo modo, não há dúvidas quanto à representação do casal real. ESCOLAR, Hipólito. Los manuscritos: historia ilustrada del libro español. Madrid: Fundación Germán Sánchez Ruipérez, 1996, p. 310.
} 
A cor púrpura não possui significado quando pensada em desconexão com o contexto, ou seja, a significação dos elementos em uma imagem se dá na sua utilização. Quando a cor púrpura é inserida no contexto da miniatura do Alfa, ela passa a ser ornamental, tem seu peso estético destinado a uma significação simbólica, de representação do caráter imperial. A funcionalidade do elemento ornamental justifica-se dentro de uma tradição ao ser combinada com outros elementos, por meio de composições significativas e ao exprimir as necessidades de emblematizar e de celebrar uma ordem identificável numa determinada sociedade. No caso da cor púrpura, ela trabalha ao identificar um status e fornecer significações à imagem, ao manuscrito, aos comitentes e à identidade do reinado de Fernando I. Seu uso constante nas encomendas reais torna a cor púrpura um instrumento que demonstra a fecundidade dessa tradição simbólica.

Contudo, será que sempre que a cor púrpura for utilizada no manuscrito será devido a um motivo simbólico? Se retirarmos do entorno do campo púrpura o alfa monumental, os entrelaços e outros elementos em ouro, sua localização como primeira imagem do manuscrito e sua relação com a imagem do f.7, o labirinto, essa cor ainda seria considerada uma cor de símbolo imperial? Pode ser que estejamos diante do valor ornamental da variedade cromática. A varietas, segundo Bolman, seria um dos motivos para a escolha de uso de uma cor em detrimento de outra, junto das referências iconográfica, simbólica e ao mundo natural. ${ }^{280}$

A autora utiliza, em seu trabalho, dois tratados de técnicas de manufatura de pigmentos que também falam sobre a ideia de variedade da cor. São eles o tratado de Eraclius, De coloribus et artibus Romanorum, do século XI, e o tratado de Teófilo, De diversis artibus, do século XII. Bolman cita a descrição de Teófilo do templo da sabedoria sagrada para compreender como a diversidade cromática foi utilizada nos Beati.

[o templo] é um lugar 'preenchido com uma variedade de todos os tipos de cores com a utilidade e a natureza de cada uma que é estabelecida'. No caso de varietas, não importa se estas cores foram principalmente pensadas como tons ou como áreas sobre uma escala de valores. A questão é sua diferença e sua profusão. Esta apreciação comum para a diversidade se manifestou com a cor de uma forma específica no norte da Espanha. ${ }^{281}$

\footnotetext{
${ }^{280}$ BOLMAN, Elizabeth S. De coloribus: the Meanings of color in Beatus manuscripts. Gesta, vol. $38, \mathrm{n}^{\circ} .1$, p.22-34, 1999.

${ }^{281}$ BOLMAN, Elizabeth S. De coloribus: the Meanings of color in Beatus manuscripts. Gesta, vol. 38, $\mathrm{n}^{\circ} .1$, p.22-34, 1999, p. 27-28, tradução nossa.
} 
Essa especificidade estaria, para Bolman, nas variedades da variedade (for varieties of variety), ${ }^{282}$ ou seja, a variedade não existe apenas no simples uso de uma grande gama de cores, mas na cor pensada segundo uma variedade de lógicas composicionais. ${ }^{283}$ Ela cita sete princípios de varietas nos manuscritos dos Beati, observados dentro de uma mesma imagem, nos elementos figurativos: Repetição linear espelhada (1), repetição espelhada ao longo de uma diagonal (2), repetição de um padrão linear (3), pares regularmente coloridos em duas zonas (4), padrão linear invertido em zona inferior (5), elementos que enquadram um padrão regular (6) e como elementos que enquadram um padrão irregular (7).

Como visualização explicativa das sete classificações, ela propõe a seguinte figura:

Type 1: linear mirrored repetition A A

or:

ABC CBA

Type 2: mirrored repetition along a diagonal grid<smiles>[3H]C([B])([B])[B]</smiles>

Type 3: linear (horizontal or vertical) repetition of a pattern:

ABABABABABAB

or: ABCBABCBABCBA

or:
A C B A C
B A C B A
C B A C B

Type 4: regularly colored pairs in two zones:

A B C D E F G

Type 5: linear pattern reversed in

$\mathrm{AB} \quad \mathrm{CD}$ lower zone:

DC BA

Type 6: like elements framing a regular pattern:

A BCDCBCDC A

Type 7: like elements framing an irregular pattern:

\section{A BCDEFGHI A}

Figura 23. Princípios de varietas nos Beati. Fonte: Bolman, 1999. ${ }^{284}$

\footnotetext{
${ }^{282}$ BOLMAN, Elizabeth S. De coloribus: the Meanings of color in Beatus manuscripts. Gesta, vol. $38, \mathrm{n}^{\circ} .1$, p.22-34, 1999, p.28.

${ }^{283}$ Observamos algumas destas lógicas durante a análise das nuvens e das vestes do Cristo.

${ }^{284}$ BOLMAN, Elizabeth S. De coloribus: the Meanings of color in Beatus manuscripts. Gesta, vol. $38, \mathrm{n}^{\circ} .1$, p.22-34, 1999, p.28
} 
Através destes princípios, Bolman lida com "Padrões e cores que trabalham juntos". ${ }^{285}$ Em seus esquemas, a autora utiliza o alfabeto em substituição aos nomes das cores, visto que a nomeação, assim como as cores, é construída historicamente. Por exemplo, o que chamamos de púrpura, até então, compreende uma gama de matiz nos quais identificamos o vermelho, o azul, também o roxo e variações segundo os graus de saturação e brilho. ${ }^{286}$ A cor púrpura pode referir-se a um azul arroxeado, um vermelho violetado, um malva, um violeta, e muitas outras variações possíveis. Na imagem do f.6, a cor púrpura é distinta da cor, também nomeada como púrpura, do f.1 do Diurnal. Pensemos também nas variações linguísticas para referir-se a outras cores, como a branca: albus, candidus, ${ }^{287}$ niveus - distintas visualmente por branco opaco, branco cintilante e branco cor de neve, respectivamente. ${ }^{288}$ Os matizes não possuem um limite tão bem definido e, por esse motivo, Bolman nos faz atentar para as nomeações, em inglês, correspondentes ao século XX, que melhor atendem, segundo ela, a nomeação da cor também como construção histórica. ${ }^{289}$ Nessas nomeações, as palavras de cor são hifenizadas e a predominância da cor está no segundo nome: orange-red é uma cor vermelha que tende ao laranja, em português, o matiz "vermelho alaranjado". Ela utiliza essas nomeações para identificar padrões de repetição de uma "mesma" cor, que em seus esquemas é substituída por uma letra.

Para o estudo do trabalho da cor nas imagens do Beatus de Facundus, optamos pela análise das cores não apenas dentro da imagem, mas também dentro de uma série, porque é, sobretudo, dentro da série que a cor se constrói. Para a identificação das cores, optamos pela substituição por números, e não por letras, devido a três fatores. Primeiro, o corpo gráfico do número nos distancia ainda mais do nome da cor. Pareceu-nos mais adequado chamar a cor amarela de "3" que de "A". O corpo da letra parece querer que retornemos às associações modernas de cor. Em segundo lugar, que o alfabeto tem um número limite de letras, enquanto

\footnotetext{
${ }^{285}$ BOLMAN, Elizabeth S. De coloribus: the Meanings of color in Beatus manuscripts. Gesta, vol. $38, \mathrm{n}^{\circ} .1$, p.22-34, 1999, p.28.

${ }^{286}$ REINHOLD, Meyer. History of purple as a Status Symbol in Antiquity. Bruxelas: Collections Latomus, $116,1970$.

${ }^{287} \mathrm{Na}$ storia do Ap. 2, 12-17, há uma referência a uma pedrinha branca "calculum candidum", que é, segundo Beato de Liébana, na explanatio, o corpo branqueado pelo batismo "corpus baptismo candidatum". CAMPO HERNÁNDEZ, Alberto del; FREEMAN, Leslie G.; GONZÁLEZ ECHEGARAY, Joaquín (ed.). Beato de Liébana. Obras completas y complementarias. Edição bilíngue do latim ao castelhano. Madrid: Biblioteca de Autores Cristianos, 2004, v. 1, p. 206-207 e p. 216-217.

${ }^{288}$ NIERMEYER, J.F; KIEFT, C.V. Medieval Latin Dictionary. Leiden: Brill, 2002, p. 228.

${ }^{289}$ BOLMAN, Elizabeth S. De coloribus: the Meanings of color in Beatus manuscripts. Gesta, vol. $38, \mathrm{n}^{\circ} .1$, p.22-34, 1999, p. 24.
} 
que os números são infinitos. ${ }^{290}$. E, por fim, e não menos importante, por se tratar de uma escolha de ferramentas de pesquisa: nós usamos números em virtude de maior perícia pessoal em associar símbolos numéricos que letras do alfabeto.

A série a ser analisada é formada por sete imagens, presentes nos ff. 78, 82v, 87v, 92, 96, 100v e 106v. A escolha foi guiada pela aproximação entre essas imagens dentro da estrutura que propomos como ferramenta de visualização do manuscrito, à qual demos o nome de "sistema de blocos" (Anexo A). A noção de sistema nos é útil por agrupar elementos solidários através de suas relações, isto é, o sistema é uma apresentação de rede de conexões. Como no sistema computacional, em que as partes se interrelacionam para fazer funcionar uma estrutura maior e organizada, o sistema de blocos evita o isolamento e a simplificação funcional de um objeto. A ferramenta reúne, em um mesmo modo de apresentação, a morfologia dos fólios do manuscrito e a possibilidade de conexões entre eles. A organização em sistema permite uma ordenação em rede sem que se perca a possibilidade de novas sistematizações, o que não acontece exatamente nos esquemas. Um esquema simplifica uma estrutura em traços básicos, em prol de uma meta definida e não mantém a flexibilidade de um sistema. O sistema pode ser operacionalizado de diferentes modos: aproximar, distanciar, destacar e isolar blocos através de uma primeira organização lógica, que cria novas redes de organização. Trata-se de um sistema que mostra um bloco ao mesmo tempo em que evidencia que há outros blocos possíveis de serem formados.

Essa noção sistemática é uma ferramenta processual mais adequada ao estudo de uma imagem-objeto. Ela nos permite atentar para o corpo do objeto sem nos desviarmos de suas funções e relações dentro da série. O sistema de blocos inclui os fólios do Beatus de Facundus em que imagem e texto se encontram, dividem o mesmo espaço da página, mas não isola esses fólios daqueles que não são incluídos visualmente no esquema. Pelo contrário, o sistema de blocos permite pensar os fólios ocupados somente por texto, mesmo quando eles se fazem presentes apenas em suas relações visíveis nos fólios com imagens. Por ora, deixemos estas questões de tensões entre texto e imagem para o próximo capítulo e nos concentremos na distinção da série e sua análise.

\footnotetext{
${ }^{290}$ Mesmo que não utilizemos mais que 26 números de cor, é importante lembrar que em um estudo de 1976, Peter Klein encontrou 180 variações de cor no Beatus de Facundus. KLEIN, Peter K. Der altere Beatus-Kodex Vitr. 14-1 Der Biblioteca Nacional Zu Madrid: Studien Zur Kunstgeschichte. Hildesheim; New York: Olms, 1976, p. 238-239.
} 


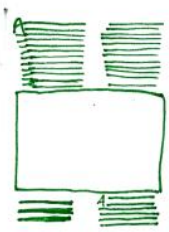

78

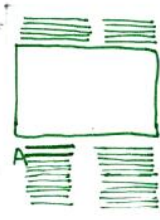

$8 \times 2$

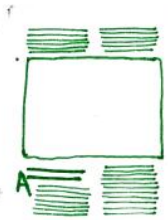

870
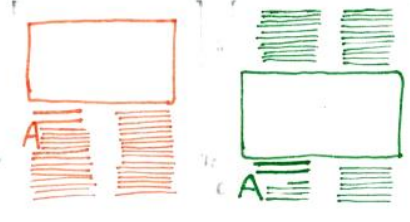

$A \overline{\overline{\equiv \equiv}}$
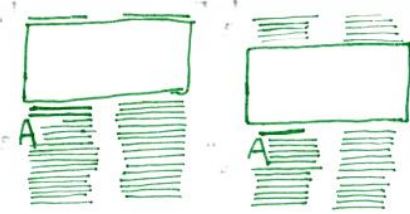

Figura 24. Sistema de blocos, ff. 78, 82v, 87v, 92, 96, 100v e 106v.

Fonte: Elaborado pela autora

As aproximações entre as imagens da série (bloco) são evidenciadas na similaridade com que ocupam o fólio: seis imagens são entremeadas por texto - com texto acima e abaixo da imagem (ff. 78, 82v, 87v, 96, 100v, 106v) - e uma imagem ocupa a parte superior do fólio e isola o texto na porção inferior (f. 92). Quando observadas dentro do sistema de blocos, a série destaca-se pela simetria de cisão do grupo de seis imagens em uma sequência de 3-1-3 (ff. 78, 82v, 87v / 92 / 96, 100v, 106v).

Apesar da cisão, as imagens do bloco possuem a mesma economia (distribuição e coordenação dos elementos de composição de modo semelhante) e aproximação iconográfica, pois os textos dos quais as imagens se originam são comuns a uma mesma sequência narrativa do Apocalipse, a entrega, por João, das sete cartas às sete igrejas da Ásia. As cartas são mensagens de Deus para as igrejas, que contam, cada uma, da situação da igreja que recebe a carta, seus problemas, seguidos de promessas ou ameaças. Cada uma das sete imagens mostra João a entregar a carta ao anjo responsável por cada uma das igrejas: primeiro ao anjo da igreja de Éfeso (f. 78; Ap. 2, 1-7), depois ao anjo de Esmirna (f. 82v; Ap. 2, 8-11), em sequência, de Pérgamo (f. 87v; Ap. 2, 12-17), de Tiatira (f. 92; Ap. 2, 18-29), de Sardes (f. 96; Ap. 3, 1-6), de Filadelfia (f. 100v; Ap. 3, 7-13) e, por fim, a carta entregue ao anjo da igreja de Laodiceia (f. 106v; Ap. 3, 14-22).

A similaridade dos esquemas compositivos evidencia a dinâmica das cores. Nos esquemas que montamos, nós identificamos o uso de cada cor por um número inserido no campo ocupado por essa cor, ou ao lado dele, no caso de pequenos detalhes, como na borda da imagem. A fim de não sobrecarregar visualmente o esquema, ocultamos a identificação das cores de padrões repetidos, como os ornamentos da borda. Por exemplo, no primeiro esquema (Figura 25), a identificação do uso das cores da borda centra-se no canto superior esquerdo e a não repetição dos números em formas iguais indica que o uso da cor também segue um 
padrão junto da forma. Além dos elementos figurativos, identificamos as cores na borda, nos campos de cor da imagem e nas iniciais capitulares.

A correlação com os números tenta reunir, em uma mesma identificação, cores de diferentes gradações. Se fossemos classificar as cores segundo suas pequenas variações, como a púrpura que tende mais ao vermelho, mais ao azul ou mais ao roxo, com toda a variedade de brilho e saturação, recorreríamos a uma noção infinita de cor. Assim como cada letra escrita por um copista é uma letra única, escrita pela primeira vez por sua mão, a cor é única em seu emprego. Pode haver uma variação cromática dentro de um mesmo campo de cor, como em um canto em que a tinta teve maior aderência na pele do pergaminho e, por isso, sua cor é mais acentuada que em outra parte do mesmo campo. Existem certos limites teóricos para se raciocinar que toda variação de cor possui um sentido exato, um motivo muito específico para seu emprego, pois, se assim o fosse, na infinidade de variações, atribuiríamos ao iluminador (ou iluminadores) uma função quase computacional. Ele seria capaz de distinguir um código de particularidade de cada uso em uma utilidade que fraciona a cor em uma cor única e isolada. Mas as cores estão em diálogo, cada uma se aproxima àquelas que possuem um corpo semelhante. Não as subdividimos segundo sua adjetivação para não tendermos a uma busca incessante das cores, o que nos levaria a trocar o título deste capítulo por "TOC: Transtorno Obsessivo pela Cor: um delírio pelo detalhe". E ainda não podemos esquecer que as cores são as mais afetadas pelo desgaste do tempo. Diante de todas essas questões, optamos por uma simplificação própria da noção de esquema, para chegarmos a algum ponto minimamente conclusivo.

Nestes esquemas adotamos para as cores a substituição por números na seguinte ordem: ouro (0), Azul (1) e azul claro (1a) ${ }^{291}$, vermelho (2), amarelo (3), preto azulado (4), púrpura (5), laranja (6), pêssego (7).

\footnotetext{
${ }^{291}$ A única cor que permitimos a identificação de uma variação foi a cor azul, na identificação de uma matiz azul (1a) que se diferencia consideravelmente dos outros azuis (1)
} 


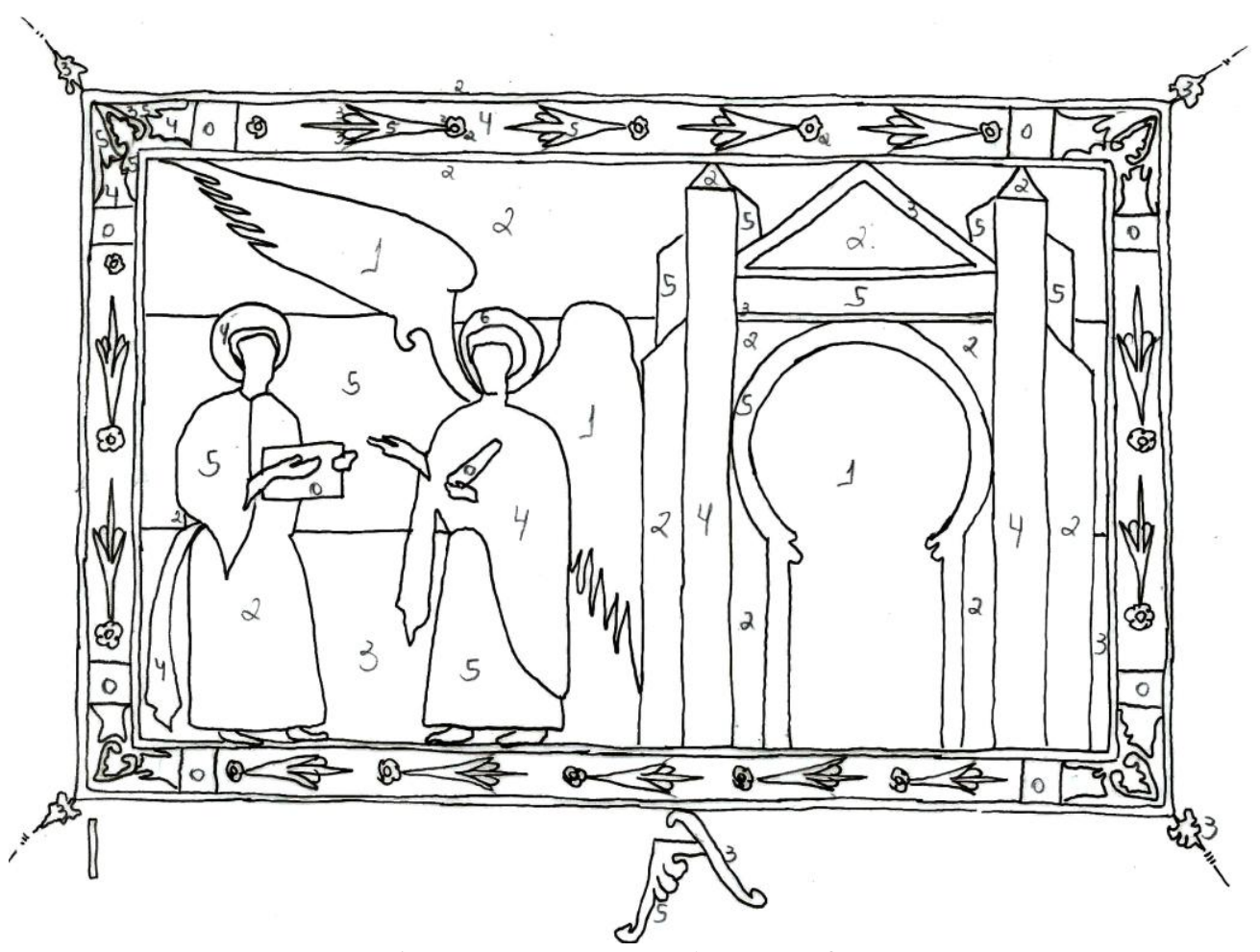

Figura 25. Esquema de cores, f. 78

Fonte: Elaborado pela autora
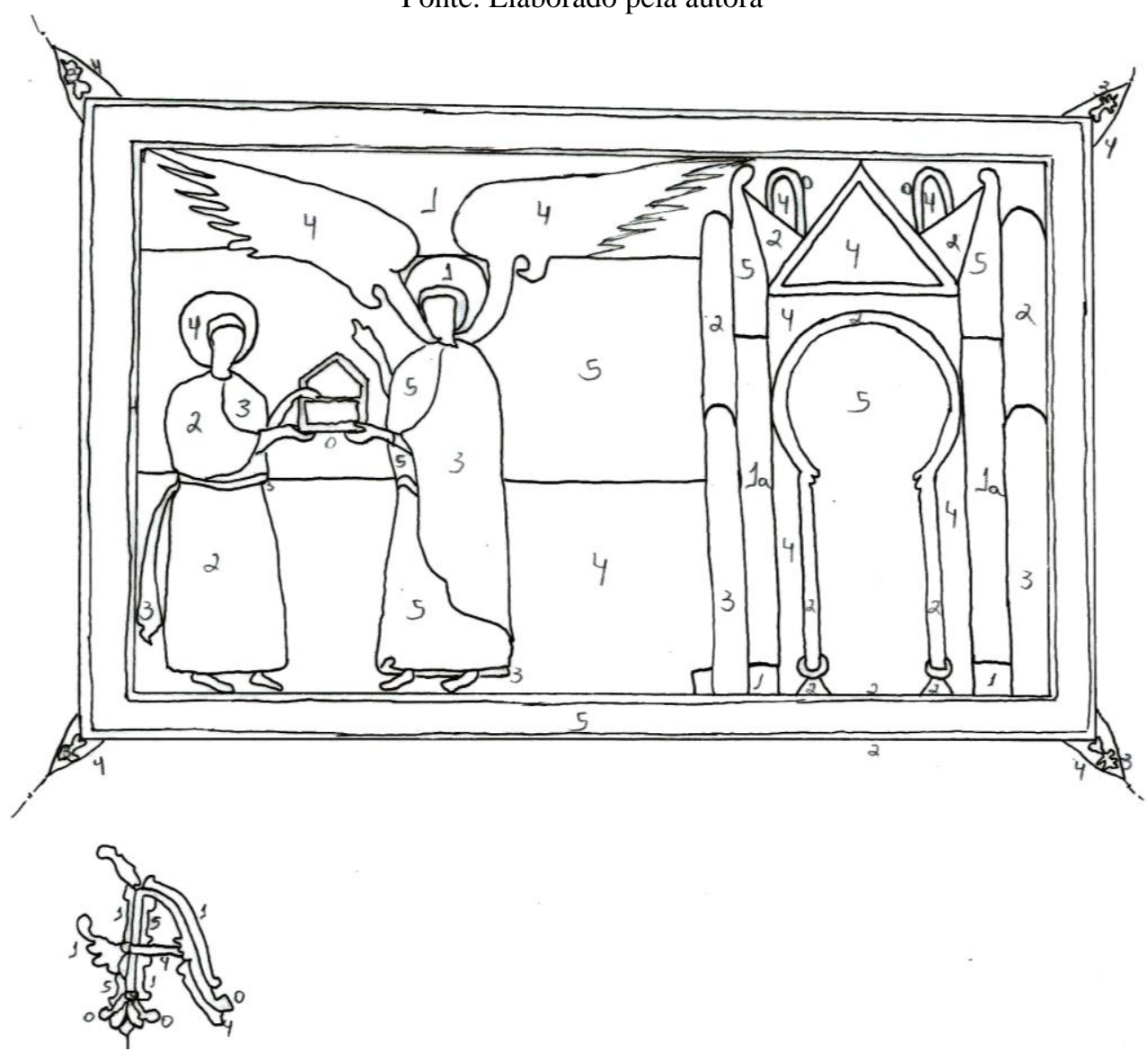

Figura 26. Esquema de cores, f. 82v

Fonte: Elaborado pela autora 


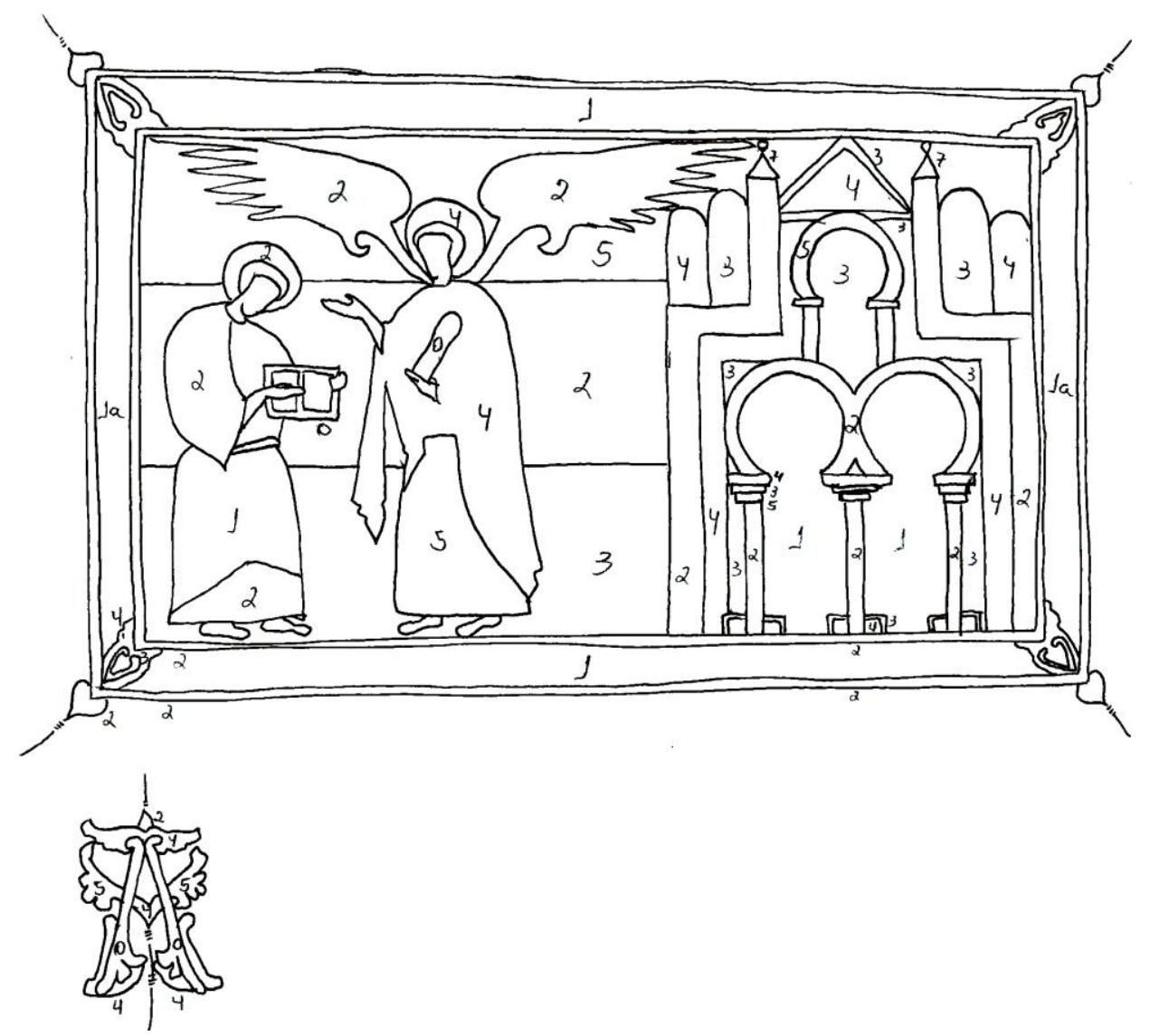

Figura 27. Esquema de cores, f. $87 \mathrm{v}$

Fonte: Elaborado pela autora

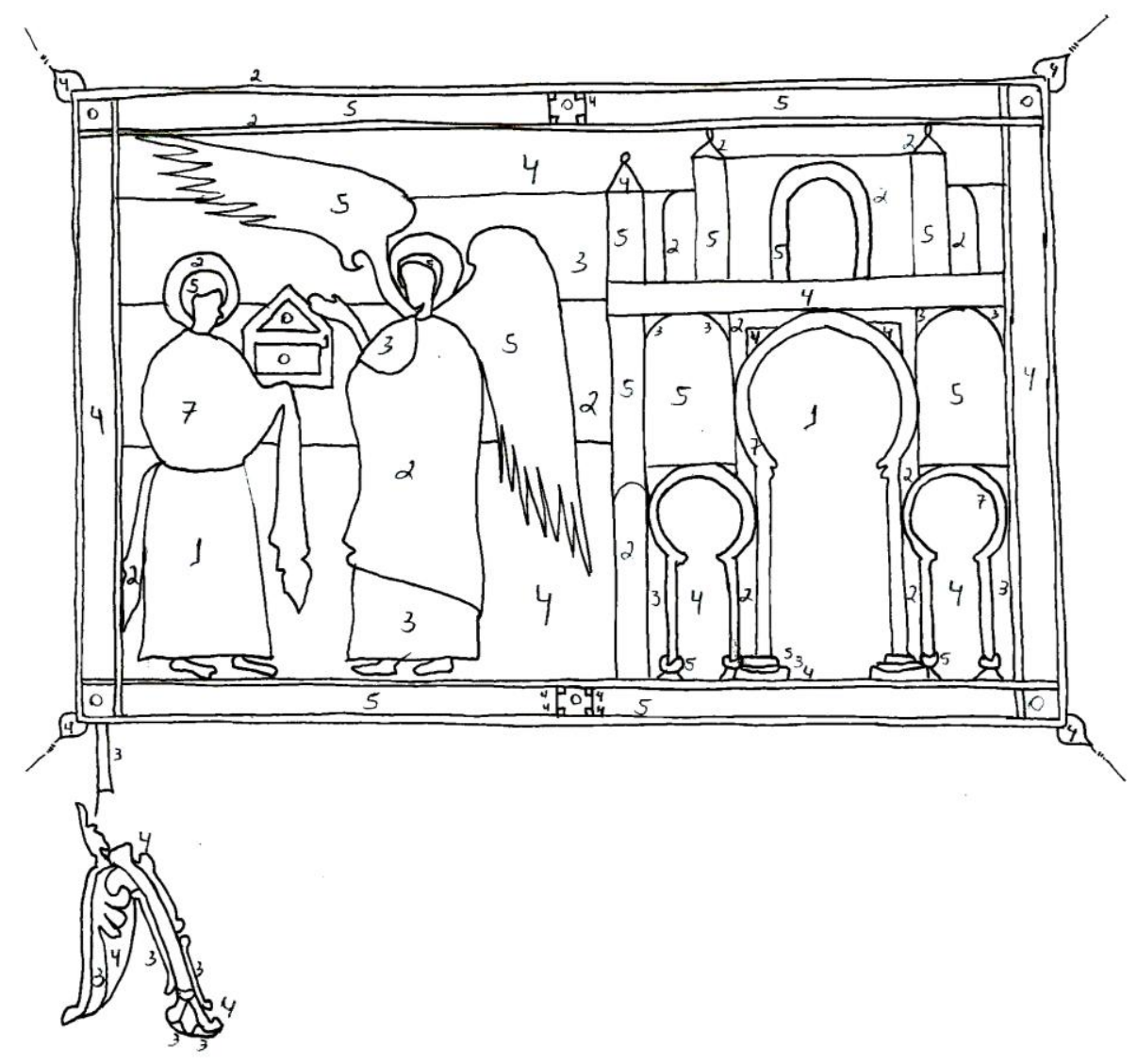

Figura 28. Esquema de cores, f. 92

Fonte: Elaborado pela autora 

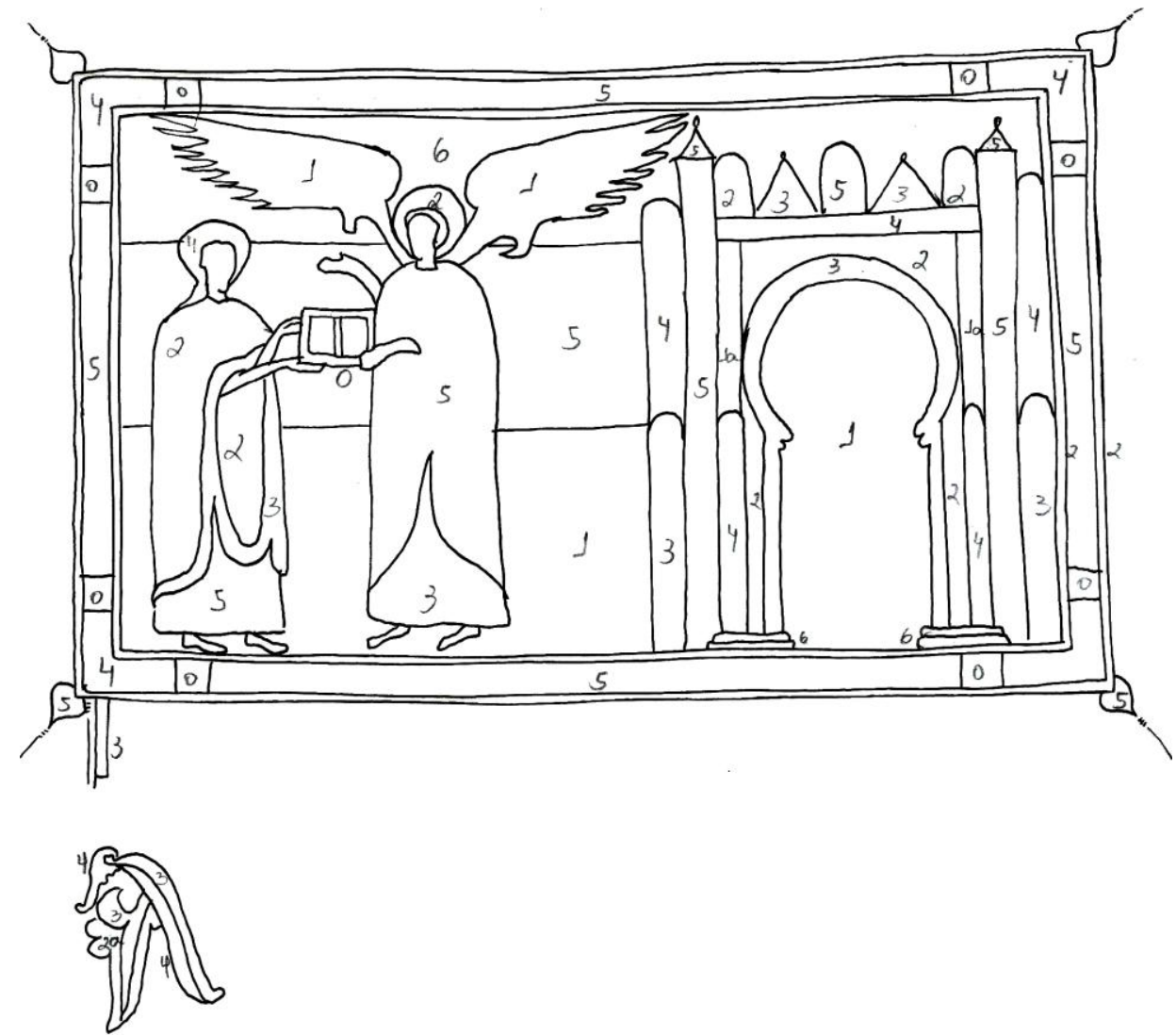

Figura 29. Esquema de cores, f. 96

Fonte: Elaborado pela autora

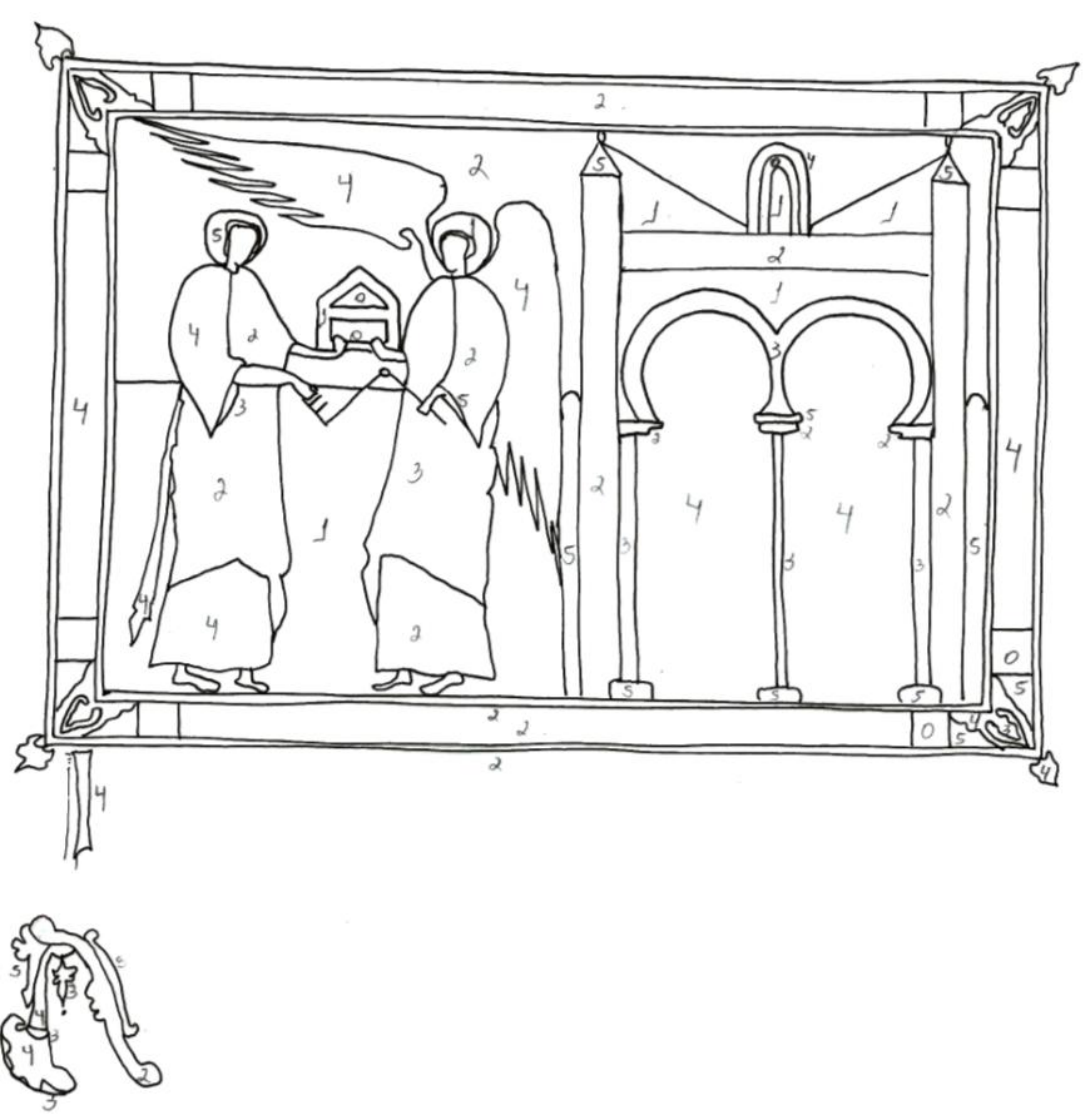

Figura 30. Esquema de cores, f. 100v

Fonte: Elaborado pela autora 


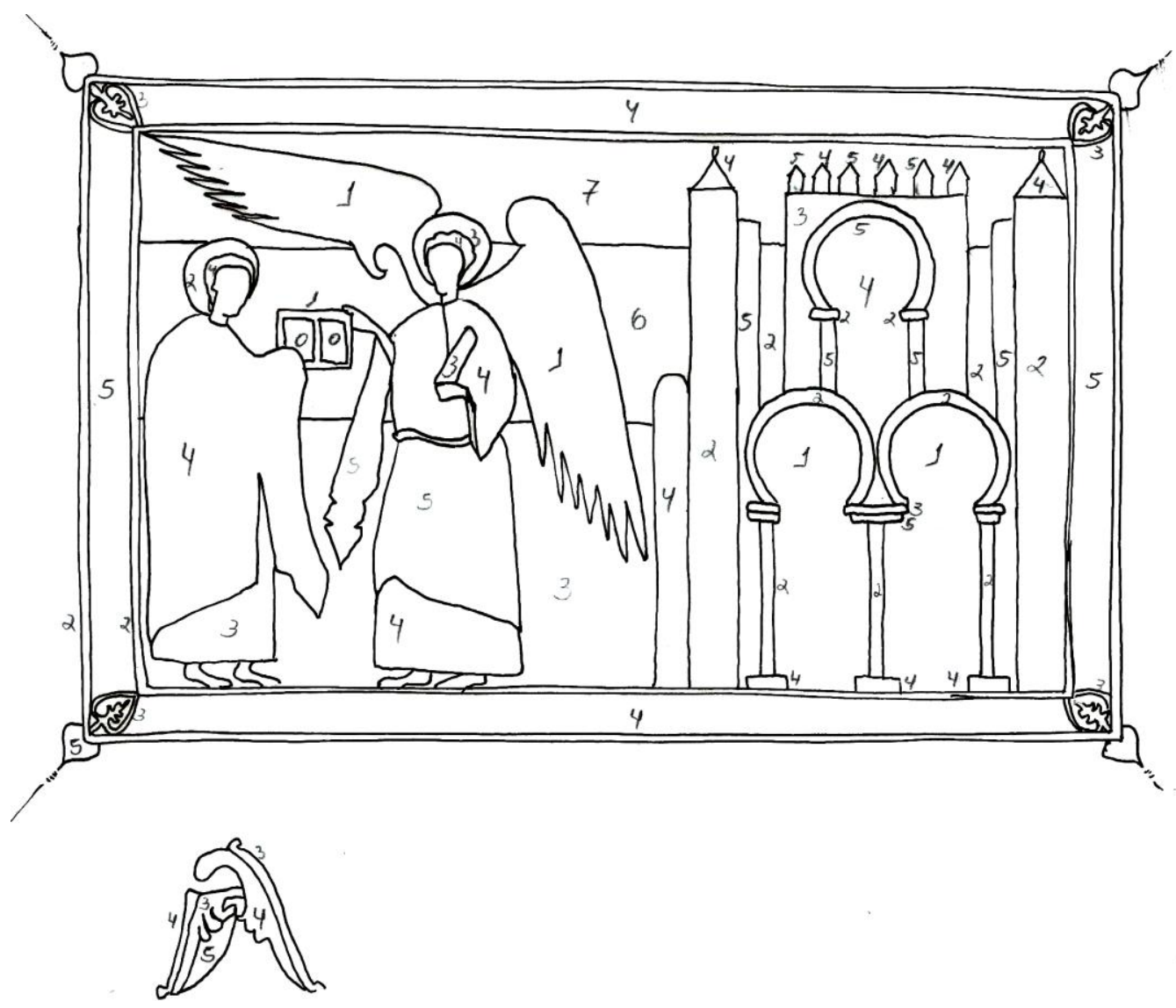

Figura 31. Esquema de cores, f. 106v

Fonte: Elaborado pela autora

Depois de identificadas as cores, façamos alguns comparativos pontuais quanto ao uso nas bandas de cor do campo:

\begin{tabular}{|c|c|c|c|c|}
\hline Fólio & $1^{\mathrm{a}}$ banda & $2^{\mathrm{a}}$ banda & $3^{\mathrm{a}}$ banda & $4^{\mathrm{a}}$ banda \\
\hline 78 & 2 & 5 & 3 & \\
\hline $82 \mathrm{v}$ & 1 & 5 & 4 & \\
\hline $87 \mathrm{v}$ & 5 & 2 & 3 & \\
\hline 92 & 4 & 3 & 2 & 4 \\
\hline 96 & 6 & 5 & 1 & \\
\hline $100 \mathrm{v}$ & 2 & 1 & & \\
\hline $106 \mathrm{v}$ & 7 & 6 & 3 & \\
\hline
\end{tabular}

Quadro 3. Varietas. Bandas de cor.

Fonte: Elaborado pela autora

Observamos que, nesta série, há uma predominância do uso das cores 2, 3 e 5 (tons vermelhos, amarelos e violetas). Na aplicação dos princípios de Bolman, apesar de não tratarmos de uma construção dentro de uma só imagem, encontraríamos, entre os ff. 78 e 87v, um misto de repetição espelhada ao longo de uma diagonal e uma repetição linear: 


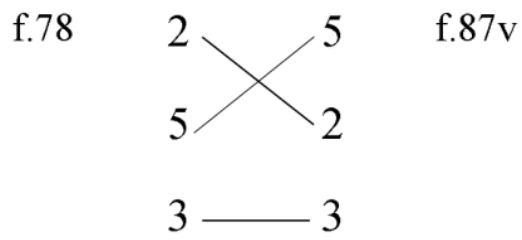

E no f.92, identificamos elementos que enquadram um padrão: $4 \quad 324$.

Quanto ao livro que João porta, observamos que há três diferentes formas de apresentação, as quais seguem a seguinte ordem cromática:

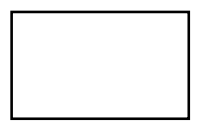

A

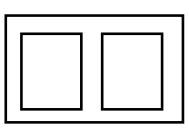

$\mathrm{A}^{\prime}$

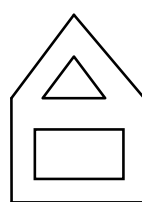

B

\begin{tabular}{|c|c|c|c|c|}
\hline Fólio & $\begin{array}{c}\text { Cor externa } \\
\text { do livro }\end{array}$ & $\begin{array}{c}\text { Cor interna } \\
\text { do livro }\end{array}$ & $\begin{array}{c}\text { Formato do } \\
\text { livro }\end{array}$ & $\begin{array}{c}\text { Presença de } \\
\text { outro elemento }\end{array}$ \\
\hline 78 & 0 & 0 & $\mathrm{~A}$ & Rolo \\
\hline $82 \mathrm{v}$ & 0 & 0 & $\mathrm{~B}$ & \\
\hline $87 \mathrm{v}$ & 0 & 0 & $\mathrm{~A}^{\prime}$ & Rolo \\
\hline 92 & 0 & 1 & $\mathrm{~B}^{\prime}$ & \\
\hline 96 & 0 & 0 & $\mathrm{~A}^{\prime}$ & \\
\hline $100 \mathrm{v}$ & 0 & 1 & $\mathrm{~B}^{\prime}$ & Chave \\
\hline $106 \mathrm{v}$ & 0 & 1 & $\mathrm{~A}^{\prime}$ & Rolo \\
\hline
\end{tabular}

Quadro 4. Varietas. Livros.

Fonte: Elaborado pela autora

O "outro elemento", do quadro 4, refere-se a quando o anjo porta um rolo ou, no caso da imagem de f. 100v, a chave, a mesma chave articulada que aparece no f.46v. Também observamos algumas repetições de cor entre a cor da asa do anjo e o interior da igreja - ff. 78 e $100 \mathrm{v}$ 


\begin{tabular}{|c|c|c|}
\hline Fólios & Cor das asas & Interior da igreja \\
\hline 78 & 1 & 1 \\
\hline $82 \mathrm{v}$ & 4 & 5 \\
\hline $87 \mathrm{v}$ & 2 & $3-1-1$ \\
\hline 92 & 5 & 1 \\
\hline 96 & 1 & $4-1-4$ \\
\hline $100 \mathrm{v}$ & 4 & $4-4$ \\
\hline $106 \mathrm{v}$ & 1 & $4-1-1$ \\
\hline
\end{tabular}

Quadro 5. Varietas. Asas do anjo e interior da igreja. Fonte: Elaborado pela autora

Além disso, ao observarmos as bordas das imagens, todas são formadas por linhas periféricas de cor vermelha, em acordo com a predominância, no Beatus de Facundus.

Não vamos nos estender em maiores explicações sobre os quadros, pois o ponto a que queremos chegar não é quantitativo. Como parte do processo de pesquisa, os esquemas e as foram úteis para evidenciar possíveis relações que poderiam ser construídas a partir deles. Mas os esquemas e os quadros, sozinhos, são estatísticos, medições quantitativas que identificam a variedade cromática, mas não a significam. As cores não significam se elas são isoladas. Quando isolamos as cores e as substituímos por números, ou letras, a imagem desaparece. Podemos encontrar princípios de ordenação das cores, jogos que aumentam a variedade cromática, mas sem a cor, sem o objeto, perdemos a imagem.

O que justifica esse tipo de quadro é a reunião das análises quantitativa e qualitativa. A análise qualitativa considera a localização dessa cor dentro de uma imagem ou dentro de uma série de imagens, e a quantitativa fala da variedade cromática. No Beatus de Facundus, não encontramos uma imagem monocromática, há uma exploração da varietas que nos leva, nas análises, a partirmos da variedade (quantitativo) para chegarmos à funcionalidade (qualitativo das cores). ${ }^{292}$

\footnotetext{
${ }^{292}$ Apesar de nos Beati a variedade cromática ser um elemento de apreciação estética, há produções em que o uso da cor pode pautar-se em outras questões, como no uso da grisalha (grisaille). Trata-se de uma técnica pictórica em que se utiliza apenas uma cor, geralmente cinza ou castanho (equivalente ao sépia, na fotografia), que é desdobrada em diversos valores tonais. Essa técnica foi muito utilizada no século XIV e XV, sobretudo em pinturas, iluminuras e vitrais. O uso é monocromático, mas o resultado é uma imagem em variedade de tons. Os motivos para o uso também podem ser variados e devem ser pensados dentro da própria imagem, em seu funcionamento. Podemos citar a possível referência a uma aproximação às figuras escultóricas, assim como pode ser usada para destacar elementos de uma narrativa que podem ser de outra ordem, como para diferenciar as narrativas interna e externa de um díptico. Muitos artistas utilizaram essa técnica, como Giotto, Jan van Eyck, Rogier van der Weyden, Hieronymus Bosch, entre outros. DALARUN, Jacques (dir.). Le Moyen Âge en lumière: Manuscrits enluminés des bibliothèques de France. Paris: Fayard, 2002. Ainda encontramos outras imagens que fazem uso de cores pontuais segundo uma lógica própria, como a imagem que figura os vícios e as virtudes no f. 163 do manuscrito BNF Lat. 2077, do mosteiro beneditino de Moissac (Quercy, França), em que o uso da cor em pequenas porções na imagem pauta-se como uma apresentação de poder. Sobre o uso da cor nessa
} 
Em uma série tão bem fechada como esta, com reduzidas variações de composição, não conseguimos observar com clareza as funcionalidades que as cores assumem nas imagens, além de seu papel ornamental como varietas.

Se este era um caminho de estreita saída, por que o tomamos? Por que acrescentar ao trabalho uma análise que se conclui no próprio argumento de não-conclusão? Porque faz parte do processo de pesquisa compreender as limitações dos esquemas e das ferramentas que usamos. Elas podem ser úteis para um determinado fim, mas nem sempre serão para todo tipo de aplicação. Quando lidamos com a formação de padrões de cor e o diálogo espacial entre as cores, o esquema é um ótimo recurso. Mas se não soubermos que as cores 1, 2 e 4 (azul, vermelha e preta azulada) são as cores mais utilizadas para figurar Cristo no manuscrito, de que adiantaria pensar que as asas dos anjos, nessa série, são figuradas em 1, 2 e 4, além de uma imagem que utiliza a cor 5 (violeta), a imagem do f. 92, aquela que faz a cisão das 6 imagens em dois conjuntos de três [1-4-2/5/ 1-4-1]. E que é nessa imagem, do f. 92, as faixas de fundo são divididas em 4, e não em 3, como a maioria da série. O f. 92 também é uma exceção na figuração das auréolas e dos cabelos de João e do anjo. Apenas nos ff. 87v, 92 e 96 utiliza-se as cores 2 e 4 para auréolas, nos outros fólios não há repetição de combinações. Nos ff. 87v e 92, João possui auréola na cor 2 e o anjo na cor 4. No f. 96 a ordem é espelhada: João com auréola na cor 4 e o anjo na cor 2 . A exceção a que nos referimos é feita pela forma e pela cor dos cabelos de João e do anjo de Tiatira, ambos na cor 5 com linhas pretas, e não um bloco preto, como nas outras imagens da série. Essa é, provavelmente, uma referência ao Cristo que aparece no f. 46 (Ap.1, 10-20), visto que o texto do Ap. 2, 18-20, a que se refere à imagem do f. 92, torna presente o Cristo daquela passagem através da carta que envia a Tiatira. "Escreve ao anjo de Tiatira: Assim disse o Filho de Deus, cujos olhos são como chama de fogo e cujos pés parecem de metal precioso do Líbano [...]". ${ }^{293}$

Os padrões e as lógicas composicionais que podem ser observadas só funcionam quando lhe devolvemos a imagem, quando permitimos que a cor exista e trabalhe dentro de seu contexto, dentro da imagem, dentro do texto. Não esqueçamos que, aqui, analisamos imagens que já se encontram "acabadas", em que cada cor trabalha em conjunto sem que

imagem, ver PEREIRA, Maria Cristina C. L. Da queda para o alto: vícios e virtude em uma miniatura românica. In: FOGELMAN, Patricia (Org.). Actas del I Simposio sobre Religiosidad, Cultura y poder. Universidad de Buenos Aires, 22 y 23 de junio de 2006. Buenos Aires: GERE, 2006.

${ }^{293}$ CAMPO HERNÁNDEZ, Alberto del; FREEMAN, Leslie G.; GONZÁLEZ ECHEGARAY, Joaquín (ed.). Beato de Liébana. Obras completas y complementarias. Edição bilíngue do latim ao castelhano. Madrid: Biblioteca de Autores Cristianos, 2004, v. 1, p. 218-219. 
possamos proibi-las de trabalhar. A percepção do corpo de uma cor é influenciada "retinicamente" pelo seu entorno. Vemos as cores próximas às outras, modificadas visualmente pelas cores vizinhas. Ao observarmos dois grupos de círculos concêntricos, em que o círculo interno é de mesma cor nos dois grupos e o círculo externo é de cor variada, a cor interna, não será percebida da mesma forma nos dos conjuntos, pois ela reage ao entorno. Essa noção de contaminação também influi no trabalho classificatório das cores do manuscrito. Quando ficamos em dúvida, recorremos a uma ferramenta simples de isolamento de cor, um pequeno quadrado de molde vazado que só mostra o que queremos ver, de modo isolado. Às vezes é necessário isolar uma cor para compreendermos que não podemos isolála.

As nomeações das cores são abrangentes para não nos estendermos infinitamente nas diferenciações. Esses são limites de um esquema. E temos de admitir que essas numerações foram vistas e revistas várias vezes e, até o momento, não estamos satisfeitos com o resultado. Sabemos que permitir ao azul ter uma pequena variação para "1a", deveria permitir que uma variação de cor na estrutura da igreja do f. 78 fosse nomeada como "2a". Mas, assim, então todos os números começariam a se multiplicar e ainda não estaríamos satisfeitos, pois a imagem medieval não consegue ser pensada fora de seu próprio corpo. O esquema retira da imagem medieval seu poder de ser uma imagem-objeto, uma imago, uma figura, e recorta toda a amplitude de questões que ela abarca, para reduzi-la a lógicas matemáticas de organizações estruturais. Talvez os números, ou letras isoladas, as fórmulas e as medições quantitativas não sejam as melhores formas de se pensar o trabalho da cor-ornamento em uma imagem medieval, pois toda vez que olhamos a imagem, as variáveis mudam.

Cores e padrões podem trabalhar juntos, mas eles trabalham de modo ornamental. Isto significa que os princípios de variedade cromática, bem como as funções simbólica e iconográfica da cor, exercem poder ornamental no modo como as cores são usadas pela imagem.

O propósito não é, por assim dizer, de buscar pensar a cor, coisa vã, mas de mostrar como a imagem pensa em cores; a cor se vê e se experimenta, e se alguma coisa nela é pensável, não é o que ela é, mas o que ela faz; e ela pode sem dúvida fazer sentido, mas ela está longe de se reduzir a essa função. ${ }^{294}$

\footnotetext{
${ }^{294}$ BONNE, Jean-Claude. Penser en couleur: à propôs d'une apocalyptique du X siècle. In: SCHMITT, JeanClaude; HÜLSEN-ESCH, Andrea von (Org). Die Methodik der bildinterpretation / Les méthodes de l'interpretation de l'image. Deutsch-französische Kolloquium 1998-2000. Göttingen: Max-Planck Institut für Geschichte, 2002, v.2, p.361-362, tradução nossa.
} 
Quando a imagem é reduzida a um esquema de identificação de cores, anulamos o trabalho da cor junto do entorno e não permitimos que a imagem "pense em cores". O esquema mais isola a cor do que a coloca dentro da imagem para trabalhar. Essa redução da cor, em suas localização e articulação com outras cores, de modo matemático e em busca de padrões, não permite que a variação cromática trabalhe junto dos outros elementos de composição. Dissemos, acima, que as imagens da série analisada esquematicamente têm variações reduzidas na composição, mas isso não é o que acontece quando vemos a composição fora do esquema. As variações aparecem, sobretudo, nas estruturas arquiteturais das igrejas, nos gestos das mãos de João e dos anjos, nas posições das asas dos anjos, nas composições ornamentais das bordas e nas composições das letras capitulares. A variação cromática não está isolada da variação da forma e da presença das cores no objeto. A cor trabalha como ornamento e, por esse motivo, não há trabalho se não houver o que e por que ornamentar.

As cores, como outros ornamentos, fazem parte, segundo Bonne, de uma operação de marcações estéticas (opération du marquage) ${ }^{295}$ que tomam posse da imagem de modo decente (decet) e a modalizam como uma ferramenta tonal,

O ornamental frequentemente opera como um "mediador" que permite modular o tema central com frisos, arquiteturas, jogos formais que fazem ao mesmo tempo eco com as tensões iconográficas e dá-lhes como um acompanhamento musical (como as ondulações solo de Nohant-Vicq). Assim é definida a tonalidade expressiva de uma ação, de uma figura ou de um conjunto. ${ }^{296}$

Através da operação de marcas, o ornamento interfere esteticamente na imagem e passa a atuar como um intensificador, um modulador que cria e intensifica diferenças e tonalidades de algo que é expresso. Por analogia, pode-se aproximar o sistema modulador ao da música tonal, o qual apresenta uma hierarquia nas notas utilizadas para compor-se ao entorno de uma nota principal. Isto é, os diferentes graus de ornamentação de uma imagem criam modulações, intensidades e diferenciações hierárquicas entre elementos e imagens. Por meio do tratamento ornamental, uma imagem distingue-se hierarquicamente de outra.

\footnotetext{
295 BONNE, Jean-Claude. De l'ornemental dans l'art médiéval (VIIè - XIIè siècle): Le modele insulaire. In: SCHMITT, Jean-Claude; BASCHET, Jérôme (orgs). L'image: Fonctions et usages des images dans l'Occident médiéval. Paris: Le Léopard d'Or, 1996, p. 215.

${ }^{296}$ BONNE, Jean-Claude. De l'ornemental dans l'art médiéval (VIIè - XIIè siècle): Le modele insulaire. In: SCHMITT, Jean-Claude; BASCHET, Jérôme (orgs). L'image: Fonctions et usages des images dans l'Occident médiéval. Paris: Le Léopard d'Or, 1996, p. 219, tradução nossa.
} 
Desse modo, a cor-ornamento não opera segundo o que ela é, uma cor, mas como um acompanhamento que orquestra ${ }^{297}$ todo o conjunto da imagem e do manuscrito, que não exclui sua relação com a iconografia ou com o símbolo, nem se reduz a uma ideia de variedade cromática que celebra a imagem. A celebração é a primeira função, mas a cor continua a trabalhar.

O trabalho modulador da cor-ornamento pode ser observado especialmente na comparação entre três miniaturas do Beatus de Facundus, entre os f. 70v (Dan 7), f. 191v (Ap. 13, 1-8) e f. 287 (Dan 7) (Figura 32). Há, nessas miniaturas, uma relação textual entre elas, pois a besta figurada no f. 191v é, segundo Beato de Liébana, a quarta besta do livro de Daniel (Dan 7, 7), que aparece tanto no f. 70v, quanto no f. 287. "Assim devemos entender a besta, que surge do abismo, que surge do mar, que surge da terra: todas são a mesma besta. [...] Esta é a besta terrível que em Daniel se descreve [...]". ${ }^{298}$ A serpente (ou dragão, nas traduções bíblicas atuais), adorada por aqueles que seguem a besta, no f. 191v, é a mesmo do capítulo anterior, Ap. 12, 1-18 (ff. 186v-187), presente na figuração da Mulher vestida de sol. A figuração da serpente é muito similar, principalmente quanto ao corpo ornamentado, mas, no f. 191v, a serpente não possui os dez chifres e as sete diademas. Apesar das indicações textuais de descrição das bestas serem próximas, as imagens são marcadas pelo ornamento em diferentes graus.

\footnotetext{
${ }^{297}$ BONNE, Jean-Claude. Repenser l'ornement, repenser l'art médiéval. In: Le rôle de l'ornement dans la peinture murale du Moyen Âge. Actes du Colloque International, Saint-Lizier, 1-4 juin 1995. Poitiers: Université de Poitiers, 1997, p.218.

${ }^{298}$ CAMPO HERNÁNDEZ, Alberto del; FREEMAN, Leslie G.; GONZÁLEZ ECHEGARAY, Joaquín (ed.). Beato de Liébana. Obras completas y complementarias. Edição bilíngue do latim ao castelhano. Madrid: Biblioteca de Autores Cristianos, 2004, v. 1, p. 470-471.
} 

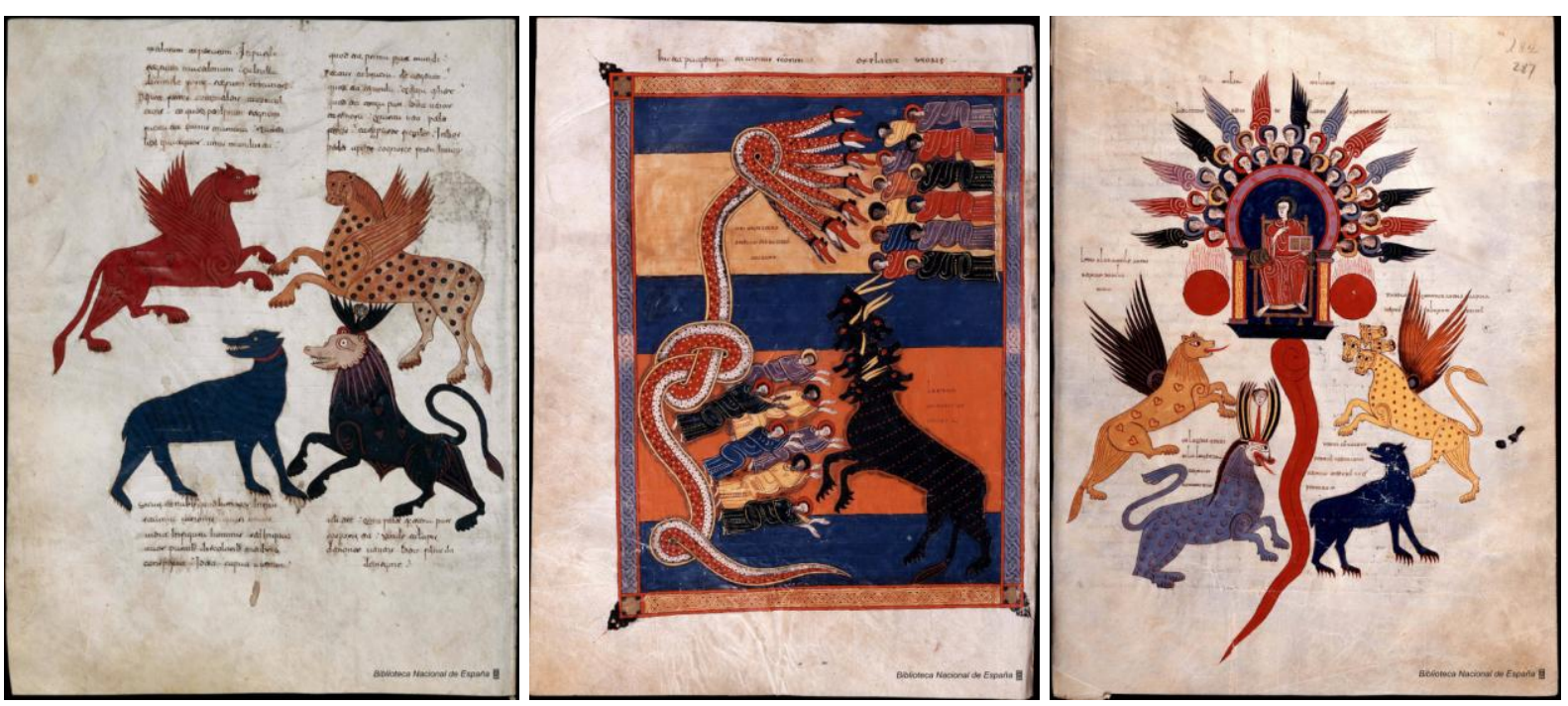

Figura 32. Beatus de Facundus, ff. 70v, 191v, 287.

Fonte: www.bne.es
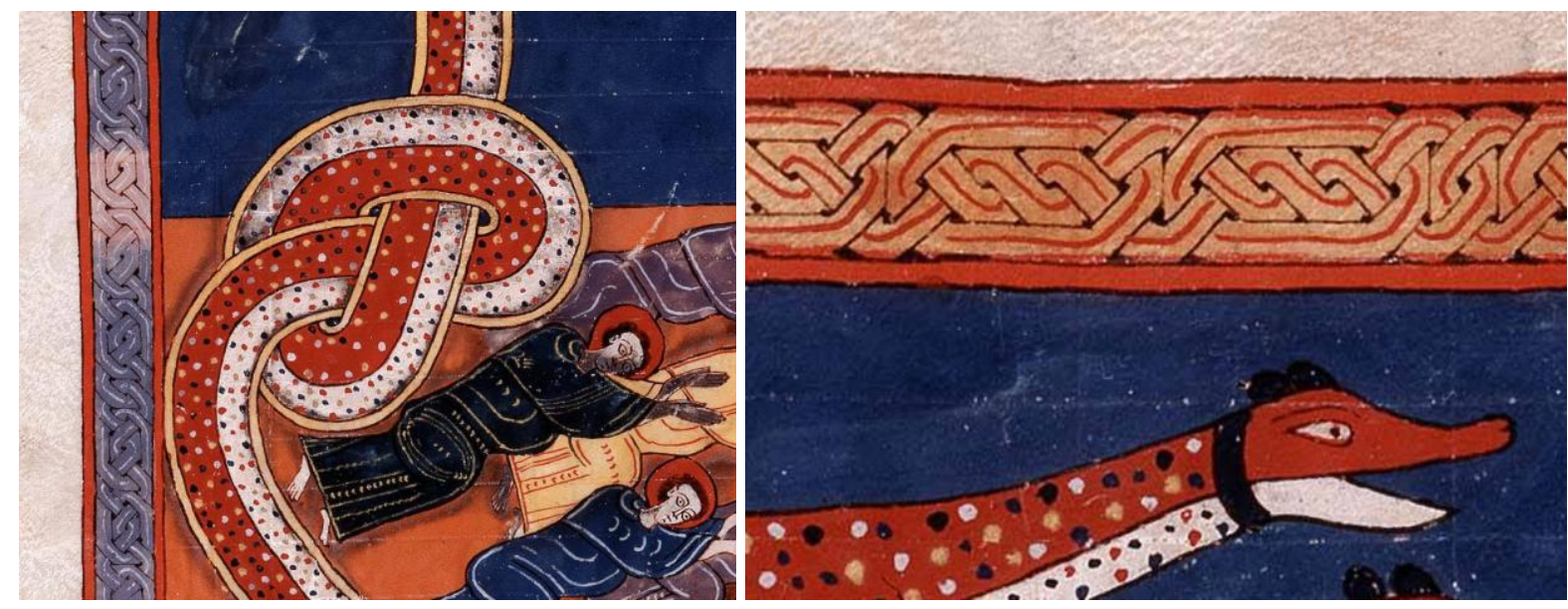

Figura 33. Beatus de Facundus, f. 191v, detalhes de ornamento.

Fonte: www.bne.es (recorte da autora)

No f. 191v, a imagem possui borda ornamentada, uso de ouro e maior profusão de cores explorada nas bandas de cor e nas vestes daqueles que seguem a besta e adoram a serpente. A borda, junta do campo em bandas de cor, distingue o lugar da imagem dentro do fólio e cria tensões que distanciam a imagem da besta do Ap 12 da figuração da besta do livro de Daniel.

[...] a ornamentação põe em valor e, nesse sentido, estetiza pelo menos algumas das propriedades plásticas do objeto-suporte. Lidamos aqui com um funcionamento que excede originalmente todas as funções que ele poderia suportar já que encontra primeiro seu fim nele mesmo - tal seria a liberdade, ou finalidade sem fim, inerente ao ato ornamental; o agente se efetua (ou é efetuado) pela operação mesma de 
marcação (ou facilitação) que o liga necessariamente a um suporte ou a um substrato. A ornamentalidade que resulta seria, pois, constituída de todas as espécies de valores formais colocadas em jogo neste ato que é também uma troca ou uma conjunção dialética entre as marcas (de um agente) e seu campo de inscrição [...]. ${ }^{299}$

As marcas ornamentais, empregadas nas imagens, assinalam o diálogo com o objeto. Elas modulam as imagens segundo a importância delas dentro do manuscrito. Modular é diferenciar, criar intensidades que marcam e que destacam um objeto (imagem) dentro de um conjunto. $\mathrm{O}$ emprego de maior ou menor grau de ornamentação entre essas imagens relacionase mais com as localizações das imagens no manuscrito e com os textos dos quais se originam, se do Apocalipse ou de Daniel, que com a narrativa interna das imagens. A imagem de f. 191v relaciona-se ao texto do Apocalipse e encontra-se dentro do Livro VI do Comentário ao Apocalipse. A imagem do f. 287 relaciona-se com o texto de Daniel e encontra-se dentro do Comentário ao livro de Daniel, por São Jerônimo. Trata-se da revelação do juízo de Deus e das quatro bestas que surgem do mar, dada a Daniel em sonho (Dn 7). A figuração desta imagem, que ocupa uma página inteira, segue a composição das outras imagens do Comentário ao Livro de Daniel: inscritas diretamente na superfície da página, sem o emprego de borda e bandas de cor, exceto por uma porção da imagem que figura o Ancião, que é Deus, sentado em seu trono rodeado pelos santos que são convocados para julgar junto Dele. O Ancião já havia aparecido nas imagens no f. 46 (Ap. 1, 10-20), mas há um tratamento ornamental muito diferenciado que distancia as duas figurações. Cria-se, com isso, um jogo de hierarquias nas miniaturas da figuração do Ancião, diferenciadas, sobretudo, pelo tratamento ornamental da cabeça, que no livro de Daniel não aparece com os cabelos brancos e é semelhante aos outros personagens da cena, diferente do Ancião do f. 46. Dentro da imagem do f. 287, as marcas estéticas criam uma hierarquia entre o espaço das bestas e o espaço celeste destinado ao Ancião.

Os textos do Apocalipse e de Daniel evocam certas propriedades materiais, plásticas, que são suscetíveis de serem marcadas por índices ornamentais que as qualificam hierarquicamente sob um modo estético próprio. Como um modulador, as marcas ornamentais fortalecem a hierarquia interna às imagens do manuscrito, quanto ao seu grau de relevância para o conjunto. Por ser o Beatus uma obra dedicada ao livro do Apocalipse, o ornamento reforça a distinção entre as imagens apocalípticas e aquelas relacionadas ao Livro de Daniel

\footnotetext{
${ }^{299}$ BONNE, Jean-Claude. De l'ornemental dans l'art médiéval (VIIè - XIIè siècle): Le modele insulaire. In: SCHMITT, Jean-Claude; BASCHET, Jérôme (orgs). L'image: Fonctions et usages des images dans l'Occident médiéval. Paris: Le Léopard d'Or, 1996, p. 215-216.
} 
ou aos comentários de Beato de Liébana. A distinção no tratamento ornamental, efetuada pelo papel modulador, atua intimamente em consonância com o status da imagem no conjunto do manuscrito ao intensificar as miniaturas que possuem um status qualitativo superior, independente da parte em que se encontram no conjunto. Deste modo, a imagem do f. 70v, que se encontra no prólogo do livro II do Comentário ao Apocalipse, não segue a mesma lógica composicional das imagens que se relacionam diretamente ao livro do Apocalipse, mas aproxima-se do tratamento dado às imagens do Comentário ao livro de Daniel, dispostas diretamente sobre a página, sem borda nem banda de cor.

Além das quatro bestas do f. 70v, observamos que outras imagens, localizadas dentro dos doze livro do Comentário ao Apocalipse, possuem uma economia imagética semelhante: a estátua com cabeça de ouro do livro de Daniel (f. 71), que é descrita em conjunto com as quatro bestas, no prólogo do livro II; a Palmeira dos justos (f. 160), incluída no Livro IV quando Beato de Liébana trata, na explanatio, dos 144 mil marcados de Israel, como semelhança ao justo; a imagem da Raposa e o Galo (f. 197), que aparece em uma explanatio no Livro VI, a propósito da passagem de São Lucas (Lc 9,58) cujo comentário compara a raposa, animal esperto, com os hereges; e, por fim, a imagem da Queda da Babilônia (ff. 233v-234) que, diferente das outras imagens aqui citadas, não se refere ao livro de Daniel, nem pertence a explanatio de Beato de Liébana (Figura 34). Trata-se de uma imagem referente ao livro do Apocalipse, disposta como as ouras imagens do Comentário ao Apocalipse, entre a storia e a explanatio. Esta é a única imagem apocalíptica que não possui borda e campo com bandas de cor. ${ }^{300} \mathrm{O}$ diferenciado tratamento ornamental da imagem a aproxima das imagens originadas do livro de Daniel e do Comentário ao livro de Daniel, por São Jerônimo. A Babilônia aparece nos comentários de Beato de Liébana sobre as bestas (f. 70v), em que a primeira besta seria o reino da Babilônia. ${ }^{301}$ No Comentário ao livro de Daniel, encontramos uma figuração muito semelhante a esta da Babilônia, nos ff.268v-269, nos quais figura o cerco a Jerusalém, imposto por Nabucodonosor, rei da Babilônia (Figura 35). As duas imagens, da Queda da Babilônia e do Cerco a Jerusalém, ocupam dois fólios. No primeiro,

\footnotetext{
${ }^{300}$ A imagem referente ao Ap. 10 e Ap. 11, 1-2, que ocupa os ff. 176v-177, possui, no f. 177, uma composição sem borda e campo de bandas de cor, mas essa composição não segue a mesma lógica moduladora aqui proposta. Os motivos para tal figuração não se referem a um jogo de localização textual ou de operação de marcas estéticas que criam hierarquias, mas, sobretudo, em relações de ressonância figurativa, em que a figuração do rio é que define a configuração da página.

${ }^{301}$ CAMPO HERNÁNDEZ, Alberto del; FREEMAN, Leslie G.; GONZÁLEZ ECHEGARAY, Joaquín (ed.). Beato de Liébana. Obras completas y complementarias. Edição bilíngue do latim ao castelhano. Madrid: Biblioteca de Autores Cristianos, 2004, v. 1, p. 156-157.
} 
figura o conjunto arquitetônico das cidades e a narrativa que se desenrola ao entorno delas, e, no segundo fólio, personagens que interagem com a cena anterior, à distância. No caso na Queda da Babilônia, essa separação em dois blocos é referida pelo próprio texto, em que aqueles que lamentam o incêndio da Babilônia e sua destruição são postados à distância. Essa distância é reforçada pelo próprio "miolo" do livro, na posse do suporte pela imagem. A passagem de Daniel 1, 1, que figura o Cerco a Jerusalém, não faz referência a essa distância, mas aqueles que atacam Jerusalém, que agem sobre a cidade, colocam-se também apartados dela.

As aproximações e distanciações criadas pelo poder modulador, sobretudo através das cores, fazem com que a dimensão estética do ornamento, nas noções de decus e decor, celebre a imagem ao mesmo tempo em que crie diferentes intensidades entre as imagens e tensões com a percepção delas dentro do conjunto do manuscrito.

A intensidade de variação e profusão das cores não serve apenas no sentido de apreciação estética de varietas, ela funciona em diálogo com a estruturação do manuscrito e da própria imagem e está a serviço de um poder de orquestração. Esse poder de orquestração é "[...] capaz de articular vários meios, independente das suas diferenças de conteúdo", ${ }^{302}$ pois o ornamento não se reduz ao sentido, está em tensão com o abstrato, com o ato, que o permite afetar toda a imagem e o objeto no qual se inscreve, no qual impõe suas marcas. Nesse sentido, o ornamento funda lugares, qualifica o lugar, ou lugares, como o celeste e o terrestre, e gerencia o diálogo entre as partes que marca.

\footnotetext{
${ }^{302}$ BONNE, Jean-Claude. Repenser l'ornement, repenser l'art médiéval. Actes du Colloque International: Le rôle de l'ornement dans la peinture murale du Moyen Âge. Saint-Lizier, 1-4 juin 1995. Poitiers: Université de Poitiers, 1997, p. 218.
} 


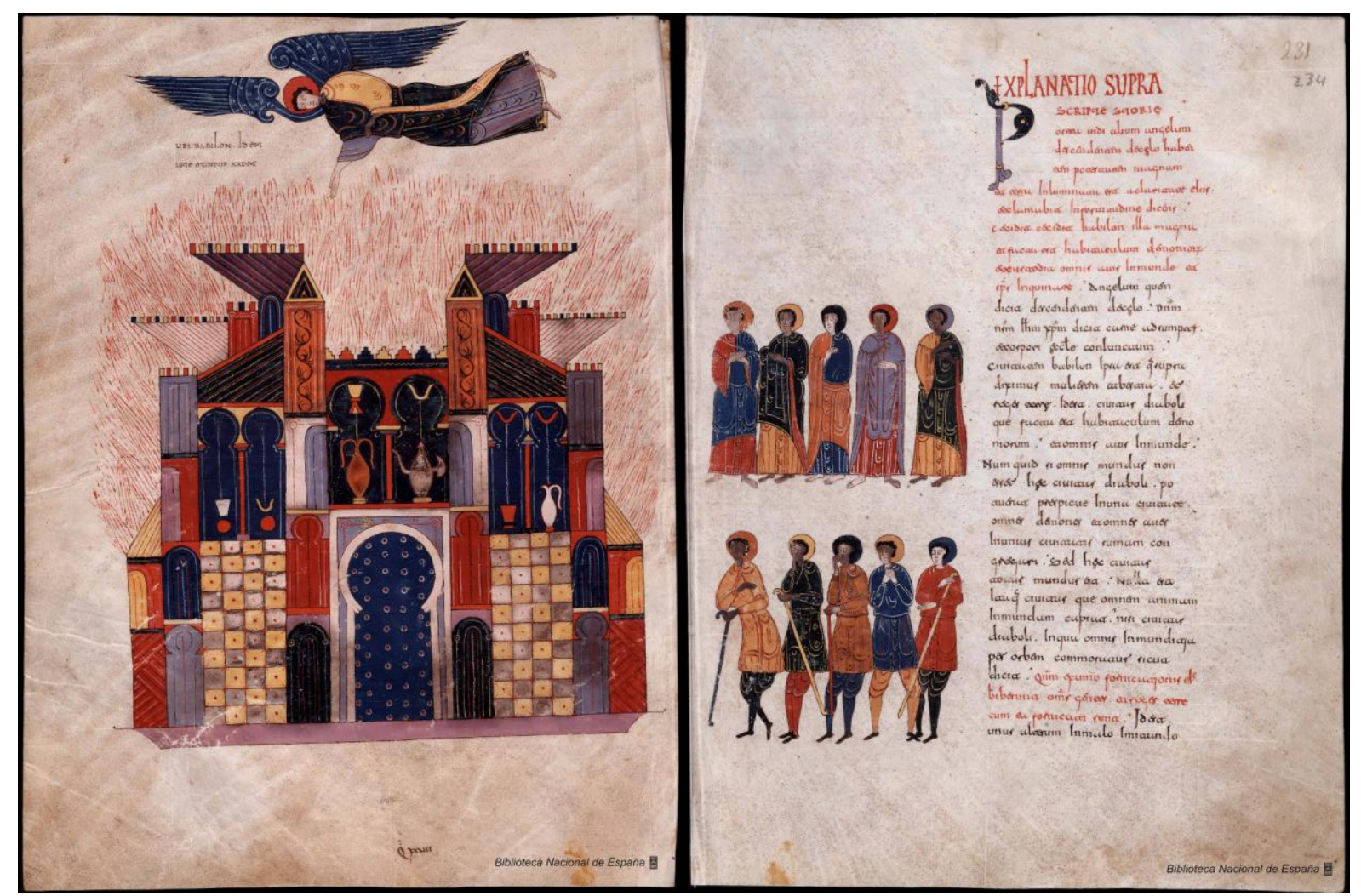

Figura 34. Beatus de Liébana, ff. 233v-234, Queda da Babilônia. Fonte: www.bne.es

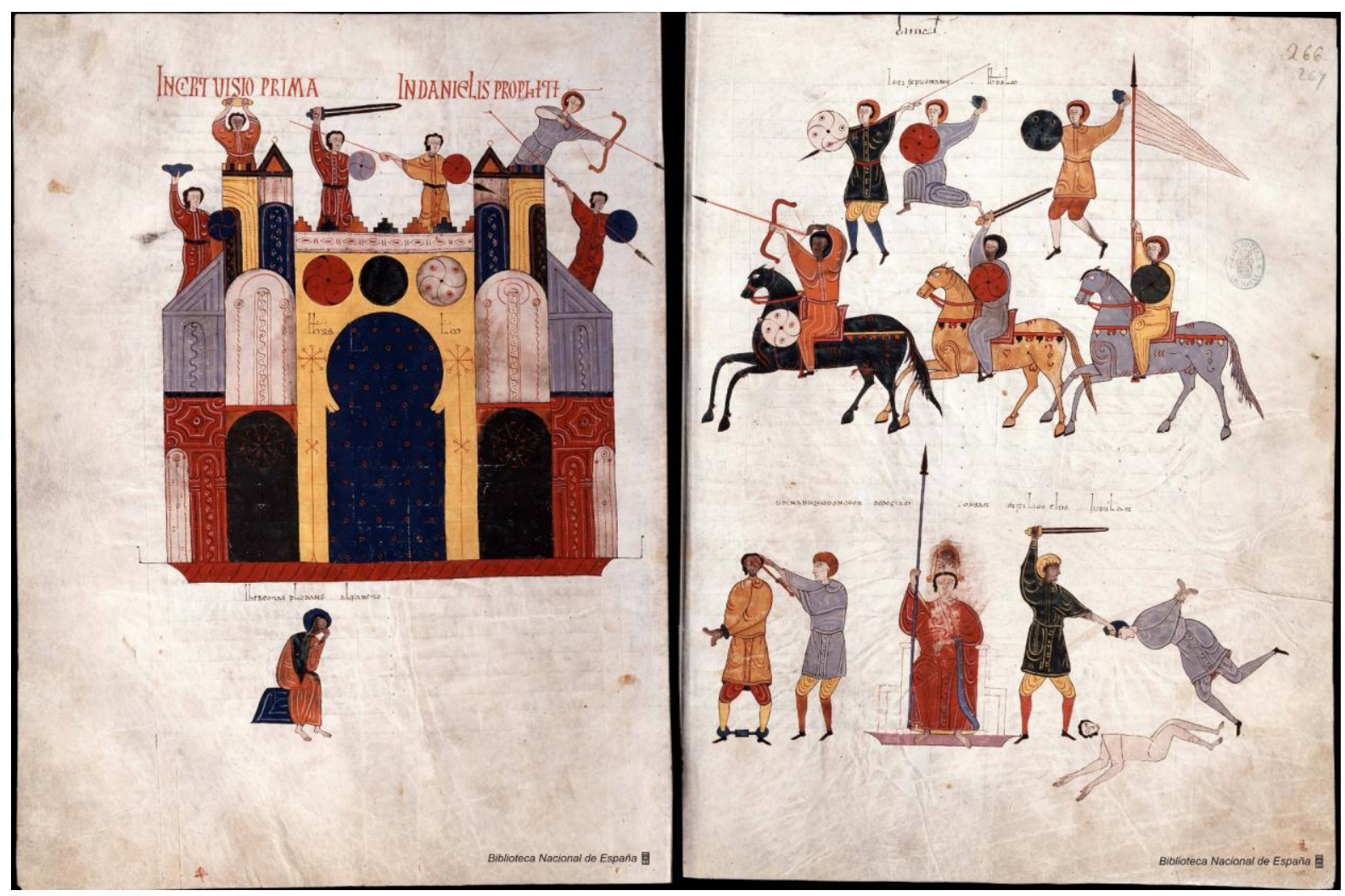

Figura 35. Beatus de Facundus, ff. 268v-269, Cerco a Jerusalém. Fonte: www.bne.es 


\title{
5 A ORQUESTRAÇÃO DO FIM DO MUNDO
}

"Quando abriu o sétimo selo, fez-se silêncio no céu". ${ }^{303}$

ou

"Quando o abrigo é seguro, a tempestade é boa". ${ }^{304}$

A preparação para o dia do Juízo Final e a salvação dos fieis está em eterno curso no Apocalipse. As palavras e as imagens do Beatus de Facundus não pertencem ao tempo. Os sete selos são abertos para que a história seja recontada em outras palavras pelas sete trombetas. A história é vista e escrita por João em sequências atemporais. O livro é iniciado por aquele que é o alfa monumental e o ômega em ouro do f.6, o Todo Poderoso do Ap. 1, 8, o mesmo que finaliza a obra no Ap. 22, 13, "Eu sou o Alfa e o Ômega, o primeiro e o último, o princípio e o fim." ${ }^{305}$ Storia, imagem e explanatio estão em constante diálogo para a formação de redes de recapitulações que atravessam o Cristo, saem e voltam a Ele e ao triunfo divino. Ir, voltar, folhear, circular, conectar, distanciar, abraçar, pensar, desviar, emocionar, figurar... são verbos guiados pelos tempos e lugares das imagens.

\begin{abstract}
Não só as figuras são provisórias, como são também a forma provisória de algo eterno e atemporal; apontam não só para o futuro concreto, mas também para algo que sempre existiu e existirá; apontam para algo que necessita de interpretação, que na verdade será preenchido no futuro concreto, mas que já está presente, preenchido pela providência divina, que não conhece diferenças de tempo. Esta dimensão eterna já está figurada nelas, que, desse modo, são ao mesmo tempo, uma realidade fragmentária provisória e uma realidade eterna velada. ${ }^{306}$
\end{abstract}

\footnotetext{
303 CAMPO HERNÁNDEZ, Alberto del; FREEMAN, Leslie G.; GONZÁLEZ ECHEGARAY, Joaquín (ed.). Beato de Liébana. Obras completas y complementarias. Edição bilíngue do latim ao castelhano. Madrid: Biblioteca de Autores Cristianos, 2004, v. 1, p. 404-405 (explanatio de Beato de Liébana sobre o sétimo selo).

${ }^{304}$ Henri Bosco citado por BACHELARD, Gaston. A poética do espaço. Tradução de Antônio da Costa Leal e Lídia do Valle Santos Leal. Rio de Janeiro: Eldorado Tijuca, 1989, p. 223.

305 CAMPO HERNÁNDEZ, Alberto del; FREEMAN, Leslie G.; GONZÁLEZ ECHEGARAY, Joaquín (ed.). Beato de Liébana. Obras completas y complementarias. Edição bilíngue do latim ao castelhano. Madrid: Biblioteca de Autores Cristianos, 2004, v. 1, p. 634-635.
}

${ }^{306}$ AUERBACH, Erich. Figura. São Paulo: Ática, 1997 (série Temas, v.62), p. 51. 
O apontar das figuras direciona-se para as visões de João, para as interpretações compiladas por Beato de Liébana, bem como para si mesmas, como parte do lugar em que a Revelação continua a acontecer. A imagem é um dispositivo que usa sua matéria para ocupar outros lugares além daquele do objeto concreto. Pergaminho, linha, cor, palavra, figura, exegese, todo tipo de ornamento é usado pela máquina para tornar o manuscrito uma figura presente, que serve a propósitos políticos, cultuais, rituais e simbólicos.

As marcas plásticas e cromáticas do ornamento trabalham em conjunto sobre a superfície de inscrição, sem que as propriedades plásticas do suporte sejam exibidas. Pensemos em quão trabalhosa é a produção de um pergaminho para receber uma imagem. Ele é raspado e esticado várias vezes, para que se torne o mais regular possível. Pensemos no esforço para fazer cada face do fólio encontrar sua semelhante (face de pelo com face de pelo e face de carne com face de carne), para que elas possam exercer um trabalho aproximado, sem distorções próprias da matéria. Não se pode confundir suporte e superfície de inscrição. Aquele é a matéria potencial deste. O suporte é uma superfície de inscrição potencialmente. Sua escolha já pressupõe uma adequação ao recebimento de signos, mas ele ainda é uma matéria bruta, mesmo quando inteiramente elaborado, como o pergaminho.

As figuras e as cores aparecem não para mostrar os capilares do manuscrito - não do mesmo modo como faz um artista que raspa a tela recém-pintada para mostrar a linha de que é feita. Nem mesmo pautam por uma "ultrapassagem" da sua superfície de inscrição, como fizeram os pintores e escultores hiperrealistas. As figuras e suas cores também não trabalham para abrir uma janela ilusionista, como aquela do Renascimento e de outras produções posteriores, a imagem medieval não é uma construção formal deformada que faria parte de uma jornada para a representação espacial ilusionista. ${ }^{307}$

Basta-nos observar como o termo "perspectiva inversa" ${ }^{308}$ parece inadequado quando colocado ao lado da perspectiva "normal". Como observa Panofsky, em "Perspectiva como

\footnotetext{
${ }^{307}$ Apesar das importantes contribuições de Erwin Panosfky para o estudo, sobretudo, da produção gótica, o autor pauta seu trabalho nessa longa jornada, em que cada passo que se dá em direção a perspectiva linear renascentista é uma pequena conquista para a imagem, como se fosse do desejo de toda imagem ser ilusionista e "real", independente a que realidade sirva. PANOFSKY, Erwin. A perspectiva como forma simbolica. Lisboa: Ed.70, 1993. Segundo Bonne, "Panofsky tenta assim fazer advirem os sistemas perspectivistas dos sistemas em que a ausência de perspectiva ou suas pretensas imperfeições são interpretadas como uma falta que pediria para ser corrigida, e em seguida ele vê a sucessão de sistemas com perspectiva como afirmação progressiva da construção exata". BONNE, Jean-Claude. Fond, surfaces, support. Panofsky et l'art roman. In: et al. Erwin Panofsky. Paris: Centre Georges Pompidou/Pandora, 1983, p. 120, traduzido por Eduardo H. Aubert.
}

308 BONNE, Jean-Claude. "Fond, surfaces, support. Panofsky et l'art roman". In: et al. Erwin

Panofsky. Paris: Centre Georges Pompidou/Pandora, 1983, p. 117-134. 
forma simbólica", ${ }^{309}$ a perspectiva "normal" supõe uma imagem criada a partir do ponto de vista de um observador localizado fora da imagem e, "normalmente", com um ponto de fuga único. Esta noção de perspectiva é, segundo Bonne, própria da noção de situs, desse local em que a imagem seria vista pelo espectador, este que gerencia os parâmetros de disposição dos objetos dentro do espaço específico da imagem. ${ }^{310} \mathrm{~A}$ "perspectiva inversa" não é a tomada de um situs de modo invertido, ou seja, que o espectador que gerencia o ponto de vista esteja no interior da imagem, o que seria impossível. Não é ela também uma tentativa de unificar o espaço de representação, apesar da aproximação que supõe seu próprio nome a uma perspectiva de tal tipo.

A imagem medieval não pensa a superfície de inscrição como um espaço de representação, mas de figuração, no sentido mais amplo da noção de figura e visual, discutidos por Didi-Huberman.

\footnotetext{
Dizemos o visual para precisar o que entendíamos mais acima pela fórmula arriscada do "inconsciente do visível". Falamos de visual e opômo-lo ao visível, para expressar a hipótese de que a tomada em consideração do mistério da encarnação visava ou tinha como efeito, perturbar a ordem do mundo visível e a ordem clássica da imitação. Ela devia perturbá-lo como um sintoma perturba um corpo, ou como um milagre (como diria Agostinho) perturba a ordem natural das coisas. ${ }^{311}$
}

Não é a página do manuscrito um espaço para a representação, mas para a figuração, para o desenvolvimento do visual, aquele que herda da Encarnação o direito de tornar presente o que é intangível, e não de representar o que é invisível. O visual é chamado, por Didi-Huberman, de o "inconsciente do visível", expressão que evidencia que a imagem medieval não representa o invisível, mas busca o intangível. O invisível é, por definição, uma realidade que não corresponde ao mundo sensível, é o oposto de visível. Contudo, dentro da teologia cristã, a encarnação altera a correspondência entre o ver e o visível. É possível ver Deus através de Cristo, através de todas as criaturas criadas à sua imagem e semelhança.

\footnotetext{
${ }^{309}$ PANOFSKY, Erwin. A perspectiva como forma simbolica. Lisboa: Ed.70, 1993.

310 BONNE, Jean-Claude. "Fond, surfaces, support. Panofsky et l'art roman". In: Panofsky. Paris: Centre Georges Pompidou/Pandora, 1983, p. 131.

${ }^{311}$ DIDI-HUBERMAN, Georges. Poderes da figura: exegese e visualidade na Arte Cristã. Revista Comunicação e Linguagens, n. 20. Tradução de Virgínia Andrade e Leonor Caroça. Lisboa, p. 159-173, 1994, p. 164.
} 
Pensemos também no poder do sonho no medievo, um meio em que se vê, se toca e torna sensível uma imagem que é intangível, mas que não é invisível. ${ }^{312}$

Estudar a imagem segundo os preceitos de construção pós-renascentistas e sob nosso entendimento atual de espaço significa negar a essas imagens seus meios próprios de "apreciação formal da superfície de figuração". ${ }^{313}$ Não conhecer o próprio corpo da imagem é permitir a afirmação de julgamentos de valor atrelados a uma forma e composição supostamente ainda imperfeitas. O caminho que trilhamos para estar diante da imagem medieval diz mais dos seus dispositivos, do modo como a imagem trabalha, que da tentativa de distanciarmo-nos do objeto e vê-lo sobre um prisma que ainda é guiado pelo mesmo olhar do situs.

Mais adequado será falarmos da espessura da imagem, um modo de figuração que cria planos sobre a superfície de inscrição, sem que se discuta a ideia de perspectiva ou da própria noção de profundidade na imagem. A composição da imagem medieval não se pauta por uma profundidade ou uma localização espacial mensurável. O funcionamento, através do ornamento como engrenagem, não se baseia em mensurações matemáticas, pois as imagens, bem como seus componentes pictóricos, conectam-se e se referenciam segundo um diálogo que ultrapassa o sentido narrativo e representacional.

Mesmo quando a imagem medieval fala sobre espaço, seu discurso apenas tangencia a ideia de medida. O Comentário a Ezequiel, por Ricardo de São Vitor (BNF lat. 14516), ${ }^{314}$ é uma referência a possíveis modos de figuração do templo e de suas medidas. São Vitor apresenta três tipos de figuração de edifícios: o primeiro corresponde ao que conhecemos como plano, ou planta baixa, a que São Vitor chama de in plano. Nessa estruturação, permitese avistar de cima, através do telhado, as disposições, proporções e medidas exatas do interior do edifício. No segundo tipo de estruturação, in alto, utiliza-se um corte da frente ou do perfil do edifício, com alguma elevação, que revela seu interior. E, por fim, outra figuração in

\footnotetext{
${ }^{312}$ SCHMITT, Jean-Claude. O sonho de Roberto de Mozat e a Majestade de Clermont. In: O corpo das imagens: ensaios sobre a cultura visual na Idade Média. Bauru, SP: EDUSC, 2007, p. 182-187; SCHMITT, Jean-Claude. A iconografia dos sonhos. In: ___ O corpo das imagens: ensaios sobre a cultura visual na Idade Média. Bauru, SP: EDUSC, 2007, p. 3030-305.

${ }^{313}$ BONNE, Jean-Claude. Fond, surfaces, support. Panofsky et l'art roman. In: Paris: Centre Georges Pompidou/Pandora, 1983, p. 117-134. et al. Erwin Panofsky.

${ }^{314}$ SCHMITT, Jean-Claude. De l'espace aux lieux: les images médiévales. Actes des congrès de la Société des historiens médiévistes de l'enseignement supérieur public. Construction de l'espace au Moyen Age:pratiques et représentations. 37e congrès, Mulhouse, 2006, p. 329.
} 
plano, em que se atém ao mesmo tempo ao comprimento, largura e altura do edifício, mas sem se preocupar, necessariamente, com as medidas e proporções.

No Beatus de Facundus, encontramos os dois últimos tipos de figuração de edifícios e espaços arquiteturais propostos por Ricardo de São Vitor. No f. 109, vemos uma figuração in alto, em que a Arca de Noé recebe um corte vertical e uma vista frontal (Figura 36). O corte permite a visão do interior da arca, as divisões dos pisos e os personagens que os ocupam. A Arca de Noé ocupa praticamente uma página inteira, divide espaço com apenas seis linhas de texto. Ela aparece no final do Livro II do Comentário ao Apocalipse, depois da explicação da entrega da carta por João à igreja de Laodicéia (Ap. 3, 14-22). Trata-se de um texto de Gregório de Elvira, bispo hispânico do século IV, tomado por Beato de Liébana para falar da identificação da Arca com a Igreja. A imagem aparece em um corte abrupto no texto de Gregório de Elvira, não adota a mesma organização que o restante do Comentário ao Apocalipse (storia-imagem-explanatio), visto que não há uma storia, mas um texto uno. Não se trata de uma imagem da explanatio, propriamente dita, mas de uma interpretação somada ao final do Livro II. ${ }^{315}$ No texto, aparecem trechos do Livro de Gênesis, sobre a Arca de Noé, a partir dos quais se criam relações com outros trechos bíblicos e uma interpretação deles, muito próximas ao que se desenvolve na explanatio dos trechos do Apocalipse. Por isso, alguns autores, como Yarza Luaces, ${ }^{316}$ afirmam ser uma imagem do comentário de Beato de Liébana, mas é preciso fazer a separação, já que a imagem não ocupa o mesmo lugar que nos comentários.

Mais importante que a descrição puramente espacial dos pisos da arca e dos animais que carrega, o texto privilegia as analogias com Cristo e a Igreja, bem como com o texto que antecede essa interpretação.

Farás uma arca de trezentos côvados de longitude, de cinquenta côvados de largura e trinta côvados de altura. Farás na arca uma cobertura e a um côvado a arrematará por cima. Ponha a porta da arca em seu lado e faça um primeiro piso, um segundo piso e um terceiro, etc. A produção da arca indicará claramente a figura de nossa Igreja. Não há dúvida alguma de que Noé representou a figura de Cristo. [...] Pois esta arca, que foi construída com madeiras incorruptíveis, indicava, como

\footnotetext{
315 Título da interpretação ao final do livro II: "INTERPRETATIO QUALITER ECCLESIA SIT CUM SEPTEM DICANTUR APERTISSIME PER ARCHA NOHE DE CLARATUR". CAMPO HERNÁNDEZ, Alberto del; FREEMAN, Leslie G.; GONZÁLEZ ECHEGARAY, Joaquín (ed.). Beato de Liébana. Obras completas y complementarias. Edição bilíngue do latim ao castelhano. Madrid: Biblioteca de Autores Cristianos, 2004, v. 1, p. 264-273.

${ }^{316}$ YARZA LUACES, Joaquín. Las miniaturas. In: WILLIAMS, John et al. Beato de Fernando I y Sancha. Barcelona: M. Moleiro, 2006, p. 152.
} 
disse, a fabricação da verdadeira Igreja, que vai permanecer sempre com Cristo. As sete almas que se concedem ao santo e justo Noé, é reconhecido que representam a figura das sete Igrejas, que por Cristo serão livradas da catástrofe do fogo do juízo, e vão reinar com Cristo em na nova terra. ${ }^{317}$

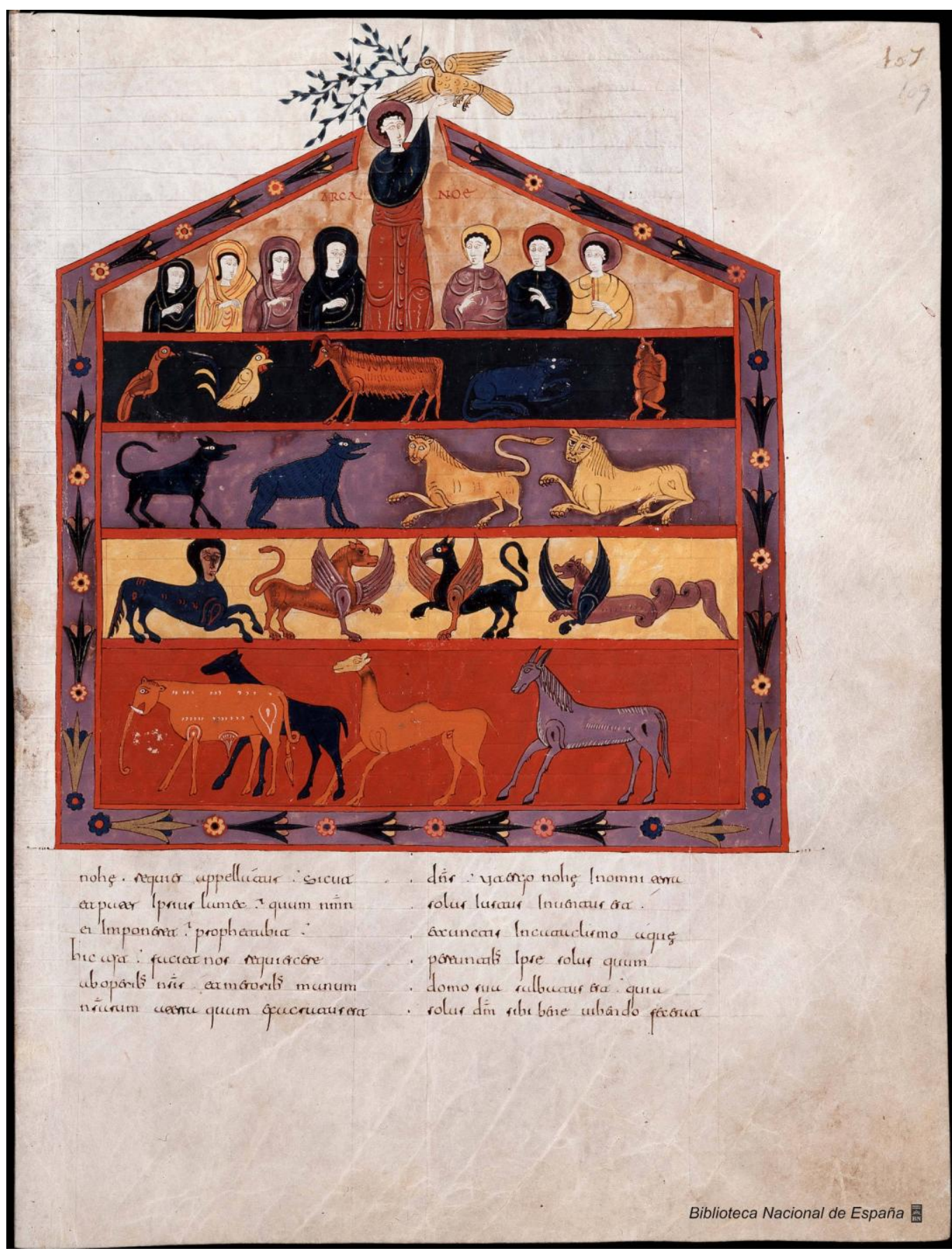

Figura 36. Beatus de Facundus, f. 109, Arca de Noé.

Fonte: www.bne.es

${ }^{317}$ CAMPO HERNÁNDEZ, Alberto del; FREEMAN, Leslie G.; GONZÁLEZ ECHEGARAY, Joaquín (ed.). Beato de Liébana. Obras completas y complementarias. Edição bilíngue do latim ao castelhano. Madrid: Biblioteca de Autores Cristianos, 2004, v. 1, p. 264-265. 
Sobre as divisões da arca, o texto explica cada um dos três pisos, ao traçar comparações com outros textos bíblicos, os quais remetem à ideia de morada, de casa e, simbolicamente, de mansões celestiais. O espaço físico da arca (e sua figuração na página) é um meio para as digressões espirituais. A escolha plástica em mostrar o interior da arca pode relacionar-se à dedicação do texto na divisão dos pisos, mas não tenta criar uma representação "fiel" do que é dito simbolicamente. A família de Noé ocupa o primeiro piso, filhos de um lado, a mulher de Noé as mulheres de seus filhos de outro. Não há um indício visual direto que reforce a identificação feita pelo texto desses personagens com as Sete Igrejas, aquelas para as quais João levou as cartas no texto anterior a esse. ${ }^{318}$ Em outras imagens, vemos esses indícios em elementos arquitetônicos, pela construção geometrizada da igreja (como nos ff. $78,82 \mathrm{v}, 87 \mathrm{v}, 92,100 \mathrm{v}, 106 \mathrm{v}$ ) ou pela identificação através de arcos e colunas (como nos ff. 46 e 262). Esse indício não está ao lado do tronco de cada personagem, mas sua ausência nos leva a pensar a arquitetura da própria arca, que é casa, que é morada celeste e que tem um corpo similar à representação do livro sagrado em outras imagens do Beatus de Facundus. Há um jogo de designações visuais pela forma pentagonal. Na imagem da primeira igreja, Éfeso (f.78), João porta um livro retangular, ornado em ouro. Na imagem seguinte (f. 82v), João porta um livro pentagonal, e na seguinte (f. $87 \mathrm{v}$ ), retangular, e assim segue a alternância, até o f. 106v, com um livro retangular. ${ }^{319}$ A próxima imagem é da Arca de Noé na forma de um grande pentágono com uma abertura superior, aquela indicada pelo texto do Gênesis. Na imagem seguinte, f. $112 \mathrm{v},{ }^{320}$ Cristo aparece em seu trono com o livro em forma de pentágono. A figuração do espaço da arca não guarda uma proximidade com um objeto que poderia sustentar-se sobre a água, mas toma o sentido simbólico como mais significativo. Também as bandas de fundo, usadas na arca, são de cores já utilizadas nas imagens anteriores das sete igrejas, bem como a ornamentação da borda é muito próxima à da primeira igreja e da imagem posterior, do f. $112 \mathrm{v} .{ }^{321}$ Jogos que criam diálogos entre as imagens do manuscrito e

\footnotetext{
${ }^{318}$ Beato de Liébana aborda, pelo texto, uma noção de espírito septenário, em que a família de Noé remete aos sete membros de um corpo, que também são os sete olhos do Senhor, as sete estrelas na mão direita do Senhor, as sete trombetas e as sete igrejas. CAMPO HERNÁNDEZ, Alberto del; FREEMAN, Leslie G.; GONZÁLEZ ECHEGARAY, Joaquín (ed.). Beato de Liébana. Obras completas y complementarias. Edição bilíngue do latim ao castelhano. Madrid: Biblioteca de Autores Cristianos, 2004, v. 1, p. 266-267.

${ }^{319}$ Esse movimento de alternância pode ser observado nos esquemas propostos no capítulo 4, figuras 27-33.

${ }^{320}$ Disponível em: <http://bdh-rd.bne.es/viewer.vm?pid=d-1806167>. Acesso em: 25 nov. 2015.

${ }^{321}$ Assim como a Arca de Noé relaciona-se pelo espírito septenário com as imagens anteriores, das sete igrejas, Beato de Liébana traça relações da Arca com a imagem apocalíptica seguinte. Por não ser a Arca de Noé uma imagem apocalíptica, mas de importante compreensão da Igreja como barca de salvação, não nos é estranho que Beato a queira integrar no conjunto das imagens apocalípticas, seja de modo pictural ou pelo texto. A relação da Arca com esta imagem, da visão de Deus entronizado e dos anciãos (Ap. 4, 1-6), pode ser pensada, sobretudo,
} 
que não podem ser pensadas nem de modo casual, nem mesmo como uma incapacidade para a representação de uma arca flutuante. A arca não sobrevive ao dilúvio por sua força material, cada elemento diz mais de uma morada e proteção celeste que de um objeto que flutua na água.

Insistimos nessas diferenciações para mostrar como a apreciação formal da superfície de figuração se dá de modo complexo, na relação com as indicações e analogias do texto, no diálogo com as outras imagens e com o texto que elas figuram. Como pesquisadores, temos sempre de estar atentos ao senso comum do "isso parece com...", "isso se deve a...", fórmulas que enrijecem os diálogos entre os planos da imagem. O que poderia ser erroneamente conjecturado sobre a presença de quatro seres fantásticos na Arca de Noé se não se atentasse para a importância do imaginário dentro do conceito de imago. ${ }^{322}$

Sobre o outro modo de figuração de edifícios, a de São Vitor, temos a utilização do in plano na imagem da Jerusalém Celeste (Ap. 21), aquela da história que finaliza o livro XII do Comentário ao Apocalipse (Figura 37). Na descrição do Apocalipse, a cidade santa é cercada por uma muralha grande e alta, feita de jaspe. As medidas da cidade são passadas a João pelo anjo que a mede com uma cana de ouro. Ela é quadrada, seu comprimento, largura e altura se equivalem. De cada lado do quadrado abrem-se três portas, cada uma delas feita de uma única pérola. Sobre as portas, doze anjos e nomes gravados que são as doze tribos de Israel. A cidade se assenta sobre doze pedras, ornamentadas com pedras preciosas, as quais levam os nomes dos doze apóstolos

pela explicação dada por Beato de Liébana. Na passagem, Deus aparece no céu, sentado em um trono, que, segundo a explanatio, é a Igreja. Deus tem aspecto semelhante a uma pedra de jaspe e cornalina. O jaspe. que é a cor da água e a cornalida, do fogo, são dois juízos estabelecidos para a consumação do mundo no tribunal de Deus: "[...] um já foi consumado no dilúvio por meio da água, o outro se consumará por meio do fogo. Estas comparações estão relacionadas com a Igreja, a que revestiu o Senhor. O íris rodeava o trono. O íris que rodeava o trono tem as mesmas cores. O íris é chamado também de arco; dele falou o Senhor a Noé e aos seus filhos, para que eles não tivessem na prole medo de Deus: ponho, disse, meu arco nas nuvens (Gen. 9, 13), para que já não temais a água, e sim ao fogo. Pois no arco aparece ao mesmo tempo a cor da água e do fogo; porque em parte é negro e em parte vermelho, para ser testemunho em ambos os juízos, quer dizer: um que vai se realizar pelo fogo, e outro que já foi realizado pela água". CAMPO HERNÁNDEZ, Alberto del; FREEMAN, Leslie G.; GONZÁLEZ ECHEGARAY, Joaquín (ed.). Beato de Liébana. Obras completas y complementarias. Edição bilíngue do latim ao castelhano. Madrid: Biblioteca de Autores Cristianos, 2004, v. 1, p. 278-279.

${ }^{322}$ YARZA LUACES, Joaquín. Los seres fantásticos en la miniatura castellano-leonesa de los siglos XI y XX. In:___ Formas artísticas de lo imaginario. Barcelona: Anthropos editorial del hombre, 1987, p.156-181. 


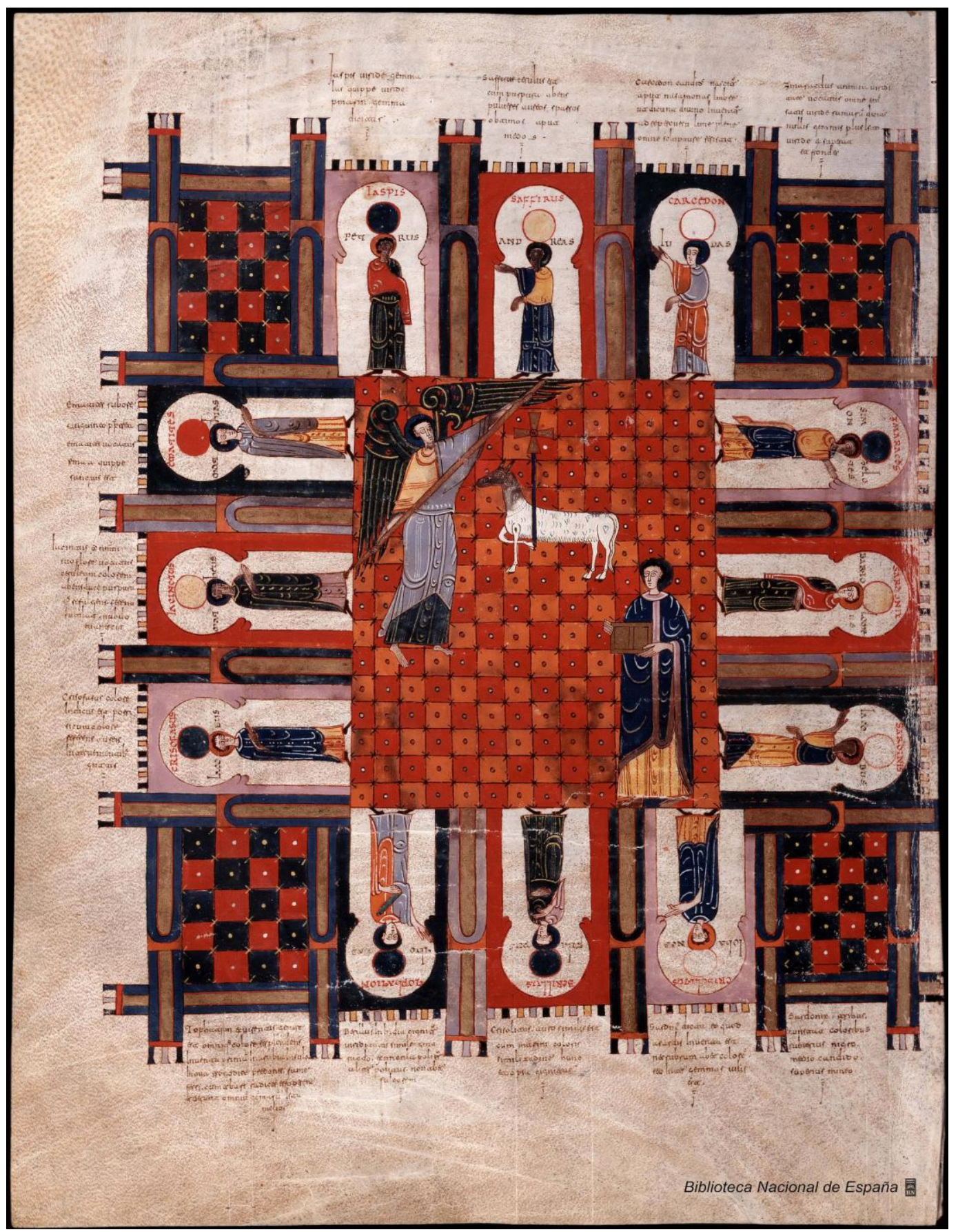

Figura 37. Beatus de Facundus, f. 253v, A Jerusalém celeste que desce do céu. Fonte: www.bne.es

$\mathrm{Na}$ imagem do f. $253 \mathrm{v}$, temos a altura dos muros rebatida sobre o plano do pátio. Desse modo vemos as outras dimensões de comprimento e largura. As doze portas possuem arco ferradura e são flanqueadas por um elemento arquitetônico que termina como torres com ameias, também há ameias por todo o perfil do muro. Toda essa estrutura é rebatida na planta do pátio. Na entrada de cada porta, onde deveriam estar os anjos e os nomes das tribos, 
encontramos personagens sobre cujas cabeças levam as doze pedras. Acima das pedras preciosas, escrito em rubrica, os nomes delas e, entre as pedras, os nomes dos apóstolos, mostrados de modo fragmentado. ${ }^{323}$ Acima das portas, se descreve cada uma das pedras e suas propriedades. Para Yarza Luaces, essas descrições parecem vir das Etimologias (XVI, 78), de Santo Isidoro. ${ }^{324}$

As pedras preciosas são ornamentos abundantes nesta visão de João.

Logo vi um céu novo e uma terra nova. Porque o primeiro céu e a primeira terra desapareceram, e o mar já não existe. E vi a cidade santa, a nova Jerusalém, que descia do céu, junto de Deus, composta como uma noiva se adorna para seu esposo [compositam sicut sponsam adornatam viro suo] ${ }^{325}$

A cidade tem o esplendor de pedra preciosa, como jaspe cristalino, e o pátio da cidade é de ouro puro (aurum mundum) e transparente como cristal. Nos comentários, Beato de Liébana relaciona a candura do cristal à graça do batismo. ${ }^{326}$ A cidade brilha sozinha, não precisa de iluminação, porque sua lâmpada é o Cordeiro. A Jerusalém Celeste, que desce do céu junto de Deus, é vista por João do alto de um monte, depois de ser levado para lá pelo anjo que mede a cidade (Ap. 21, 10). Mas, na imagem dos Beati, João se encontra dentro do pátio. Sua localização não é iconográfica, isto é, não corresponde fielmente ao texto com o qual dialoga. Ele está no plano central da imagem e segura o livro junto ao anjo com a vara de medir e ao cordeiro com a cruz. É a partir desse primeiro plano que os outros elementos se dispõem. É sobre esse plano central que os pés dos apóstolos repousam. Mas Pedro, André e Judas não estão acima ou sobre o anjo, o Cordeiro e João. Repousar os pés não quer dizer necessariamente encontrar o chão, mas entrar em contato direto com o mesmo plano pictórico

\footnotetext{
${ }^{323}$ As relações entre as pedras preciosas e os apóstolos se dão no seguinte arranjo: no lado superior, Pedro está com o jaspe, André com a safira e Judas com a calcedônia. À direita, está Simão Zelote com a esmeralda, Bartolomeu com a sardônica e Tiago com a cornalina. Abaixo, está João com o crisólito, Filipe com o berilo e Tomé com o topázio. Por fim, à esquerda, está Tiago com o crisoprásio, Mateus com o jacinto e Matias com a ametista.

${ }^{324}$ YARZA LUACES, Joaquín. Las miniaturas. In: WILLIAMS, John et al. Beato de Fernando I y Sancha. Barcelona: M. Moleiro, 2006, p. 272.

${ }^{325}$ CAMPO HERNÁNDEZ, Alberto del; FREEMAN, Leslie G.; GONZÁLEZ ECHEGARAY, Joaquín (ed.). Beato de Liébana. Obras completas y complementarias. Edição bilíngue do latim ao castelhano. Madrid: Biblioteca de Autores Cristianos, 2004, v. 1, p. 610-611, tradução nossa, grifo nosso.

${ }^{326}$ CAMPO HERNÁNDEZ, Alberto del; FREEMAN, Leslie G.; GONZÁLEZ ECHEGARAY, Joaquín (ed.). Beato de Liébana. Obras completas y complementarias. Edição bilíngue do latim ao castelhano. Madrid: Biblioteca de Autores Cristianos, 2004, v. 1, p. 619.
} 
sagrado, que é ocupado pelo Cordeiro, o anjo e João. ${ }^{327}$ Antes de ser uma superfície de apoio, o espaço central é o espaço sagrado de maior incidência da luz do Cordeiro. Não há uma divisão da imagem em planos de profundidade sequencial. Cada fragmento da imagem é um plano dessa grande camada que cobre a superfície de inscrição.

Podemos citar diversos planos dentro desta imagem - o plano de João, o plano do anjo, o plano do Cordeiro, o plano ornamentado que compõe o pátio e fundo dos três personagens, os quatro planos de distribuição das portas e muralhas, os quatro planos dos apóstolos, o plano das inscrições dentro das portas, o plano das inscrições acima das muralhas e quanto mais observarmos a imagem, mais planos serão distinguidos, de acordo com a relação criada entre as figurações envolvidas. A importância maior dada a essas relações faz com que medidas matemáticas, neste caso, sejam deixadas em segundo plano.

A própria medida da cidade não é seguida à risca, como seria hoje, quando alguém diz "quadrado", mas também não imaginamos um leitor do século XI que recorra a uma régua para saber se o iluminador seria milimetricamente fiel à indicação do texto. A imagem, então, a cidade, é ligeiramente maior na altura que na largura. As suas portas não abrigam os anjos que o texto "manda". Porque diz Beato de Liébana, na explanatio, que "[...] as doze portas e as doze tribos de Israel são os doze Apóstolos e os doze profetas: que é a Igreja constituída e consolidada no número doze. E estas doze portas conduzem a uma porta maior, que é Cristo. Portanto a porta é Cristo". ${ }^{328}$ Como as portas poderiam ser dispostas por uma perspectiva linear, ou ao menos de modo frontal, sem que todas se tornassem distantes do centro da imagem, que também é Cristo?

O anti-perspectivismo, denunciado por Panofsky na arte românica e que, por extensão, seria observado em outras produções medievais, torna-se um aspecto infundado, pois não faz parte da pauta de preocupações e discussões da imagem medieval no século XX. Parece uma questão simples, mas que atormentou por muito tempo os estudos sobre imagens medievais e, décadas depois, ainda nos esbarramos com alguns desses fantasmas.

\footnotetext{
${ }^{327}$ Para Panofsky, uma das grandes conquistas da produção românica foi a de dar chão aos corpos, de "[...] estabelecer uma 'nova unidade' entre os corpos e o espaço (p.111) - 'nova' e 'substancial' (p. 113), pois ela não era mais baseada na resolução cromática e algo flutuante dos corpos na luz, como na arte bizantina (p. 112), mas na solidarização estreita das figuras com seu suporte". BONNE, Jean-Claude. Fond, surfaces, support. Panofsky et l'art roman. In: et al. Erwin Panofsky. Paris: Centre Georges Pompidou/Pandora, 1983, p. 121.

${ }^{328}$ CAMPO HERNÁNDEZ, Alberto del; FREEMAN, Leslie G.; GONZÁLEZ ECHEGARAY, Joaquín (ed.). Beato de Liébana. Obras completas y complementarias. Edição bilíngue do latim ao castelhano. Madrid: Biblioteca de Autores Cristianos, 2004, v. 1, p. 619.
} 
Jean-Claude Bonne já denunciava, em 1983, os fantasmas criados por Panofsky em 1927. É preciso atentar-se sempre às datas e contextos em que as obras teóricas são escritas e suas repercussões, pois elas também têm seu próprio tempo e seu devido valor. Críticas são construídas para o reconhecimento de uma teoria e desdobramento de outras ideias. Repensar a visão de Panofsky sobre as composições espaciais da imagem românica é abrir margem para o questionamento do próprio espaço da imagem. Segundo Bonne, Panofsky conceberia o espaço

[...] como uma categoria universal suscetível de múltiplas determinações (psicofisiológicas, filosóficas. científicas, estéticas...), sem que se saiba bem o que ele é para ele: um tipo de forma a priori da sensibilidade ou "o espaço visual empírico", pois é, ao fim e ao cabo, este, e não um espaço em si (?), que constitui, nos dizeres de Panofsky (p. 126), o referente que a perspectiva "matematiza", ainda que ela faça também "abstração de sua estrutura própria" (ibid. e p. 110). Esse postulado autoriza igualmente uma série de reduções teóricas e históricas: se a arte tem por objeto formal a representação do espaço, ela tem por verdade a perspectiva, que encontra sua realização na "construção geométrica 'correta' descoberta na Renascença" e aperfeiçoada na sequência. ${ }^{329}$

Vista desse modo, a figuração do espaço não poderia culminar em outra coisa senão na perspectiva como um modelo a ser seguido. Mas o espaço no qual os planos da imagem se entrelaçam e se sobrepõem não é, de modo algum, neutro, ligado ao pensamento moderno de espaço "inteiramente racional, quer dizer, infinito, contínuo e homogêneo". ${ }^{330}$ É por sua nãoneutralidade, por não se tratar de um espaço homogêneo e limitado por relações de grandeza, que devemos evitar o termo espaço em prol dos "lugares" da imagem. O espaço do qual falamos acima, nas imagens da Arca de Noé e da Jerusalém Celeste, não é um espaço mensurável e ordenado segundo noções de profundidade. Ele é o lugar, ou lugares, onde a imagem figura seus potenciais simbólico, ritualístico e ornamental.

Jean-Claude Schmitt nos faz atentar para as distinções entre a nossa concepção de espaço e os lugares das imagens medievais através da diferenciação entre spatium e locus. ${ }^{331}$ A palavra spatium era pouco usada no medievo. Segundo Schmitt, ela aparece apenas 24

\footnotetext{
${ }^{329}$ BONNE, Jean-Claude. Fond, surfaces, support. Panofsky et l'art roman. In: Paris: Centre Georges Pompidou/Pandora, 1983, p. 119.

${ }^{330}$ BONNE, Jean-Claude. Fond, surfaces, support. Panofsky et l'art roman. In: et al. Erwin Panofsky. Paris: Centre Georges Pompidou/Pandora, 1983, p. 119.

${ }^{331}$ SCHMITT, Jean-Claude. De l'espace aux lieux: les images médiévales. Actes des congrès de la Société des historiens médiévistes de l'enseignement supérieur public. Construction de l'espace au Moyen Age:pratiques et représentations. 37e congrès, Mulhouse, 2006, p. 317-346.
} 
vezes na Vulgata. ${ }^{332}$ Suas significações giram em torno da ideia de distância ou intervalo, trata-se de um intervalo de tempo, para medir espaços específicos entre dois pontos ou como designação de locais precisos, um espaço que vem da ideia de espaçar. Apesar do nome, o spatium medieval também não diz respeito à nossa concepção matemática de superfície contínua do espaço.

A palavra locus era mais utilizada que spatium e possuía maior alcance semântico. ${ }^{333}$ Schmitt destaca alguns usos do termo e diz que o lugar (locus) não é uma noção abstrata, mas identificada pelo seu conteúdo concreto, como a tumba, a vila, o monastério, a igreja. Ele utiliza o texto de Teófilo, De diversis artibus, para localizar um uso específico de locus na preocupação de figuração:

\begin{abstract}
"No campo (in campo), sob o azul celeste e o verde, colocamos uma cor chamada veneda, que é uma mistura de giz preto e branco em que, quando seco, colocamos em seu lugar (ponatur in suo loco) uma fina camada de azul com gema de ovo misturada em uma grande quantidade de água [...]." ${ }^{334}$ Uma cor dada, uma figura ela mesma identificada à sua ou às suas cores encontrando seu "lugar próprio" na imagem ou mais precisamente em um de seus campos (campus, no sentido de zona ou de banda colorida). ${ }^{335}$
\end{abstract}

O espaço da imagem não é neutro nem converge para um mesmo fim. Ele pode ser uma localização, mas não um elemento homogêneo que se possa tomar como unificado. $\mathrm{O}$ espaço não é uno. Se a imagem medieval "pensa em cores", como diz Jean-Claude Bonne, ${ }^{336}$

\footnotetext{
${ }^{332}$ SCHMITT, Jean-Claude. De l'espace aux lieux: les images médiévales. Actes des congrès de la Société des historiens médiévistes de l'enseignement supérieur public. Construction de l'espace au Moyen Age:pratiques et représentations. 37e congrès, Mulhouse, 2006, p.320.

${ }^{333}$ No Novum Glossarium, encontramos oito grupos de ocorrências que se subdividem em outros muitos usos do termo - (1) lugar, endereço, região: lugares santos (lugar sagrado da presença da relíquia, lugar de peregrinação, Terra Santa - Jerusalém, por exemplo-, igreja, monastério, terras de uma igreja ou monastério, tumbas) partes do corpo, vila, asilo, assento (de circo), prebenda (função de um cônego), propriedade rural, tenda; (2) figurar lugar, ocasião, pretexto; (3) ordem, classificação; (4) situação, estado; (5) ponto, questão, matéria; (6) passagem de uma escrita, de um discurso; (7) sentido temporal; (8) Termo técnico filosófico (espacialidade e tópicos de argumentos). ARNALDI, Francesco et al. Ornamentum In: Copenhague: Munksgaard, fascículo Ordior-Oz, 1983-2011. Disponível em: <http://scriptores.pl/ngml/view?docId=Ordior-Oz/Ordior-Oz.xml>. Acesso em: 22 dez. 2015.

${ }^{334}$ DODWELL, C. R. (ed. trad.). Theophilus: The Various Arts. Londres-New York, 1961, p. 13.

${ }^{335}$ SCHMITT, Jean-Claude. De l'espace aux lieux: les images médiévales. Actes des congrès de la Société des historiens médiévistes de l'enseignement supérieur public. Construction de l'espace au Moyen Age:pratiques et représentations. 37e congrès, Mulhouse, 2006, p. 323.

${ }^{336}$ BONNE, Jean-Claude. Penser en couleur: à propôs d'une apocalyptique du X siècle. In: SCHMITT, JeanClaude; HÜLSEN-ESCH, Andrea von (Org). Die Methodik der bildinterpretation / Les méthodes de l'interpretation de l'image. Deutsch-französische Kolloquium 1998-2000. Göttingen: Max-Planck Institut für Geschichte, 2002, v.2, p. 355-379.
} 
ela também pensa em locus. Segundo Schmitt, a imagem medieval "[...] consiste em uma montagem ordenada e sutilmente hierarquizada de 'lugares'". ${ }^{337}$ Acrescentamos ao pensamento de Schmitt a compreensão de que essa hierarquização pode ser regida pelo trabalho do ornamento. Através de marcas plásticas e cromáticas, o ornamento gere a imagem de forma estrutural. Entendamos estrutura não como um bloco rígido e mensurável, mas uma rede de associações dialógicas entre o corpus e o lugar que o compõe. Relembremos o campo central da imagem do f. 253v, da Jerusalém Celeste. O lugar do anjo, o lugar do Cordeiro e o lugar de João, são lugares carregados de ornamentação que estrutura a narrativa e as formas simbólicas, de modo a criar tensões com os outros personagens. As tensões se estendem em rede para fora da imagem, como nas relações indiciais entre a estrutura da Arca de Noé e a estrutura pentagonal do livro sagrado.

São essas relações indiciais, engendradas pelo ornamento, que permitem as imagens se referenciarem umas as outras e distinguirem a criação de seus lugares. Ao observarmos os fólios com imagens no sistema de blocos (Anexo A), notamos a formação de um grupo de imagens de fólio duplo: ff. 147v-148 (Adoração do Cordeiro e os 144 mil - Ap. 7, 9-12), ff. 186v-187 (Mulher vestida de sol e a serpente, Ap. 12) e ff. 250v-251 (Juízo Final, Ap. 20, 11 15). Neste bloco, o ornamento atua em diversas instâncias, desde a beleza honorífica até a estruturação dos lugares celeste, terrestre e da morte e punição no inferno. Podemos observar a cor-ornamento ser aplicada na imagem em prol de sua varietas, principalmente na imagem de ff. $147 \mathrm{v}-148$, em que toda a nação que se põe diante do Cordeiro e do trono está, segundo o texto, vestida com vestes brancas (stolis albis) e com palmas nas mãos. ${ }^{338}$ Também o trono da imagem do Juízo Final (ff. 250v-251) teria indicações textuais para ser branco e resplandecente (thronum magnum, album et candidum), ${ }^{339}$ mas figura em ouro.

\footnotetext{
${ }^{337}$ SCHMITT, Jean-Claude. De l'espace aux lieux: les images médiévales. Actes des congrès de la Société des historiens médiévistes de l'enseignement supérieur public. Construction de l'espace au Moyen Age:pratiques et représentations. 37e congrès, Mulhouse, 2006, p. 324.

${ }^{338}$ CAMPO HERNÁNDEZ, Alberto del; FREEMAN, Leslie G.; GONZÁLEZ ECHEGARAY, Joaquín (ed.). Beato de Liébana. Obras completas y complementarias. Edição bilíngue do latim ao castelhano. Madrid: Biblioteca de Autores Cristianos, 2004, v. 1, p. 364-365

${ }^{339}$ CAMPO HERNÁNDEZ, Alberto del; FREEMAN, Leslie G.; GONZÁLEZ ECHEGARAY, Joaquín (ed.). Beato de Liébana. Obras completas y complementarias. Edição bilíngue do latim ao castelhano. Madrid: Biblioteca de Autores Cristianos, 2004, v. 1, p. 608-609
} 


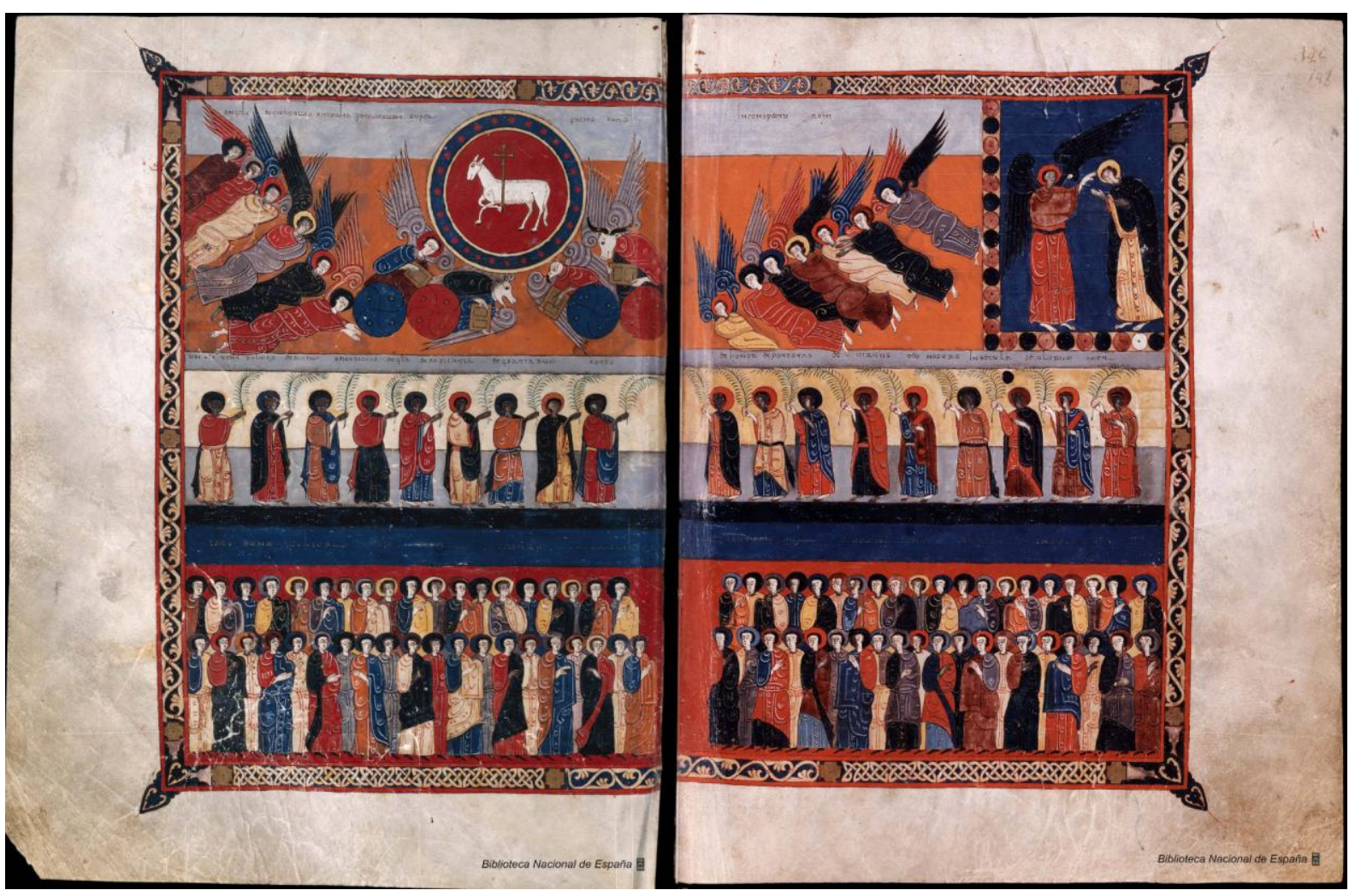

Figura 38. Beatus de Facundus, ff. 147v-148 (Ap.7, 9-12).

Fonte: www.bne.es

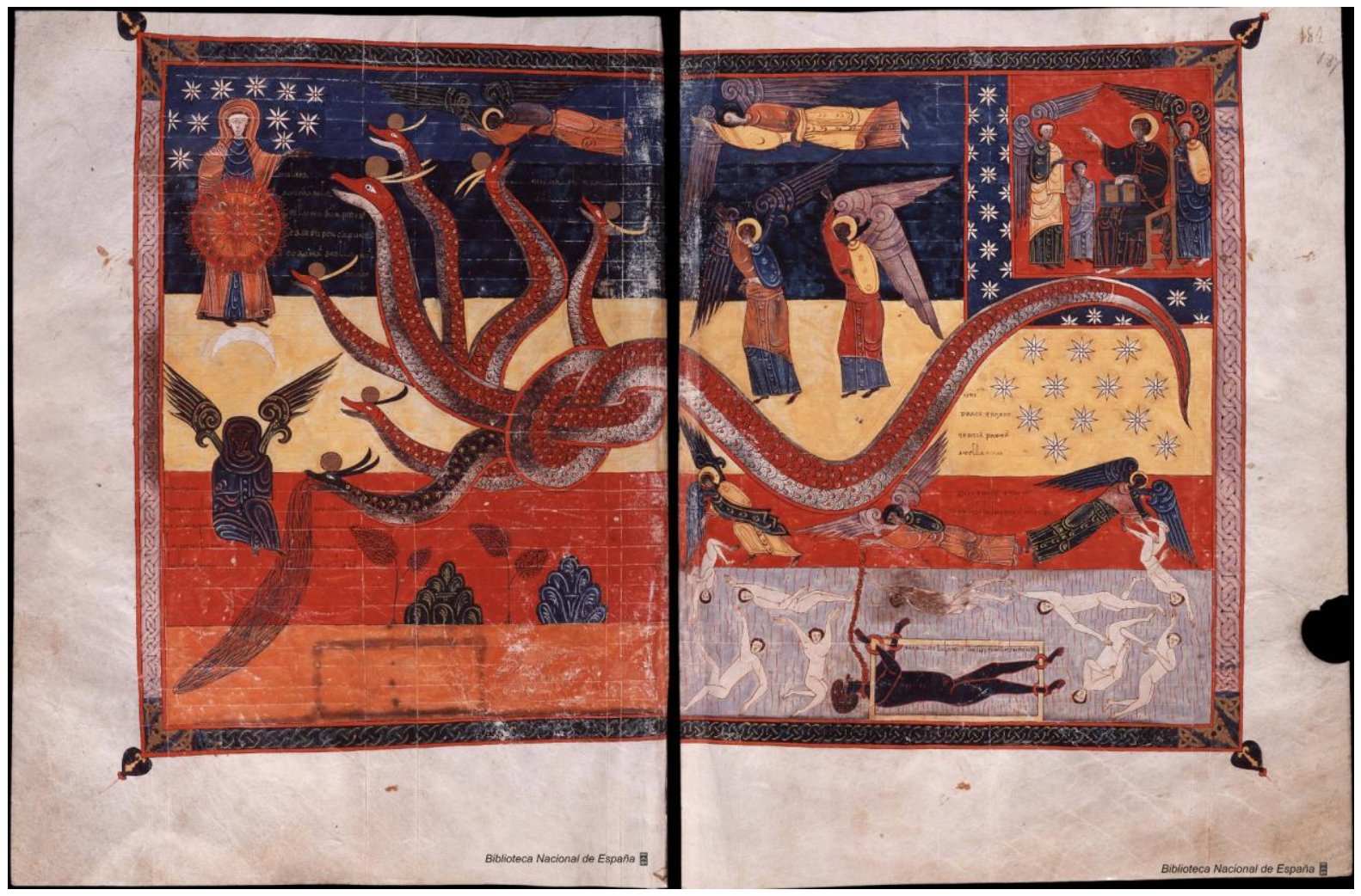

Figura 39. Beatus de Facundus, ff. 186v-187 (Ap 12).

Fonte: www.bne.es 


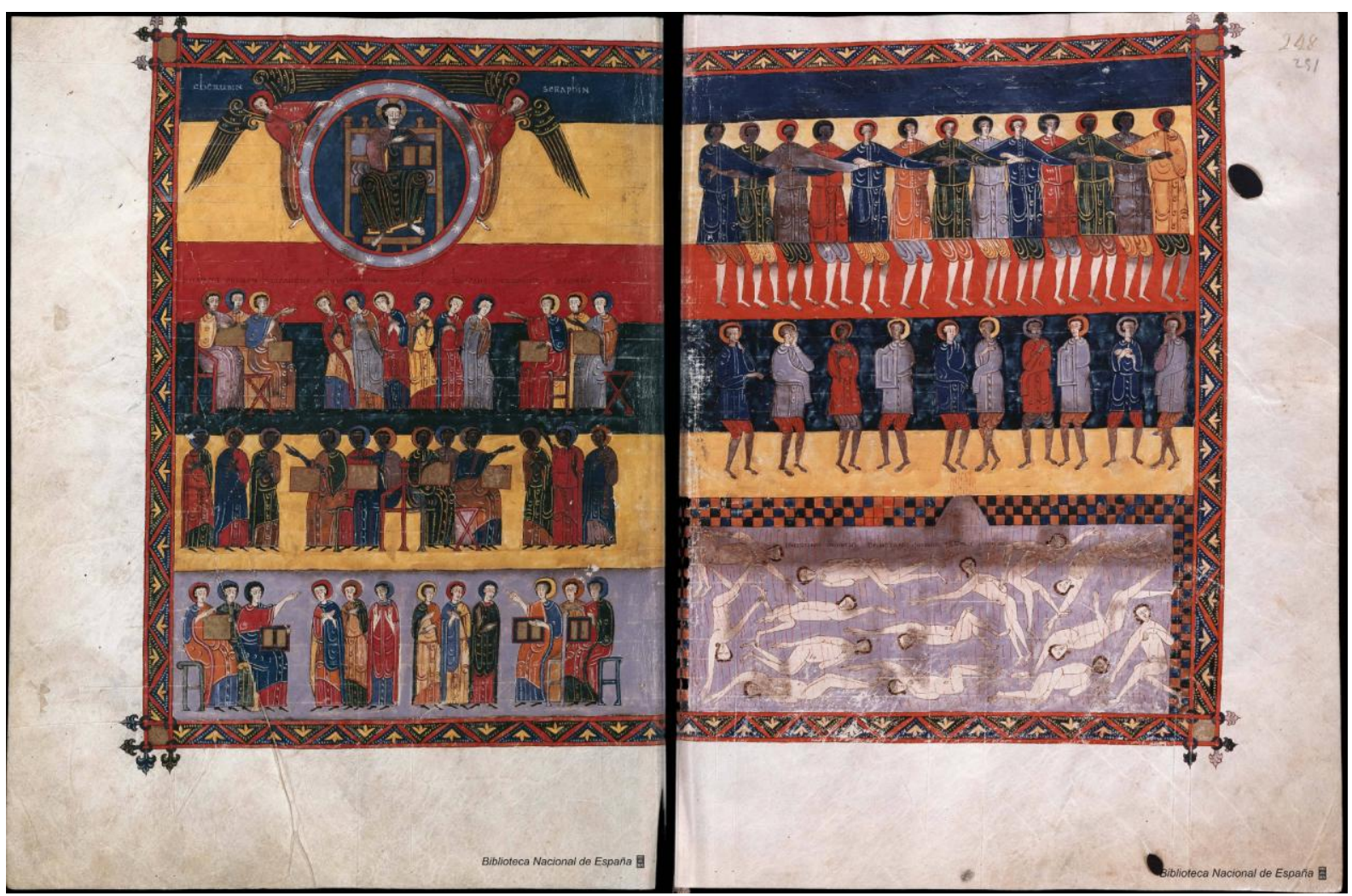

Figura 40. Beatus de Facundus, ff. 250v-251 (Ap 20, 11-15).

Fonte: www.bne.es

Em todas as três imagens, as bandas de cor do campo aumentam a profusão cromática e auxiliam estruturalmente a narrativa ao dividir as cenas distintas em estratos. Nesse papel estrutural, o ornamento parece aproximar mais a imagem dos ff. $147 \mathrm{v}-148$ a dos ff. $250 \mathrm{v}-251$, visto que, na figuração da mulher vestida de sol (ff. 186v-187), a serpente torna-se o principal elemento ornamental ordenador e centralizador da imagem e as bandas de cor a auxiliam. As cabeças da serpente dividem a narrativa em três tempos da história: três cabeças atendem a imagem da mulher, duas cabeças dedicam-se a cena de inundação da mulher no deserto e as outras duas cabeças restantes enfrentam Miguel e os anjos. Também o corpo da serpente que, com sua calda, arrasta um terço das estrelas do céu, localiza o lugar celeste na ponta de sua calda.

Ao nos atentarmos para o poder de orquestração do ornamento, a construção composicional da imagem surge em consonância com a série, e dizemos série não apenas dentro deste bloco específico, mas no manuscrito como um todo. Selecionada a série, compomos um esquema que nos permite pensar as relações compositivas entre as imagens do Beatus de Facundus evidenciadas nessa série, mas não cristalizadas sobre ela. 


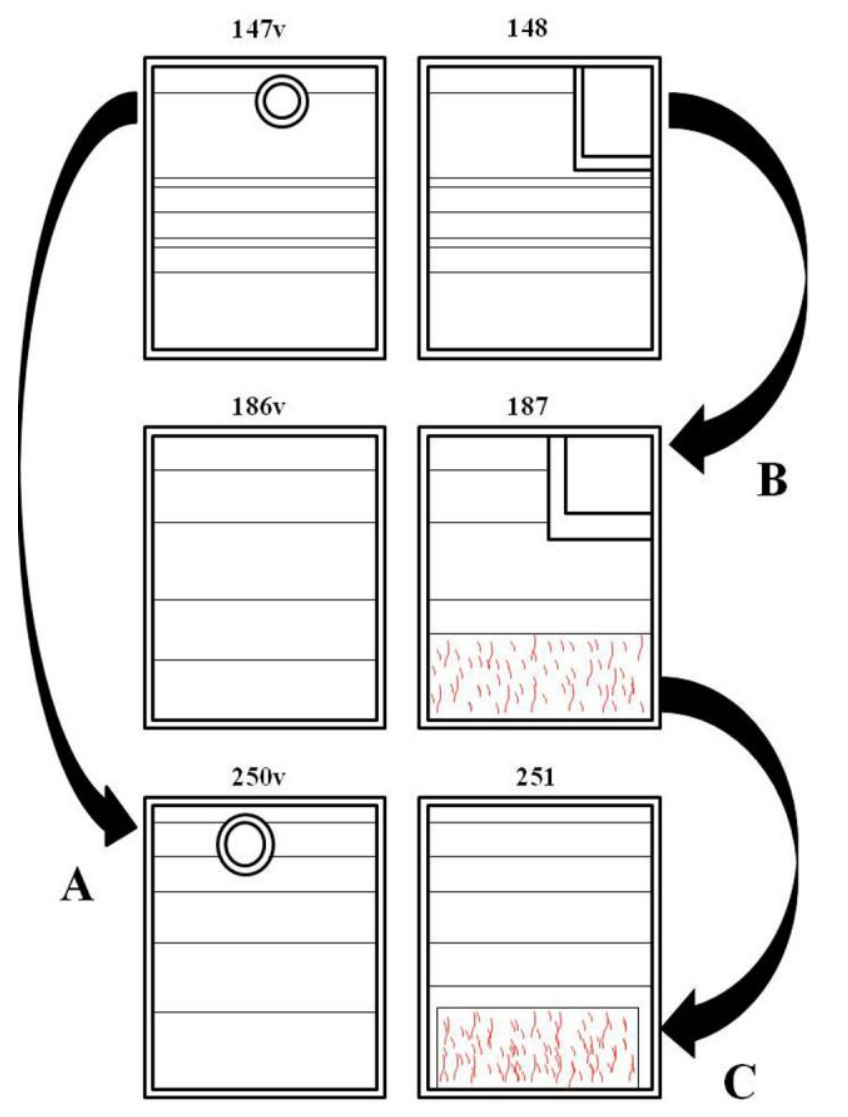

Figura 41. Esquema de ressonâncias e prefigurações Fonte: Elaborado pela autora.

O esquema observa a ressonância compositiva de imagens, como o ornamento marca essas imagens e as orquestra segundo a definição de lugares. As setas representadas no esquema são lógicas de composição que usam a repetição gráfica para marcar lugares semelhantes. Na seta "A", observamos que o lugar do Cordeiro, no f. 147v, é também aquele em que figura o Cristo no Juízo Final (f. 250v). Esse lugar celeste, que ocupa os estratos mais altos da página, apresenta-se como um campo monocromático de forma circular, completa ou interrompida pela borda da imagem e circundado por uma borda ornamentada. ${ }^{340}$ Quando o Cristo (ou Deus na figura de Cristo) é figurado nesse lugar, Ele sempre está sentado ao trono com o livro nas mãos; no caso do Cordeiro, ele está com a cruz ou com a cruz e o livro. O campo de cor dessa espécie de mandorla pode ser vermelho ou azul. No caso do Cordeiro, ele

\footnotetext{
${ }^{340}$ Existe algumas alterações na forma circular do lugar celeste, pois pode ser um círculo interrompido, que dá origem a um semicírculo (f. 173) ou uma forma que tende ao circular (f. 116v, que aparenta ser um arco), ou pode distanciar-se mais do circular para um oval "deformado" (f. 254, em que a mandorla do Cristo eco com a forma do rio visto por João).
} 
aparece, dentro da forma circular, apenas no f. $147 \mathrm{v}$ e no f. $116 \mathrm{v}$, ambas de campo de cor vermelha. ${ }^{341}$ Já no lugar celeste, habitado pelo Cristo, há uma variação de brilho e saturação no campo de cor de matiz vermelha ou azul, que diversifica o campo também para uma cor vermelho alaranjada (ff. 141v e 177) ou para uma cor azul que tende ao preto (f. 162v) ou ao branco (f. 254) na escala de valores. ${ }^{342}$ A cor da borda varia entre vermelho, azul (e azul claro) $^{343}$ e púrpura (apenas no f. 112v). A ornamentação das bordas inclui um determinado número de estrelas (ou flores), em geral com oito pontas (ou pétalas), à exceção do f. 116v, que é ornada por pequenos círculos amarelos. As estrelas podem ter uma relação com Ap. 22, 16 "Eu, Jesus, enviei meu anjo para dar testemunho a respeito das Igrejas. Eu sou a prole e o descendente de Davi, a brilhante estrela da manhã". ${ }^{344}$ Segundo Sepúlveda González, o uso das estrelas para referir-se a Cristo é frequente na iconografia prerromânica, ainda que o número de pontas varie. ${ }^{345} \mathrm{O}$ número oito, segundo ele, pode estar relacionado à identificação de Cristo com Vênus, a estrela da manhã, que, no mundo antigo, se representava como uma estrela de oito pontas. A imagem do f. $230 \mathrm{v}{ }^{346}$ nos apresenta uma outra relação, a de uma estrela de oito pontas que é, também, uma cruz, da qual sai uma linha na junção de cada braço, como na formação da rosa dos ventos. Essa estrela, que pertence ao céu do Cordeiro, é branca apenas em quatro pontas, a formar uma cruz, e nas pontas restantes permanece apenas o desenho em linha preta. Essa cruz é uma estrela e faz eco formal com a cruz portada pelo Cordeiro. Além disso, a estrela aparece claramente como referência a Cristo no f. 145, em que

\footnotetext{
${ }^{341}$ No f. $147 \mathrm{v}$, o Cordeiro porta a cruz e a borda, de cor azul, é ornamentada com pequenos círculos vermelhos com pontos amarelos ao centro e riscas paralelas de linha amarela entre cada círculo. A borda azul ainda é circundada, na porção interna e externa, por uma estreita linha amarela. No f. 116v, o Cordeiro porta além da cruz, um livro em forma pentagonal. A borda é de cor vermelha, ornamentada com pequenos círculos amarelos com pontos pretos ao centro (dois círculos, que estão localizados acima da cruz, na borda, têm ao redor do ponto preto, uma estreita linha vermelha,). A linha, que circunda a borda na porção interna, é de cor azul, que tende ao preto e, na parte externa, de cor púrpura. As cores e a composição deste espaço celeste do f. 116v dialogam diretamente com o espaço que Deus ocupa na mesma imagem. A ornamentação das bordas e a composição, de um modo geral, fazem uma imagem remeter-se à outra pela figuração do lugar do Cordeiro.

${ }^{342}$ Além desses fólios, o Cristo aparece nessa espécie de mandorla circular nos ff. 112v (campo de cor vermelha), 116v (azul), 173 (vermelha), 182v (vermelha), 250v (azul), 262 (azul) e no f. 187, o campo é de cor vermelha, mas a forma é quadrada. Estes recorte estão disponíveis em: <http://notamanuscrita.com/2016/01/09/beatusdefacundus/>.

${ }^{343}$ A borda azul clara é usada quando o campo de cor do lugar celeste é azul: ff. 205, 250v e 262.

${ }^{344}$ CAMPO HERNÁNDEZ, Alberto del; FREEMAN, Leslie G.; GONZÁLEZ ECHEGARAY, Joaquín (ed.). Beato de Liébana. Obras completas y complementarias. Edição bilíngue do latim ao castelhano. Madrid: Biblioteca de Autores Cristianos, 2004, v. 1, p. 634-635

${ }^{345}$ SEPÚLVEDA GONZÁLEZ, María de los Ángeles. Los anagramas y el programa iconográfico de Quintanilla de las Viñas: una hipótesis de interpretación. La España Medieval. Madri, Editorial de la Universidad Complutense, Tomo V, v. 9, p. 1217-1248, 1986, p. 1230.

${ }^{346}$ Disponível em: <http://bdh-rd.bne.es/viewer.vm?pid=d-1806167>. Acesso em: 25 nov. 2015.
} 
o anjo sobe do oriente, desde onde sai o sol, este figurado como um grande círculo vermelho, ornado por uma estrela de oito pontas, um conjunto que é estrela, sol e Cristo.

De todo modo, as variações na figuração do lugar celeste são consideradas pequenas diante das possibilidades formais de figuração de um lugar. $\mathrm{O}$ eco criado pela adoção de uma determinada configuração permite que identifiquemos o lugar celeste mesmo na ausência do personagem divino que o habita. É o que ocorre na imagem de fólio duplo, ff. 176v-177, referente ao Ap. 10, 11, 1-2. No f. 176v. Nessa imagem, o anjo, que é visto por João, tem o pé direito sobre o mar, o pé esquerdo sobre a terra e eleva a mão direita ao céu para fazer o juramento sobre a consumação do reino de Deus, quando o sétimo anjo tocar a trombeta. ${ }^{347} \mathrm{O}$ texto do Apocalipse indica que o local para onde aponta o anjo é um lugar celeste e a imagem o confirma pela marca ornamental de um círculo vermelho, de borda azul, interrompido bela borda da imagem. A borda do círculo interrompido é ornada com sete estrelas brancas de oito pontas e linhas vermelhas nos limites interno e externo da borda. Não há um corpo celeste que habite este lugar, no f. 176v, mas as marcas plásticas e cromáticas o aproximam das outras figurações celestes, assim como aproximam o lugar celeste do f. 177. Este lugar é uma pequena fração do "mesmo" círculo interrompido no fólio anterior, mas com duas diferenças: o campo de cor do círculo e a linha do limite externo da borda são de cor vermelha alaranjada, enquanto apenas a linha do limite interno da borda é de cor vermelha, de semelhante intensidade àquela usada no campo de cor e nas linhas da imagem anterior; a segunda diferença está na presença de uma mão em gesto de benção, que sai do lugar celeste para abençoar João. Esta é a mão do Cristo, identificado pela figuração da nuvem azul com linhas brancas, como já havia sido figurado no f. 43v. Essa pequena nuvem faz eco formal à nuvem do fólio anterior, habitada pelo anjo, que é, segundo a explanatio, Cristo. Esses ecos, ou ressonâncias, ou dobras (Bonne) com pequenas alterações, são modos de orquestração ornamental da imagem, que permitem a presença do lugar celeste apenas de modo indicial, sem a necessidade da presença pictórica do Cristo ou do Cordeiro. Essa permissão é franqueada pelo ornamento mesmo diante de alterações na principal composição adotada, como na identificação do lugar celeste no f. 187, em que a característica mandorla circular é substituída por uma retangular, interrompida pela borda da imagem, a qual assume a mesmas marcas ornamentais usadas nas outras figurações do lugar celeste (campo de cor vermelha, borda azul ornamentada por estrelas de oito pontas e com linhas limites na cor vermelha).

\footnotetext{
${ }^{347}$ A storia e a explanatio dessa passagem encontra-se em CAMPO HERNÁNDEZ, Alberto del; FREEMAN, Leslie G.; GONZÁLEZ ECHEGARAY, Joaquín (ed.). Beato de Liébana. Obras completas y complementarias. Edição bilíngue do latim ao castelhano. Madrid: Biblioteca de Autores Cristianos, 2004, v. 1, p. 434-441.
} 
Dentro dessa mandorla retangular figuram o Senhor, o menino, que é filho da mulher vestida de sol, e dois anjos que flanqueiam o trono. A legitimação do espaço como celeste já se dá pela presença de Deus, mas neste conjunto a forma retangular aproxima esta imagem daquela da adoração do Cordeiro (ff. 147v-148), em ressonância ao lugar habitado pelo anjo e João, o anjo que é Deus, o Ancião. Apenas nestes dois fólios, ff. 148 e 187, o lugar celeste é retangular. Essa ressonância é representada, no esquema, pela letra "B".

Por fim, observamos a figuração do inferno, com mortos que nadam em um lago de fogo, no dia do Juízo Final (f. 251). As chamas que ardem nesse lago saem por uma pequena abertura na borda superior, a atingir aqueles que se colocam em posição de dor, com o corpo levemente contorcido e as mãos em partes do corpo, como no queixo ou nos olhos. A figuração do inferno como um campo retangular bordado por ornamentos geométricos aparece em outras imagens, nos ff. $187,243 \mathrm{v}$ e 249 , mas sem a borda ornamentada, apenas como um campo de mesma cor (azul claro que tende ao violeta), com corpos nus que nadam, semelhante ao f. 251 do Juízo Final, mas também com Satanás ou a Besta. A figuração do f. 187 apresenta uma fusão ${ }^{348}$ dos elementos que compõem as imagens dos ff. $243 \mathrm{v}$ e 245 , como uma prefiguração do lago de fogo do Juízo Final (seta "C"). Não há uma justificativa textual, por parte do Beato de Liébana, para a presença do inferno no f. 187, nem na storia (Ap. 12), nem na explanatio. O inferno aparece no plano pictórico como uma prefiguração do que acontecerá posteriormente com a serpente, aquela que aparece nessa imagem como o elemento norteador da narrativa, sobre o qual a história se desenvolve. O inferno parece uma balança que equilibra a escala ornamental, tensionada entre a monumentalidade da serpente e o lugar celeste, franqueado pela forma retangular. ${ }^{349}$

Esses modos de estruturação geridos pelas marcas ornamentais, nas propriedades cromáticas ou nas formas geométricas, apresentam lugares que se parafraseiam. A

\footnotetext{
${ }^{348}$ Jean-Claude Bonne chama de fusão a uma forma de junção, de solidarização de elementos, que leva à noção de continuidade ao conjunto. "Diremos convencionalmente que há fusão quando os protagonistas de uma mesma ação ou os elementos de um motivo se tornam solidários com o seu lugar ou se soldam uns aos outros em composição fechadas. Esse modo de junção se articula claramente com a descontinuidade românica, pois, sob o efeito da compartimentagem que o limita, um segmento tenderá a se homogeneizar ou a fazer bloco consigo mesmo. Entretanto, a fusão também pode constituir uma forma de franqueamento por contato ou encavalamento". BONNE, Jean-Claude. L'art roman de face et de profil: le tympan de Conques. Paris: Le Sycomore, 1984, p.191, tradução de Eduardo Henrik Aubert.

${ }^{349} \mathrm{O}$ franqueamento (franchissement) é, para Bonne, uma ultrapassagem autorizada ou transgressiva de limites, ou mesmo uma ultrapassagem não efetuada, apenas sugerida. $O$ franqueamento designa uma ruptura para realçar ligações e as mobilidades dentro da imagem. "O franqueamento responde à necessidade de estabelecer ligações e de garantir uma certa mobilidade em um cosmo estático, hierárquico e descontínuo". BONNE, Jean-Claude. L'art roman de face et de profil: le tympan de Conques. Paris: Le Sycomore, 1984, p.190, tradução de Eduardo Henrik Aubert.
} 
materialidade da imagem, pelas marcas de repetibilidade ornamental, dialoga com o funcionamento recapitulador do texto apocalíptico. As imagens, assim como o texto, mesclam passado, presente e futuro, falam de coisas que vão acontecer, quando, na verdade, já pertencem ao passado, pois o dia do Juízo Final é inevitável e já foi visto e figurado. Trata-se daquilo que Didi-Huberman chama de poder de iminência da imagem, a praefiguratio. Essa operação "[...] exige que toda a figura tenha nela o seu próprio destino". ${ }^{350}$ A figura da serpente no céu e aquela jogada a Terra, já tem, em seu corpo, a prefiguração de seu destino prisioneiro no inferno, ${ }^{351}$ assim como um círculo vermelho com borda azul ornada de estrelas brancas prefigura a presença do Cristo. ${ }^{352}$

A noção de prefiguração, da iminência de uma designação por figura, é útil para pensarmos em uma convergência ornamental que explora também a parcela do imaginário (imaginatio) da imago, da profundidade que alcançam essas figuras dentro da cultura cristã. Deus aparece nas imagens do Beatus de Facundus como um anjo, como um ancião, como Cristo, mas Ele não se nomeia como Deus senão por suas figuras. Estendemos a noção de empréstimo para o ornamento que figura Cristo que figura Deus. Na repetibilidade de traços ornamentais, a imagem é orquestrada por um tipo de série que faz os lugares circularem como em um espelho que duplica, mas que também transforma. A imagem em série lida com o indício para a organização de sua narrativa segundo uma engrenagem ornamental. Essa engrenagem divide a imagem em estratos pelas bandas de cor no campo, ela faz uso das

${ }^{350}$ DIDI-HUBERMAN, Georges. Poderes da figura. Exegese e visualidade na Arte Cristã. Revista de Comunicação e Linguagens, n. 20, p. 159-177, 1994, p. 169-170.

${ }^{351}$ Essa prefiguração é observada principalmente na fusão dos elementos no f. $243 \mathrm{v}$, em que o anjo vem do céu com a chave do abismo e uma corrente, acorrenta e aprisiona a serpente, que é o Diabo, por mil anos (Ap. 20, 1 3). Essa corrente é a mesma mostrada no f. 187 e o diabo aparece como serpente e como uma besta de quatro patas, que se assemelha ao Hades, do f. 135, que acompanha o quarto cavaleiro do Apocalipse, e as outras bestas presentes no manuscrito.

352 Talvez pudéssemos aqui também pensar as relações de repetibilidade através do conceito de intericonicidade, concebida por Jean-Jacques Courtine, contudo, precisaríamos fazer algumas ressalvas, pois o trabalho de Courtine dedica-se à cultura visual atrelada à análise semiológica das imagens em conjunto com o campo de análise do discurso, que ultrapassa o nosso escopo atual de trabalho. Mas vale citar como possível referência ao estudo de ressonâncias figurativas, pois "[...] toda imagem se inscreve no interior de uma cultura visual e essa cultura visual supõe a existência de uma memória visual no indivíduo, de uma memória das imagens na qual toda imagem tem um eco. Há um 'sempre-já' de uma imagem. Essa memória das imagens pode ser uma memória das imagens externas percebidas, mas pode muito bem ser a memória das imagens internas sugeridas pela percepção exterior de uma imagem. Então, a noção de intericonicidade é uma noção complexa, porque ela supõe o estabelecimento da relação de imagens externas, mas também de imagens internas, as imagens das lembranças, as imagens que guardamos na memória, as imagens das impressões visuais armazenadas pelo indivíduo. Não há imagem que não nos faça ressurgir outras imagens, tenham essas imagens sido vistas antes, ou simplesmente imaginadas". Courtine citado em MILANEZ, N. O corpo é um arquipélago. In: NAVARRO, P. (Org.). Texto e discurso. São Carlos: Claraluz, 2006, p. 168. Ver também COURTINE, Jean-Jacques; MARANDIN, Jean-.Marie. Quel objet pour l'analyse du discours? in Matérialités discursives. Lille: Presses Universitaires de Lille, 1981, p. 21-35. 
propriedades cromáticas para destacar elementos, como uma rubrica pictórica, ${ }^{353}$ e usa a convergência composicional para definir lugares distintos na imagem. Toda essa engrenagem estrutural, gerida pelo ornamento, não se restringe ao "lugar da imagem", mas também toma posse do corpo da letra, do texto, pois texto e imagem não são campos em eterno solilóquio. Em um manuscrito iluminado, como o Beatus de Facundus, o texto e a imagem fazem parte da mesma série, estão em tensão dentro do objeto. Através da tensão, travam-se importantes diálogos, nos quais se ultrapassa as relações iconográficas e ilustrativas, como observamos, pela construção da imagem segundo lógicas próprias. Perguntamos, então, se não haveria, nesse diálogo, ferramentas comuns na construção do espaço pictórico e do espaço escritural. Na medida em que ambos trabalham sobre a mesma superfície de inscrição e compartilham do mesmo suporte, é de se supor que as tensões entre texto e imagem sejam mais íntimas que a ampla noção de discurso e linguagem. Com frequência, no Beatus de Facundus, a imagem fará uso dos recursos escriturais para compor sua estrutura. À exceção das imagens entre os ff. 6-17, ocupados pelas imagens iniciais e as tábuas genealógicas, no restante dos fólios, as imagens tomam as linhas de pautação escritural como parte delineadora de seus corpos pictóricos. Bandas de cor, bordas, ornamentos de estrela, entrelaços, tronos, asas de anjos, corpos de personagens, toda a anatomia da imagem toma de empréstimo as linhas de pauta para alinhar-se à página ou para atravessá-la, para conter-se no quadro de justificação ou para transbordá-lo intencionalmente.

Se texto e imagem fossem definidos pelo espaço (e não locus) que ocupam, todo os elementos visuais em páginas pautadas deveriam ser texto e em páginas sem pauta deveriam ser imagens. Quando retiramos a inflexibilidade dessa ordem, percebemos as contaminações dos lugares (estes sim como loci), em que o texto presente nas tábuas genealógicas pode ser imagem pela visibilidade de seu corpo, mas ainda é texto, mesmo que sem pauta; e o texto presente nas imagens com pauta ainda é texto, mas é também imagem. Os lugares ocupados por ambos podem ser de ordens diferentes, de lugares sutilmente apartados, sobre os quais possamos, a princípio, dizer "isto é pintura" e "isto é escrita", mas que mantém fronteiras

\footnotetext{
${ }^{353}$ Muitas vezes a estruturação dos estratos nas bandas de cor será guiada por relações hierárquicas próprias à narrativa cristã, em que Aquele que é o início e fim de tudo, Deus Todo Poderoso, deve estar sempre acima das outras coisas. Essa superioridade de importância faz com que o ornamento marque a imagem segundo as relações que ele estabelece entre os outros elementos e aquele que é o principal da narrativa. Pensemos se todas as nações figuradas nos ff. 147v-148 estivessem marcadas de vestes brancas, o Cordeiro deixaria de ser o único elemento "verdadeiramente" branco da imagem, ele perderia o posto de "maior luminosidade". Visualmente, ainda, o grupo de vestes brancas, por uma relação de contraste, viria para os primeiros planos da imagem, antes dos anjos, dos quatro viventes e, talvez, do Cordeiro.
} 
permissivas. "[...] há pintura, mesmo que sob uma forma atenuada, em toda escrita, e há escrita em toda pintura, mesmo que na simples repetitividade de seus signos". 354

A legibilidade da letra implica que ela tenha um corpo, e sua visualidade reclama a matéria da qual é construída. Ter um corpo implica em questões que vão além da legibilidade, estritamente, pois o corpo pictórico da letra envolve modos de funcionamento também pictóricos e, nesse sentido, falamos especificamente do trabalho do ornamento. O espaço textual, assim como o pictórico, é orquestrado pelos graus de aplicação do ornamento. Observemos como os títulos do prefácio, que dá nome à obra (f. 30), e do Comentário a Daniel (f. 267), são geridos pelo ornamento (Figura 42). Em um movimento de eco, ambos os títulos possuem estruturas similares - formados por uma letra capitular ornada em ouro e cores diversas, com as letras restantes do título escritas em ouro sobre bandas coloridas e uma letra capitular do início do texto.

A ornamentação também cria uma sutil distância qualitativa entre os dois títulos, na medida em que o título do Comentário ao Apocalipse possui maior concentração de uso de ouro, sobretudo nas duas iniciais, em detrimento da ausência de ouro na inicial "E" do título do Comentário a Daniel e no menor tratamento ornamental da primeira inicial, em comparação com a inicial "I" do primeiro título. Essa modulação intensifica o Comentário ao Apocalipse como a parte central da obra. Vemos também uma diferença na escala ornamental entre estes dois títulos e os títulos dos doze livros que compõem o Comentário ao Apocalipse.

\footnotetext{
${ }^{354}$ BOONE, Jean-Claude. Quelques remarques sur la lettre peinte dans la miniature romane. In: FERRIER. JeanLouis (ed.). La sociologie de l'art et sa vocation interdisciplinaire: l'oeuvre et l'influence de Pierre Francastel. Paris: Denoël/Gonthier, 1976, p. 182, tradução de Eduardo Henrik Aubert.
} 

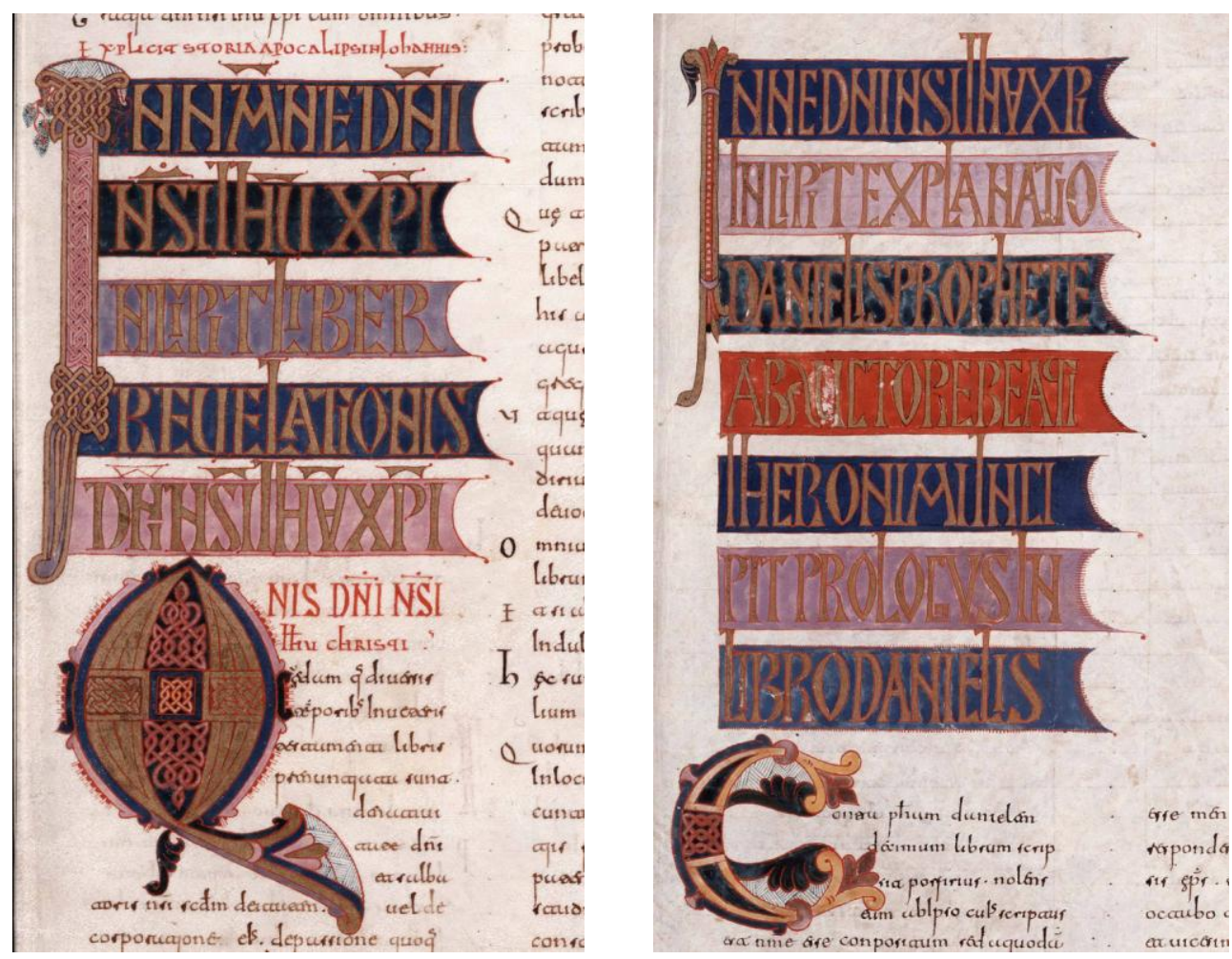

Figura 42. Beatus de Facundus, detalhes ff. 30, 267, títulos.

Fonte: www.bne.es (recorte da autora)

Estes títulos, bem como aqueles que iniciam e finalizam as storiae e as explanatios (incipit e explicit), são rubricas que, em maior ou menor grau de ornamentação, têm seu corpo evidenciado pela matéria do pigmento, que os distancia visualmente do restante do texto. Jean-Pierre Aniel diz que as relações mantidas entre as rubricas e os textos que acompanham são, a princípio, simples "[...] ela é responsável por nomear o autor e o título da obra ou uma de suas divisões (livro, capítulo), ou ela resume, em uma formulação mais ou menos longa, o conteúdo que se segue". ${ }^{355}$ No Beatus de Facundus, além das rubricas, existem os textos rubricados, sobretudo no corpo da explanatio, em que o fragmento da storia a ser explicado é marcado por cor vermelha, diferente do restante do texto da explanatio, que é em cor marrom escura.

Além do funcionamento ornamental das rubricas, no Beatus de Facundus, encontramos uma rubrica que recebe uma rubrica pictórica como meio de destacar parte do

\footnotetext{
${ }^{355}$ ANIEL, Jean-Pierre. La rubrique et l'image dans le manuscrit médiéval: quelques remarques. In: HECK, Christian (ed.). Qu'est-ce que nommer? L'image légendée entre monde monastique et pensée scolastique. (Actes du colloque du RILMA, Institut Universitaire de France, Paris, INHA, 17-18 octobre 2008). Turnhout, Belgium: Brepols, 2010, p.101. Mas há rubricas, segundo ele, que fornecem informações que não foram transcritas no texto ou mesmo explicações para a identificação de personagens nas imagens que não são facilmente reconhecíveis.
} 
texto como elemento visual. Trata-se do início da explanatio ao sétimo selo (Ap. 8, 1), em que a palavra silentium da rubrica é repetida de modo ornamental, em letras capitulares, em cor semelhante ao ouro, ornadas por uma espécie de borda vazada que divide a palavra em dois extratos: silen - tium. Essa divisão mostra que o corpo da letra é um ornamento que remete à palavra na rubrica. ${ }^{356}$ Além da forma monumental, a cromatização da palavra é um meio de dar corpo à letra. No título da interpretatio que figura a Arca de Noé, a palavra "qualiter" é ornada em vermelho (em "quali-") e em marrom escuro ("-ter"), seccionada em duas partes a fim de seguir o jogo cromático do título, na alternância de linha em cor vermelha e linha em cor marrom escuro. ${ }^{357}$
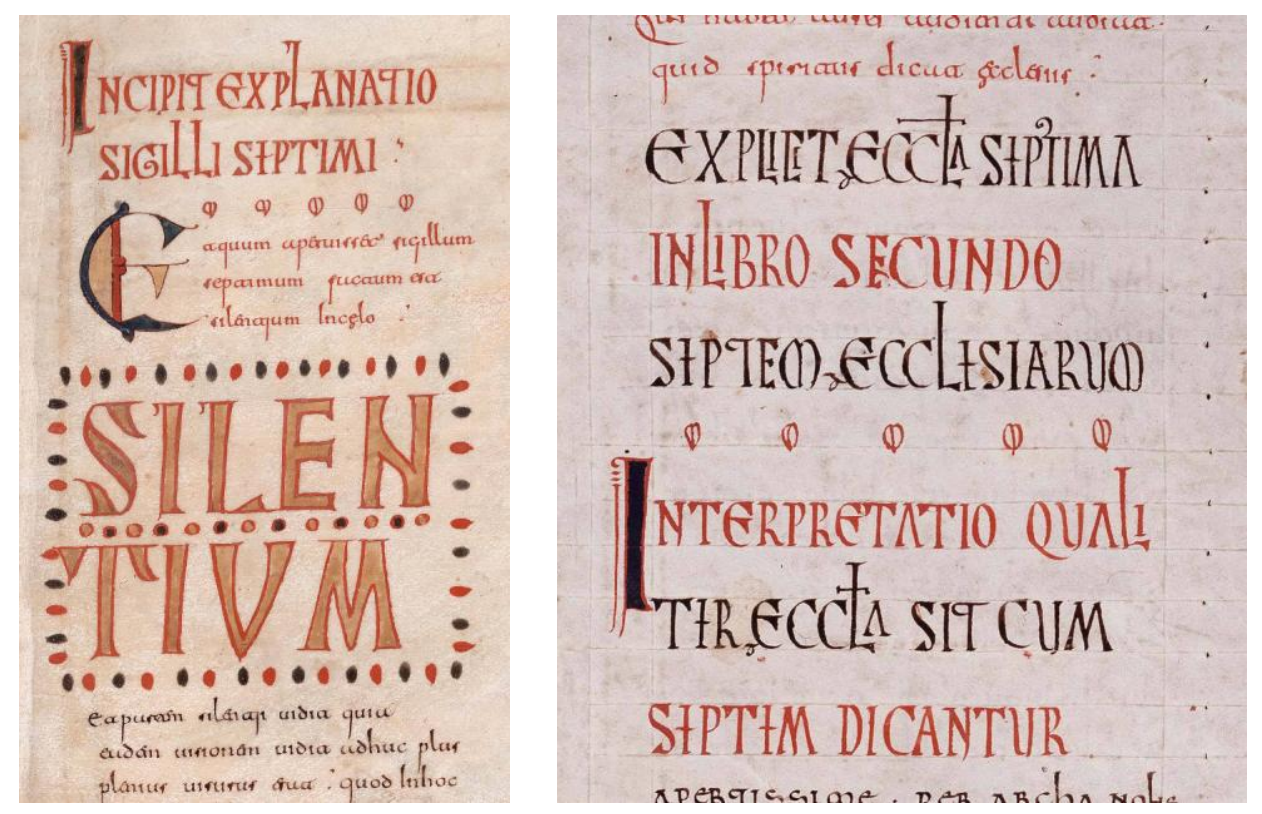

Figura 43. Beatus de Facundus, detalhes ff. 162, 108v, títulos.

Fonte: www.bne.es (recorte da autora)

As marcas plásticas e cromáticas ornamentais fazem com que a letra, por um lado, no espaço escritural, ganhe corpo pictórico, e, por outro, quando na imagem, a letra é pictórica com propriedades escriturais. Para referir-se às inscrições nas imagens, Charlotte Denoël prefere manter o termo titulus (ou tituli, no plural), para indicar sua abrangência para além de

\footnotetext{
${ }^{356}$ Sobre a imagem do silentium nos Beati, ver PRADO-VILAR, Francisco. Silentium: El silencio cósmico como imagen en la Edad Media y la Modernidad. Revista de poética medieval, 27, p. 21-43, 2013.

${ }^{357}$ A ornamentação em cor da palavra pode acompanhar a cromatização das imagens, quando palavra e imagem encontram-se na mesma página. Este é o caso das iniciais capitulares nos ff. 78, 82v, 87v, 92, 100v, 106v, aquelas sobre as quais nos dedicamos a analisar a variedade cromática no capítulo 4. Tal ocorrência é base para a continuidade deste estudo, dedicado, sobretudo, aos diálogos entre textos e imagem através da ornamentação.
} 
uma indicação descritiva (legenda). ${ }^{358}$ Os tituli são inscrições nas imagens e podem ser, segundo a autora, de três ordens: (i) tituli informativos, que indicam um nome, como no caso do f. 250v (Juízo Final), em que os tituli diferenciam o cherubin do seraphin, figurados de mesmo modo, como uma dobra; (ii) tituli descritivos, com os quais se descrevem uma ação ou qualquer outra relação com o texto do qual a imagem se origine, como no caso do f. 251 (Juízo Final), em que, na primeira banda de cor, a inscrição "isti sunt iudicati et damnati sunt copulati" indica, na imagem, aqueles que estão unidos e serão julgados e condenados; (iii) por fim, Denoël fala dos tituli diálogo, que são diálogos propriamente ditos entre os personagens, como no uso de filactérios. Essa última instância não está presente no Beatus de Facundus.

Tais instâncias podem não ser tão bem delimitadas na observância de suas funções, pois os tituli também são contextuais e dependem das mediações entre texto e imagem. Por exemplo, os tituli "ubi draco traxit angeli in infernum mittunt" e "diabolus ligatus in infernum tenetur", presentes no último estrato da imagem o f. 187 (A mulher vestida de sol e a serpetnte), falam de uma cena pictórica que não é descrita pelo texto, nem na storia e nem na explanatio. A cena, que diz que o anjo jogou o dragão no inferno, é a prefiguração da serpente acorrentada no f. 243v e do inferno do Juízo Final, ff. 250v-251. A presença dos dois tituli significa que nem sempre as inscrições provêm do texto, num sentido representativo e ilustrativo do que já foi dito, mas podem se mostrar como tituli indiciais, que indiciam algo que não foi dito anteriormente.

Outras vezes, até mesmo a instância dos tituli informativos pode ser mais complexa que uma simples repetição de nomes ou identificação de personagens já obviamente identificáveis. Se antes dissemos que Deus aparece nas imagens do Beatus de Facundus através de suas figuras, incluímos nesse crisol a figura que é também texto. O ornamento marca o titulus e faz com que a palavra tronus não seja apenas um titulus informativo, que dá nome a um objeto, no f. 182v. Mesmo que esse objeto seja identificado como o trono de Deus, pela presença figural daquele que o ocupa, a palavra tronus mostra-se como um ornamento de Deus, ou é uma figura de Deus, que trabalha pela dessemelhança (defiguratio).

Para Didi-Huberman, a dessemelhança é um poder da figura que separa "[...] a imitação que mente (imitação aparente) e a imitação que diz a verdade (imitação figural)", um poder que segue a seguinte ordem: "Afastar-te-ás do aspecto da coisa que queres

\footnotetext{
${ }^{358}$ DENOËL, Charlotte. Texte et image dans les Vies de saints à l'époque romane: le rôle des tituli et des légendes descriptives. In: HECK, Christian (ed.). Qu'est-ce que nommer? L'image légendée entre monde monastique et pensée scolastique. (Actes du colloque du RILMA, Institut Universitaire de France, Paris, INHA, 17-18 octobre 2008). Turnhout, Belgium: Brepols, 2010, p. 112-122.
} 
significar". ${ }^{359}$ Como figura, a palavra tronus ainda tem o poder do nome, da nominatio. Entende-se que "[...] o nome tem o poder de dar origem ao lugar, portanto à própria figura, que em muitos casos apenas glorifica, invoca ou desenvolve esse nome, como um tema na música". ${ }^{360}$ A palavra tronus reforça a presença de Deus na imagem e não é uma informação propriamente dita, como nas outras imagens em que a palavra tronus aparece em meio a uma ação a ser explicada ou indicada. ${ }^{361}$ Nesse caso, a palavra é um ornamento e figura de Deus. O titulus informativo pode assumir um papel ornamental que concatena relações entre as partes que ornamenta e faz com que, pela dessemelhança, o nome seja aderido a um lugar, pois "Como é que um desvio pelo dessemelhante pode estar presente, a não ser que emane a ideia de lugar fora de qualquer referência a um espaço natural?". Talvez não seja coincidência que a única palavra tronus escrita de modo solitário no Beatus de Facundus, sem a companhia de uma ação ou um corpo de difícil identificação que a justifique como descrição ou informação, seja ornada em cor branca sobre campo azul, semelhante à borda que orna o lugar celeste, ocupado por aquele que não é nomeado senão através de suas figuras.

Ainda sobre os poderes da figura, segundo Didi-Huberman, ela também trabalha através da virtus, do virtual, "[...] um sistema em que cada figura nunca se deixa reconhecer a si própria sob o seu verdadeiro rosto. Para isso ela precisa da potencialidade de todas as outras.". ${ }^{362}$ Trata-se de potencialidades atualizadas dentro das referências de uma imagem a outra. Diante do exposto, nos perguntamos se não seria o ornamento aquele que, no Beatus de Facundus, gere o virtus da figura e permite que ela funcione de diferentes modos, a depender de quais engrenagens são acionadas.

359 DIDI-HUBERMAN, Georges. Poderes da figura. Exegese e visualidade na Arte Cristã. Revista de Comunicação e Linguagens. n. 20, p. 159-177, 1994, p. 171.

360 DIDI-HUBERMAN, Georges. Poderes da figura. Exegese e visualidade na Arte Cristã. Revista de Comunicação e Linguagens. n. 20, p. 159-177, 1994, p.173

${ }^{361}$ Como no f. 238, em que o titulus "ubi quattuor animalia et seniores adorant tronum" (onde havia quatro viventes e anciãos adorando o trono) aparece no primeiro estrato da imagem como figura de "então os vinte e quatro anciãos e os quatro viventes se prostraram e adoraram a Deus, que está sentado no trono, dizendo, Amém! Aleluia!" (Ap. 19, 4). CAMPO HERNÁNDEZ, Alberto del; FREEMAN, Leslie G.; GONZÁLEZ ECHEGARAY, Joaquín (ed.). Beato de Liébana. Obras completas y complementarias. Edição bilíngue do latim ao castelhano. Madrid: Biblioteca de Autores Cristianos, 2004, v. 1, p. 578-579.

362 DIDI-HUBERMAN, Georges. Poderes da figura. Exegese e visualidade na Arte Cristã. Revista de Comunicação e Linguagens, n. 20, p. 159-177, 1994, p. 170. 


\title{
6 CONSIDERAÇÕES DO FIM EM ETERNO ACONTECIMENTO
}

\begin{abstract}
Termina o códice do Apocalipse com o número de uma dúzia de Igrejas. Da mesma maneira, distribuído por seções seguindo a ordem de doze livros, é um códice de muitos livros e é um livro de um só volume; e se chama códice pelo simbolismo com as cascas das árvores ou de videiras, a semelhança de um tronco de árvore que sustenta vários livros, como ramos. O livro é chamado de volume por estar enrolado; assim o é, por exemplo, para os hebreus o volume da Lei, os volumes dos Profetas. As folhas dos livros assim se chamam ou por semelhança com as folhas das árvores ou porque se fazem os livros de "fuelles", quer dizer, de peles, que em geral são extraídas de carneiro, uma vez sacrificado, cujas faces se chamam páginas, pelo fato de que se juntam umas com as outras. Termina em nome de nosso Senhor Jesus Cristo. $^{363}$
\end{abstract}

Essas são as palavras com as quais Beato de Liébana finaliza sua obra. Diante de tal declaração, somos levados a crer que, desde a sua nascente, o Beatus de Facundus deixa brotar o interesse em compreender o que é um manuscrito medieval como objeto. Desse brotamento florescem mil possibilidades. A uma dessas flores, chamamos de ornamento. As camadas de pétalas que ornam o Beatus de Facundus estruturam a sua objetidade, o seu jeito de ser um objeto.

As metáforas, analogias e análises aqui presentes, pintam o panorama desfocado das teorias do ornamento com cores mais vivazes. Tomamos nossa paleta para esboçar o potencial do ornamento na imagem medieval.

Se nosso trabalho parte do corpo do manuscrito, de seus fólios e cadernos, é para colocarmos a matéria a serviço da imagem e de suas ferramentas. Encontramos nas camadas mais carnais da imagem a substância para seu agenciamento na cultura medieval. A imagem

\footnotetext{
${ }^{363 "}$ Explicit codex Apocalipsin duodenario ecclesiarum numero. Ita duodenario ordine librorum incisione distincto, codex multorum librorum est et liber est unius voluminis; et dictus codex per translationem a corticibus arborum seu vitium, quasi caudex, quod ex multitudinem librorum, quasi ramorum contineat. Volumen liber est a volvendo dictus, sicut apud hebraeus volumen legis, volumina prohetarum. Foliae autem librorum appellatae sive ex similitudine foliorum arborum seu quia ex follibus fiunt, id est, ex pellibus, quibus occisis pecoribus detrahi solent, cuius partes paginae dicuntur, eo quod sibi invicem compinguntur. Explicit in nomine Domini nostri Iesu Christi". CAMPO HERNÁNDEZ, Alberto del; FREEMAN, Leslie G.; GONZÁLEZ ECHEGARAY, Joaquín (ed.). Beato de Liébana. Obras completas y complementarias. v. 1. Edição bilíngue do latim ao castelhano. Madrid: Biblioteca de Autores Cristianos, 2004, p. 640-641, tradução nossa. Nesta compilação de fechamento do Comentário ao Apocalipse, nos ff. 263v-264, Beato de Liébana utiliza, em grande parte, a obra de Isidoro de Sevilha - "Etimologias" Livro 6, capítulo 13, o que cria uma ligação com a próxima parte da obra, o tratado De adfinitatibus et Gradibus, uma adaptação de "Etimologias" 9, 5. Beato de Liébana coloca, em sua última fala, a materialidade do manuscrito em diálogo com as palavras contidas no livro. São doze os livros que compõem sua obra, assim como são doze os apóstolos que saciam, através da predicação da palavra, os povos consumidos pela fome, segundo Beato de Liébana na explanatio anterior ao fechamento. De mesmo modo que a árvore da vida dá frutos doze vezes, em cada um dos meses, o livro fornece alimento espiritual para todo o tempo.
} 
medieval necessita que seu corpo e as ações por ela praticadas, seus poderes, sejam contíguos, que não se apartam em defesa de uma visão que privilegie apenas uma de suas partes constituintes. O ornamento é uma engrenagem que mantém corpo e trabalho em constante movimento, porque uma imagem medieval para existir, precisa funcionar.

Temos comparado esse conjunto de imagens medievais, que formam o objeto, com uma máquina. Essa imagem-objeto funciona de um modo maquínico, ela executa trabalhos com suas devidas ferramentas. Assim como um ser humano vivo é um ser humano, e um ser humano morto é um cadáver, uma máquina que não funciona é, também, um cadáver. A imagem pode morrer, ou ao menos, transformar-se. Sistema, organismo, máquina, abraço, são meios de dizer que a ideia de imagem medieval é uma construção nitidamente teórica. Temos, diante de nós, os corpos que denunciam o que teria sido a imagem medieval, mas estes documentos funcionam, hoje, por outros meios, de modo interpretativo e construtivo (inventio). Descobrir a datação que coloca o objeto em um tempo específico não o torna ainda uma imagem medieval, pois essa imagem funciona através de uma complexa rede ritualística, da qual pouco podemos acessar, salvo pela construção teórica. Através da pesquisa, conseguimos construir uma abstração, a qual chamamos de imagem medieval. Nessa abstração, forma, função e conceitos, como o de ornamental e ornamentalidade, são colocados para falar dos modos com que o ornamento orquestra a imagem medieval. É essa orquestração que a permite funcionar continuamente, embora de maneira potencial.

Dentro desses modos de trabalho, o ornamento toma posse de toda a matéria do objeto que orna. Ele não será apenas aquele elemento formal bem localizado no campo da História da Arte, mas um modo próprio de trabalho da imagem medieval. É pela ação de um elemento na imagem que podemos distingui-lo como ornamento, ou seja, tudo aquilo que funciona como uma beleza honorífica, a princípio, mas que passa a assumir outras funções, a depender das exigências da imagem. Nesse sentido, as cores ganham um papel importante no funcionamento da imagem medieval. A cor-ornamento é aquela que pode ter função iconográfica, simbólica ou estar a serviço de uma beleza por sua variedade cromática, mas que, como ornamento, não se limita a esses sentidos. Pensar a cor-ornamento, dentro de um sistema complexo de engrenagens, é colocá-la a serviço da estrutura da imagem, que agencia os lugares e as hierarquias. No interior dessa organização, as cores dialogam entre si e marcam lugares a serem habitados, como o lugar do Cristo, que existe por indício do ornamento. O ornamento gere os lugares da imagem e a honra que dele provém cria outros 
sentidos, que não os iconográficos e do plano teológico e espiritual, mas que falam do próprio corpo da imagem.

As cores trabalham de modo sutil. Elas têm um grande alcance perceptivo, mas seu trabalho é quase imperceptível, pois está sempre associado a outros elementos da imagem. As cores ocupam e atravessam toda a imagem, e por isso tendem a ser confundidas com um preenchimento. Uma coisa é sutil quando sua complexidade cria uma variada rede dialógica entre todas as peças que a compõem e essas relações são tão fundamentais que a retirada de uma peça afeta toda a economia. Se retirar uma cor, o sistema está desfeito.

Essa rede dialógica, criada pelas cores, e pelo ornamento de um modo geral, faz com que um elemento se reporte a outro. O diálogo não está na aparência, mas na relação, no modo com que duas imagens diferentes se reconhecem. Se, no texto do Apocalipse, recorre-se a constantes recapitulações e relações de reconhecimento, nas imagens do Beatus de Facundus não é tão diferente. $\mathrm{O}$ ornamento orquestra a imagem, compõe sua estrutura de modo com que o tempo seja suspenso, que as imagens permaneçam em eterno acontecimento. Uma imagem leva à outra e à outra e à outra, sucessivamente, até percebermos que a primeira imagem é semelhante à última e que elas funcionam de modo apocalíptico. O Apocalipse não se encerra, mas desde o início mantém um constante final, aquele da espera do fim iminente. De modo semelhante, o ornamento trabalha nas imagens para que elas sejam o eterno acontecimento da espera do Fim do Mundo. 


\section{REFERÊNCIAS}

ALOFSIN, Anthony. Frank Lloyd Wright, the Lost Years, 1910-1922: A Study of Influence. Chicago: University of Chicago Press, 1994.

ÁLVAREZ CAMPOS, Sergio. Fuentes literarias de Beato de Liébana. Actas del simposio para el estudio de los códices del Comentario al Apocalipsis de Beato de Liébana. Madrid: Joyas bibliográficas, 1979, v. 1, p. 119-162.

ALVEMY, Marie-Thérèse. Le cosmos symbolique du XII ${ }^{\mathrm{e}}$ s. Paris: Archives d'histoire doctrinale et littéraire du Moyen Âge, 1953, p. 31-81.

AMALVI, Christian. Idade Média. In: LE GOFF, Jacques; SCHMITT, Jean-Claude. Dicionário temático do Ocidente medieval. V. 1. Bauru/São Paulo: EDUSC/Imprensa Oficial, 2002, p. 537-551.

ANIEL, Jean-Pierre. La rubrique et l'image dans le manuscrit médiéval: quelques remarques. In: HECK, Christian (ed.). Qu'est-ce que nommer? L'image légendée entre monde monastique et pensée scolastique. (Actes du colloque du RILMA, Institut Universitaire de France, Paris, INHA, 17-18 octobre 2008). Turnhout, Belgium: Brepols, 2010, p. 101-110.

ARNALDI, Francesco et al. Ornamentum In: Novum Glossarium Mediae

Latinitatis. Copenhague: Munksgaard, fascículo Ordior-Oz, 1983-2011. Disponível em: <http://scriptores.pl/ngml/view?docId=Ordior-Oz/Ordior-Oz.xml>. Acesso em: 15 jun. 2014.

ARRUDA, Francimar Duarte. A questão do imaginário: a contribuição de Sartre. Em Aberto, Brasília, ano 14, n.61, p.78-85, jan./mar. 1994.

AUERBACH, Erich. Figura. São Paulo: Ática, 1997 (série Temas, v.62).

BANGO TORVISO, Isidro G., La piedad de los reyes Fernando I y Sancha. Un tesoro sagrado que testimonia el proceso de renovación de la cultura hispana del siglo XI. In: . (coord.) Maravillas de la España medieval. Tesoro sagrado y monarquía, tomo I. Leão-Espanha: Junta de Castilla y León, 2001.

BASCHET, Jérôme. Introdução à imagem-objeto. In: ; SCHMITT, Jean-Claude (orgs.). L'image. Fonctions et usages des images dans l'Occident médiéval. Paris: Le Léopard d'Or, 1996, p. 7-26. Tradução: Maria Cristina C. L. Pereira.

Inventivité et sérialité des images médiévales. Pour une approche iconographique élargie. Annales. Histoire, Sciences Sociales. 51e année, n. 1, p. 93-133, 1996.

L'iconographie médiévale. Paris: Gallimard, 2008.

BÍBLIA. Português. Bíblia de Jerusalém. São Paulo: Paulus, 2010.

BISCHKO, Charles J. Fernando I y Cluny CHE, XLVII-XLVIII, 1968, pp. 31-135 e XLIX-L, p. 50-156, 1969. 
. J. Fernando I y los orígenes de la alianza castellano-leobesa con Cluny. Cuadernos de Historia de España, XLVII-XLVIII, p. 35-135, 1968.

BOLMAN, Elizabeth S. De coloribus: the meanings of color in Beatus manuscripts. Gesta, vol. 38, no. 1, p. 22-34, 1999.

BONNE, Jean-Claude. Quelques remarques sur la lettre peinte dans la miniature romane. In: FERRIER. Jean-Louis (ed.). La sociologie de l'art et sa vocation interdisciplinaire: l'oeuvre et l'influence de Pierre Francastel. Paris: Denoël/Gonthier, 1976 (tradução de Eduardo Henrik Aubert).

Fond, surfaces, support. Panofsky et l'art roman. In: et al. Erwin

Panofsky. Paris: Centre Georges Pompidou/Pandora, 1983, p. 117-134.

L'art Roman de face et de profil: Le tympan de Conques. Paris: Le Sycomore, 1984.

Syntaxe. In: L'art Roman de face et de profil: Le tympan de Conques. Paris: Le Sycomore, 1984, p.183-200.

À la recherche des images médiévales. Annales. Économies, Sociétés, Civilisations, 46 année, n. 2, p. 353-373, mar.-abr. 1991. Disponível em: <www.persee.fr/doc/ahess_03952649_1991_num_46_2_278951>. Acesso em: 23 nov. 2015.

De l'ornemental dans l'art médiéval (VIIè - XIIè siècle): Le modele insulaire. In: SCHMITT, Jean-Claude; BASCHET, Jérôme (orgs). L'image: Fonctions et usages des images dans l'Occident médiéval. Paris: Le Léopard d'Or, 1996, p. 207-249.

Les ornements de l'histoire (à propos de l'ivoire carolingien de Saint Remi). Annales Histoire, Sciences Sociales, 51'e année, n. 1, p. 37-70, jan/fév. 1996. Disponível em: <www.persee.fr/doc/ahess_0395-2649_1996_num_51_1_410833>. Acesso em: 15 out. 2015

Repenser l'ornement, repenser l'art médiéval. Actes du Colloque International,: Le rôle de l'ornement dans la peinture murale du Moyen Âge. Saint-Lizier, 1-4 juin 1995. Poitiers: Université de Poitiers, 1997, p. 217-220.

De l'ornement à l'ornementalité: La mosaïque absidiale de San Clement de Rome. Actes du Colloque International: Le rôle de l'ornement dans la peinture murale du Moyen Âge. Saint-Lizier, 1-4 juin 1995. Poitiers: Université de Poitiers, 1997, p.103-119.

. "Relève" de l'ornementation celte païnne dans un évangile insulaire du VIIe siècle (Les Evangiles de Durrow)". Actes de Ideologie e Pratiche del Reimpiego nell'Alto Medioevo. Espoleto, Itália: Centro Italiano di Studi sull'Alto Medioevo, 1999, v.2, p. 10111054.

Penser en couleur: à propôs d'une apocalyptique du X siècle. In: SCHMITT, JeanClaude; HÜLSEN-ESCH, Andrea von (Org). Die Methodik der bildinterpretation / Les méthodes de l'interpretation de l'image. Deutsch-französische Kolloquium 1998-2000. Göttingen: Max-Planck Institut für Geschichte, 2002, 2 v. p.355-379.

et al. Y a-t-il une lecture symbolique de l'ornement? Perspective, $1 \mid 2010,27-42$, p.

33. Disponível em: <http://perspective.revues.org/1206>. Acesso em: 11 dez. 2015. 
BOYNTON, Susan; REILlY, Diane J. (ed.). The Practice of the Bible in the Middle Ages: Production, Reception, and Performance in Western Christianity. New York: Columbia University Press, 2011.

BROWN, Michelle. Understanding Illuminated Manuscripts: a Glossary of Technical Terms. London/Malibu: British Library/J. Paul Getty Museum, 1994.

BUTTERWORTH, Alex; LAURENCE, Ray. Pompeia: A cidade viva. Rio de Janeiro: Record, 2007.

CAMPO HERNÁNDEZ, Alberto del; FREEMAN, Leslie G.; GONZÁLEZ ECHEGARAY, Joaquín (ed.). Beato de Liébana. Obras completas y complementarias. v. 1. Edição bilíngue do latim ao castelhano. Madrid: Biblioteca de Autores Cristianos, 2004.

CARRUTHERS, Mary. The Medieval Craft of Memory: An Anthology of Texts and Pictures. Estados Unidos: University of Pennsylvania Press, 2002.

. A técnica do pensamento: meditação, retórica e a construção de imagens (4001200). Campinas, SP: Unicamp, 2011.

CHARTIER, Marie-Christine. Présence de la Bible dans les règles et coutoumiers. In : RICHÉ, Pierre.; LOBRICHON, Guy (ed). Le moyen age et le Bible. Paris: Beauchsne, 1984, p. 305-324.

CHRISTE, Yves. The Apocalypse in the monumental art of the eleventh through thirteen centuries. In : MCGINN, Bernard; EMMERSON, Richard K. The Apocalypse in the Middle Ages. Ithaca: Cornell University Press, 1992.

CLEMENS, Raymond; GRAHAM, Timothy. Introduction to Manuscript Studies. Ithaca: Cornell University Press, 2008.

COURTINE, Jean-Jacques; MARANDIN, Jean-.Marie. Quel objet pour l'analyse du discours? in Matérialités discursives. Lille: Presses Universitaires de Lille, 1981, p. 21-35.

CUESTA, J.; GONZÁLEZ, R.; BOLADO, Mª C.; Monasterios medievales de Liébana. Clavis. Boletín del Museo Diocesano de Santillana del Mar, n.1, p. 8-97, 1996.

DALARUN, Jacques (dir.). Le Moyen Âge en lumière: Manuscrits enluminés des bibliothèques de France. Paris: Fayard, 2002.

DAMISCH, Hubert. Ornamento. In: Enciclopedia Einaudi. Lisboa: Casa da Moeda, 1995, v. 32, p. 323-331.

DE HAMEL, Christopher. Scribes and Illuminators. Toronto: University of Toronto Press, 1992.

DEBRAY, Regis. Vida e morte da imagem: uma história do olhar no ocidente. Petrópolis, RJ: Vozes, 1994.

DENOËL, Charlotte. Texte et image dans les Vies de saints à l'époque romane: le rôle des tituli et des légendes descriptives. In: HECK, Christian (ed.). Qu'est-ce que nommer? L'image légendée entre monde monastique et pensée scolastique. (Actes du colloque du 
RILMA, Institut Universitaire de France, Paris, INHA, 17-18 octobre 2008). Turnhout, Belgium: Brepols, 2010, p. 112-122.

DÍAZ Y DÍAZ, Manuel Cecilio. La tradición del texto de los Comentarios al Apocalipsis. Atas do Simpósio para o estudo dos códices do Comentário ao Apocalipse de Beato de Liébana. Madrid, 1978, p.163-184.

DIDI-HUBERMAN, Georges. Poderes da figura. Exegese e visualidade na Arte Cristã. Revista de Comunicação e Linguagens, n. 20, p. 159-177, 1994.

O que vemos, o que nos olha. Tradução Paulo Neves. São Paulo: Ed. 34, 1998.

Quando as imagens tocam o real. Tradução de Patrícia Carmello e Vera Casa Nova. Pós: Belo Horizonte, v. 2, n. 4, p. 204 - 219, nov. 2012.

Diante da imagem: questões colocadas aos fins de uma história da arte. São Paulo: Editora 34, 2013.

DODWELL, C. R. (ed. trad.). Theophilus: The Various Arts. Londres-New York, 1961

ECO, Umberto. Como se faz uma tese em ciências humanas. Lisboa: Editorial Presença, 2007.

A memória vegetal: e outros escritos sobre bibliofilia. Rio de Janeiro: Record, 2010.

EGRY, Anne de. Um estudo de O Apocalipse do Lorvão e a sua relação com as ilustrações medievais do Apocalipse. Lisboa: Fundação Calouste Gulbenkian, 1972.

ESCOLAR, Hipólito. Los manuscritos: historia ilustrada del libro español. Madrid: Fundación Germán Sánchez Ruipérez, 1996.

FADIMAN, Anne. Ex-libris: confissões de uma leitora comum. Rio de Janeiro: Jorge Zahar, 2002.

FAVORETO, Fabiana P. Beatus de Fernando I e Sancha: símbolo de poder e riqueza na Espanha do século XI. Anais eletrônicos do III Congresso Internacional Ufes/Université Paris-Est/Universidade do Minho: territórios, poderes, identidades (Territoires, pouvoirs, identités). Vitória: GM, 2011, p. 1-12.

; PEREIRA, Maria Cristina C. L. Beatus de Facundus: um estudo da ornamentalidade das cores. Anais do XIII Congresso Internacional de Filosofia Medieval. Vitória: UFES, 2011.

FEBVRE, L; MARTIN, HJ. O aparecimento do livro. Lisboa: Fundação Calouste Gulbenkian, 2000.

FLETCHER, Richard A. Reconquest and Crusade in Spain. Royal Historical Society, v. 37, série 5, p. 31-47, 1987. Disponível em:

$<$ http://roberthaug.files.wordpress.com/2013/08/fletcher-reconquest-and-crusade-inspain.pdf>. Acesso em: 20 mar. 2014. 
FLÓREZ, Henrique (ed.). Viage de Ambrosio de Morales por orden del rey D. Felipe II a los reinos de León y Galicia y principado de Asturias para reconocer las reliquias de santos, sepulcros reales y libros manuscritos de las catedrales y monasterios. Madri: Antonio Martin, 1765.

FLORIÊNSKI, Pável. A perspectiva inversa. São Paulo: 34, 2012.

FLÜSSER, Vilém. O Universo das Imagens Técnicas: Elogio da Superficialidade. São Paulo: Anna-blume, 2008.

A escrita: há futuro para a escrita? São Paulo: Annablume, 2010.

FONTAINE, Jacques. El Mozárabe. Madrid: Encuentro, 1984.

Isidoro de Sevilla. Génesis y originalidad de la cultura hispánica en tiempos de los visigodos. Madrid: Ediciones Encuentro, 2002.

FOUCAULT, Michel. Isto não é um cachimbo. Tradução Jorge Coli. Rio de Janeiro: Paz e terra, 1988.

FOURNIER, Sylvie. Brève histoire du parchemin et de l'enluminure. Paris: Éditions Fragile, 1995.

FRANCO JR., Hilário. O ano 1000: Tempo de medo ou de esperança. São Paulo: Companhia das letras, 1999.

. Modelo e imagem: o pensamento analógico medieval. Bucema. Bulletin du centre d'études médiévales d 'Auxerre, Hors-série n.2, 2008. Disponível em:

<http://cem.revues.org/9152>. Acesso em: 06 jan. 2016.

FREEMAN, Leslie G. Elementos simbólicos en la obra de Beato. In: CAMPO HERNÁNDEZ, Alberto del; FREEMAN, Leslie G.; GONZÁLEZ ECHEGARAY, Joaquín (ed.). Beato de Liébana. Obras completas y complementarias. Edição bilíngue do latim ao castelhano. Madrid: Biblioteca de Autores Cristianos, 2004, v. 1, p. XXXIII-XLVII.

GAGE, John. Color and Culture: Practice and Meaning from Antiquity to Abstraction. Califórnia: University of California Press, 1999.

GARCÍA GALLO, Alfonso. El Concilio de Coyanza. Contribución al estudio del Derecho canónico español en la Alta Edad Media. A.H.D.E., v. XIX-XX, p. 257-633, 1951.

GÉHIN, Paul (org.). Lire le manuscrit médiéval: observer et décrire. Paris: Armand Colin, 2005.

GONZÁLEZ ECHEGARAY, Joaquín. Beato de Liébana y los terrores del año 800. Atas IX Semana de Estudios Medievales: Milenarismos y milenaristas en la Europa medieval. Nájera, 1998, p. 87-100. Disponível em: 〈http://dialnet.unirioja.es/servlet/articulo?codigo=563027>. Acesso em: 28 out 2014.

Los Códices. CAMPO HERNÁNDEZ, Alberto del; FREEMAN, Leslie G.; GONZÁLEZ ECHEGARAY, Joaquín (ed.). Beato de Liébana. Obras completas y 
complementarias. Edição bilíngue do latim ao castelhano. Madrid: Biblioteca de Autores Cristianos, 2004, v. 1, p. XXV-XXXII.

Beato de Liébana y su mundo. In: WILLIAMS, John et al. Beato de Fernando I y Sancha. Barcelona: M. Moleiro, 2006, p. 13-30.

GRABAR, André. Los orígenes de la estética medieval. Madrid: Siruela, 2007.

GRABAR, Oleg. The Mediation of Ornament. Estados Unidos: Princeton, 1992.

De l'ornement et de ses définitions. Perspective, n. 1, 2010, p. 5-7. Disponível em: <http://perspective.revues.org/1195>. Acesso em: 10 jan. 2016.

GROS, Pierre. La notion d'ornamentum de Vitruve à Alberti. Perspective, n. 1, p. 130-136, 2010. Disponível em: <http://perspective.revues.org/1226 >. Acesso em: 23 nov. 2015.

GUERREAU, Alain. Feudalismo. In: LE GOFF, Jacques; SCHMITT, Jean-Claude. Dicionário temático do Ocidente medieval. V. 1. Bauru/São Paulo: EDUSC/Imprensa Oficial, 2002, p. 437-455.

GUINEA, Juan Carlos Elorza (dir.). Caminhos de Santiago: Arte no período românico em Castela e Leão, Espanha (séc. XI ao XIII) São Paulo: Junta de Castilla y León, Instituto Inclusartiz, 2007.

GUINEA, Miguel Ángel G.; GONZÁLEZ, José María Pérez. (ed.) Enciclopedia del Románico en Castilla y León. Santander: Fundación Santa Maria la Real. Centro de Estudios del Románico, 2002.

HAEBLER, Claus. Kosmos: Eine etymologisch-wortgeschichtliche Untersuchung. Archiv für Begriffsgeschichte, n.11, p. 101-118, 1967.

HALSALL, Paul. Glossary of Terms Used in Paleography: preliminary version 0.2. In:

Byzantium: The Byzantine Studies on the Internet. New York: Fordham University,

21 out. 1996. Disponível em: <http://www.fordham.edu/halsall/byz/paleoggloss.html>. Acesso em: 19 out. 2014.

HECK, Christian (ed.). Qu'est-ce que nommer? L'image légendée entre monde monastique et pensée scolastique. (Actes du colloque du RILMA, Institut Universitaire de France, Paris, INHA, 17-18 octobre 2008). Turnhout, Belgium: Brepols, 2010.

HERNANDO, Irene González. El tetramorfo. Revista Digital de Iconografoa Medieval, vol. III, n.5, 2011, p.61-73. Disponível em: <https://www.ucm.es/data/cont/docs/621-2013-11-218.\%20Tetramorfo.pdf $>$. Acesso em: 14 jul 2014

JONES, Owen. The Grammar of Ornament. Londres: Cary Collection, Rochester Institute of Technology, 1856.

KLEIN, Peter. La tradición pictórica de los Beatos. Actas del Simpósio para el Estudio de los Códices del "Comentario al Apocalipsis" de Beato de Liébana, v. 2, Madrid: Joyas Bibliográficas, 1980, p. 83-106. 
Introduction: The Apocalypse in Medieval Art. In: MCGINN, Bernard; EMMERSON, Richard K.. (orgs). The Apocalypse in the Middle Ages. Ithaca: Cornell University Press, 1992, p. 159-199.

Beato de Liébana: la ilustración de los manuscritos de Beato y el Apocalipsis de Lorvão, trad. Beatriz Mariño. Valência: Patrimonio Ediciones, 2004.

LABARRE, Albert. História do Livro. Lisboa: Livros Horizonte, 2005.

LAUWERS, Michel. Le cimetière dans le Moyen Age latin: Lieu sacré, saint et religieux. Annales. Histoire, Sciences Sociales, 54e année, n. 5, pp. 1047- 1072, Sep. - Oct. 1999.

LE GOFF, Jacques. Uma longa Idade Média. Rio de Janeiro: Civilização Brasileira, 2008. ; SCHMITT, Jean-Claude. Dicionário temático do Ocidente medieval. V. 1. Bauru/São Paulo: EDUSC/Imprensa Oficial, 2002.

LELIÈVRE, Valérie. La page: entre texte et livre In: MILON, Alain; PERELMAN, Marc (eds.). Le livre et ses espaces. Nanterre: Presses universitaires de Paris Ouest, 2007. Disponível em: <http://books.openedition.org/pupo/486>. Acesso em: 10 ago 2014.

LLUCH, Mónica Castillo. Sobre el concepto de manuscrito original en la teoría filológica. Pandora: revue d'etudes hispaniques, n³, 2003, p.45-54. Disponível em: $<$ http://dialnet.unirioja.es/servlet/autor?codigo=512195>. Acesso em: 15 ago 2014.

LYOTARD, Jean-François. Discurso, figura Buenos Aires: Ediciones La Cebra, 2014.

MANSO MARTÍN, Esperanza; SÁNCHEZ-RUBIO, María Ascensión S. Orígenes y fuentes de la iconografía del Tetramorfos en la pintura románica castellano-leonesa. Cuadernos de Arte e Iconografia, tomo II, $\mathrm{n}^{\circ} 3$, 1989, pp. 110-116. Disponível em: <http://www.fuesp.com/revistas/pag/cai0314.html>. Acesso em: 10 jul 2014.

MARTIN, Henri-Jean; VÉZIN, Jean (eds.). Mise en page et mise en texte du livre manuscrit. Paris: Promodis, 1990.

MCGINN, Bernard. Introduction: John's Apocalypse and the Apocalyptic mentality. In: ; EMMERSON, Richard K (orgs.). The Apocalypse in the Middle Ages. Ithaca: Cornell University Press, 1992, p. 3-19.

MENDONÇA, Carlos V. C. de; ALVES, Gabriela S. Da alegria e da angústia de diluir fronteiras entre a história e a literatura. Revista Cantareira, v. 3, p. 1-16, 2013. Disponível em: 〈http://www.historia.uff.br/cantareira/v3/wp-content/uploads/2013/05/e04a02.pdf>. Acesso em: 15 abr. 2015.

MENESES, Ulpiano T. Bezerra de. A história, cativa da memória? Para um mapeamento da memória no campo das ciências sociais. Revista do Instituto de Estudos Brasileiros, n. 34, 1992.

MINDLIN, José. Uma vida entre livros: reencontros com o tempo. São Paulo: Universidade de São Paulo, 2008. 
MORALES, Ambrosio de. Los cinco libros postreros de la Crónica general de España. Córdoba: 1586, ff. 43-47 Cano, 1791.

Crónica general de España, Tomo VII. Madri: edição da oficina de Don Benito

MUNDÓ, Anscari; SÁNCHEZ MARIANA, Manuel. El comentario de Beato al Apocalipsis: catálogo de los códices. Madri: Biblioteca Nacional, 1976.

MUZERELLE, Denis Vocabulaire codicologique: répertoire méthodique des termes français relatifs aux manuscrits. Paris: Ed. CEMI, 1985, p. 265. Disponível em:

<http://vocabulaire.irht.cnrs.fr>. Acesso em: 19 out. 2014.

NAVARRO, P. (Org.). Texto e discurso. São Carlos: Claraluz, 2006.

NEUSS, Wilhelm. Die Aokalypse des Hl. Johannes in der altspanischen Bibel-

Illustration: Das Problem der Beatus Handschriften. 2 v. Alemanha: Bonn-Münster, 1931.

NIERMEYER, J.F; KIEFT, C.V. Medieval Latin Dictionary. Leiden: Brill, 2002.

NOCK, Frances Clare (ed. trad.). Frutuoso de Braga. The Vita Sancti Fructuosi.

Washington: The University of America Press, 1946.

NORA, Pierre (org). Les lieux de mémoire. Paris: Gallimard, 2008.

OAKESHOTT, Walter. The Artists of the Winchester Bible. London: Faber and Faber, 1945.

PÄCHT, Otto. La miniatura medieval: una introducción. Madrid: Alianza, 1987.

PAIM, Gilberto. A beleza sob suspeita: o ornamento em Ruskin, Lloyd Wright, Loos, Le Corbusier e outros. Rio de Janeiro: J. Zahar, 2000

PALAZZO, Éric. Le livre dans les trésors du Moyen Âge. Contribution à l'histoire de la Memoria médiévale. Annales. Histoire, Sciences Sociales. 52e année, n. 1, p. 93-118, 1997.

PANOFSKY, Erwin. A perspectiva como forma simbólica. Lisboa: Ed.70, 1993.

PAOLETTI, Jo Barraclough. Pink and Blue: Telling the Girls From the Boys in America. Indiana, USA: Indiana University Press, 2012.

PASTOUREAU, Michel. Dicionário das cores do nosso tempo: simbólica e sociedade. Lisboa: Estampa, 1997.

Símbolo. In: LE GOFF, Jacques; SCHMITT, Jean-Claude. Dicionário temático do

Ocidente medieval. São Paulo: Edusc/Imprensa Oficial, 2002, v. 2, p. 495-510.

Una historia simbólica de la Edad Media occidental. Buenos Aires: Katz, 2006.

Bleu: Histoire d'une couleur. Paris: Seuil, 2006. 
2006.

; SIMONNET, Dominique. Breve historia de los colores. Barcelona: Paidós Ibérica,

PEDRONI, Fabiana. Por uma definição do ornamento. Anais do IX Encontro de História da Arte - Circulação e trânsito de imagens e ideias na História da Arte. Campinas, SP: Unicamp, 2013. p. $80-85$.

Sobre a ornamentalidade medieval: estudo do fólio 112v do Beatus de Facundus.

História e Cultura, v. 2, p. 380-393, 2013. Disponível em:

$<$ http://seer.franca.unesp.br/index.php/historiaecultura/article/view/1113>. Acesso em: 11 set 2014.

Homenagem ao mundo: sobre a função primeira da ornamentação. Revista do

Colóquio de Arte e Pesquisa do PPGA-UFES, v. 3, p. 137-150, 2014. Disponível em: <http://periodicos.ufes.br/colartes/article/view/7712>. Acesso em: 11 set. 2014

PELAYO, Marcelino Menéndez. Historia de los Heterodoxos Españoles, tomo I. Madrid: 1978. Disponível em:

<http://www.ignaciodarnaude.com/textos_diversos/Menendez\%20Pelayo,Heterodoxos\%20Es panyoles.pdf.> Acesso em: 28 out. 2014.

PEREIRA, José Eduardo López. La crónica mozárabe del 754. Zaragoza: Anubar, 1980.

PEREIRA, Maria Cristina C. L. Da queda para o alto: vícios e virtude em uma miniatura românica. In: FOGELMAN, Patricia (Org.). Actas del I Simposio sobre Religiosidad, Cultura y poder. Universidad de Buenos Aires, 22 y 23 de junio de 2006. Buenos Aires: GERE, 2006.

PÉREZ, José Carlos Valle. Entre a continuidade alto-medieval e a renovação gótica: a arquitetura no Caminho de Santiago em Castela e Leão entre 1035 e 1230. In: GUINEA, Juan Carlos Elorza (dir.). Caminhos de Santiago: Arte no período românico em Castela e Leão, Espanha (séc. XI ao XIII) São Paulo: Junta de Castilla y León, Instituto Inclusartiz, 2007, p. $52-72$.

PESAVENTO, Sandra Jatahy. Fronteiras da ficção. Diálogos da história com a literatura. Revista de História das Ideias, Coimbra, v. 21, p. 33-57, 2000.

POLASTRON, Lucien X. Livres en feu. Histoire de la destruction sans fin des bibliothèques. París: Denoël, 2004.

POULIQUEN, Marc Le. Using lattices for reconstructing stemma. Fifth international conference on concept lattices and their applications, Montpellier, 24-26 octobre 2007. Disponível em: 〈http://ceur-ws.org/Vol-331/Le_Pouliquen.pdf>. Acesso em: 15 dez. 2015.

PRÉVOST, Bertrand. Cosmique cosmétique. Pour une cosmologie de la parure. Images Revues, n. 10, p. 02-32, 2012. Disponível em: 〈http://imagesrevues.revues.org/2181〉. Acesso em: 10 nov. 2014

PRADO-VILAR, Francisco. Silentium: El silencio cósmico como imagen en la Edad Media y la Modernidad. Revista de poética medieval, 27, p. 21-43, 2013.

PUHVEL, Jaan. The Origins of Greek Kosmos and Latin Mundus. The American Jounral of Philology, vol. 97, n. 2, p.154-167, Summer, 1976. 
QUENTIN, Henri. Essais de critique textuelle (Ecdotique). Paris: Éditions Auguste Picard, 1926.

REINHOLD, Meyer. History of purple as a Status Symbol in Antiquity. Bruxelas: Collections Latomus, 116, 1970.

RIEGL, Aloïs. Problemas de estilo: fundamentos para una historia de la ornamentación. Versión castellana de Frederico Miguel Saller. Barcelona: Gustavo Gili, 1980.

RISCO, Manuel. España Sagrada. Madri: Biblioteca Pública de Segovia, 1787, tomo XXXVI, pp. CLXXXVIII-CXCII. Disponível em:

<http://bibliotecadigital.jcyl.es/i18n/consulta/registro.cmd?id=4608>. Acesso em: 03 jun. 2014.

RIVERA RECIO, Juan Francisco. El adopcionismo en España, siglo VIII: historia y doctrina. Toledo: Seminario Conciliar de San Ildefonso, 1980.

ROMERO POSE, Eugenio. Ticonio y su comentario al Apocalipsis. Salmanticensis, vol 32, fasc.1, p.35-48, 1985. Disponível em:

<http://summa.upsa.es/pdf.vm?id=0000007252\&page=1\&search=\&lang=es>. Acesso em: 22 out. 2014.

. Ticonio en la historia y literatura cristiana en el Norte de África. In: MARIN, M.; MORESCHINI, C. (ed.), Africa cristiana. Storia, riligione, letteratura. Brescia: Morcelliana, 2002.

ROSSUM, Gerhard Dohrn-van. Les 'horologia' médiévaux et la mise au point de l'horloge à rouages. In: . L'histoire de l'heure: l'horlogerie et l'organisation moderne du temps. Paris: Éditions de la Maison des Sciences de l'homme, 1997, p. 47-130.

RUIZ GARCÍA, Elisa. Manual de codicología. Salamanca: Fundación Germán Sánchez Ruipérez, Madrid: Pirámide, 1988, p. 133. p.137-176.

Arma regis: los libros de Fernando I y doña Sancha. Revista Lemir. n.18, 2014,

SÁNCHEZ BELDA, Luis. Cartulario de Santo Toribio de Liébana. Madri: Arquivo Histórico Nacional, 1948

SÁNCHEZ MARIANA, Manuel. Bibliófilos españoles desde sus orígenes hasta los albores del siglo XX. Madrid: Ollero e Ramos, 1993.

La tradición de los Beatos y el 'Beato de Fernando I y Sancha'. In: WILLIAMS, John et al. Beato de Fernando I y Sancha. Barcelona: M. Moleiro, 2006, p.31-58.

SANDERS, H. A. Beati in Apocalypsin libri duodecim. Roma: Papers and monographs of American Academy in Rome, II, 1930.

SANTOS, Aline Benvegnú dos. A ornamentalidade dos capitéis do claustro de Sant Benet de Bages: as funções do decor na arte românica. 2014. 243 p. Dissertação (Mestrado em História Social) - Programa de Pós-Graduação em História Social, Universidade de São Paulo, São Paulo, 2014. 
SANTOS, Maria José Azevedo. Ler e compreender a escrita na Idade Média. Lisboa, Edições Colibri e Faculdade de Letras da Universidade de Coimbra, 2000.

SANTOS, Selene Candian. Arte retórica em Ordinatio, De consecratione e De administratione de Suger de Saint-Denis. 2014. 2 volumes. (Mestrado em História Social) Programa de Pós-Graduação em História Social, Universidade de São Paulo, São Paulo, 2014.

SARTRE, Jean-Paul. A imaginação. Porto Alegre, RS: L\&PM, 2011.

SCHAPIRO, Meyer. The Beatus Apocalypse of Gerona: late antique, early Christian and medieval art. New York: George Braziller, 1979.

Estudios sobre el românico. Madrid: Alianza, 1984.

Les mots et les images: sémiotique du langage visuel. Paris: Macula, 2000.

SCHMITT, Jean-Claude. La culture de l'imago. Annales. Histoire, Sciences sociales, 51 année, n.1, 1996, p. 3-36. Disponível em: <www.persee.fr/doc/ahess_03952649_1996_num_51_1_410832>. Acesso em: 23 nov. 2015.

De l'espace aux lieux: les images médiévales. Actes des congrès de la Société des historiens médiévistes de l'enseignement supérieur public. Construction de l'espace au Moyen Age:pratiques et représentations. 37e congrès, Mulhouse, 2006, p. 317-346.

EDUSC, 2007.

O corpo das imagens: ensaios sobre a cultura visual na Idade Média. Bauru, SP:

SEPÚLVEDA GONZÁLEZ, María de los Ángeles. Los anagramas y el programa iconográfico de Quintanilla de las Viñas: una hipótesis de interpretación. La España Medieval. Madri, Editorial de la Universidad Complutense, Tomo V, v. 9, p. 1217-1248, 1986. Disponível em:

<http://revistas.ucm.es/index.php/ELEM/article/view/ELEM8686221217A/24339>. Acesso em: 14 jan. 2016.

La iconografía del beato de Fernando I (Aproximación al estudio iconográfico de los beatos). Tomo II. Madri: Universidad Complutense de Madrid, 1987.

SEVILLA-QUIÑONES, Margarita Torres. Espacios y sociedad en león durante los siglos XI y XI. In: GUINEA, Miguel Ángel G.; GONZÁLEZ, José María Pérez. (ed.) Enciclopedia del Románico en Castilla y León. Santander: Fundación Santa Maria la Real. Centro de Estudios del Románico. Vol 3.

SHAILOR, Barbara A. The Medieval Book. Toronto: University of Toronto Press, 1991.

SILVEIRA, Aline Dias da. Europeização e/ou Africanização da Espanha Medieval:

Diversidade e unidade cultural européia em debate. Revista de História, v. 28, n.2, p.645$658,2009$.

SULLIVAN, Louis Form and function. In: Kindergarten Chats and Other

Writings. Nova York: Wittenborn Art Books, 1968. 
TURNER, Eric G. The Terms Recto and Verso. The Anatomy of the Papyrus Roll. Actes XVe congrès international de papyrologie, première partie, L'antiquité classique, Tome 49, 1980, Bruxelles: Fondation Egyptologique Reine Elisabeth, p. 471-472.

VIEIRA, Fernando G. P. A ficção como limite: reflexões sobre o diálogo entre história e literatura. Fronteiras: Revista Catarinense de História, Florianópolis, n.17, p.13-31, 2009.

VIVES, José (Ed.). Concilios Visigóticos e Hispano-romanos. Madrid-Barcelona: Consejo superior de investigaciones científicas. Instituto Enrique Flóres, 1963.

WERCKMEISTER, Otto Karl. The first Romanesque Beatus manuscripts and the Liturgy of death, Actas del Simposio para el estudio de los códices del «Comentario al Apocalipsis» de Beato de Liébana. Madrid: Joyas Bibliográficas, 1978, p. 165 et seq

WILLIAMS, John. Las miniaturas del Comentario en Los Beatos. Madri: Biblioteca Nacional, 1986.

The illustrated Beatus: a corpus of the illustrations of the Commentary on the Apocalypse. London: Harvey Miller, 1994-2003. 5v.

The Beatus Text. In: The illustrated Beatus: a corpus of the illustrations of the Commentary on the Apocalypse. London: Harvey Miller, 1994-2003, v. 1, p. 19-30. et al. Beato de Fernando I y Sancha. Barcelona: M. Moleiro, 2006.

WIRTH, Jean. L'image médiévale: Naissance et développements (VIe-XVe siècle). Paris: Méridiens Klincksieck, 1989.

L'image à l'époque romane. Paris: Cerf, 1999.

YARZA LUACES, Joaquín. Los seres fantásticos en la miniatura castellano-leonesa de los siglos XI y XX. In: editorial del hombre, 1987, p.156-181. Formas artísticas de lo imaginario. Barcelona: Anthropos La ilustración del Beato de Fernando I y Sancha. In: WILLIAMS, John et al. Beato de Fernando I y Sancha. Barcelona: M. Moleiro, 2006, p. 59-90.

Las miniaturas. In: WILLIAMS, John et al. Beato de Fernando I y Sancha. Barcelona: M. Moleiro, 2006, p. 92-300.

La miniatura Medieval em la Península Ibérica. Murcia: Nausicaä, 2007. 


\begin{abstract}
ANEXOS
ANEXO A - Sistema de Blocos

"Sistema é uma apresentação de rede de conexões" (p. 122). Criamos esta ferramenta para podermos visualizar possíveis interações entre os fólios ocupados por imagem, apenas, ou por texto e imagem. Por lidarmos com um conjunto grande de miniaturas dentro da complexidade de definição do que é a imagem, encontramos dificuldade mesmo para numerálas. Dissemos que o Beatus de Facundus possui 98 miniaturas, mas como lidar com os ff. 201 e $202,{ }^{364}$ referentes às tábuas do Anticristo e a seus nomes, respectivamente? São imagens, não são? Um sistema não fornece uma resposta exata, porque não pertence a ele as respostas, somente as dúvidas, os indícios de que algo precisa ser pensado e desenvolvido.

Para montar esse sistema de blocos, criamos grupos a partir da ocupação espacial do fólio e a convivência entre texto e imagem. As possibilidades de relações entre os grupos podem formar novos blocos, a depender da pergunta que impomos. Ao todo, distinguimos sete grupos, que se observados atentamente, podem somar outro número.
\end{abstract}

Grupo 1: imagens que ocupam um fólio inteiro, sem a presença de texto (representadas na cor azul clara). ${ }^{365}$ Esse grupo ainda pode ser desmembrado em imagens com ou sem tituli (inscrições); com ou sem borda (neste caso, incluímos as imagens do Comentário a Daniel e a de f. $202^{366}$ ); no caso de existir borda, ela será retangular (maioria) ou com um formato diferencial da maioria (ovais, como f. 145; ovais com elementos figurativos externos, f. 116v; em forma de arco no ciclo dos evangelistas); as imagens do Grupo 1 ainda podem estar

\footnotetext{
${ }^{364}$ Disponível em: <http://bdh-rd.bne.es/viewer.vm?pid=d-1806167>. Acesso em: 25 nov. 2015.

${ }^{365}$ Vale ressaltar que na representação do Sistema de blocos aqui exposta, a cor não guarda muita fidelidade com o real, devido às necessidades de edição técnica da imagem para que ela deixasse momentaneamente seu corpo de cerca de $4 \mathrm{~m}$, para ocupar pequenos espaços digitais. Para que a marcação cromática do Sistema fosse transposta para este espaço, seria necessário abdicar do esquema original e propor outras configurações, que não aquelas utilizadas desde o início para compor o trabalho. Falamos aqui de processo e não de resultados.

366 A imagem de f. 202 evidencia o quanto um esquema pode ser contraditório, se ele não pauta pela flexibilidade do sistema. A imagem terá uma borda quando comparada as imagem do ciclo dos evangelistas, pela aproximação formal dos arcos. Mas ela não terá uma borda se pensarmos no que a separa das outras imagens com arcos - a ausência de bandas de cor ou outro elemento que distingue porção interior e exterior. O mesmo vale para of. $281 \mathrm{v}$.
} 
destacadas do fólio pela presença de borda e bandas de cor ou inscritas diretamente sobre a superfície de inscrição (imagens do Comentário a Daniel).
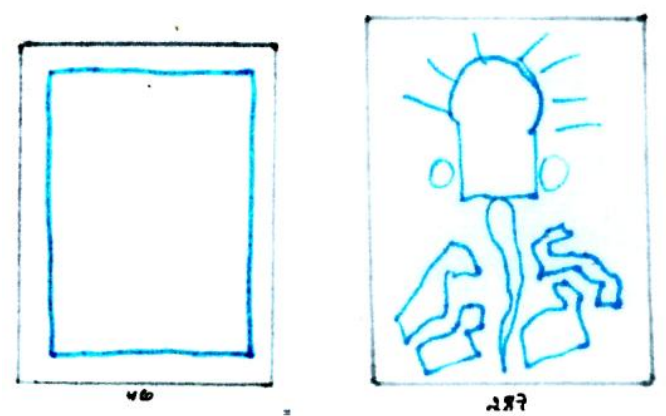

Figura 1. Grupo 1, ff. 46, 287.

Grupo 2: Imagens diferenciadas pela ocupação de dois fólios, com ou sem a presença de texto (representadas na cor azul escura). A presença do texto é facilmente identificada no sistema pela representação das linhas de escrita em igual número a que aparecem nos fólios (os números de linhas são colocados na margem externa, de cor cinza, que representa o fólio do manuscrito).
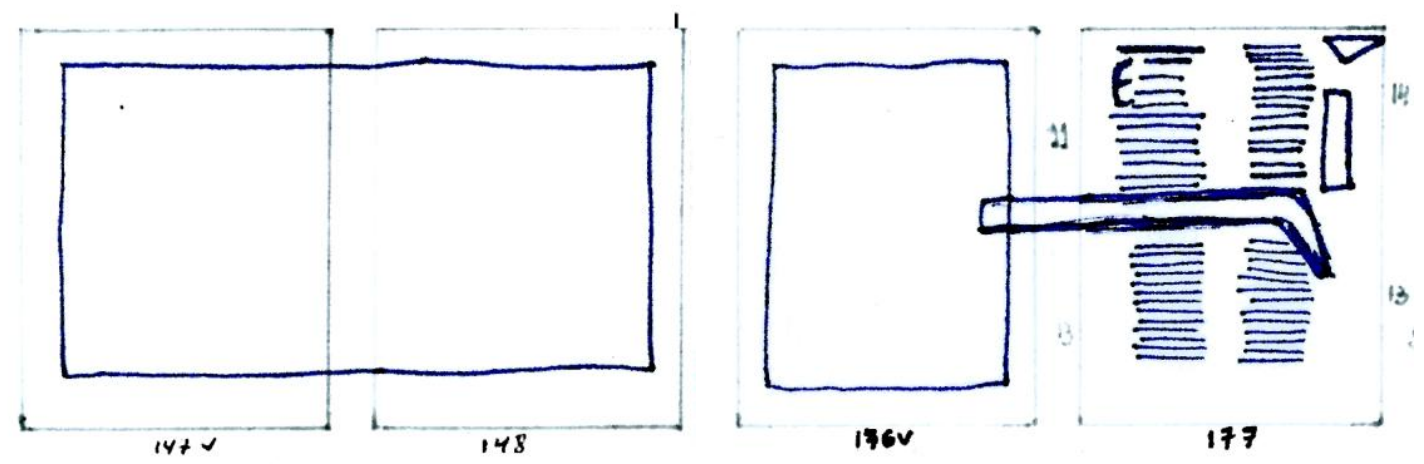

Figura 2. Grupo 2, ff. 147v-148, 176v-177

Grupo 3: Fólios ocupados por texto e imagem, em que a imagem ocupa a parte superior e o texto a parte inferior do fólio (representados na cor vermelho escuro). 


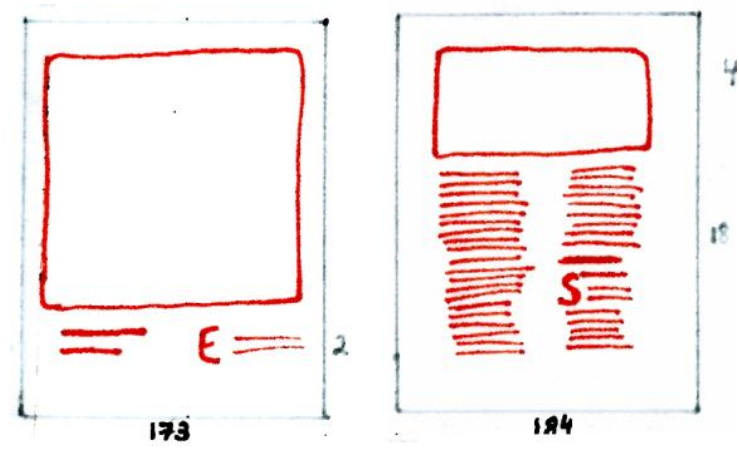

Figura 3. Grupo 3, ff. 173, 184.

Grupo 4: Fólios ocupados por texto e imagem, em que a imagem ocupa a parte inferior e o texto a parte superior do fólio (representados pela sobreposição de linhas marrom sobre linhas laranja).

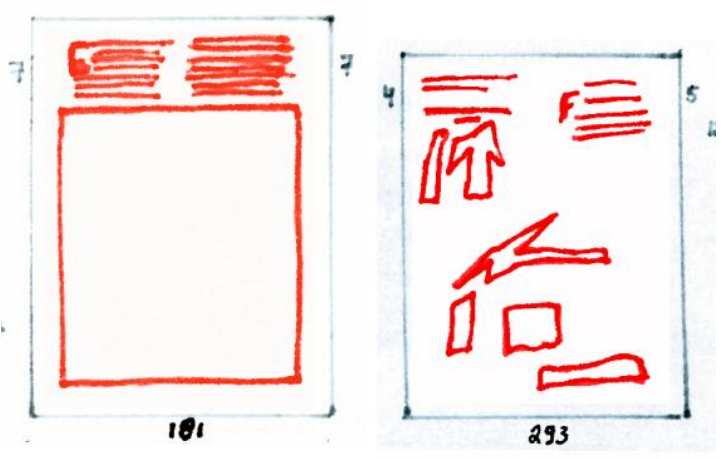

Figura 4. Grupo 4, ff. 181, 293.

Grupo 5. Fólios ocupados por texto e imagem, em que a imagem coloca-se intercalada ao texto na ocupação de apenas uma coluna (representados na cor violeta).

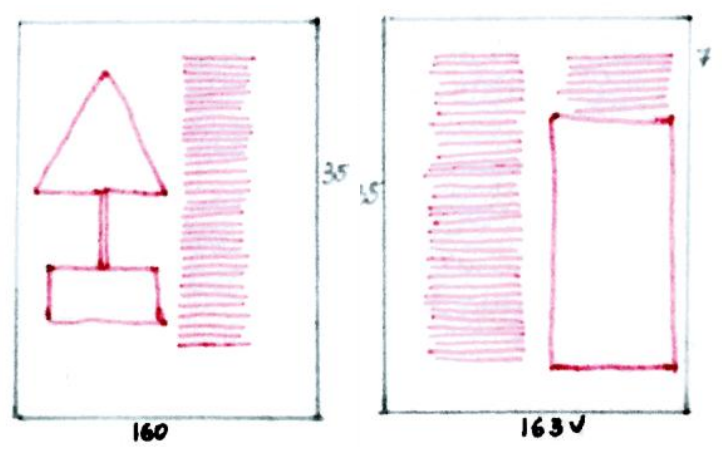

Figura 5. Grupo 5, ff. 160, 163. 
Grupo 6. Fólios ocupados por texto e imagem, em que a imagem coloca-se intercalada ao texto na ocupação das duas colunas (representados na cor verde escura).

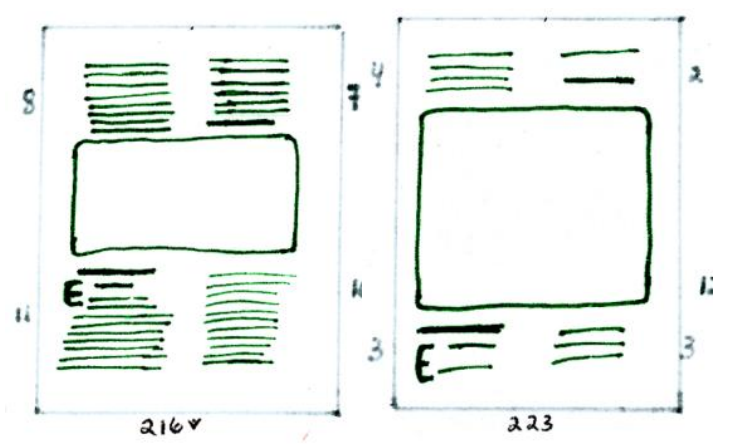

Figura 6. Grupo 6, ff. 216v, 223

Grupo 7. Reúne dois fólios específicos, ff. 70v e 216, que se distanciam dos demais quando observamos a relação com a leitura do texto (representados na cor verde clara). A leitura do texto, no Beatus de Facundus, começa na parte superior da primeira coluna e, após o fim da primeira coluna, segue para a parte superior da segunda coluna. Essa sequência se mantém quando a imagem não fragmenta o texto (Grupo 3 e 4) ou quando o fragmenta em apenas uma das colunas e a leitura segue normalmente (Grupo 5). Contudo, quando o texto é interrompido por uma imagem nas duas colunas, em geral, a leitura não segue a primeira e depois a segunda coluna, mas divide o fólio em quatro colunas, em que são lidas as da parte superior e depois as colunas da parte inferior do fólio, como no f. 216v (Figura 7). No f. 70v, a imagem interrompe o corpo do texto, mas não a leitura, que segue da primeira para a segunda coluna. No f. 216, aparecem duas imagens que cercam o texto no centro do fólio, dinâmica que não acontece em nenhuma outra imagem.
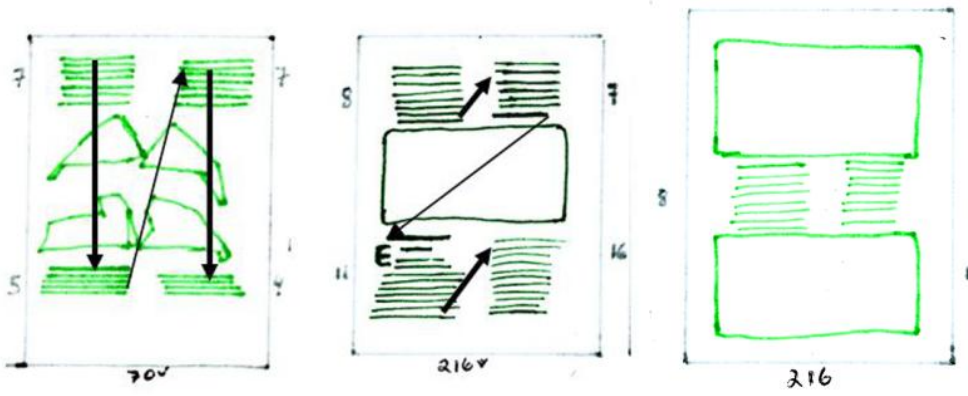

Figura 7. Grupo 7, ff. 70v, 216v, 216. 
A reunião dos grupos forma uma tira de cerca de quatro metros que permite uma representação dos fólios desmembrados do corpo do livro. O sistema de blocos torna-se uma ferramenta de visualização.

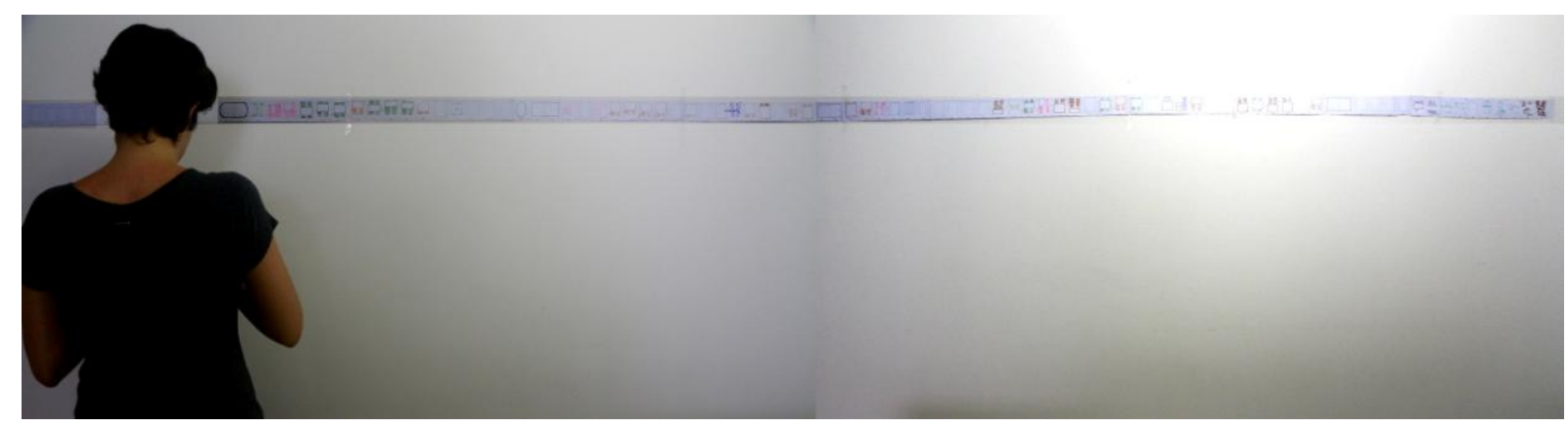

Figura 8. Sistema de blocos, vista panorâmica.

A seguir, transferimos a tira para o formato da página deste livro, com o intuito de um melhor entendimento, para o leitor, da construção dessa ferramenta, mas devemos advertir que a fragmentação da tira implica o desmantelamento de parte de sua funcionalidade. ${ }^{367}$

\footnotetext{
${ }^{367} \mathrm{Na}$ tentativa de permitir a sua funcionalidade, disponibilizamos uma versão do Sistema de blocos, que pode ser impressa em tira. Disponível em: <http://notamanuscrita.com/2016/01/09/beatusdefacundus/>. E também compreendemos que às vezes é necessário se reportar ao autor para outras versões do material ou de novos materiais. Para tanto, pode-se recorrer ao mesmo site ou ao contato por e-mail <fabianapedroni@yahoo.com.br>.
} 

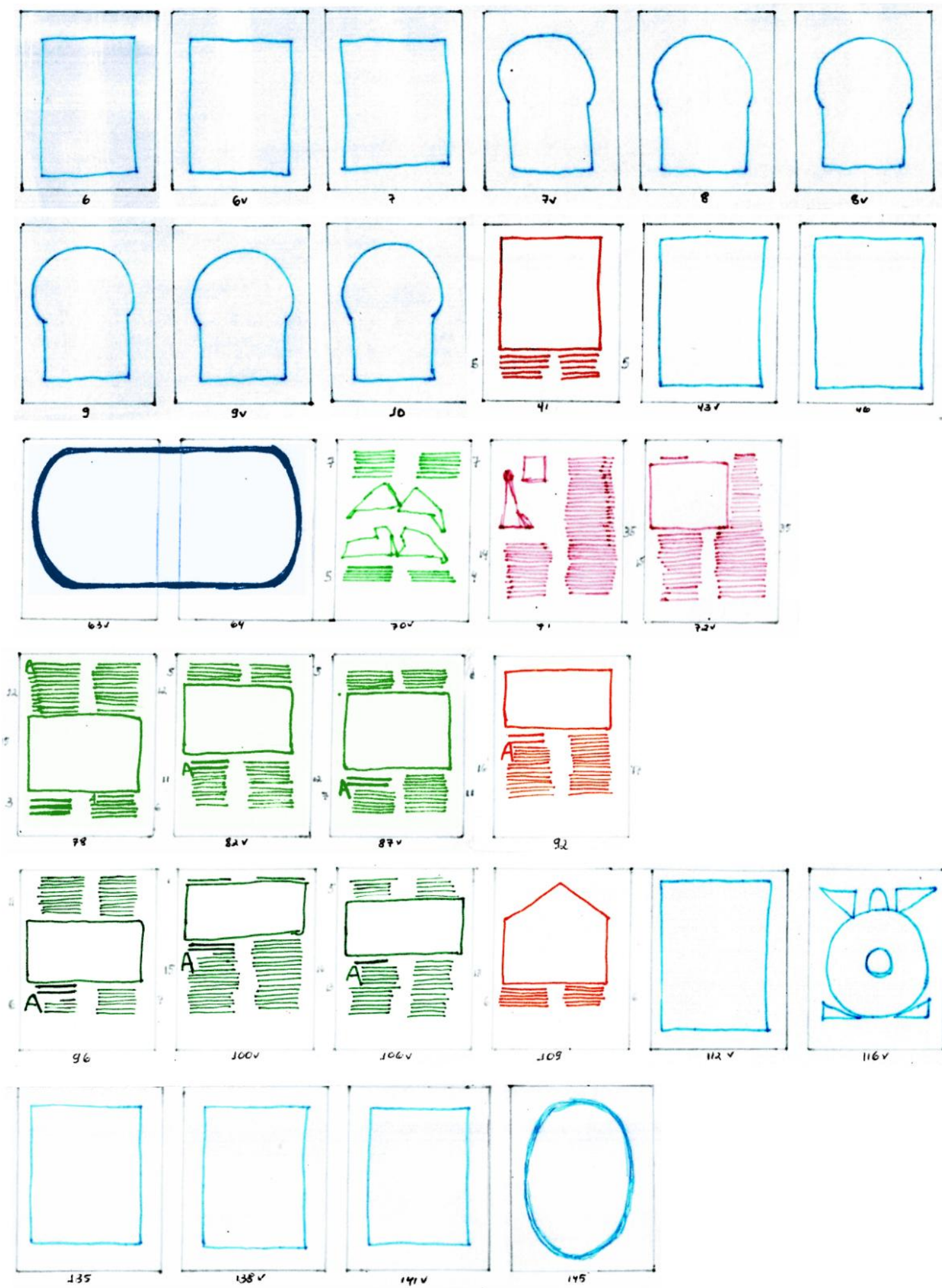

soov
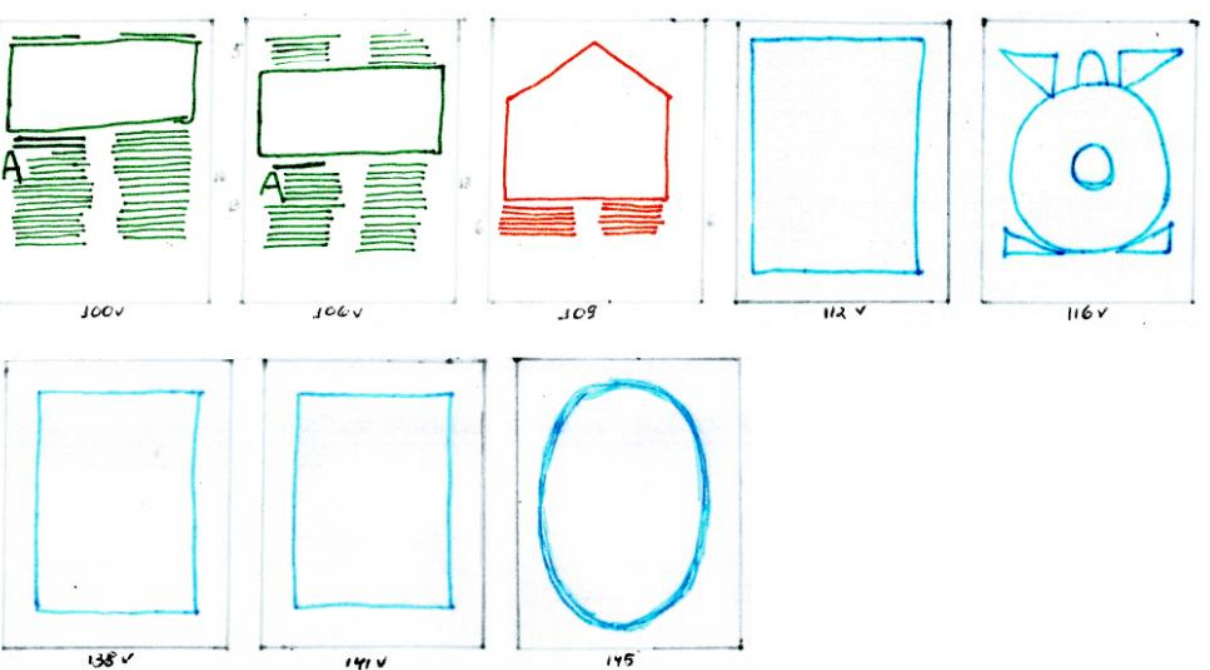

109

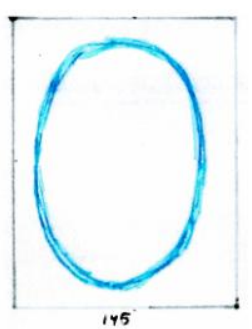



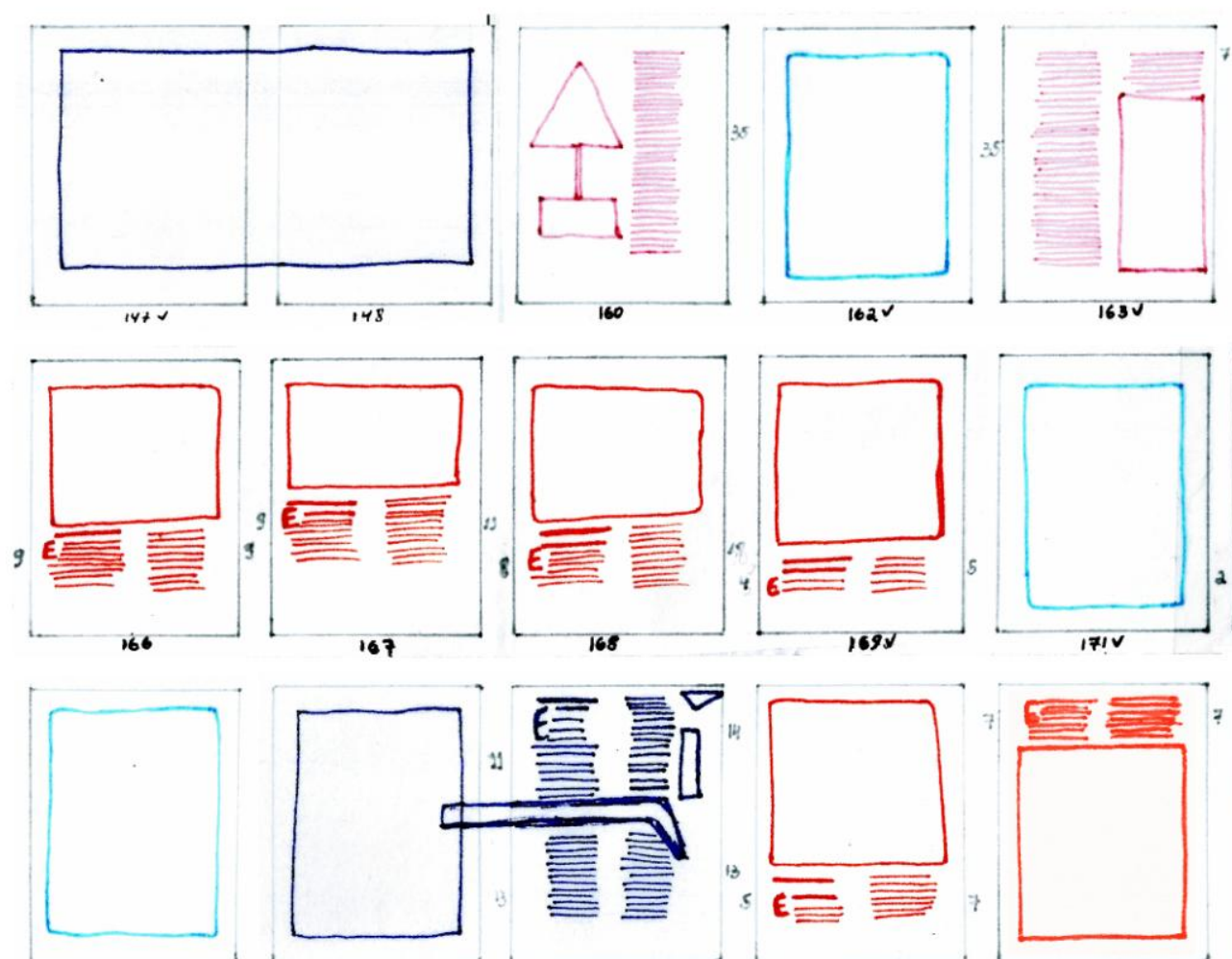

174
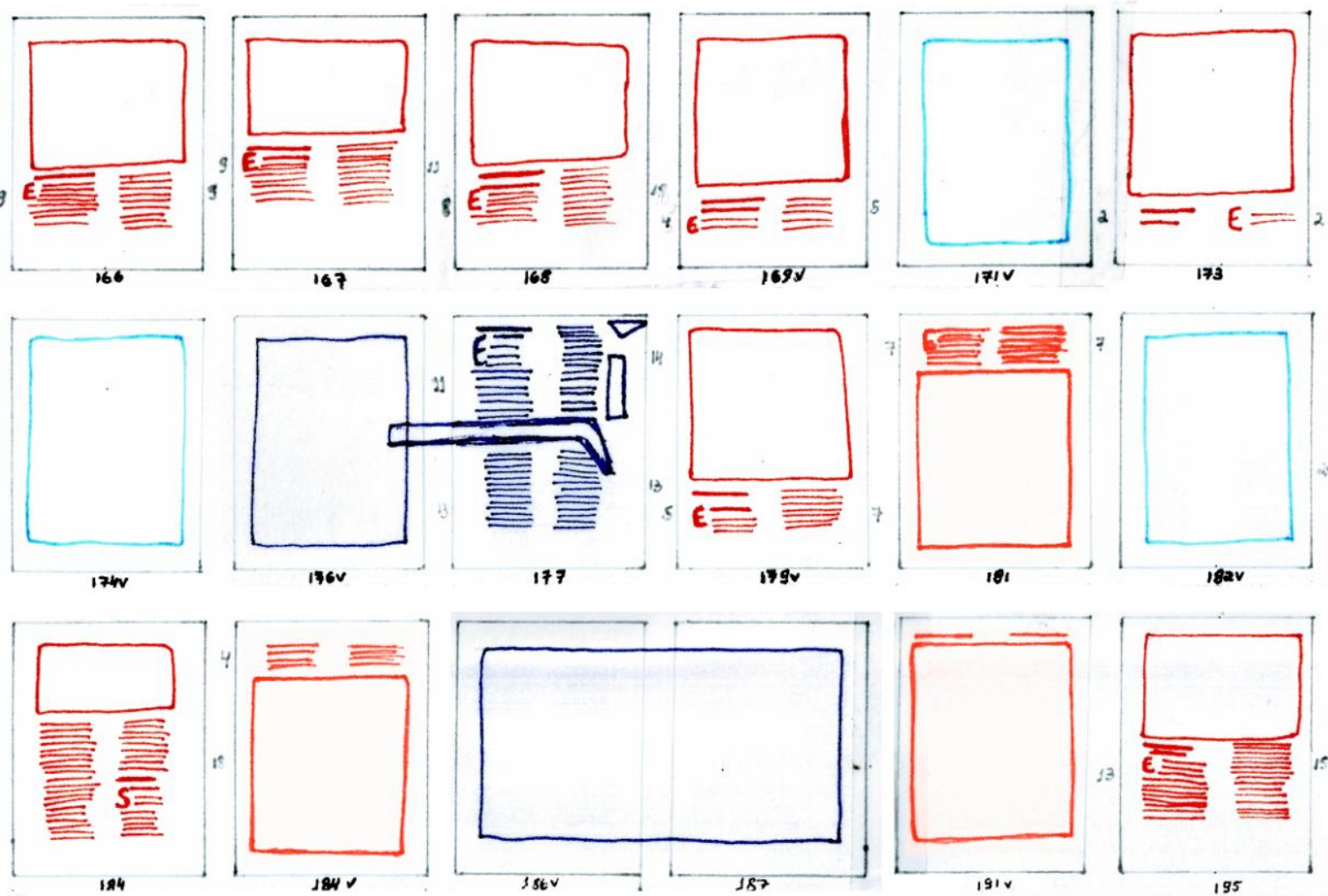

$179 v$
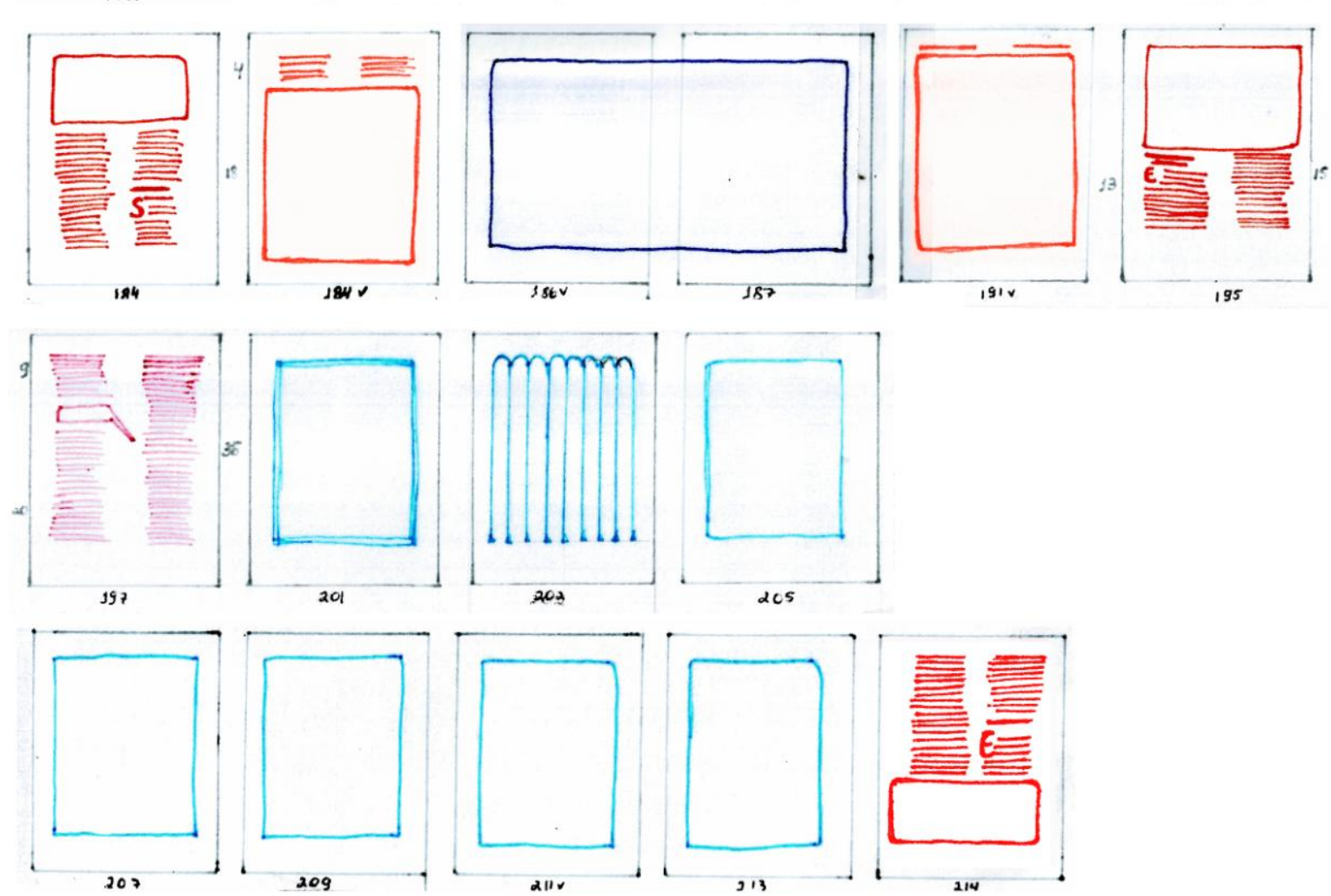


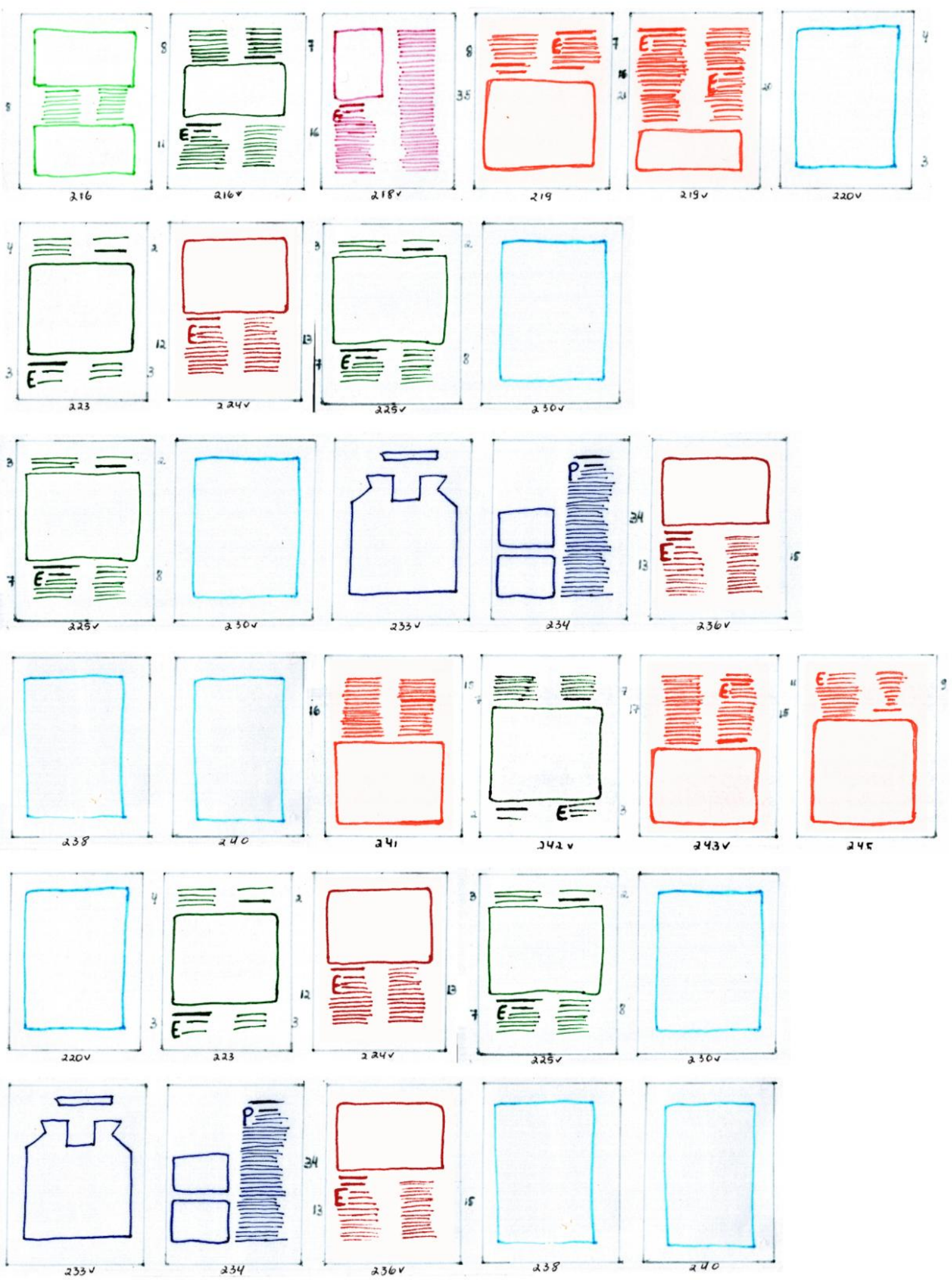



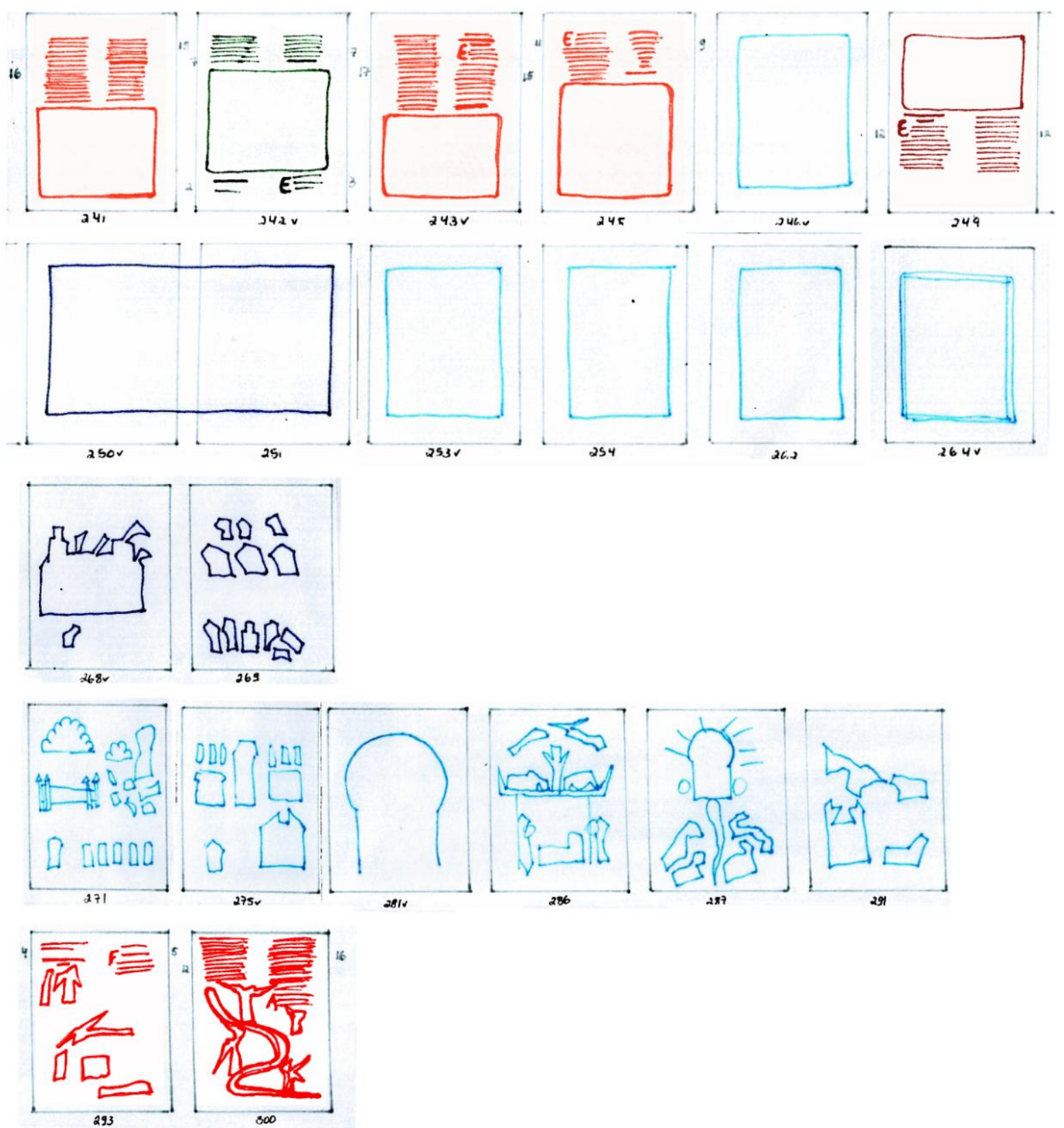

Figura 9. Sistema de blocos, montagem em 4 pranchas. 


\section{ANEXO B - Processos de Escrita}

Aqui apresentamos alguns indícios do trabalho de escrita. São mostras do que discorremos na dissertação sobre encadeamento e visualização de ideias. Nas duas primeiras figuras, temos o desenvolvimento do capítulo 2 "As camadas da imagem ou Por que livros precisam de sobrenome". Lidar com a materialidade do Beatus de Facundus exigiu-nos dar certo corpo aos argumentos. Na Figura 12, partirmos dos conceitos usados no capítulo 3, "Como abraçar uma máquina: o ornamento como engrenagem da máquina", para compor a maior parte da estrutura dissertativa, sobre o ornamento e suas funcionalidades.

Em seguida, acrescentamos dois pequenos textos que foram essenciais para compor os capítulo 3 e 5. São estruturações que dialogam e dão origem ao trabalho de modo literário. Textos que não são pensados para "acrescentar discurso", mas para recapitular e relacionar questões que são ditas de modo muitas vezes distantes de nossa vivência em tempos "contemporâneos". Esses textos necessitam de uma leitura própria à literatura, aquela que não soma as parte e dá resultados, mas que valoriza as lacunas e a imaginação, necessárias para uma inventio produtiva.
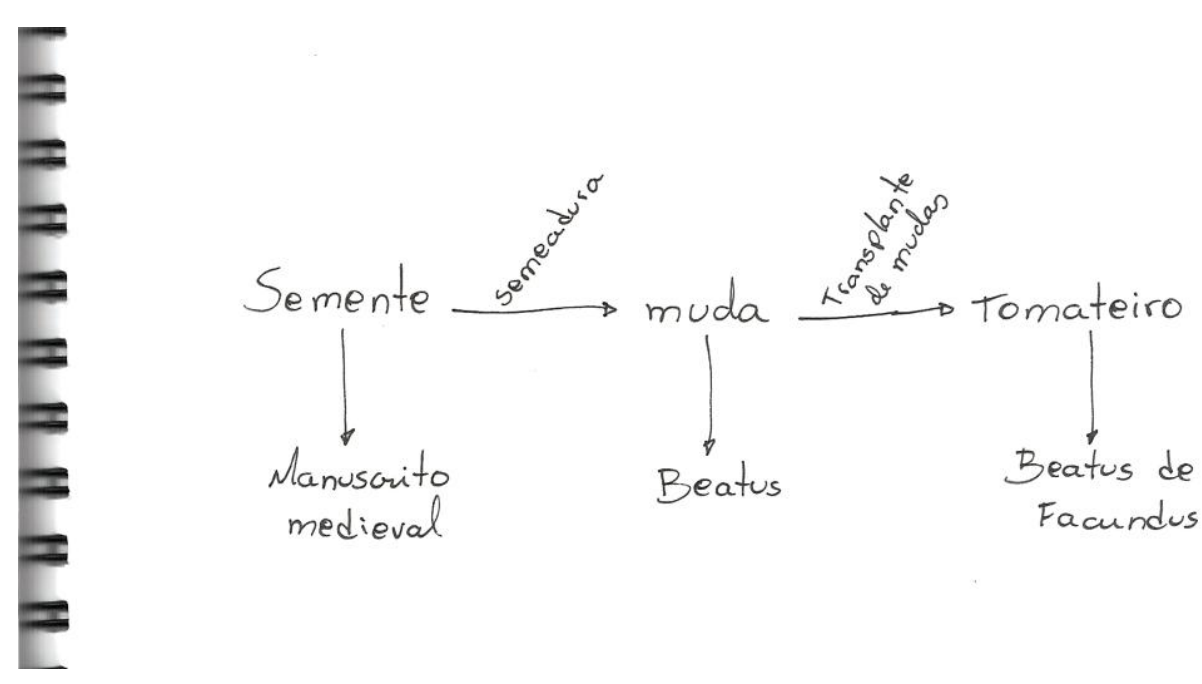

Figura 10. Capítulo 2, semeadura. 


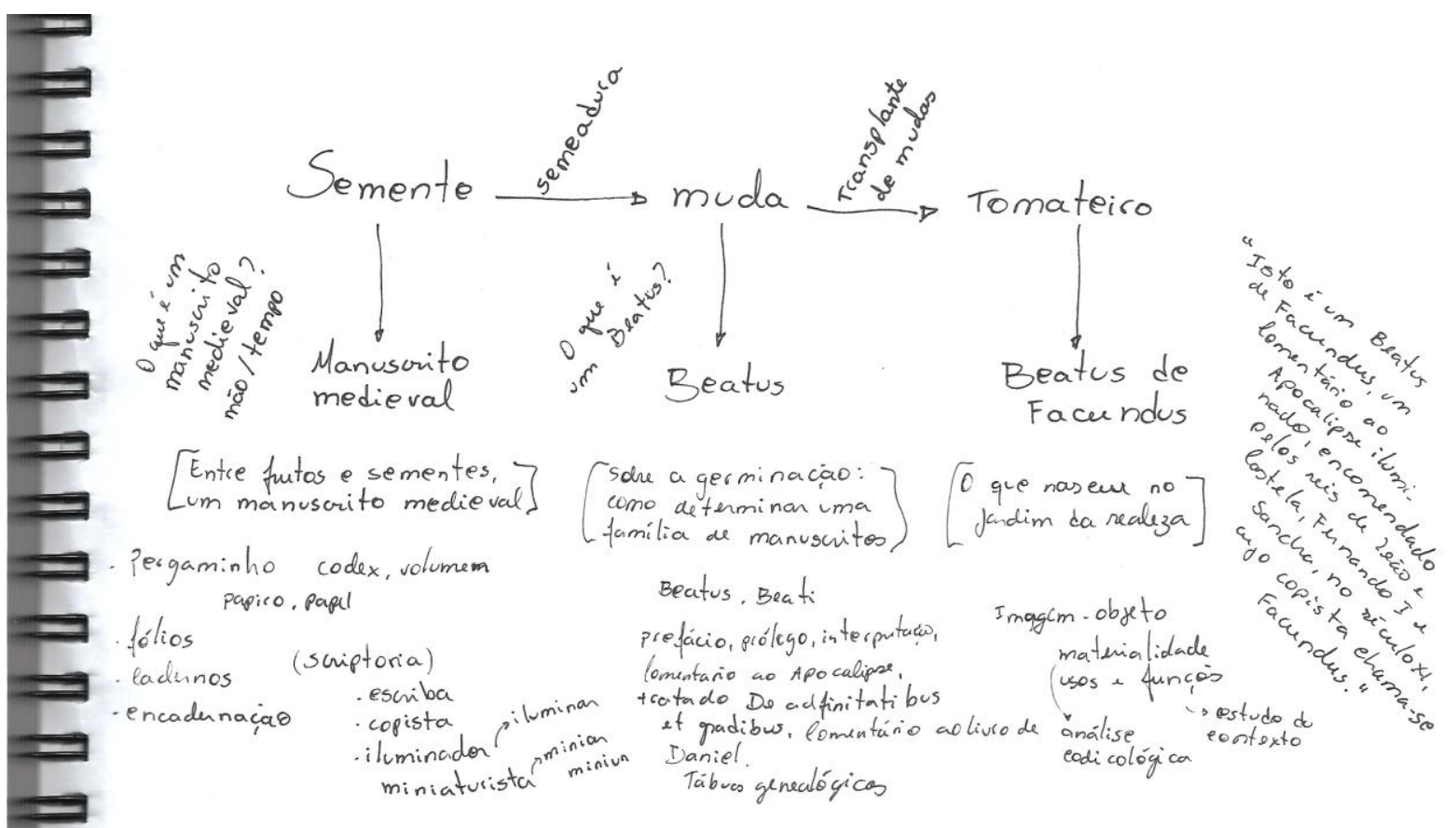

Figura 10. Capítulo 2, brotamento.
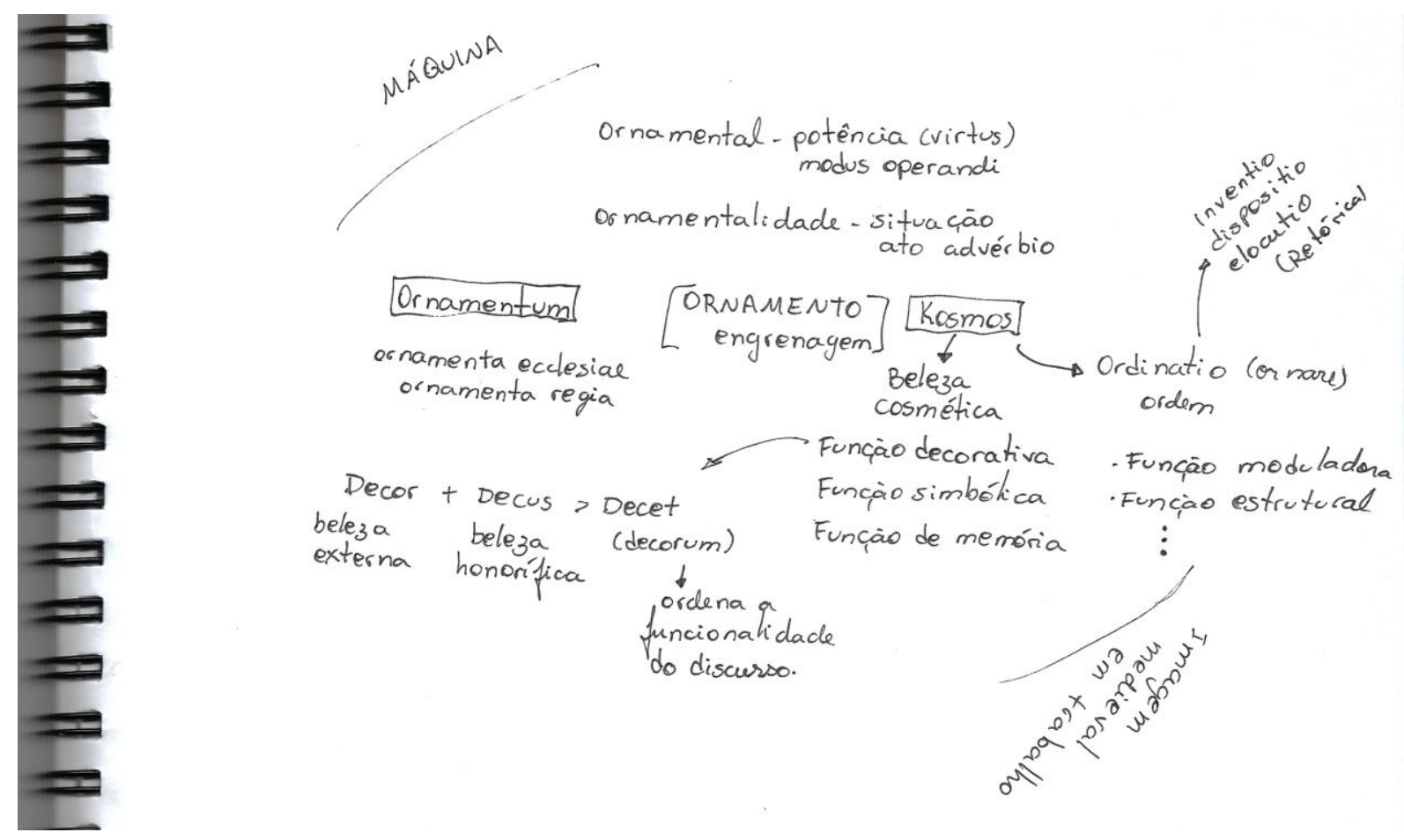

Figura 11. Ornamento como engrenagem 
Como abraçar sem se perder no olhar:

No reino Pingouin, para falar ou ser ouvido, antes era necessário ser abraçado. Um gesto de reconhecimento entre as partes, por vezes inconsciente, do início de um discurso. Toda audiência precedia da demonstração de que falar e ouvir eram também gestos corporais de entendimento. Conta a lenda, que durante o reinado de Pingu, a normativa, que com o tempo deixou o âmbito da norma para o hábito, foi suspensa. O rei Pingu não sabia abraçar. A princípio, poderia ser uma fobia, mesmo que não houvesse uma fobia específica ao abraço (ou seria um medo generalizado, pois alguns poucos antecessores foram feridos durante o ato, ou ainda, a simples falta de gosto).

A despeito da revogação de tão profunda tradição, Pingu desejava abraçar. A seu conselheiro, um dos poucos amigos dos quais o rei não guardava ressalvas, ele descrevia $\mathrm{O}$ abraço: "Eu me aproximo, o outro se aproxima e estende os braços. Quando penso em estender os meus, não consigo, porque meus olhos não deixam. Eu vejo um corpo inclinado, a pele esticada, os músculos tensionados, os ossos dobrados, as junções, o ranger da matéria, o sangue pulsado, as hemácias deslocadas, o oxigênio que corre, outras moléculas por mim inomináveis, presas em gordura, os prótons, os elétrons e... apavoro-me, porque tudo isso me encosta antes que eu possa ver a imagem". Depois de muitas tentativas de abraços em filhotes de cães e guanacos (exercícios de meia vida para tentar integrar-se ao seu povo e sentir-se em casa), seu conselheiro disse-lhe: "Apenas feche os olhos e veja o abraço-ato".

$$
* * *
$$

Sobre as especificidades da matéria:

Tomei uma imagem medieval, feita em pergaminho, deslumbrei-me com a textura da página e resolvi emoldurá-la. Comprei com seu José a moldura mais bonita da loja, aquela toda trançada que mais parece a grade da janela do meu avô. Fiz dela um quadro e preguei na parede da sala. Não entendi muito bem quando minha prima disse que isso parecia uma aberração, mas eu não queria comprar mais um busto de gesso ou alugar uma performance por um dia. 


\section{ANEXO C - Relação de Beati e stemma codicum}

\begin{tabular}{|c|c|c|c|c|c|c|c|}
\hline \multirow{2}{*}{ Datación } & \multirow{2}{*}{ Lugar } & \multirow{2}{*}{ Procedencia } & \multirow{2}{*}{$\begin{array}{l}\text { Cód./ } \\
\text { frag. }\end{array}$} & \multirow{2}{*}{$\begin{array}{c}\text { minia- } \\
\text { turas } \\
\text { con } / \sin \\
\end{array}$} & \multicolumn{3}{|c|}{ Siglas } \\
\hline & & & & & Sanders & Neuss & Mundó: \\
\hline IX & Mon. Silos & Cirueña (Rioja) & frag. & $\min$. & - & $\mathrm{F}$ & 30 \\
\hline $\begin{array}{l}\mathrm{X}\left(1 .^{2}\right. \\
\text { mitad })\end{array}$ & Bibl. Nac. Madrid & S. Millán & cód. & $\min$. & $\mathrm{N}$ & $A^{\prime}$ & 13 \\
\hline 952 & $\begin{array}{l}\text { Morgan Libr. Nueva } \\
\text { York }\end{array}$ & S. Miguel Escalada & cód. & $\min$. & $\mathrm{Y}$ & M & 21 \\
\hline $968-970$ & $\begin{array}{l}\text { Arch. Hist. Nac. Ma- } \\
\text { drid }\end{array}$ & Monas. de Tábara & cód. & $\min$. & A & $\mathrm{T}$ & 12 \\
\hline 970 & Un. Valladolid & Monas. Valcavado & cód. & $\min$. & $\mathrm{V}$ & $\mathrm{V}$ & 32 \\
\hline 975 & Catedr. Gerona & Cat. Gerona & cód. & $\min$. & G & G & 6 \\
\hline $\mathrm{X}$ & Cat. Seo Urgel & Cat. Seo de Urgel & cód. & $\min$ & $\mathrm{U}$ & $\mathrm{U}$ & 28 \\
\hline $\mathrm{X}$ & Bibl. Nac. Madrid & - & frag. & - & 一 & $\mathrm{Fi}$ & 15 \\
\hline $\mathrm{X}$ & S. Pedro Dueñas & Monas. Dueñas & frag. & - & - & - & 27 \\
\hline $\mathrm{X}$ & Monas. Silos & Nájera & frag. & $\div$ & $\bar{\Gamma}$ & $\mathrm{Fc}$ & 29 \\
\hline $\mathrm{X}-\mathrm{XI}$ & Escorial & San Millán & cód. & $\min$. & $\mathrm{E}$ & $\mathrm{E}$ & 4 \\
\hline XI (inic.) & Acad. Hist. Madrid & San Millán & cód. & $\min$. & $\mathrm{H}$ & $\mathrm{A}^{2}$ & 11 \\
\hline 1047 & Bibl. Nac. Madrid & San Isidoro de León & cód. & $\min$. & $\mathrm{M}$ & $\mathrm{J}$ & 14 \\
\hline 1075 & Bibl. Nat. Paris & Monas. Saint-Sever & cód. & $\min$. & $\mathrm{P}$ & $\mathrm{S}$ & 22 \\
\hline 1086 & Cat. Burgo Osma & Cat. Burgo de Osma & cód. & $\min$. & $\mathrm{O}$ & $\mathrm{O}$ & 3 \\
\hline $\mathrm{XI}$ & Mon. Montserrat & Monas. Sahagún & frag. & - & - & - & 19 \\
\hline XI & Chanc. Valladolid & Monas. Sahagún & frag. & - & - & - & - \\
\hline 1100 & Bibl. Naz. Turín & Gerona & cód. & $\min$. & $\mathrm{T}$ & Tu & 31 \\
\hline 1109 & British Libr. Londres & Monas. de Silos & cód. & $\min$. & $\mathrm{S}$ & $\mathrm{D}$ & 10 \\
\hline XII (inic.) & Staatsbibl. Berlin & Italia del Sur & cód. & $\min$. & $\mathrm{F}$ & B & 2 \\
\hline XII (inic.) & $\begin{array}{l}\text { Arch. Aragón Barce- } \\
\text { lona }\end{array}$ & $\begin{array}{l}\text { Cartuja de Montale- } \\
\text { gre }\end{array}$ & frag. & 一 & - & - & 1 \\
\hline XII (inic.) & Acad. Lincei Roma & Aragón & cód. & $\min$. & - & C & 25 \\
\hline XII & $\begin{array}{l}\text { Rylands. Libr. Man- } \\
\text { chester }\end{array}$ & Burgos o León & cód. & $\min$. & $\mathrm{R}$ & $\mathrm{R}$ & 17 \\
\hline XII & Univ. Salamanca & Monas. Poblet & cód. & - & I & $\mathrm{Pp}$ & 26 \\
\hline XII & Arch. Prov. León & León & frag. & $\min$. & - & $\div$ & 7 \\
\hline 1189 & $\begin{array}{l}\text { Arch. T. Tombo Lis- } \\
\text { boa }\end{array}$ & $\begin{array}{l}\text { Monas. San Mamed, } \\
\text { Lorvao }\end{array}$ & cód. & $\min$ & $\mathrm{L}$ & $\mathrm{L}$ & 8 \\
\hline XII (fin.) & Bibl. Nat. Paris & Navarra & cód. & $\min$. & Q & $\mathrm{N}$ & 23 \\
\hline XIII (inic.) & Bibl. Nat. Paris & $\begin{array}{l}\text { Mon. S. Andrés } \\
\text { Arroyo }\end{array}$ & cód. & $\min$. & $\bar{C}$ & $\mathrm{Ar}$ & 24 \\
\hline XII-XIII & $\begin{array}{l}\text { Mus. Arq. Nac. Ma- } \\
\text { drid }\end{array}$ & $\begin{array}{l}\text { Mon. S. Pedro Car- } \\
\text { deña }\end{array}$ & cód. & $\min$. & $\mathrm{D}$ & Pc & 16 \\
\hline 1220 & $\begin{array}{l}\text { Morgan Libr. Nueva } \\
\text { York }\end{array}$ & $\begin{array}{l}\text { Monas. de Las Huel- } \\
\text { gas }\end{array}$ & cód. & $\min$. & B & $\mathrm{H}$ & 20 \\
\hline XIII & Bibl. Nac. Lisboa & Monas. de Alcobaça & cód. & $\div$ & - & - & 9 \\
\hline XIII & Arch. Nac. México & $\begin{array}{l}\text { Castilla (Med. Riose- } \\
\text { co) }\end{array}$ & frag. & $\min$. & - & - & 18 \\
\hline 1552 & Bibl. Vatic. Roma & $\begin{array}{l}\text { Copia del de Plasen- } \\
\text { cia }\end{array}$ & cód. & - & - & Vt & 33 \\
\hline $\mathrm{XVI}$ & Bibl. Escorial & Marqués de Vélez & cód. & - & - & Ex & 5 \\
\hline
\end{tabular}

Figura 12. Relação dos Beati.

Fonte: González Echegaray, 2004. ${ }^{368}$

${ }^{368}$ CAMPO HERNÁNDEZ, Alberto del; FREEMAN, Leslie G.; GONZÁLEZ ECHEGARAY, Joaquín (ed.). Beato de Liébana. Obras completas y complementarias. v. 1. Edição bilíngue do latim ao castelhano. Madrid: Biblioteca de Autores Cristianos, 2004, p. XXXII. 


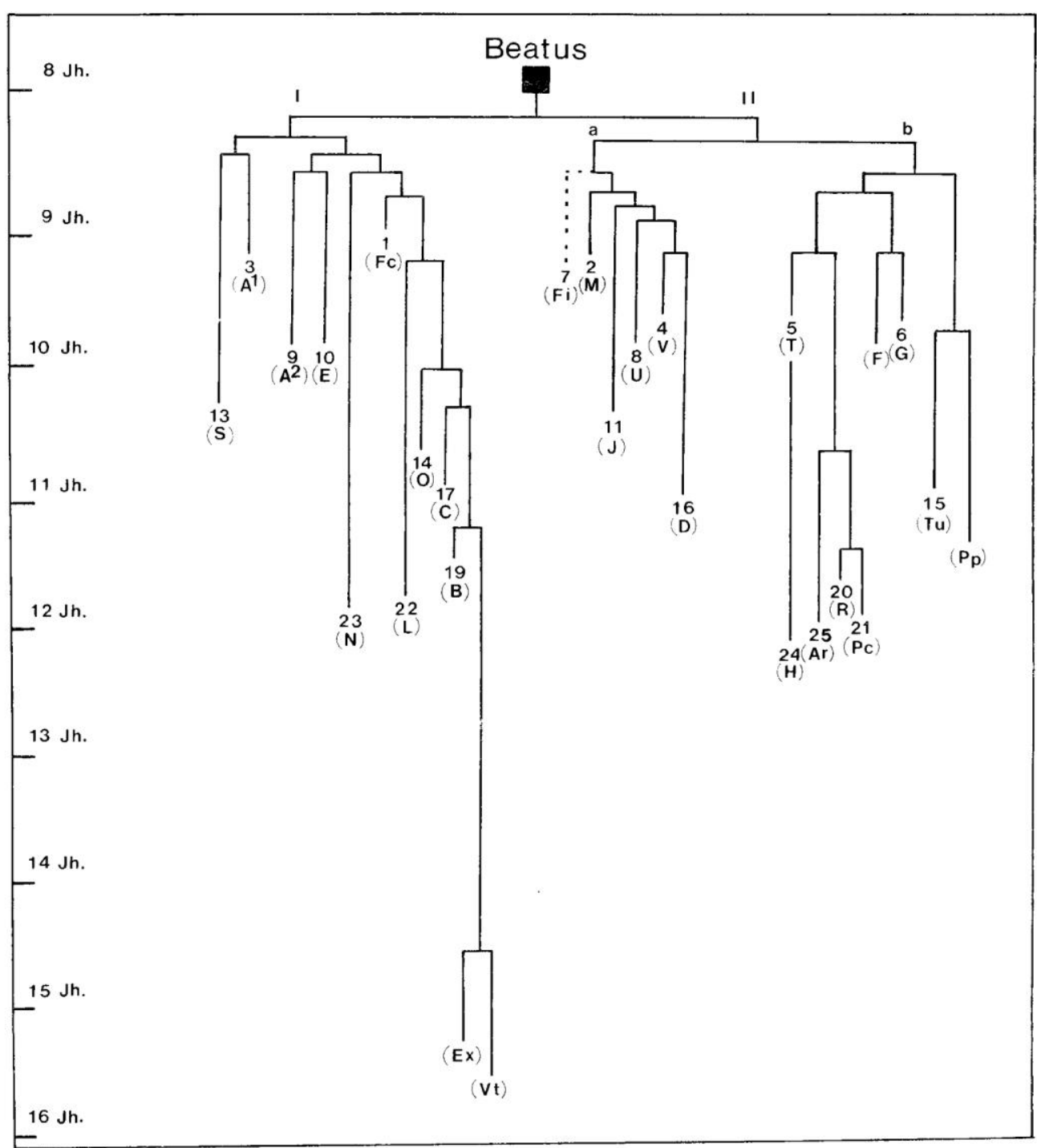

Figura 13. Stemma proposto por Neuss.

Fonte: Williams, $1994^{369}$

369 WILLIAMS, John. The illustrated Beatus: a corpus of the illustrations of the Commentary on the Apocalypse. London: Harvey Miller, 1994, v.1, p. 22. 


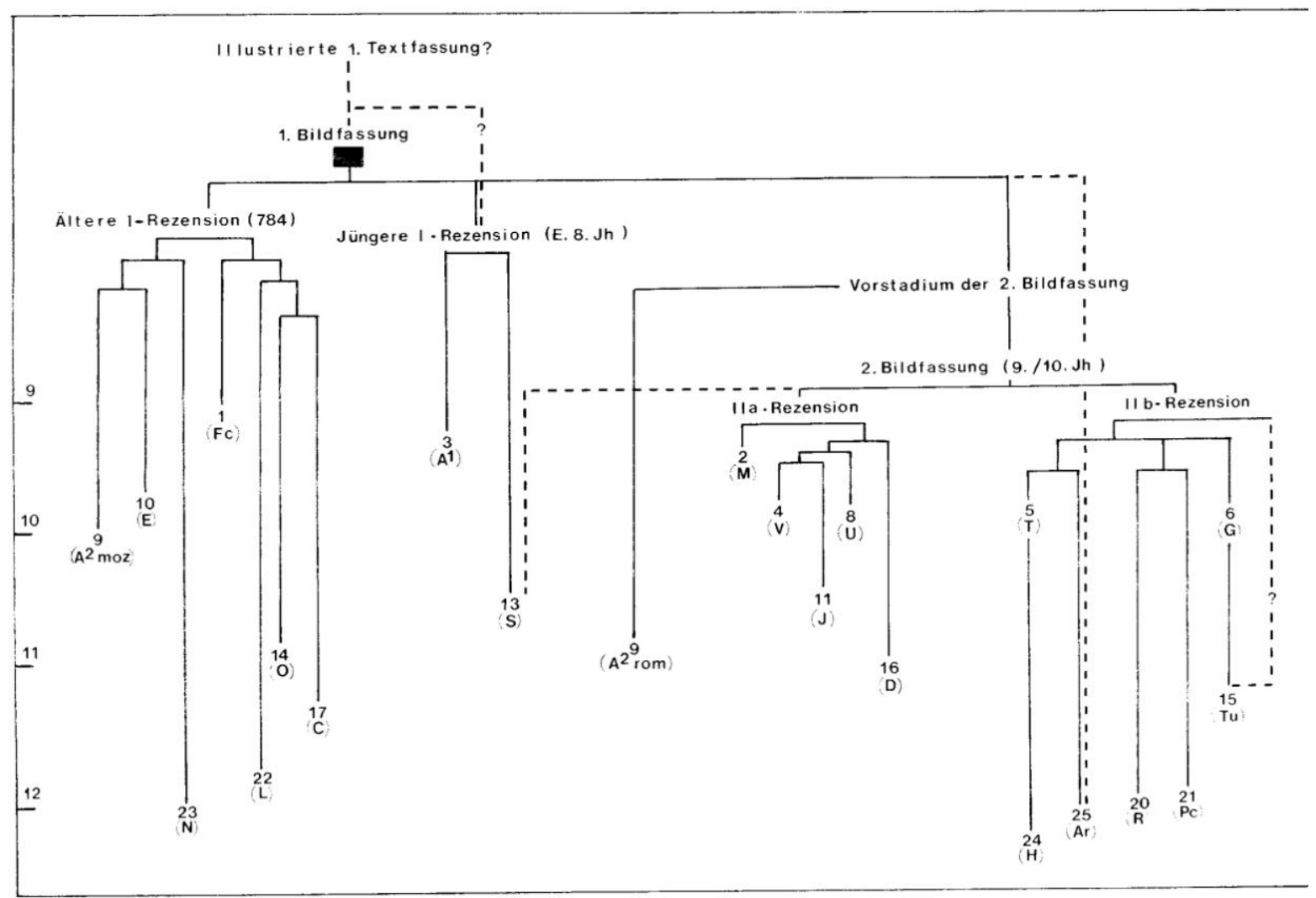

Figura 14. Stemma proposto por Peter Klein.

Fonte: Williams, $1994 .{ }^{370}$

370 WILLIAMS, John. The illustrated Beatus: a corpus of the illustrations of the Commentary on the Apocalypse. London: Harvey Miller, 1994, v. 1, p. 23 


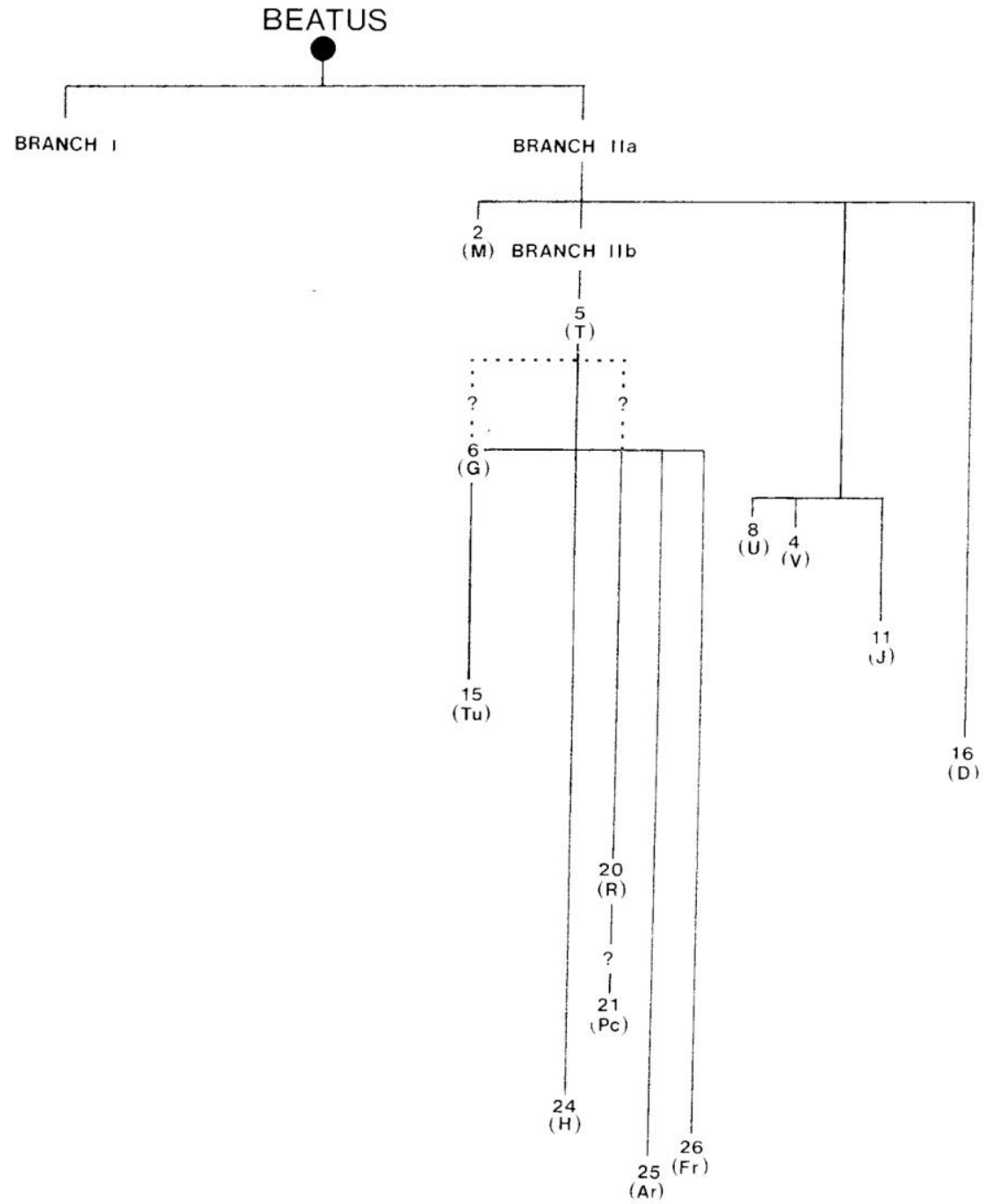

Figura 15. Stemma proposto por John Williams.

Fonte: Williams, $1994 .^{371}$

371 WILLIAMS, John. The illustrated Beatus: a corpus of the illustrations of the Commentary on the Apocalypse. London: Harvey Miller, 1994, v. 1, p. 26. 


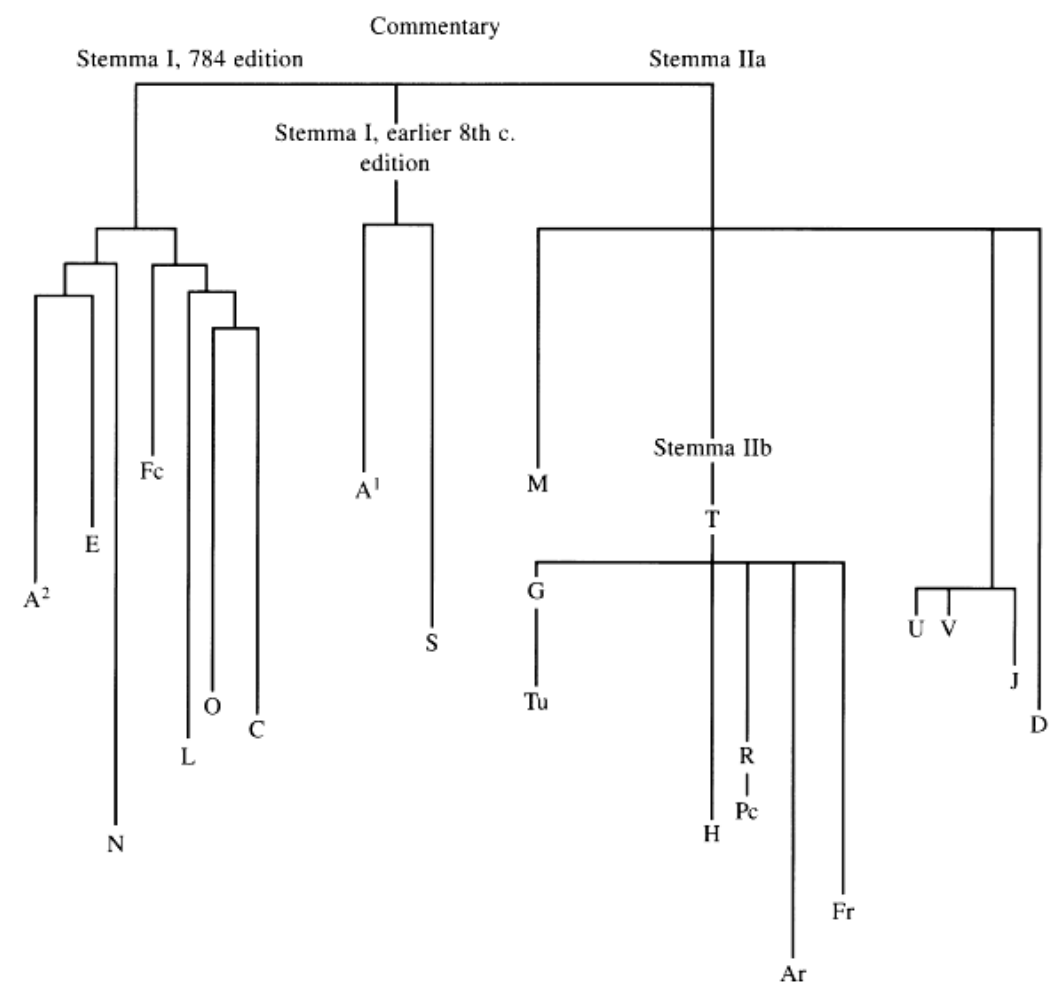

Key:

Stemma I, 784

$\mathrm{A}^{2} \quad$ San Millán

E Escorial

N Navarre

$\mathrm{Fc}$ Silos Fragment

L Lorvão

o Osma

C Corsini

Stemma I, earlier 8th c.

$A^{1}$ Madrid 14-1

S San Sever

Stemma IIa

M Morgan

U Urgell

V Valladolid

J Facundus

D Silos

Stemma IIb

T Tábara

G Girona

Tu Turin

H Las Huelgas

$\mathrm{R}$ Rylands

$\mathrm{Pc}$ Cardeña

Ar Arroyo

Fr Riosecco

Figura 16. Stemma proposto por Bolman.

Fonte: Bolman, 1999. ${ }^{372}$

${ }^{372}$ BOLMAN, Elizabeth S. De coloribus: the meanings of color in Beatus manuscripts. Gesta, vol. $38, \mathrm{n}^{\circ} .1$, p. 22-34, 1999, p. 23. 


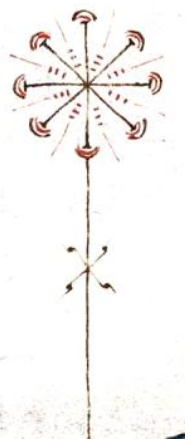

